Karenina Carolina da Silva

\title{
ESTUDO EXPERIMENTAL DE UMA EMENDA DE BARRA PARA CONCRETO ARMADO COM TUBO DE AÇO E GRAUTE
}

Dissertação apresentada à Escola de Engenharia de São Carlos, da Universidade de São Paulo, como parte dos requisitos para obtenção do Título de Mestre em Estruturas.

Orientador: Prof. Tit. Mounir Khalil El Debs

São Carlos

2008 
Ao professor Mounir Khalil El Debs, pela orientação, dedicação e amizade.

A Fernando, que teve grande participação nesta pesquisa, com muitas conversas, ensinamentos, incentivo, e principalmente pela amizade.

Aos meus pais, Ademir e Margarete pela educação dada, o carinho e apoio incondicional.

A toda a minha família, principalmente meus irmãos, Crhistiane, Junior e Yana, que me ajudou incentivando e torcendo para que tudo desse certo.

A Ricardo, pela paciência, amor e conversas.

Aos amigos de Natal, especialmente, Fabiana, Myrian, Renata, Ângela, Glebe e Bruno, que sempre me esperaram, apoiaram e incentivaram, e a Jailson por me esclarecer muitas coisas, companheirismo e ajuda técnica.

Aos amigos que fiz em São Carlos, em especial a Lívia, Iara, Fernanda, Gláucia, Mônica, Alice, Gustavo, Marlos e Eduardo, sem os quais esse mestrado seria possível, mas menos agradável.

Aos amigos natalenses que fiz em São Carlos, Denis, Claudius e principalmente Mariana por toda afinidade e simpatia.

A Érica e sua família que com toda atenção e carinho foram a minha família em São Carlos.

Aos colegas de turma e de departamento com ajuda e companheirismo. 
Aos professores do Departamento de Engenharia de Estruturas de EESC-USP, em espacial ao professor Samuel e Hanai.

Aos funcionários do Departamento de Estruturas da EESC-USP.

A toda a equipe do laboratório de estruturas EESC-USP, em especial Amaury e Romeu.

À empresa BASF pela doação do graute utilizado.

À empresa PROTUBO pela doação dos tubos utilizados.

A CAPES e a FAPESP pelo apoio financeiro concedido.

A todos que de uma forma ou de outra contribuíram não só para a conclusão de mais uma etapa, como tornaram esta fase inesquecível e possível. 


\section{SUMÁRIO}

RESUMO

ABSTRACT.

1 INTRODUÇÃO

1.1 Considerações iniciais

1.2 Objetivos

1.3 Justificativas

1.4 Metodologia

1.5 Apresentação da dissertação

2 REVISÃO BIBLIOGRÁFICA

2.1 Considerações iniciais

2.2 Tipos de emenda de barras

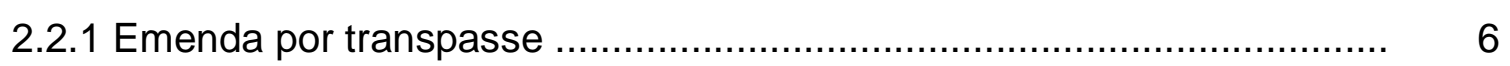

2.2.2 Emenda por solda ........................................................................

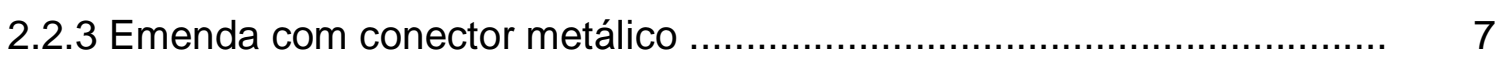

2.2.4 Emenda com tubo preenchido por graute ............................................ 7

2.3 Alguns fatores relevantes no comportamento da emenda estudada ................. 10

2.3.1 Aderência aço-concreto .................................................................. 10

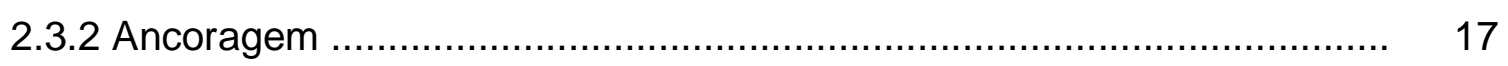

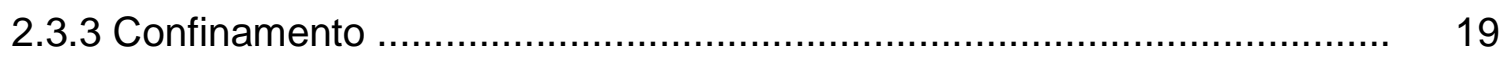

3 PROGRAMA EXPERIMENTAL ……......................................................... 23

3.1 Considerações iniciais ...................................................................... 23

3.2 Definição do graute utilizado ..................................................................... 24

3.3 Caracterização dos materiais .................................................................... 26

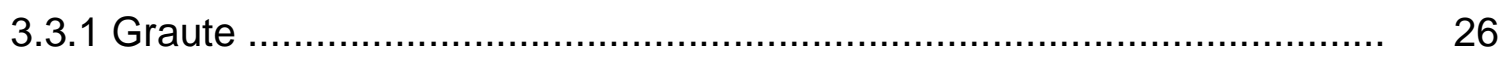

3.3.1.1 Execução da mistura ......................................................... 26

3.3.1.2 Resistência à compressão ....................................................... 27 
3.3.1.3 Resistência à tração ............................................................... 28

3.3.1.4 Módulo de Elasticidade ......................................................... 28

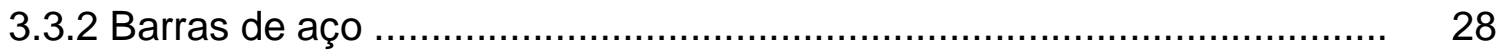

3.3.4 Tubo de aço .................................................................................. 29

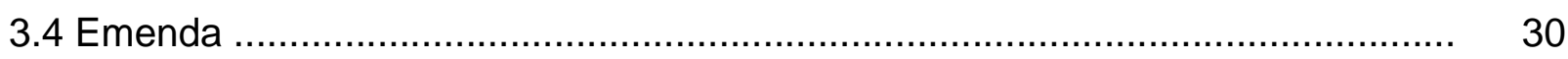

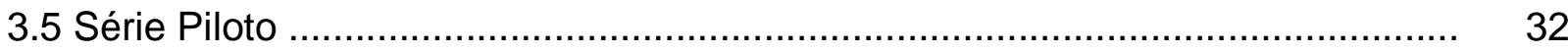

3.5.1 Moldagem das emendas ............................................................. 33

3.5.2 Execução do ensaio ........................................................................... 33

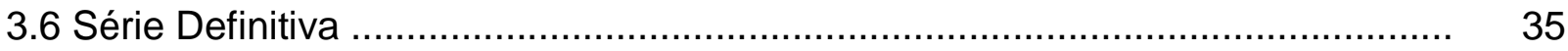

3.6.1 Moldagem das emendas ............................................................ 36

3.6.2 Execução do ensaio ............................................................................. 38

4 APRESENTAÇÃO E ANÁLISE DOS RESULTADOS …….................................. 49

4.1 Definição do graute utilizado .................................................................. 49

4.2 Caracterização do graute e do aço.............................................................. 49

4.3 Parâmetros de cálculo …………............................................................... 51

4.4 Série Piloto ......................................................................................... 52

4.4.1 Resultados das emendas ………................................................... 52

4.4.2 Resumo dos resultados ............................................................ 59

4.4.3 Comparação entre as emendas ………………………………...... 59

4.4.3.1 Influência da corrugação do tubo ........................................... 59

4.4.3.2 Influëncia do diâmetro da barra de aço .................................... $\quad 60$

4.4.3.2.1 Tubos lisos ............................................................ 60

4.4.3.2.2 Tubos corrugados …................................................. 61

4.4.3.3 Influência do posicionamento da barra ..................................... 62

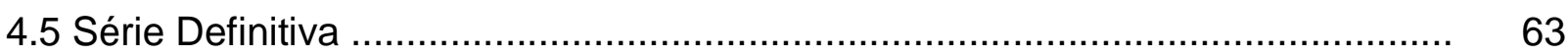

4.5.1 Resultados das emendas da Série 1 ............................................... 63

4.5.2 Resultados das emendas Série 2 ................................................. $\quad 78$

4.5.3 Resultados das emendas da Série 3 ................................................ 84 
4.5.4 Resumo dos resultados

4.5.5 Comparação entre as emendas ............................................... 90

4.5.5.1 Influência do carregamento ................................................... 90

4.5.5.2 Influência do diâmetro da barra .............................................. 91

4.5.5.3 Influência do posicionamento da barra ................................. 91

4.5.5.4 Influência do cobrimento ...................................................... 92

4.5.5.5 Influência do comprimento de ancoragem ............................ 93

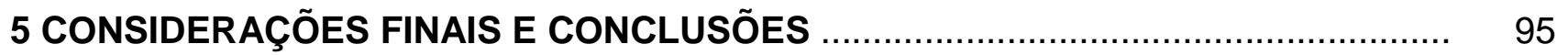

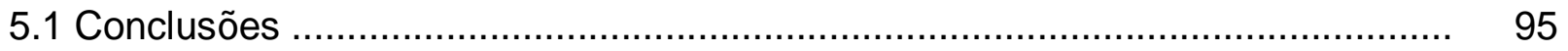

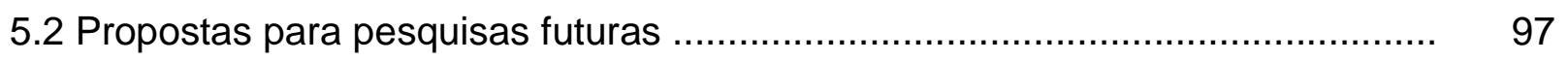

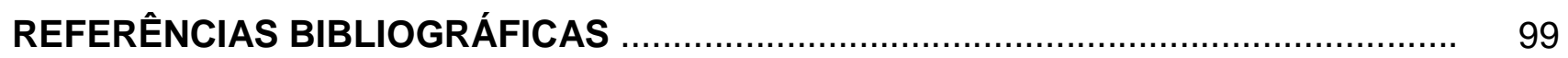




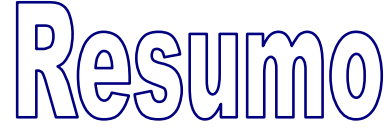

SILVA, K. (2008). Estudo experimental de uma emenda de barra para concreto armado com tubo de aço e graute. Dissertação (Mestrado) - Escola de Engenharia de São Carlos, Universidade de São Paulo, São Carlos. 2008.

Neste trabalho se avaliou experimentalmente o comportamento de um sistema de emenda de barra que transmitisse de forma mais eficiente os esforços solicitantes. A emenda consistiu-se de um tubo de aço preenchido com graute de alta resistência à compressão e duas barras de aço, uma em cada extremidade com o mesmo comprimento de embutimento. Esta emenda foi submetida a ações monotônicas e cíclicas de tração axial, com controle de deslocamento até atingir a ruptura, verificando a capacidade última da emenda e seus modos de ruína. No programa experimental foram ensaiadas emendas sendo que foram levados em consideração os seguintes parâmetros: o diâmetro da barra, o diâmetro do tubo, a conformação superficial do tubo, o tipo de carregamento, o cobrimento, o comprimento de embutimento e a posição da barra. A ruptura das emendas ocorreu por escoamento da barra de aço, fendilhamento e escorregamento da barra em relação ao graute; conforme o diâmetro da barra e a conformação superficial interna do tubo. Ainda, verificou-se que este tipo de emenda garante uma adequada transferência de esforços de tração. A corrugação do tubo teve influência significativa, uma vez que a sua falta levou ao escorregamento da barra em relação ao graute, bem como o comprimento de embutimento insuficiente levou à ruptura do graute; a posição da barra não teve influência significativa.

Key-words: emenda, ensaios, aderência, ligação grauteada 
SILVA, K. (2008). Experimental study of a splicing system with a grout-filled steel tube and reinforced bar. Dissertation - Escola de Engenharia de São Carlos, Universidade de São Paulo, São Carlos. 2008.

The main purpose of this research was to analyze experimentally the behavior of a splicing system with a grout-filled steel tube and reinforced bar to transmit the efforts efficiently. A splice was prepared with a grout-filled steel tube and two reinforced bars, one in each end of the tube with the same anchorage length. The splices were loaded in monotonic and ciclic axial tension until failure, with displacements control, measuring the maximum load and observing the splicing failure mode. An experimental program was carried out and adopted as variables the bar diameter, the tube diameter, the type of internal surface of the tube, the loading, coverage, lenght anchorage and the bar position. The failure of the splice occurred by yielding bar failure, grout splitting and grout slipping, according to the bar diameter and the internal surface of the tube. It was verified that this type of splice guarantees a good efforts transmission. The ribs inside the tube had significant influence, while the failure occurred by the grout slipping without the tube ribbed; the bar position had not significant influence

Key-words: splice, tests, bond, grouted joints 

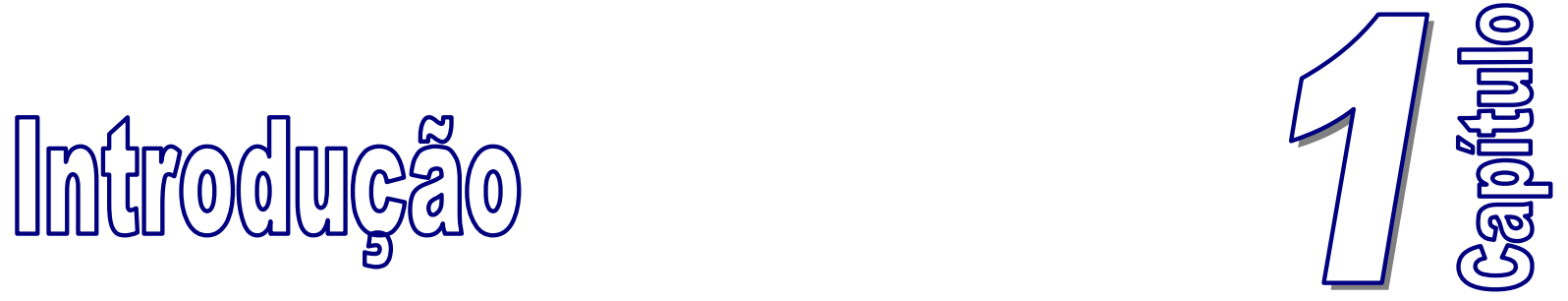

\subsection{Considerações Iniciais}

A indústria da pré-moldagem enfrenta limitações para seu uso e viabilização plena, dentre as quais a necessidade de se promover ligações entre os vários elementos que compõem a estrutura. Por isso, as ligações entre os elementos prémoldados é a principal dificuldade para sua utilização em relação ao concreto moldado no local, isto porque ligações mais simples, normalmente articulações, proporcionam pouca capacidade de distribuição dos esforços solicitantes. Enquanto que ligações que possibilitam a transmissão de momentos fletores, denominadas rígidas, são mais onerosas, mais complicadas de serem executadas e muitas vezes acarretam em demora na construção da estrutura.

É necessário muito cuidado e atenção no projeto e detalhamento das ligações, pois são regiões de descontinuidade dos elementos e onde as tensões ficam concentradas.

Para que seja desenvolvido um bom projeto, as ligações devem combinar economia e praticidade, atendendo às necessidades de ductilidade, durabilidade, resistência e rigidez. O ideal seria uma ligação que transmitisse os esforços solicitantes totalmente, diminuindo assim as seções resistentes das peças e, consequentemente, diminuindo o consumo de materiais e aumentando a área útil. Portanto, uma ligação barata e de fácil execução, representada nas técnicas da prémoldagem. 
Para se desenvolver emendas que transmitam momento fletor é necessário fazer a ligação da armadura, o que recai na necessidade de emenda de barras.

Neste trabalho é estudada uma emenda de barra que foi desenvolvida para fazer parte de uma ligação viga-pilar. A emenda estudada é constituída por um tubo de aço, graute e barra de aço. A barra de aço é grauteada no tubo de aço que está embutido na viga.

Embora a emenda tenha sido concebida para ligações de concreto prémoldado, ela pode ser utilizada para concreto moldado no local também, o que não limita a abrangência deste estudo.

\subsection{Objetivos}

Este trabalho tem como objetivo geral o estudo experimental de uma emenda com graute, tubo de aço e barra de aço e como objetivos específicos, têm-se:

- Verificar os tipos de ruína da emenda e a sua resistência última;

- Avaliar as principais variáveis envolvidas no seu comportamento;

- Investigar a exeqüibilidade desta emenda de barra de aço com preenchimento de graute.

\subsection{Justificativas}

Apesar da variedade de tipos de ligações viga-pilar, há a necessidade de se estudar uma nova ligação capaz de transmitir os esforços solicitantes de modo integral e com menor custo.

Há muito estudo sobre este tipo de ligação, mas poucos trabalhos relacionados ao assunto específico emenda, que é o objetivo principal de estudo desta pesquisa. Além disso, existem poucos resultados experimentais.

Um estudo teórico-experimental desta emenda torna-se necessário, contribuindo para o meio acadêmico com uma solução e explicação mais realística do problema e para o meio técnico com subsídios para um dimensionamento adequado que atenda aos critérios de economia e segurança. 


\subsection{Metodologia}

A metodologia empregada no desenvolvimento dessa pesquisa foi basicamente uma investigação experimental dos protótipos definidos.

Foram levantadas variáveis consideradas nos ensaios preliminares, permitindo um planejamento sistemático dos ensaios da etapa seguinte.

Com base nos ensaios experimentais, um detalhamento mais adequado e racional da emenda com tubo de aço, graute e barra de aço foi proposto. A influência de força cíclica foi simplificadamente analisada, pois esse tipo de ação ocasiona uma diminuição na aderência entre o aço e o concreto, que é um fator muito importante para o desempenho desta emenda.

Foi feito um ensaio piloto para avaliar o desempenho da emenda e a partir dos resultados fizeram-se as alterações para adequar o modelo.

\subsection{Apresentação da dissertação}

No capítulo 1 é feita uma abordagem sobre ligações em elementos prémoldados e uma explanação da emenda estudada, listando os objetivos e justificativas deste trabalho, além da metodologia empregada.

No capítulo 2 é realizada uma revisão bibliográfica sobre emendas de barra, apresentando alguns tipos de classificação e os principais elementos que formam a emenda em estudo e a influência deles no comportamento da mesma. Por fim, são apresentados os principais estudos encontrados na literatura.

No capítulo 3 são descritos todos os aspectos relativos à análise experimental, como: análise dos materiais, metodologia empregada nos ensaios, instrumentação utilizada e preparação dos modelos para os ensaios.

No capítulo 4 apresentam-se os resultados do programa experimental e sua análise.

No capítulo 5 são apresentadas as conclusões deste trabalho, bem como sugestões para trabalhos futuros. 

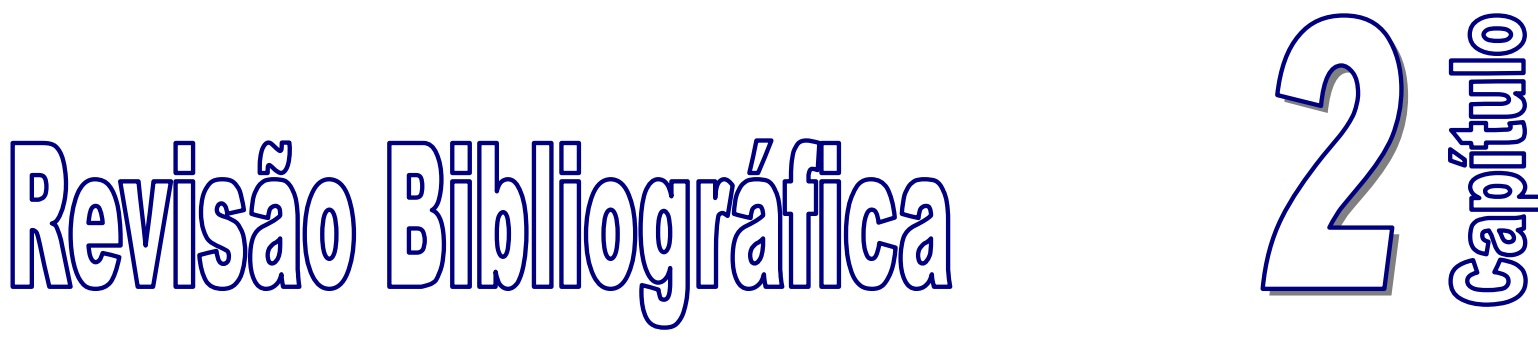

Neste capítulo é feita uma breve explanação sobre emenda de barras tracionadas, seus tipos e os vários fatores que interferem no seu comportamento como o efeito da aderência aço-concreto, ancoragem e confinamento.

\subsection{Considerações iniciais}

O objeto de estudo desta pesquisa é uma emenda, que pode fazer parte de uma ligação viga-pilar (Figura 2.1), para transmissão dos esforços solicitantes em elementos prémoldados. Ela é uma emenda constituída por uma barra de aço, um tubo de aço e graute, conforme pode ser visto na Figura 2.2.
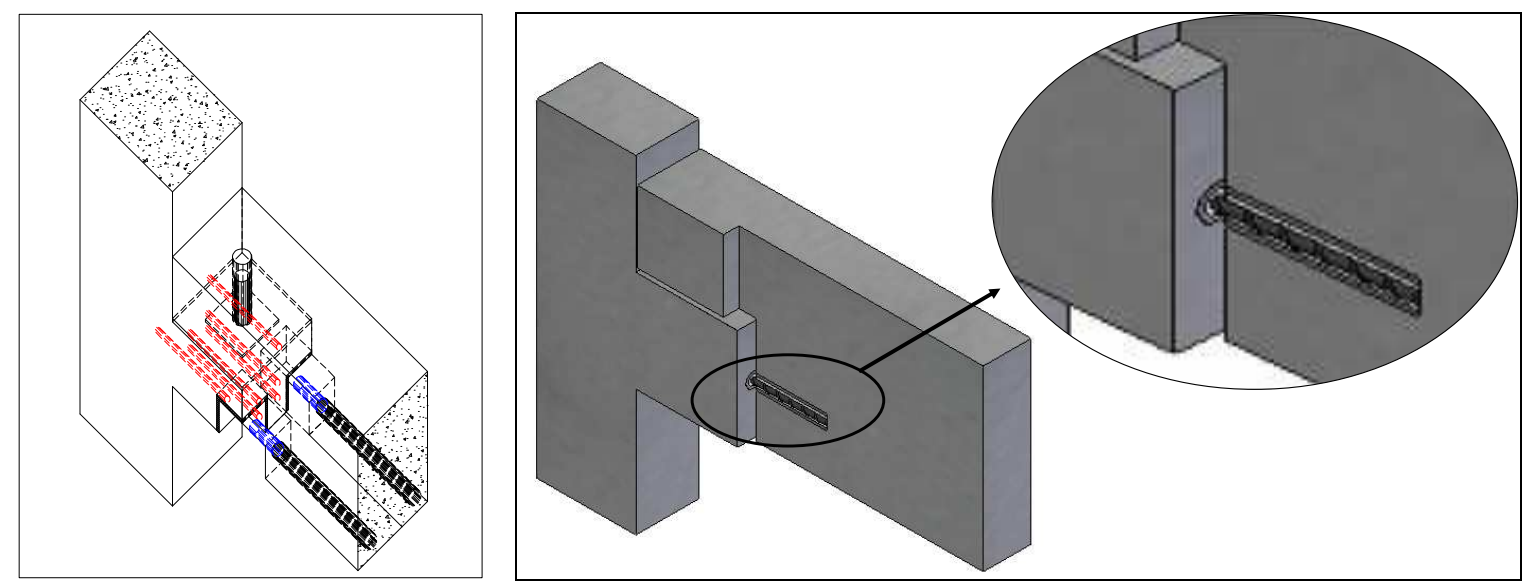

Figura 2.1 - Ligação viga-pilar com detalhe da emenda estudada 


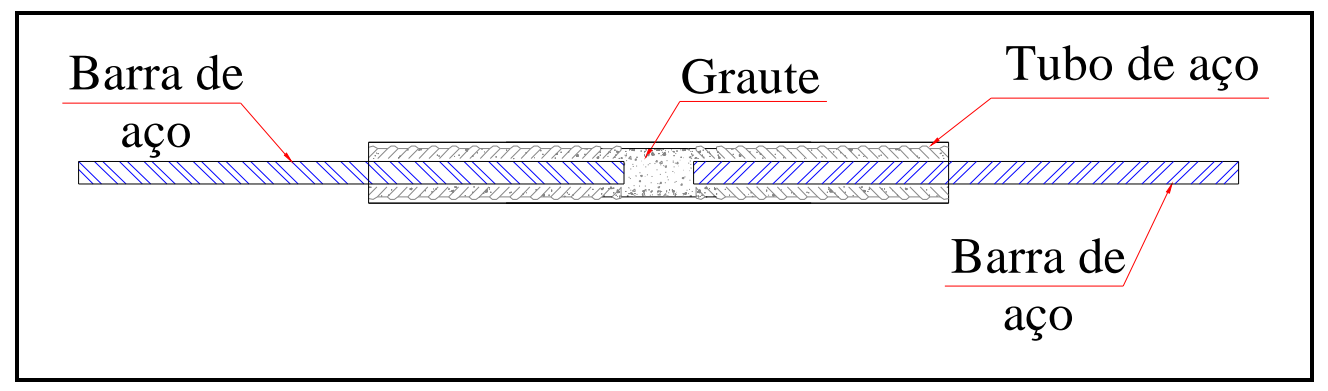

Figura 2.2 - Emenda estudada

A problemática da ligação viga-pilar recai na transmissão de momento fletor, sendo necessária a emenda de barras, com comprimento limitado e acomodando as tolerâncias de execução e montagem.

\subsection{Tipos de emenda de barras}

Emenda é o ato ou efeito de juntar uma peça a outra. Para isso, a aderência entre o aço e o graute é um fator muito importante, pois a força é transmitida do tubo de aço, ao graute e do graute à barra de aço, neste caso estudado. E as nervuras, tanto do tubo quanto da barra, têm grande influência na aderência.

Há variados tipos de emenda, sendo as mais importantes a emenda por transpasse; emenda com solda; emenda com conector metálico e a emenda com tubo preenchido por graute.

\subsubsection{Emenda por transpasse}

As emendas por transpasse (Figura 2.3) não são permitidas em barras de bitola superior a $25 \mathrm{~mm}$, tirantes e pendurais. As barras lisas tracionadas devem conter ganchos e em barras tracionadas devem ser evitadas em regiões de altos momentos.

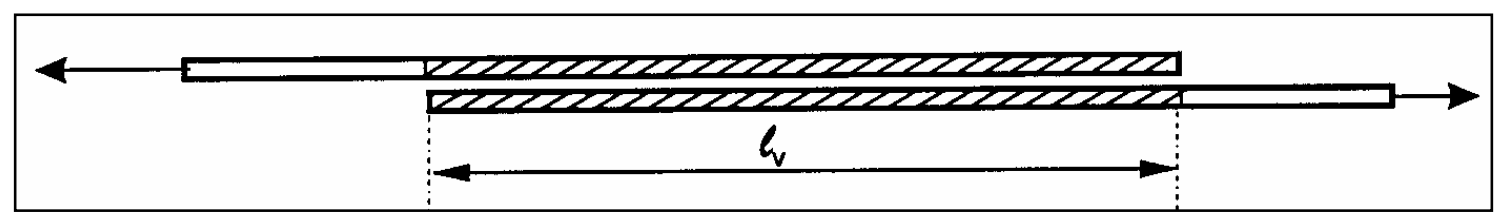

Figura 2.3 - Emenda por transpasse 


\subsubsection{Emenda por solda}

As emendas soldadas podem ser executadas como emenda de topo, como emenda por transpasse ou como emenda com cobre-juntas. Sendo preferencialmente usada a solda do tipo autógena por pressão (Figura 2.4).

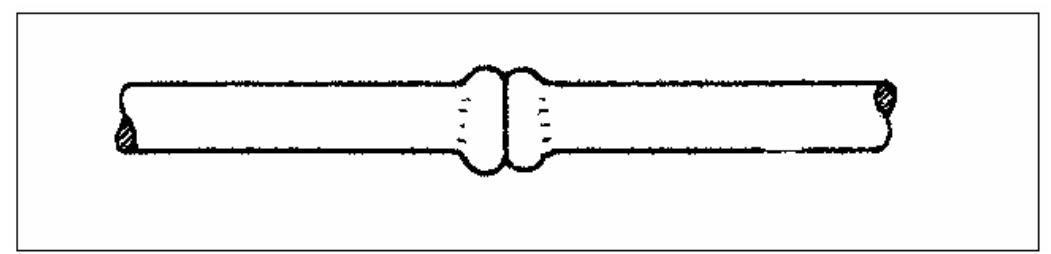

Figura 2.4 - Emenda de topo com solda autógena por pressão (Leonhardt, 1978)

\subsubsection{Emenda com conector metálico}

O mais importante benefício de se utilizar emenda com conector metálico (Figura 2.5) é a garantia da continuidade da transmissão das forças na armadura principal independente da condição do concreto existente. Emendas mecânicas mantêm a integridade estrutural quando as barras são tensionadas. Na emenda rosqueada há diminuição da transmissão dos esforços solicitantes.

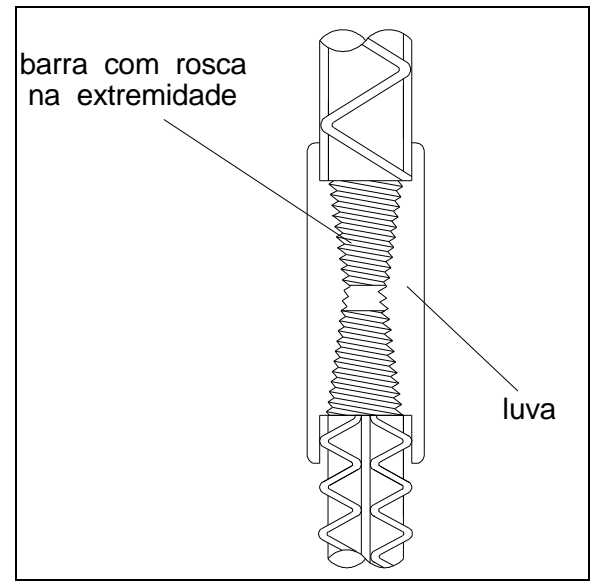

Figura 2.5 - Emenda com conector metálico( El Debs, 2000)

As vantagens econômicas e estruturais das emendas mecânicas fazem com que a relação custo-benefício seja extremamente atrativa. As emendas mecânicas dão à estrutura um acréscimo de tenacidade e continuidade no caminho dos esforços solicitantes que o transpasse não pode oferecer.

\subsubsection{Emenda com tubo preenchido por graute}

Neste tipo de emenda indireta, é necessário que o concreto participe, pois a força é 
transmitida de um elemento a outro por aderência ou por esforços em virtude da mudança de direção da barra, por meio de bielas inclinadas de compressão (Figura 2.6).

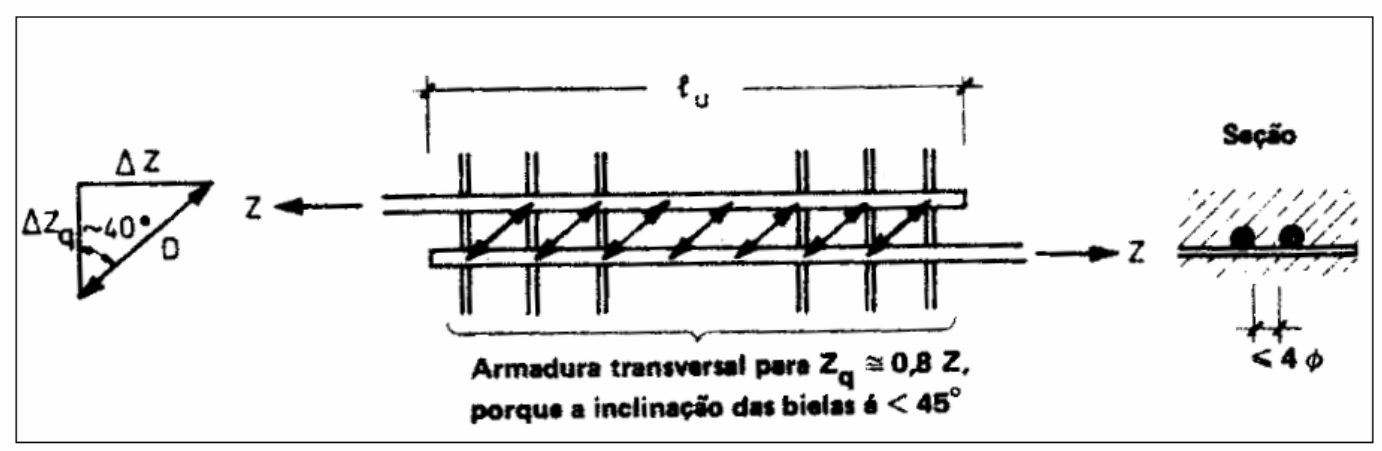

Figura 2.6 - Bielas inclinadas de compressão ( Leonhardt, 1978 )

Zheng (1996) estudou uma ligação entre pilares formada pelo grauteamento de barras de espera extendidas de uma unidade de pilar aos dutos de outra unidade (Figura 2.7) submetida a ações cíclicas combinadas com forças de compressão axial. Para se estimar a capacidade resistente dessa ligação pôde ser utilizada a teoria convencional de concreto armado, como se fosse uma estrutura monolítica. O grauteamento permitiu a ancoragem total das barras de espera. Os ciclos de momentos fletores causaram redução progressiva da rigidez apenas quando a intensidade do momento estava acima de um valor crítico. Constatou-se que esse tipo de ligação é apropriado para suportar ações cíclicas e alternadas.

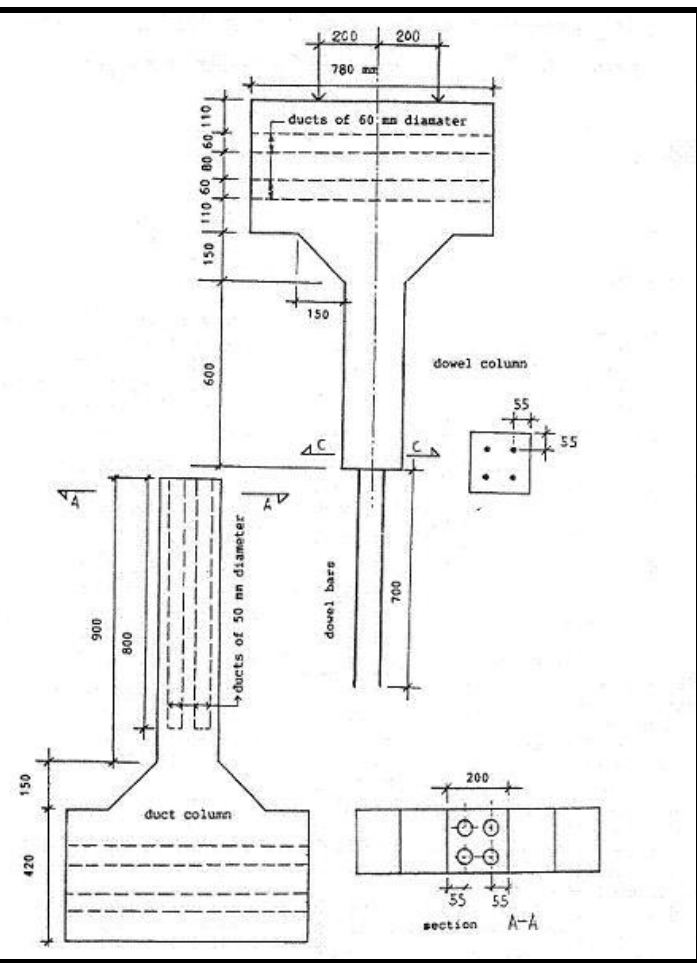

Figura 2.7 - Dimensões do modelo de ligação entre pilares (Zheng, 1996) 
Lohaus e Anders (2006) analisaram o comportamento de ligações de barras grauteadas em pilares (Figura 2.8) submetidas a forças de compressão uniaxial estáticas e dinâmicas e à fadiga. Para aumentar a capacidade resistente de força axial última foram feitas chaves de cisalhamento, que com o aumento da sua altura, até um certo limite, conseguiu-se um aumento da resistência.

Um aspecto importante sobre o comportamento das ligações grauteadas é o seu modo de ruína, que pode ser por cisalhamento ao longo das chaves de cisalhamento ou ruptura da matriz de graute.

A Figura 2.9 mostra que a altura da chave de cisalhamento não é o único parâmetro a afetar a resistência de aderência última. Na Figura $2.9 a$ observa-se que o grande espaçamento entre as chaves de cisalhamento causa ruptura da matriz do graute; a Figura 2.9b apresenta uma razão ótima entre a altura e o espaçamento das chaves de cisalhamento; e a Figura 2.9c apresenta pequeno espaçamento entre as chaves de cisalhamento e uma conseqüente ruína por cisalhamento ao longo das chaves de cisalhamento, mostrando que o espaçamento entre as chaves também deve ser considerado, pois, quando o espaçamento entre as chaves de cisalhamento diminuía a um valor crítico, a superfície de aço se comporta como um tubo liso. Esta é uma das razões pela regulamentação do limite da razão entre a altura da chave de cisalhamento e o seu espaçamento. Com o aumento da altura da chave de cisalhamento, a resistência à compressão do graute se torna um fator limitante para a força última. Pois, de acordo com a forma da ligação grauteada, toda a força tem que ser transferida pelo graute.

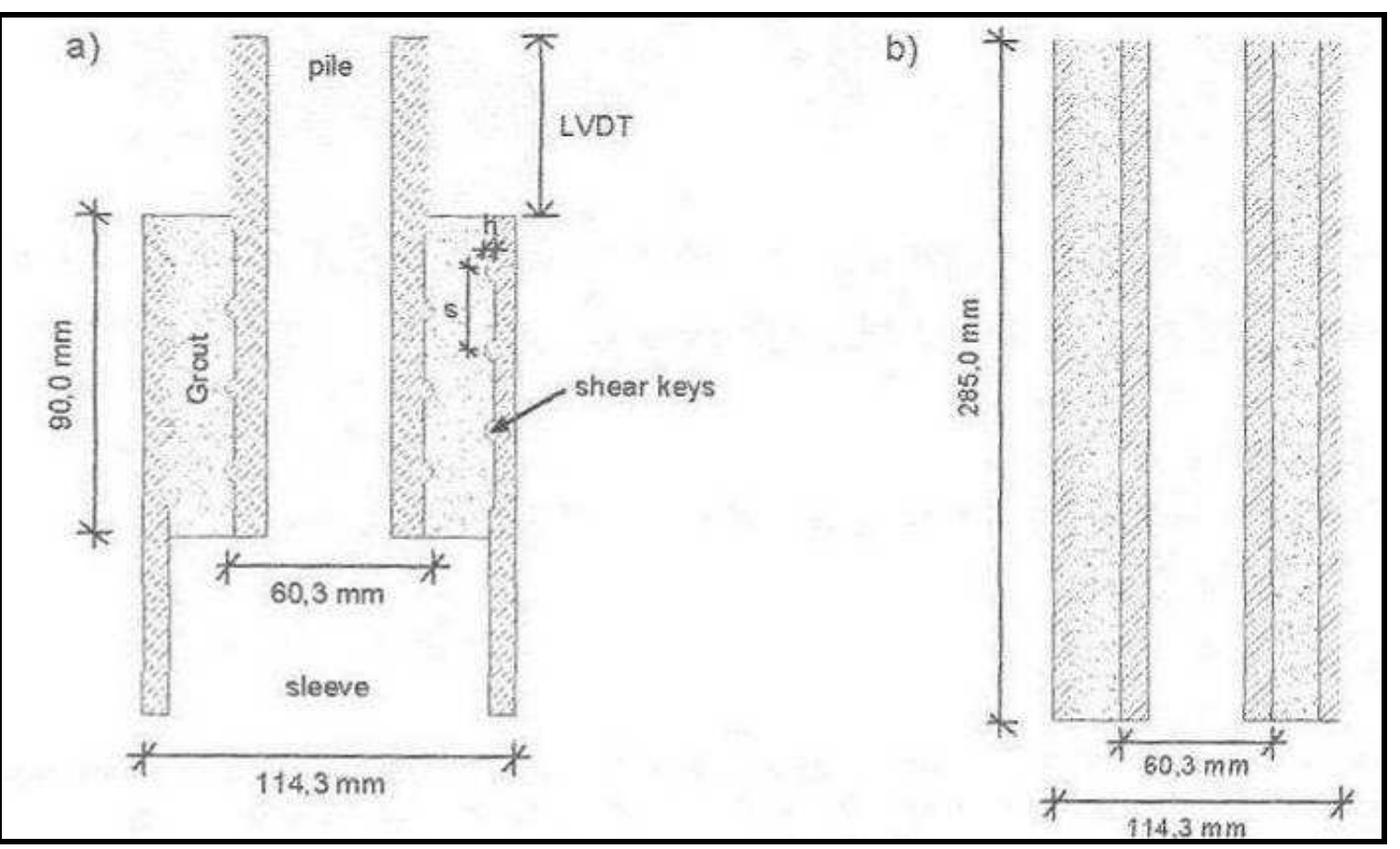

Figura 2.8 - Modelo de ligação grauteada utilizando tubos de aço ( Lohaus e Anders, 2006 ) 


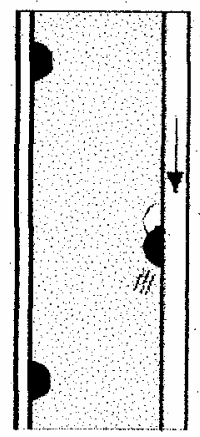

a)

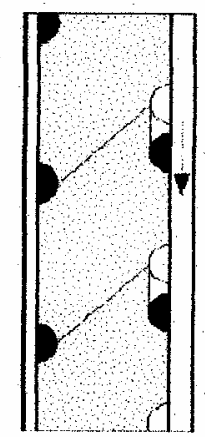

b)

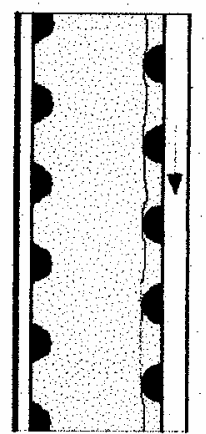

c)

Figura 2.9 - Modos de ruptura em ligações grauteadas (Lohaus e Anders (2006))

Vários modelos com chaves de cisalhamento exibiram curvas bilineares de tensãodeformação na compressão axial. Essas curvas lineares separam dois mecanismos diferentes de carregamento, o que também pode ser identificado no ensaio de fadiga. No caso da fadiga a rigidez observada para ambos mecanismos de carga é similar a rigidez da primeira parte dos ensaios estáticos. Já a rigidez observada na segunda parte linear nos ensaios estáticos é aproximadamente um décimo do valor inicial. Além disso, os ensaios dinâmicos mostraram que a ligação grauteada parece suportar mais à ruptura quando submetida a carregamentos cíclicos do que o graute isoladamente.

\subsection{Alguns fatores relevantes no comportamento da emenda estudada}

Nesta seção é feita uma sucinta análise dos fatores aos quais a emenda estudada é submetida e influenciam no seu comportamento.

\subsubsection{Aderência aço-concreto}

A solidariedade entre os materiais constituintes de uma ligação, neste caso a barra de aço, o graute e o tubo, ou seja, a aderência impede que haja deslizamento relativo entre os elementos, sendo responsável pela transferência das tensões e pela compatibilidade das deformações entre os materiais. Essa transferência de forças de tração é dada ao longo da interface concreto/aço por meio de tensões de aderência que não são uniformemente distribuídas, por causa do escorregamento em pontos da barra, mas que para efeito de cálculo são consideradas uniformes. 
Para garantir a segurança de sistemas estruturais sob condições de ações severas é importante evitar o escorregamento de barras de aço em locais críticos da estrutura.

O conhecimento do comportamento da aderência é essencial para se estabelecerem regras de cálculo de ancoragens e emendas por transpasse das barras da armadura, para cálculo dos deslizamentos considerando a contribuição do concreto tracionado, para controle da abertura das fissuras e, portanto, para o cálculo da quantidade mínima de armadura.

A relação tensão de aderência versus deslizamento tradicionalmente é utilizada para se quantificar a eficiência da ligação aço-concreto. Essa relação está associada ao deslizamento relativo entre a barra da armadura e o concreto que a envolve, e representa a variação da tensão na interface do aço com o concreto.

Segundo Fusco (1976), as nervuras são elementos descontínuos de ligação. Entretanto, em virtude de seu grande número e seu pequeno afastamento relativo, tudo se passa como se houvesse ligação contínua com características melhoradas. Essas nervuras são indispensáveis para que se possam aproveitar as resistências mais elevadas do aço, assegurando uma ligação aço-concreto mais efetiva e confiável. Entretanto, a eficácia das barras nervuradas é maior em relação ao problema de ancoragem que em relação à fissuração.

Segundo o Boletim do CEB 151 (1982), nas barras nervuradas a força de tração é transferida ao concreto pelas nervuras. A componente radial da força nas nervuras, que se difunde perpendicularmente ao eixo da barra no concreto, aumenta com o aumento da tensão de aderência .que é igual à componente longitudinal da força de tração nas nervuras. A força resultante forma um ângulo a com a direção do eixo da barra. A Figura 2.10 mostra um esquema das forças entre a barra e o concreto circunvizinho.

O valor do ângulo a depende do valor do módulo de elasticidade da barra, da resistência ao cisalhamento do concreto no local das microfissuras e da conformação superficial da barra. A componente radial da tensão de aderência é equilibrada com a tensão de tração desenvolvida no concreto circunvizinho (Figura 2.11).

Se o confinamento da barra não é adequado e o valor da tensão de tração no arco excede a resistência à tração do concreto, fissuras de fendilhamento vão se desenvolver ao longo do comprimento da barra. Quando as fissuras de fendilhamento propagam-se em todo o cobrimento, o deslizamento entre a barra e o concreto aumenta consideravelmente, resultando na distribuição uniforme da tensão de aderência ao longo do comprimento de ancoragem (Tepfers e Karlsson, 1997, apud FIB 9.3 TG, 2003). A força de aderência radial é agora resistida pela resistência de tração do concreto circunvizinho. 


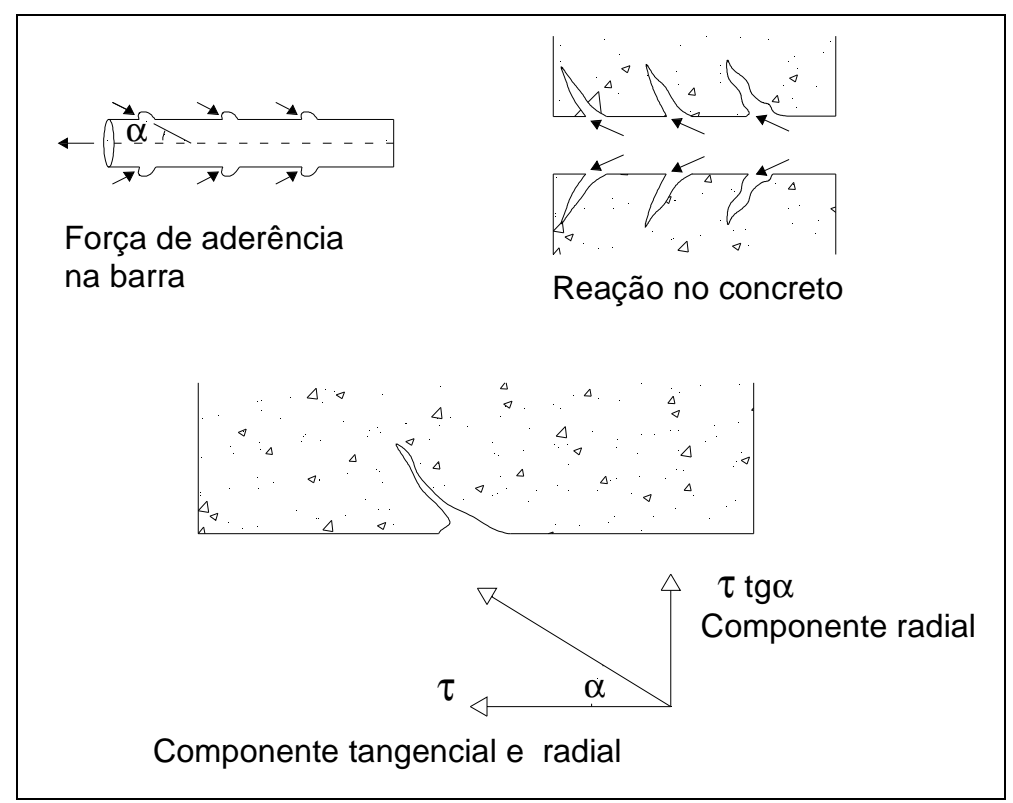

Figura 2.10 - Esquema das forças atuantes entre a barra nervurada e o concreto circunvizinho (CEB 151, 1982)

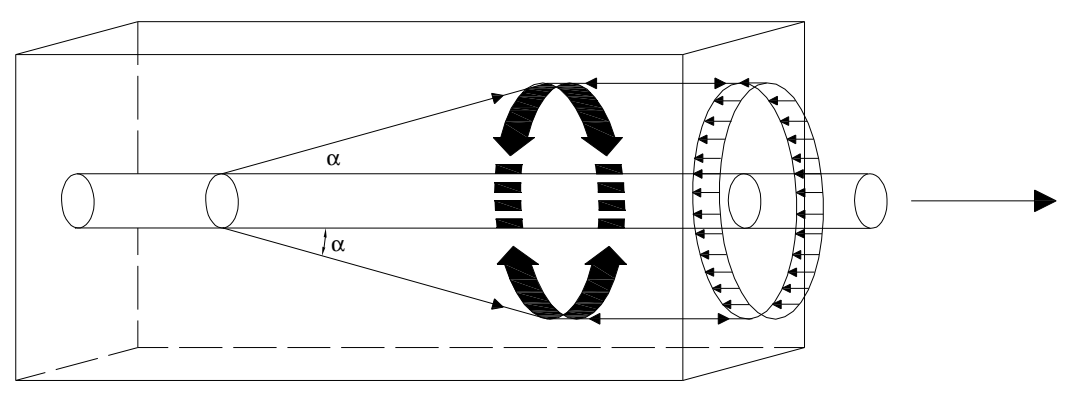

Figura 2.11 - Representação esquemática da componente radial da força de aderência equilibrada diante do anel de tensão de tração no concreto na zona de ancoragem (Tepfers, 1979)

O modo de fissuração é determinado pela geometria da seção transversal do elemento estrutural de concreto e depende da localização da fissura (Figura 2.12).

Se o concreto circunvizinho resistir ao fendilhamento, como por exemplo, no caso de pequenos comprimentos de embutimento em ensaios de arrancamento em cubo de concreto, então, a resistência de aderência pode ser a máxima. Neste estágio, ambas as extremidades da barra deslizam e a resistência da aderência é significativamente diminuída.

Depois de atingida a máxima tensão de aderência, o mecanismo de resistência entre as deformações da barra e os consolos de concreto deixa de funcionar e a tensão de aderência decresce consideravelmente. A resistência de aderência residual depende da resistência de atrito e da interface de ruína. A rugosidade da interface de ruína determina a magnitude de aderência residual. 
Em ligações de elementos estruturais submetidos a terremotos é muito importante ancorar adequadamente as barras num núcleo confinado. $O$ fator chave que governa o comportamento de uma barra ancorada num concreto confinado é a relação tensãodeformação da aderência localizada.

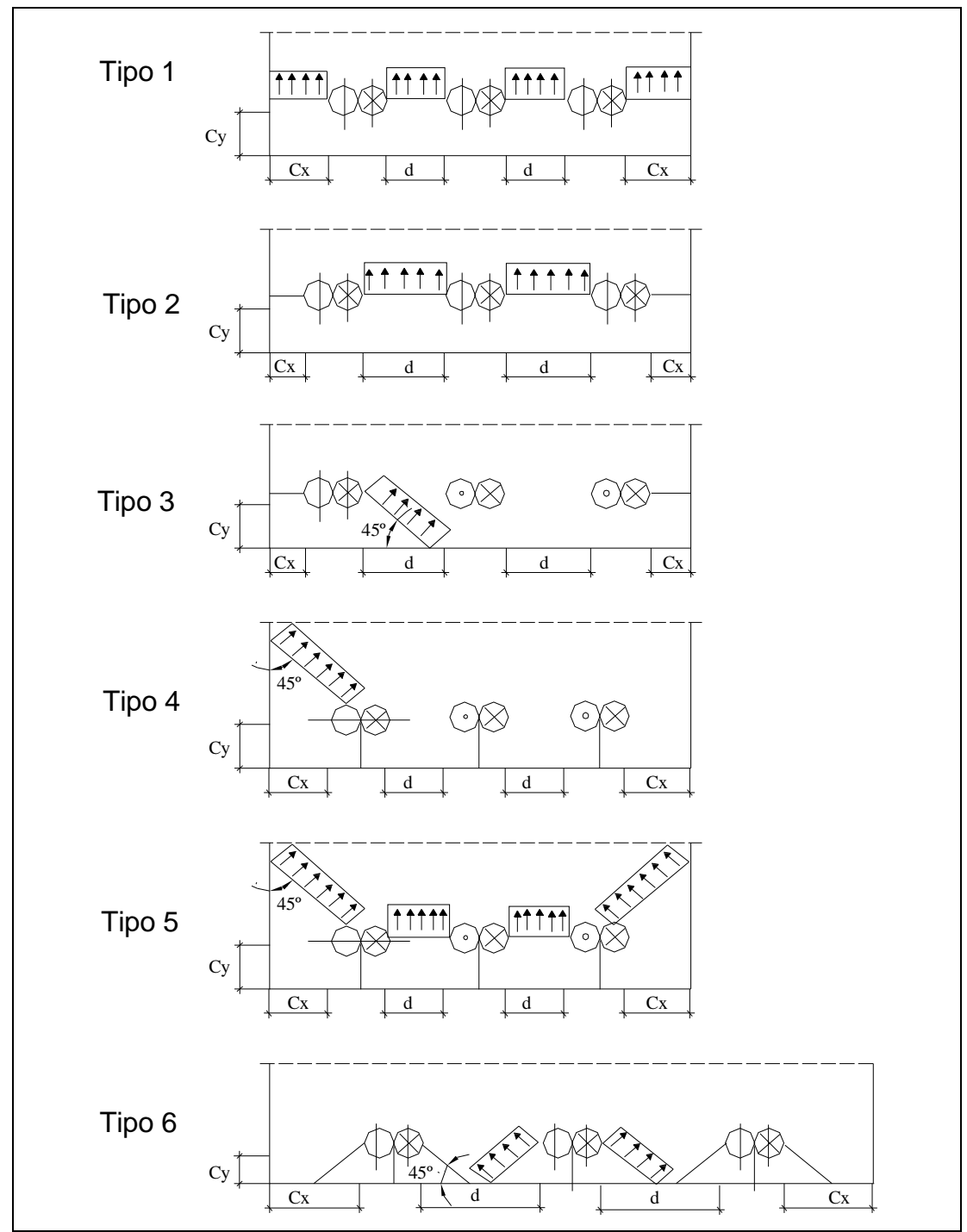

Figura 2.12 - Possíveis formas de ruína por fendilhamento, no concreto circunvizinho (Tepfers, 1973)

Em estudo feito por Soroushian e Choi (1989), foi analisada a influência do diâmetro da barra de aço neste tipo de ligação. Os resultados foram usados para avaliar os efeitos do diâmetro da barra na ancoragem em relação à resistência de ruptura e à relação tensãodeformação da ligação com concreto confinado, e com isso um modelo de ligação empírico 
foi proposto contabilizando esses efeitos. A Figura 2.13 mostra o pico da resistência de aderência que diminui com o aumento do diâmetro da barra.

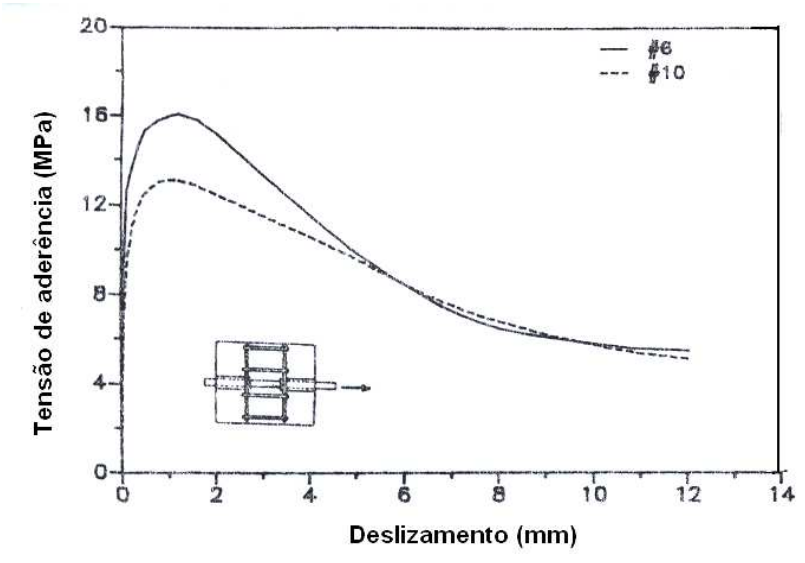

Figura 2.13 - Relações tensão de aderência-deslizamento para barras de diferentes diâmetros(Soroushian e Choi, 1989)

Análises de dados experimentais e analíticos permitem o projeto de barras ancoradas em ligações viga-pilar, controlando seu descolamento e arrancamento sob condições severas de excitação sísmica.

No interior das ligações, as barras de ancoragem são encaixadas no concreto confinado. A armadura de confinamento evita a propagação e a abertura das fissuras de fendilhamento. Essas fissuras são causadas por tensões radiais e tendem a se propagar na direção normal ao eixo longitudinal do pilar. As barras longitudinais têm um importante papel para impedir essas fissuras de fendilhamento e a ruptura geralmente ocorre pelo escorregamento das barras de ancoragem, num processo que envolve: (1) início de fissuras inclinadas sob tensão tangencial nas nervuras (Figura 2.14), (2) esmagamento e fissura de cisalhamento nas chaves de concreto entre as nervuras (Figura 2.15) e (3) descolamento de grandes partes das chaves de concreto entre as nervuras, levando a um completo descolamento das chaves (Figura 2.16). Depois disso, o arrancamento da barra é resistido apenas por forças de atrito. É acentuada a importância de que um gradual descolamento das chaves de concreto e um eventual arrancamento da barra sejam possíveis apenas pelo fato de que o aço confinado evite um crescimento excessivo das fissuras de fendilhamento.

Constata-se que o comportamento da aderência localizada no concreto confinado é influenciado por fatores como a resistência à compressão do concreto, diâmetro da barra de ancoragem, conformação superficial da barra e espaçamento. Sendo que há informação limitada disponível sobre os efeitos do diâmetro da barra no comportamento da aderência local com concreto confinado. 


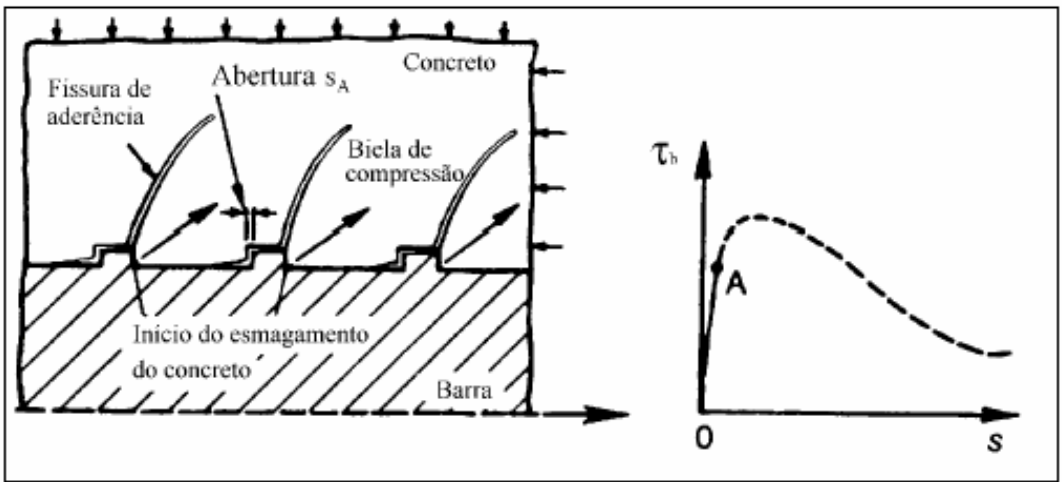

Figura 2.14 - Início das fissuras (Soroushian e Choi, 1989)

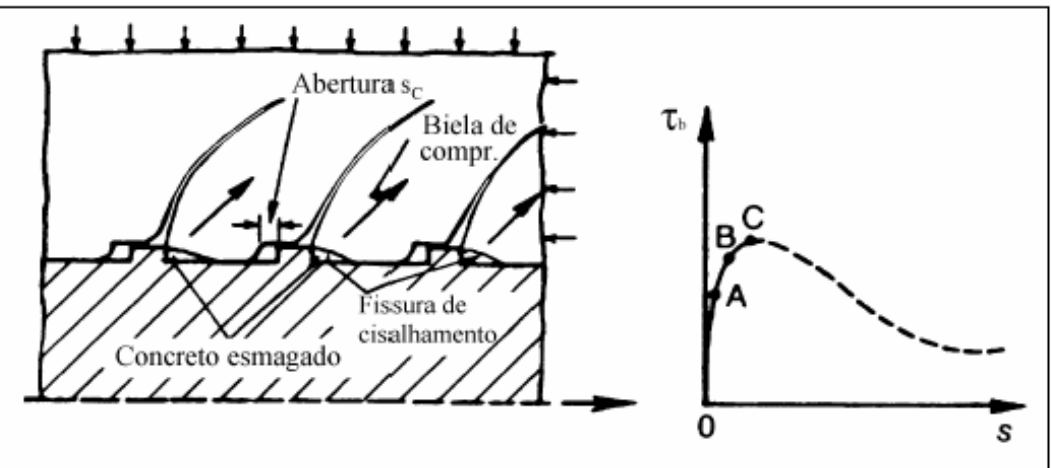

Figura 2.15 - Descolamento do concreto entre as nervuras(Soroushian e Choi, 1989)

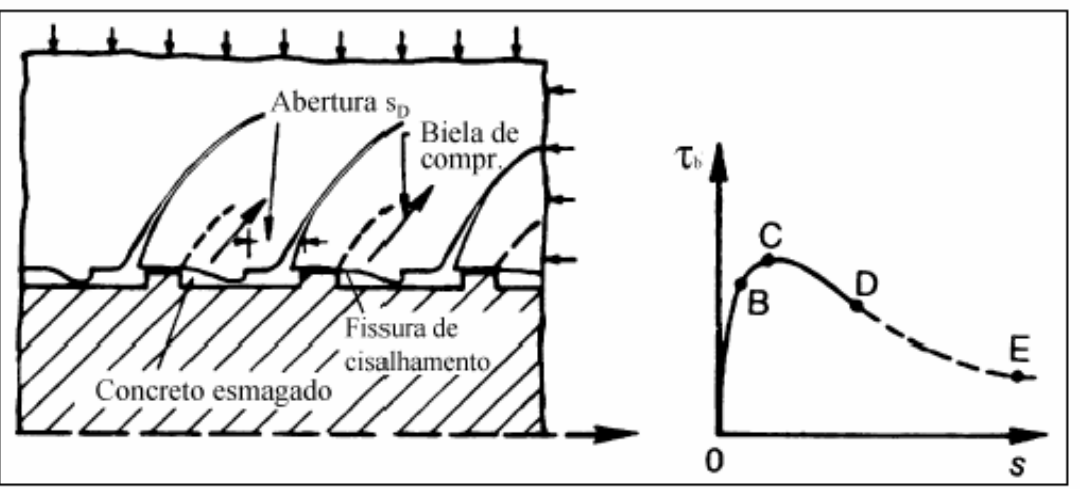

Figura 2.16 - Esmagamento e fissura de cisalhamento entre as nervuras (Soroushian e Choi, 1989)

Em outro estudo de Soroushian e Choi (1991) testes de arrancamento foram desenvolvidos em barras nervuradas com apenas uma parte do seu comprimento em contato com o concreto confinado (Figura 2.17). Os modelos representam a região confinada de uma ligação viga-pilar. O aço confinado (barras verticais e transversais) dos modelos representa o pilar armado. Apenas um pequeno comprimento $(5 \Phi)$ da barra nervurada foi aderida ao concreto, sendo pequeno o suficiente de modo a produzir aproximadamente tensão de aderência e distribuição de deformação uniformes ao longo do comprimento, mas grande o suficiente para reduzir a dispersão do resultado do ensaio, o 
que é usualmente observado com comprimento de aderência muito pequeno. Foi feito isso, pois, normalmente em condições de ancoragem com barra reta, os comprimentos de ancoragem relativos conduzem a uma tensão de aderência e uma distribuição de deformação não-uniforme ao longo do comprimento de ancoragem.

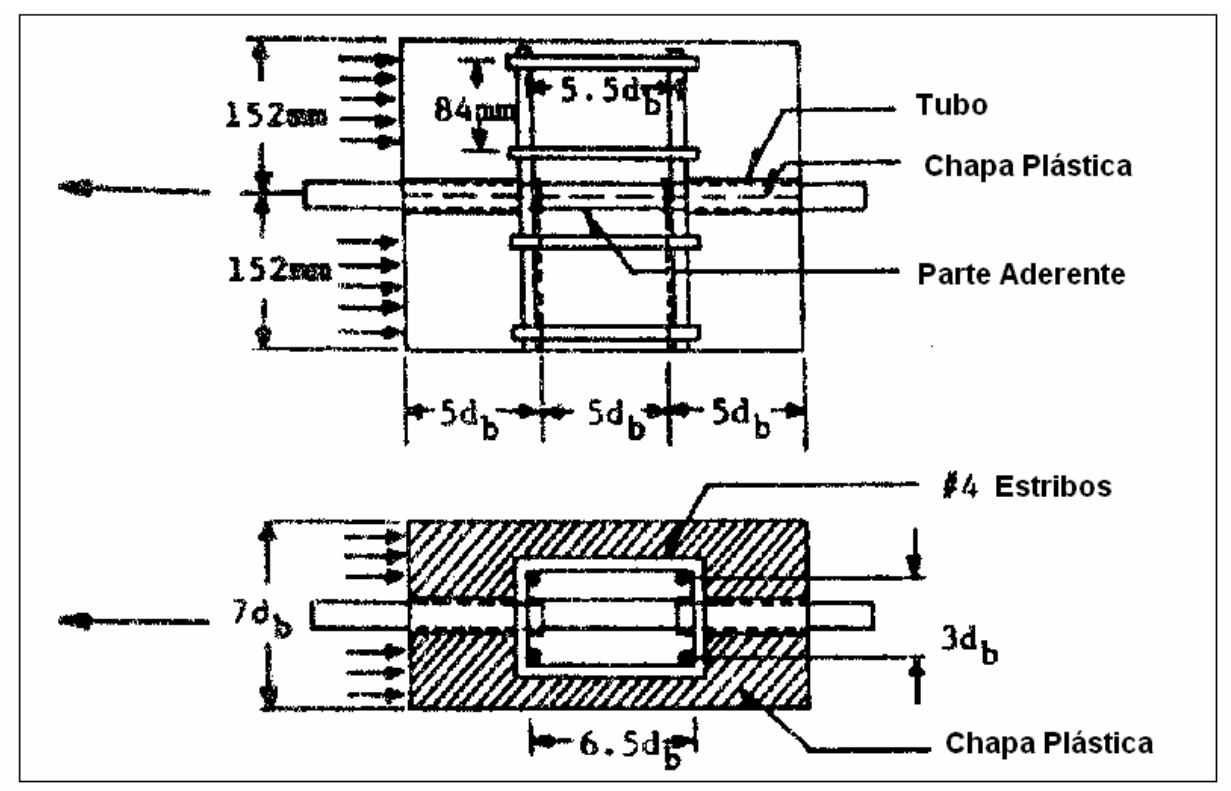

Figura 2.17 - Modelo de ensaio (Soroushian e Choi, 1991)

Os efeitos do diâmetro da barra sobre a relação tensão-deformação para aderência localizada são mostrados na Figura 2.18, que apresenta a média de dois resultados para cada diâmetro ensaiado. Observa-se que a tensão de aderência última aumenta com a diminuição do diâmetro da barra. Para as maiores deformações na região pós-pico, entretanto, a influência do diâmetro da barra tende a ser menos significante. A rigidez tangente da aderência localizada na região pré-pico (especialmente próximo às tensões de pico) tende a ser maior para barras com diâmetros menores.

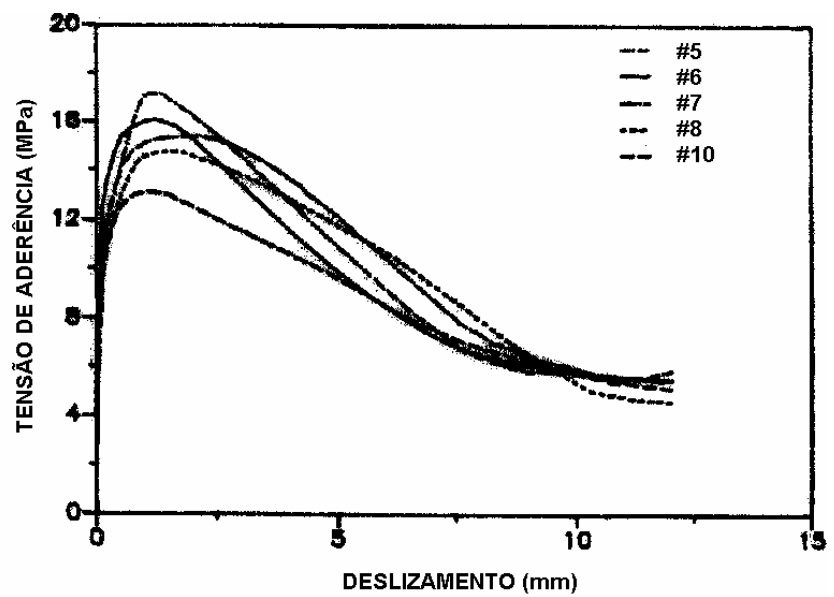

Figura 2.18 - Relações tensão de aderência-deslizamento para barras de diferentes diâmetros (Soroushian e Choi, 1991) 
A forma analítica geral capaz de reproduzir os resultados experimentais é a mostrada na Figura 2.19. A curva consiste de um segmento ascendente curvo-linear, um segmento de reta paralelo ao eixo dos deslizamentos definindo a tensão máxima, um ramo descendente linear e outro trecho reto final na aderência de atrito. Dois valores particulares de tensão ( $\tau_{1}$ correspondente ao pico e $\tau_{3}$ correspondente à aderência de atrito) e três valores particulares de deslizamento $\left(S_{1}, S_{2}\right.$ e $S_{3}$, correspondentes aos pontos iniciais do segmento reto do pico, do ramo descendente, e da reta final, respectivamente) podem ser derivados empiricamente por modelos propostos analiticamente.

Utilizando a forma analítica geral com uma resistência à compressão constante de 30 $\mathrm{MPa}$, os valores particulares de deformação, $S_{1}, S_{2}$ e $S_{3}$, bem como a tensão de atrito $\tau_{3}$, são independentes do diâmetro da barra. A tensão de ruptura $\tau_{1}$, diferente dos demais valores particulares, é dependente do diâmetro da barra. A resistência de ruptura e o diâmetro da barra apresentam uma relação linear (baseada numa regressão linear).

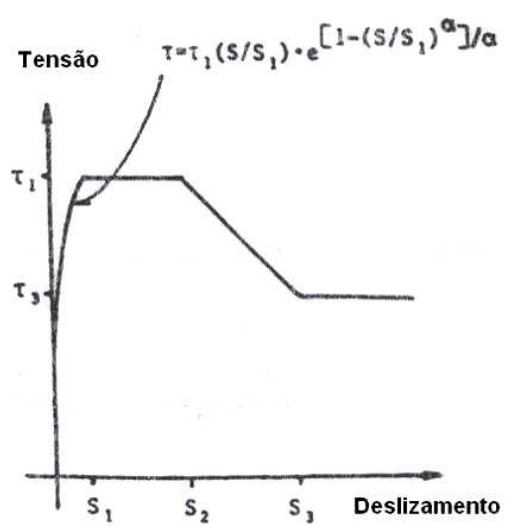

Figura 2.19 - Forma geral da relação tensão-deslizamento da aderência (Eligehausen et al.,1983)

Com esse estudo pôde-se concluir que: a) a resistência de aderência diminui com o aumento do diâmetro da barra e a queda na resistência é linear ao diâmetro da barra;. b) há um ligeiro aumento da rigidez tangente no pré-pico (especialmente próximo à resistência de pico) com a diminuição do diâmetro da barra; c) a resistência pós-pico, especialmente para as maiores deformações, não é fortemente influenciada pelo diâmetro da barra ancorada; d) os valores particulares de deformação (por exemplo, aqueles correspondentes à resistência de pico) não são influenciados consistentemente pelo diâmetro da barra.

\subsubsection{Ancoragem}

A soma das tensões de tração transversais à barra produz a força de tração transversal no concreto, também denominada tensão de fendilhamento. 
Com cobrimento de concreto pequeno em relação ao diâmetro da barra ou o espaçamento pequeno entre as barras, ocorre o risco de aparecerem grandes fissuras longitudinais, ou de fendilhamento (Figura 2.20), ou mesmo de se romper o cobrimento de concreto por causa das tensões de fendilhamento na zona de ancoragem. Tendo em vista a pequena resistência à tração do concreto, principalmente na direção vertical (direção da concretagem), é preciso ter cuidado com essas tensões de fendilhamento em qualquer local da ancoragem e, também, em outros locais onde as barras estejam sujeitas a elevadas tensões de aderência, especialmente naqueles pontos onde o concreto for solicitado à tração, transversalmente à barra, em virtude de outras causas. Quando uma compressão transversal favorável não atuar na zona de ancoragem, é necessário utilizar uma armadura transversal externa, ao longo do comprimento necessário à ancoragem (comprimento de ancoragem), capaz de absorver as tensões de fendilhamento.

As zonas favoráveis de ancoragem são aquelas em que existe uma compressão transversal à barra, em pelo menos uma direção, nessas zonas, os comprimentos de ancoragem podem ser reduzidos.

A ancoragem por aderência significa que as bielas de compressão se apóiam nas nervuras da barra e provocam tração na direção transversal à barra.

Cuidados com relação à ancoragem devem ser tomados, principalmente em relação à força cortante atuante e proximidades com outras armaduras.
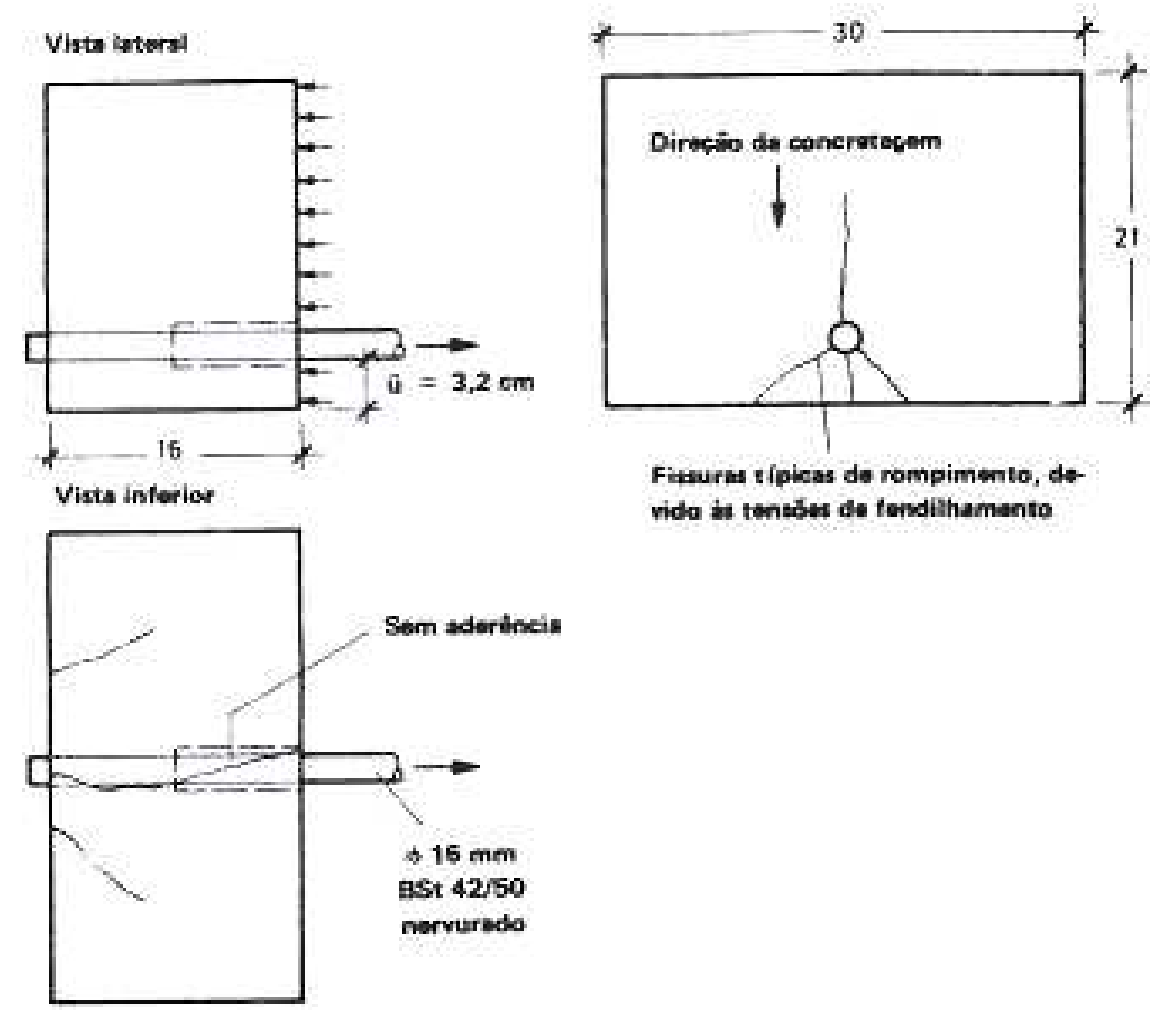

Figura 2.20 - Fissuras devido ao fendilhamento (Leonhardt, 1978) 


\subsubsection{Confinamento}

O confinamento é utilizado em elementos estruturais visando melhorar no elemento estrutural a ductilidade e a resistência com relação às ações estáticas, sísmicas ou cíclicas. É importante em elementos estruturais submetidos a ações de grande intensidade, onde essa ação inicia um processo de fissuração provocado por deformações transversais normais à ação. Essas deformações transversais são impedidas, o elemento estrutural aumenta sua capacidade resistente e ganha ductilidade.

O confinamento em tubo de aço, em virtude de sua elevada rigidez transversal, apresenta-se como um confinamento ativo, pois elevadas pressões laterais são atingidas, retardando a formação das primeiras micro-fissuras. Além disso, melhora a ductilidade do concreto, por causa do acréscimo de pressão lateral após o escoamento do aço em função de seu encruamento.

Soroushian et al. (1991) realizaram um estudo experimental analisando os efeitos do confinamento e a resistência à compressão do concreto sobre a aderência de barras nervuradas em ligações, considerando a relação tensão de aderência-deslizamento. Fissuras de fendilhamento são contidas pelas armaduras que atravessam estas fissuras. Com relação à resistência à compressão do concreto, a aderência de ruptura aumenta proporcionalmente com a sua raiz quadrada, já o efeito do confinamento teve insignificante efeito sobre o comportamento da aderência.

Eligehausen et al. (1983) apud Soroushian et al. (1991) obtiveram resultados indicando que um concreto de maior resistência à compressão tende a ter maior rigidez na aderência, na resistência e na resistência pós-pico (Figura 2.21).

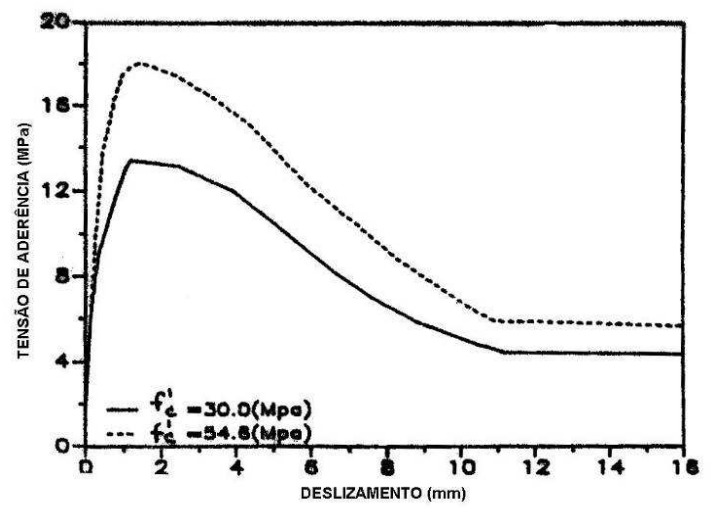

Figura 2.21 - Comportamento da aderência conforme a resistência à compressão do concreto((Eligehausen et al. ,1983, apud Soroushian et al. ,1991) 
Eles desenvolveram um modelo empírico para prever a relação tensão-deslizamento da aderência em concretos confinados com diferentes resistências à compressão. Os valores para o modelo empírico estão na Tabela 2.1 e uma exemplificação é mostrada na Figura 2.22. onde foi utilizada a forma analítica geral capaz de reproduzir os resultados experimentais e foi mostrada na Figura 2.19.

Tabela 2.1 - Valores empíricos e expressões para os valores de tensão e deslizamento da aderência (Eligehausen et al.,1983)

\begin{tabular}{cccccc}
\hline Parâmetro & $\tau_{1}, \mathbf{M P a}$ & $\tau_{3}, \mathbf{M P a}$ & $\boldsymbol{S}_{1}, \mathbf{m m}$ & $\boldsymbol{S}_{2}, \mathbf{m m}$ & $\boldsymbol{S}_{3}, \mathbf{m m}$ \\
\hline Valor & $\left(20-\mathrm{d}_{\mathrm{b}} / 4\right) \sqrt{f_{c}^{\prime} / 30}$ & 5.0 & 1.0 & 3.0 & 10.5 \\
\hline
\end{tabular}

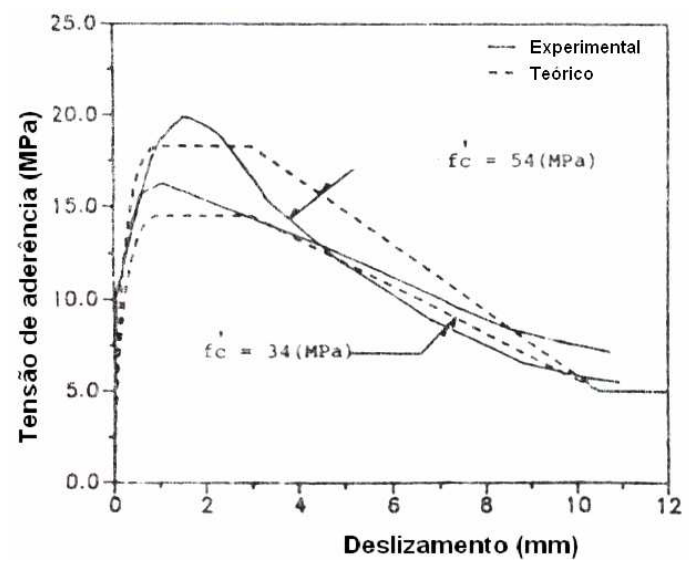

Figura 2.22 - Comparação da relação tensão-deslizamento analítica e experimental (diâmetro da barra $=25 \mathrm{~mm})$ (Eligehausen et al., 1983)

Em pesquisa apresentada por Einea et al. (1995) foi analisado o efeito do confinamento do concreto, que permite o aumento da força efetiva da ligação entre barras de aço e graute confinado numa emenda de tubo de aço.

O objetivo era comparar vários tipos de emendas para obter uma ótima, com um projeto prático, levando em consideração também o custo e a facilidade de construção.

Para tanto, alguns parâmetros foram variados como a intensidade de confinamento, comprimentos de ancoragem ou transpasse, resistência à compressão do graute, espessura do cobrimento, diâmetro do tubo, diâmetro das barras e resistências do aço. A Figura 2.23 mostra o modelo de ensaio que obteve o melhor desempenho e a Tabela 2.2 destaca suas propriedades e resultados dos ensaios.

Com exceção do modelo 5 , todos os modelos romperam por falta de aderência entre a barra e o graute, e, além disto, a maioria rompeu com uma tensão axial maior que a tensão de escoamento da barra. Como o alto confinamento evitou o fendilhamento do 
graute, os modelos resistiram à força de tração até o cisalhamento do graute com a deformação da barra. No modelo 5 , tipo 3 , a resistência à ruptura da barra foi alcançada antes da falha na aderência.

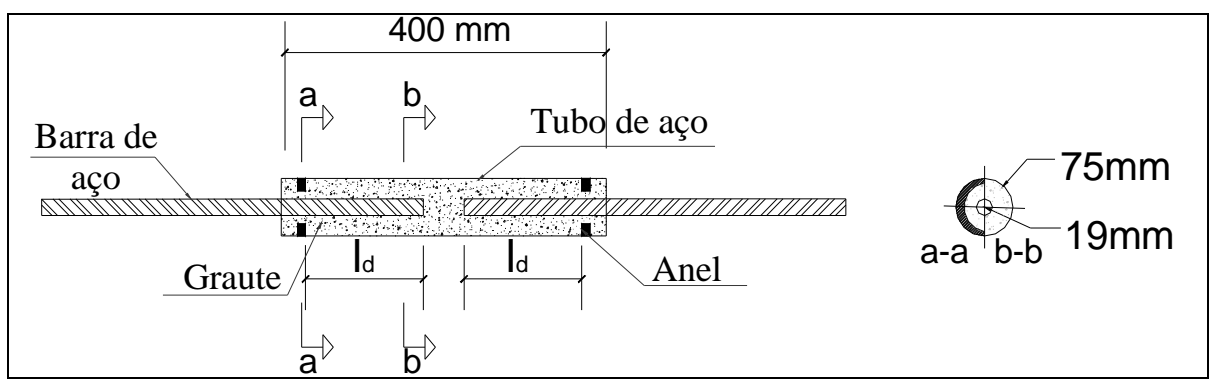

Figura 2.23 - Modelo de ensaio (adaptado de Einea et al., 1995)

Tabela 2.2 - Resumo dos resultados dos ensaios ( Einea et al.,1995)

\begin{tabular}{|c|c|c|c|c|c|c|}
\hline $\begin{array}{c}\text { Tipo } \\
\text { Do } \\
\text { Modelo }\end{array}$ & $\begin{array}{c}\text { Número } \\
\text { Do } \\
\text { modelo }\end{array}$ & $\begin{array}{c}I_{d} \\
(m m)\end{array}$ & \begin{tabular}{|c|} 
Força axial \\
na ruptura \\
$(\mathrm{kN})$
\end{tabular} & $\begin{array}{c}\text { Tensão axial } \\
\text { na ruptura } \\
\text { (MPa) }\end{array}$ & $\begin{array}{c}\text { Tensão média } \\
\text { de aderência } \\
(\mathrm{MPa})\end{array}$ & $\begin{array}{c}\text { Resist.compressão } \\
\text { do graute } \\
\text { (MPa) }\end{array}$ \\
\hline & 1 & 177,7 & 156,6 & 551,2 & 14,7 & \\
\hline Tipo 3 & 2 & 152,4 & 113,4 & 399,6 & 12,4 & 44,8 \\
\hline Tubo com & 3 & 127,0 & 105,4 & 371,4 & 13,9 & \\
\hline Anel & 4 & 177,7 & 200,6 & 706,2 & 18,8 & \\
\hline \multirow[t]{2}{*}{ de aço } & 5 & 152,4 & 198,8 & 700,0 & 21,8 & 68,9 \\
\hline & 6 & 127,0 & 146,8 & 516,8 & 19,3 & \\
\hline
\end{tabular}

A capacidade resistente dos modelos 4,5 e 6 foi pelo menos $125 \%$ da resistência de escoamento especificada do aço.

As variáveis físicas que podem afetar na resistência da ligação de barras confinadas em tubo de aço incluem a resistência de escoamento da barra de aço, a resistência do graute e as propriedades do tubo. As variáveis geométricas são o diâmetro e geometria da barra, além do seu comprimento de embutimento dentro do graute confinado, diâmetro interno do tubo, espessura da parede do tubo e geometria das extremidades livres do tubo.

A resistência à tração dos modelos ensaiados aumenta em função do comprimento de ancoragem ou de transpasse e da resistência à compressão do graute para todos os modelos. Embora a ruína da ligação ocorra na superfície externa às deformações das barras, a resistência de ruptura média da ligação, U, é calculada conforme Equação 2.1 a seguir:

$$
U=\frac{F}{\pi \times \phi \times l_{d}}
$$


Sendo:

$F=$ força de ruptura;

$\phi=$ diâmetro nominal da armadura principal;

$l_{d}=$ Comprimento de ancoragem ou de transpasse.

Os resultados deste programa experimental proporcionaram dados válidos sobre o efeito da resistência à compressão do graute e a intensidade de confinamento na resistência da ligação em tubos de aço. Constatou-se que uma simples emenda com tubo de aço preenchido com graute pode desenvolver uma resistência mínima de $125 \%$ da resistência ao escoamento de uma única barra.

Além disso, pode-se alcançar alta resistência de aderência com o confinamento do graute obtendo assim comprimento de ancoragem ou de transpasse das barras bem pequeno. Outro fator que aumenta a resistência da emenda é a solda de anéis de aço nas extremidades dentro do tubo, cuja pequena redução na abertura final é suficiente para mobilizar a ação de confinamento do graute.

Einea et al. (1999), em outro estudo, apresentaram pesquisa sobre comportamento de emendas sob tração confinadas por armaduras em espiral no concreto. Primeiramente foram feitos ensaios para se obter o melhor detalhamento da emenda com relação à capacidade e à simplicidade de fabricação. A partir dela foram analisados os parâmetros de resistência do concreto, diâmetro da barra, número de espirais e comprimento de ancoragem. Foi constatado que esse confinamento pode resultar em significante redução no comprimento de ancoragem necessário. O comprimento de ancoragem por confinamento com barras em espiral aumenta linearmente com o diâmetro e a resistência de escoamento das barras nervuradas que estão sendo emendadas, e inversamente com a raiz quadrada da resistência à compressão do concreto, bem como com a diferença entre o diâmetro do espiral e da barra. Já a excentricidade do espiral relativa à armadura principal não teve aparente efeito sobre o desempenho da emenda.

Moosavi et al. (2003) realizaram ensaios para quantificar o efeito da pressão de confinamento na capacidade de aderência em modelos sob tensão radial constante. Os resultados mostraram uma relação não-linear entre o aumento da capacidade de aderência e a pressão de confinamento. Com o aumento da pressão de confinamento foram conseguidas maiores capacidades de aderência e menores dilatações. Além disso, grautes de pequena qualidade geraram menores deformações bem como menor capacidade de aderência, enfatizando a importância do controle de qualidade no grauteamento. 


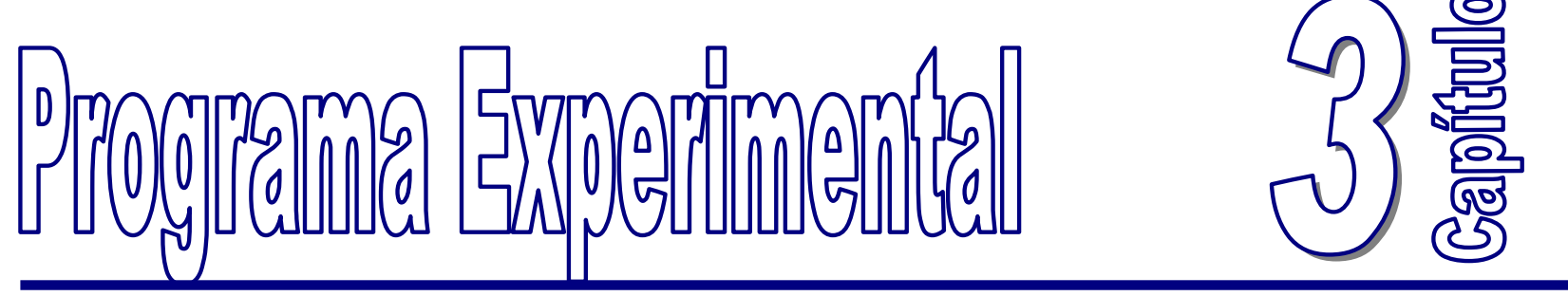

\subsection{Considerações Iniciais}

O objeto de estudo desta pesquisa é uma emenda de barras, com a finalidade de transmissão de forças em elementos pré-moldados. Ela é constituída por um tubo de aço preenchido por graute e com duas barras de aço alinhadas, sendo uma em cada extremidade, representando duas emendas (Figura 3.1).

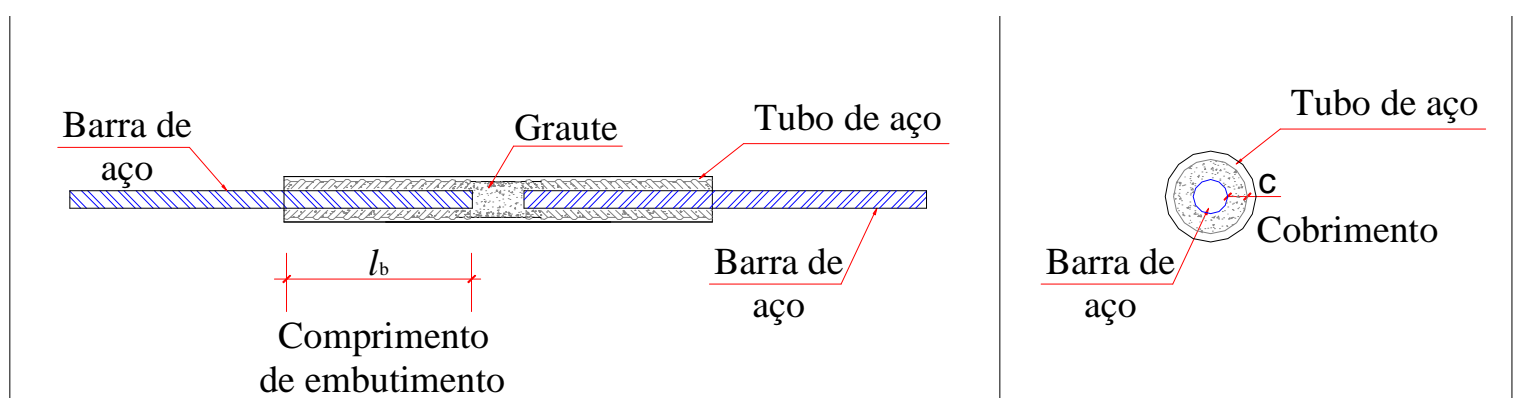

Figura 3.1 - Emenda de barras

A partir da pesquisa bibliográfica definiram-se as principais variáveis que influenciam no comportamento da emenda. Após a identificação desses parâmetros, alguns foram escolhidos com o objetivo de analisar suas influências, por meio dos ensaios. Os parâmetros escolhidos foram: a) diâmetro das barras $(\Phi=16 \mathrm{~mm}, \Phi=20 \mathrm{~mm}$ e $\Phi=25$ $\mathrm{mm}$ ); b) cobrimento (c = 9,5 mm e c = $11 \mathrm{~mm}$ ); c) tipo de ação (monotônica e cíclica); d) comprimento de ancoragem ( $\varsigma_{b}=100 \mathrm{~mm}, \varsigma_{b}=200 \mathrm{~mm}$ e $\varsigma_{b}=300 \mathrm{~mm}$ ); e) posição da barra (centralizada ou excêntrica,na qual a barra será encostada na parede do tubo); f) conformação superficial interna do tubo (liso ou corrugado).

Depois, foi necessário o planejamento do esquema de ensaio, ou seja, dos dispositivos e de seus posicionamentos juntamente com a emenda e o atuador servo- 
hidráulico para montagem do ensaio.

Foram definidos os materiais empregados na emenda: graute, tubo de aço e barra de aço, conforme a disponibilidade comercial e limites de dimensões.

As emendas tiveram sua geometria definida a partir da resistência dos materiais e de um modelo simplificado da transmissão dos esforços pelas bielas de compressão, sendo o cobrimento mínimo de 5 mm, devido à tolerância conforme NBR 9062/1985 item 5.2.2.3.

Foi feita uma emenda para cada diâmetro com a barra encostada na parede do tubo (excêntrica), simulando falhas de execução às quais as peças estariam submetidas, representando a situação mais desfavorável, já que não se garante uma boa aderência entre a barra e o tubo, e uma conseqüente deficiência na transmissão das forças.

O programa experimental foi dividido nas seguintes etapas: a) definição do graute utilizado; b) caracterização dos materiais; c) ensaio da Série Piloto; d) ensaio da Série Definitiva.

\subsection{Definição do graute utilizado}

O graute (Figura 3.2) é um material fluido e auto-adensável no estado recémmisturado, formulado para preencher cavidades e subsequentemente tornar-se aderente, resistente e sem retração no seu estado endurecido.

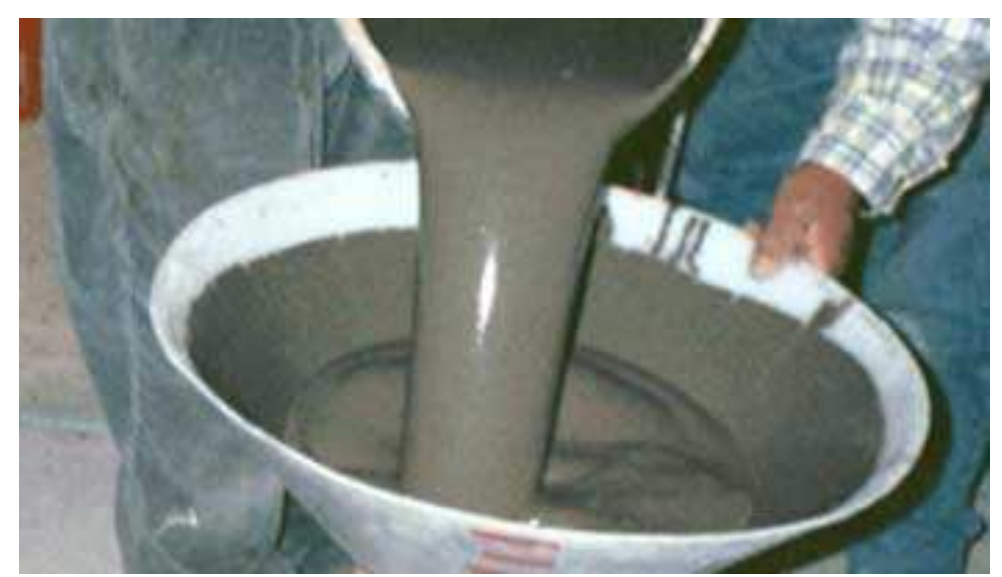

Figura 3.2 - Graute

Graute nada mais é do que um concreto, pois é formado pelos mesmos materiais (água, cimento, agregados e aditivos), que possui algumas particularidades, como a dimensão característica máxima dos agregados e presença de aditivos que permitam as 
mais diversas propriedades como: trabalhabilidade, consistência adequada, retração controlada, capacidade de retenção de água, resistência à compressão e aderência.

Entre as diversas utilizações do graute estão a fixação de equipamentos, obras de reparo, reforço estrutural, recuperação estrutural, incremento da capacidade resistente da parede na alvenaria estrutural, preencher pequenos espaços vazios, grauteamento em elementos estruturais de concreto pré-moldado de concreto armado ou protendido, ancoragens, concretar locais de difícil acesso ou seções densamente armadas.

As propriedades esperadas do graute para esta pesquisa são: alta resistência à compressão inicial e final, grande fluidez, compacidade, alta resistência de aderência com aço e pequena retração. Com isso, pesquisou-se no mercado o que havia disponível e foram feitos, simplesmente, ensaios de resistência à compressão e de módulo de elasticidade para definir o melhor material a ser empregado. Foram escolhidos, conforme propriedades dispostas pelos fabricantes, os seguintes grautes comerciais:

- $\quad V$-1 Grauth - argamassa de altas resistências iniciais e finais para grauteamentos $(\mathrm{V} 1)$;

- $\quad$-2 Grauth - argamassa expansiva de alta resistência para grauteamentos (V2);

- Masterflow ${ }^{\circledR} 885$ Grout - argamassa fluida de altíssima resistência com retração compensada e agregados metálicos (M1);

- Masterflow ${ }^{\circledast} 211$ - graute epóxi, fluido, para ancoragens e reparações (M2).

A resistência à compressão $\left(f_{c}\right)$ foi calculada a partir do ensaio de três corpos-deprova cilíndricos de medidas $5 \mathrm{~cm} \times 10 \mathrm{~cm}$ para cada data de ensaio: $24 \mathrm{~h}$, 3 dias e 28 dias após a moldagem, ensaiadas na máquina hidráulica automática (ELE) à velocidade de 0,5 $\mathrm{kN} / \mathrm{s}$. O módulo de elasticidade longitudinal tangente $\left(E_{c}\right)$ foi obtido a partir do ensaio de três corpos-de-prova cilíndricos de medidas $5 \mathrm{~cm} \times 10 \mathrm{~cm}$, aos quatro dias após a moldagem, ensaiados na máquina de ensaios universal (INSTRON, modelo 8506).

Dentre os produtos analisados utilizou-se o Masterflow ${ }^{\circledR} 885$ Grout, com relação água/aglomerante $=0,12$ conforme resultados mostrados no capítulo seguinte. 


\subsection{Caracterização dos materiais}

\subsubsection{Graute}

O graute utilizado em todas as emendas foi o Masterflow ${ }^{\circledR} 885$ Grout (argamassa fluida de altíssima resistência com retração compensada e agregados metálicos), marca BASF, cujas propriedades fornecidas pelo fabricante estão indicadas na Tabela 3.1.

Tabela 3.1 - Dados técnicos do Masterflow ${ }^{\circledast} 885$ Grout (http://www.degussa-cc.com.br, 2005)

\begin{tabular}{cc}
\hline Principal função & $\begin{array}{c}\text { Graute estrutural } \\
\text { Base química }\end{array}$ \\
Aspecto & $\begin{array}{c}\text { Cimento Portland, aditivos especiais, } \\
\text { agregados minerais e metálicos }\end{array}$ \\
Densidade & Pó \\
Cor & Cinza \\
Fluidez ASTM C939 & Passa em mais de 30s \\
Fim de Pega & Maior que 8 horas \\
Resistência a Compressão & 24 horas $>28,0 \mathrm{MPa}$ \\
& 3 dias $>34,0 \mathrm{MPa}$ \\
I- ASTM C492 & 7 dias $>48,0 \mathrm{MPa}$ \\
Resistência à Tração & 28 dias $>62,0 \mathrm{MPa}$ \\
na Flexão - ASTM C78 & 3 dias $>6,0 \mathrm{MPa}$ \\
& 7 dias $>7,2 \mathrm{MPa}$ \\
\hline
\end{tabular}

\subsubsection{Execução da Mistura}

De acordo com as recomendações do fabricante o traço pode variar com o fator água/aglomerante de 0,17 a 0,2, conforme a fluidez desejada. Neste caso foi utilizado o traço com fator água/aglomerante de 0,2, pois era necessário um graute bem fluido em virtude das pequenas dimensões para o grauteamento.

A mistura foi feita em uma batedeira planetária BP 20C, da marca G. PANIZ, potência de $1 \mathrm{CV}$, com cuba em aço inoxidável (capacidade de 20 litros) e eixo vertical (Figura 3.3). O batedor utilizado foi tipo espiral e os materiais colocados na seguinte ordem:

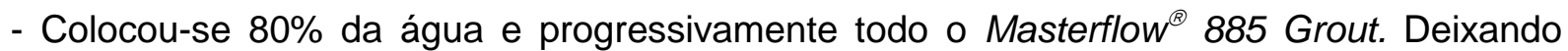
bater à velocidade de 85 RPM por 3 minutos; 
- Acrescentou-se o restante da água e bateu-se por mais 5 minutos à mesma velocidade de 85 RPM.
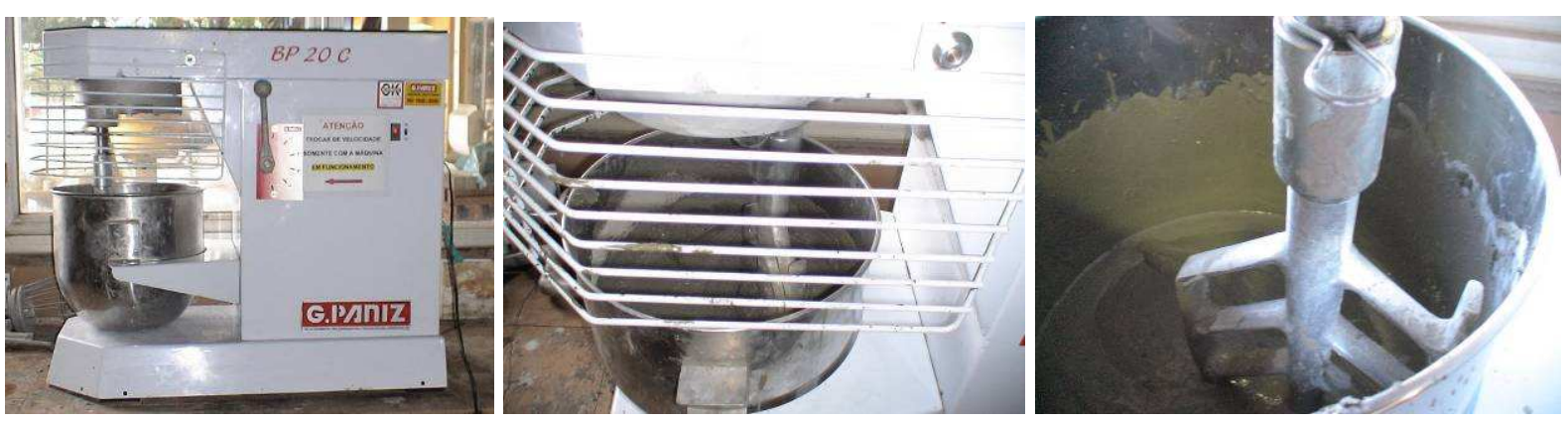

Figura 3.3 - Mistura do graute

\subsubsection{Resistência à compressão}

As resistências à compressão $\left(f_{c}\right)$ foram obtidas com ensaios de três corpos-de-prova cilíndricos $5 \mathrm{~cm} \times 10 \mathrm{~cm}$ para cada uma das quatro misturas de graute utilizadas, uma para a série piloto e as outras três para a série definitiva, sendo a primeira para a série 1 , a segunda para a série 2 e a última para a série 3 (Figura 3.4).

Os corpos-de-prova foram desformados um dia após a moldagem e mantidos na câmara úmida até a data do ensaio das emendas. Foram ensaiados na máquina hidráulica automática (ELE) à velocidade de $0,5 \mathrm{kN} / \mathrm{s}$.

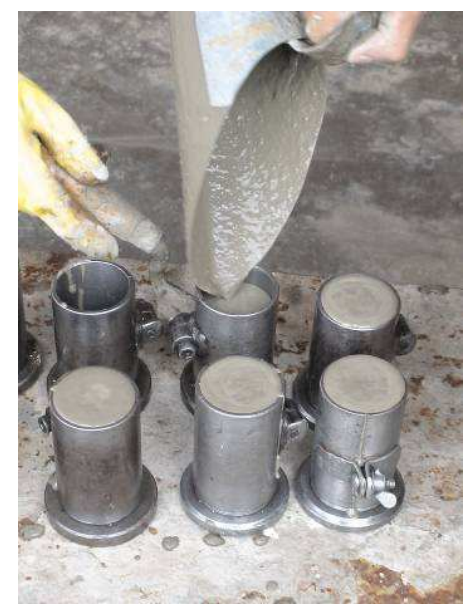

Figura 3.4- Moldagem dos corpos-de-prova 


\subsubsection{Resistência à tração}

As resistências à tração indireta do concreto $\left(f_{c t, s p}\right)$ foram calculadas conforme a Equação 3.1 a partir dos resultados obtidos pelo ensaio de compressão diametral, conforme NBR 7222/1994. Como o plano de fratura imposto pelo arranjo do ensaio de compressão diametral não se constitui obrigatoriamente no plano de menor resistência, os resultados deste ensaio, são sistematicamente maiores que os do ensaio de tração pura. Portanto, a resistência à tração do ensaio de compressão diametral é multiplicada por 0,85.

$$
f_{c t, s p}=\frac{2 F_{j}}{\pi \cdot d_{j} \cdot h}
$$

$f_{t} \quad=$ Resistência à tração do concreto ;

$F_{j} \quad=$ Força aplicada no corpo-de-prova $(\mathrm{kN})$;

$d_{j} \quad=$ Diâmetro do corpo-de-prova $(\mathrm{mm})$;

$h \quad=$ Comprimento do corpo-de-prova $(\mathrm{mm})$;

$$
f_{t}=0.85 \cdot f_{c t, s p}
$$

Foram utilizados três corpos-de-prova cilíndricos de medidas $5 \mathrm{~cm} \times 10 \mathrm{~cm}$ para cada série, que foram desformados um dia após a moldagem e mantidos na câmara úmida até a data do ensaio. Foi utilizada a máquina hidráulica manual ELE com controle manual da velocidade.

\subsubsection{Módulo de elasticidade}

Os módulos de elasticidade longitudinal tangente $\left(E_{c}\right)$ foram obtidos com ensaios de corpos-de-prova cilíndricos de medidas $5 \mathrm{~cm} \times 10 \mathrm{~cm}$, ensaiados na máquina de ensaios universal (INSTRON). Para o cálculo do módulo optou-se por ensaiar apenas três corposde-prova na data do ensaio.

\subsubsection{Barras de aço}

Foram empregadas barras de aço da categoria CA-50 com superfície nervurada, produzidas conforme as especificações da norma NBR 7480/1996, com diâmetros nominais de $16 \mathrm{~mm}, 20 \mathrm{~mm}$ e $25 \mathrm{~mm}$.

O padrão de nervuras é caracterizado por nervuras transversais, inclinadas em relação ao eixo da barra, e por duas nervuras longitudinais diametralmente opostas, cujos eixos são paralelos ao eixo da barra. 
A determinação da resistência das barras de aço foi feita por meio do ensaio, conforme NBR 6152/1992, de três corpos-de-prova para cada diâmetro, sob tração até o escoamento, e a partir dos resultados foram calculadas a resistência média de escoamento ( $\left.f_{y m}\right)$ e a resistência média à tração $\left(f_{s t m}\right)$.

\subsubsection{Tubo de aço}

Foram empregados tubos mecânicos de aço carbono sem costura com alto teor de manganês com as propriedades mecânicas mostradas na tabela 3.2, conforme especificações fornecidas pelo fabricante, sendo para o ensaio piloto os de categoria DIN ST 52 com diâmetros externo de $60 \mathrm{~mm}$ e interno de $48 \mathrm{~mm}$, DIN ST 45 de diâmetros externo de $50 \mathrm{~mm}$ e interno de $44 \mathrm{~mm}$ e SAE 1020 de diâmetros externo de $44.5 \mathrm{~mm}$ e interno de $33 \mathrm{~mm}$ (Figura 3.5), e para o ensaio definitivo os de categoria DIN ST 52 com as propriedades geométricas conforme tabela 3.3 (Figura 3.6).

Tabela 3.2 - Propriedades mecânicas dos tubos empregados

\begin{tabular}{lcc}
\hline Tipo de aço Resistência de escoamento Resistência de ruptura \\
& (MPa) & (MPa) \\
\hline SAE 1020 & 207 & 380 \\
DIN ST 45 & 255 & $410-530$ \\
DIN ST 52 & 355 & $500-650$ \\
\hline
\end{tabular}

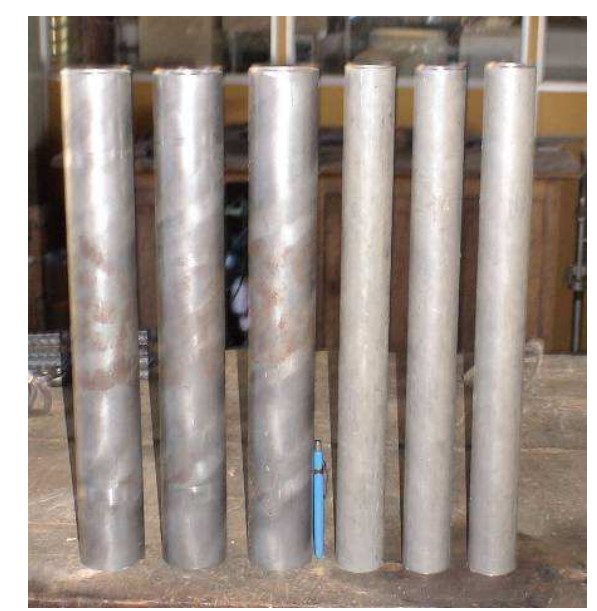

Figura 3.5 - Tubos com diâmetro externo de 60 e 44,5 mm para o ensaio piloto

Tabela 3.3 - Propriedades geométricas dos tubos empregados no ensaio definitivo

\begin{tabular}{ccc}
\hline $\boldsymbol{\emptyset}_{\text {int }}(\mathbf{m m})$ & $\boldsymbol{\sigma}_{\text {ext }}(\mathbf{m m})$ & Comprimento $(\mathbf{m m})$ \\
\hline 35 & 45 & 300 \\
35 & 45 & 500 \\
38 & 50 & 500 \\
47 & 57 & 700 \\
\hline
\end{tabular}



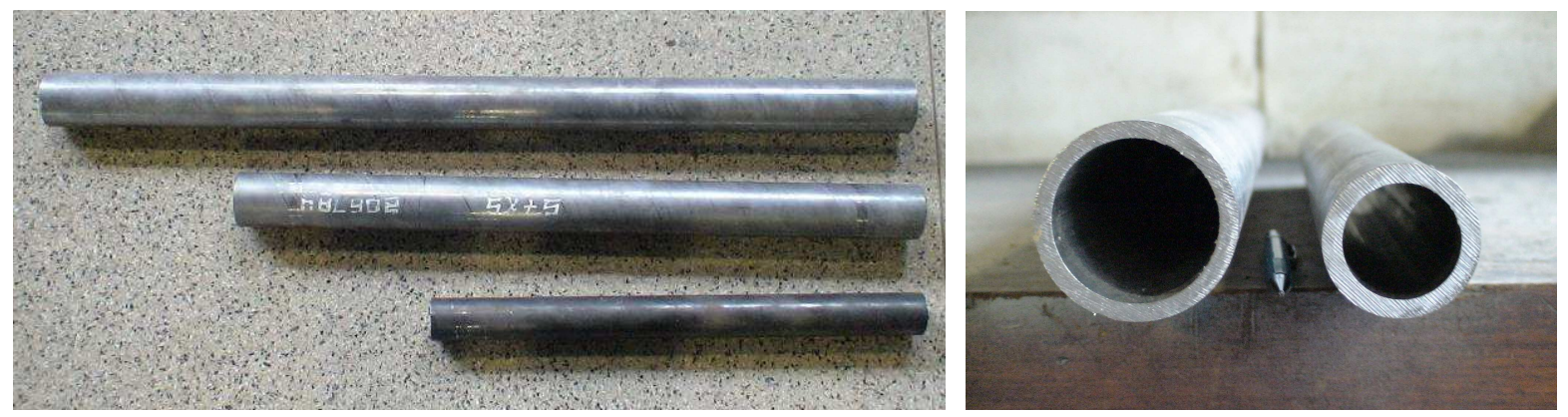

Figura 3.6 - Tubos para o ensaio definitivo com a) comprimento de $300 \mathrm{~mm}, 500 \mathrm{~mm}$ e $700 \mathrm{~mm}$ e b)diâmetro externo de $57 \mathrm{~mm}$ e $45 \mathrm{~mm}$

Os tubos fornecidos eram de conformação superficial interna lisa (Figura 3.7-a). Sendo alguns separados para serem corrugados pela empresa Proteu - Comércio e Fabricação de Equipamentos para Laboratórios, com nervuras com 2,5 mm de altura, $8 \mathrm{~mm}$ de largura e com espaçamento entre eixos de $16 \mathrm{~mm}$ e $15,5 \mathrm{~mm}$ para o ensaio piloto e definitivo respectivamente.

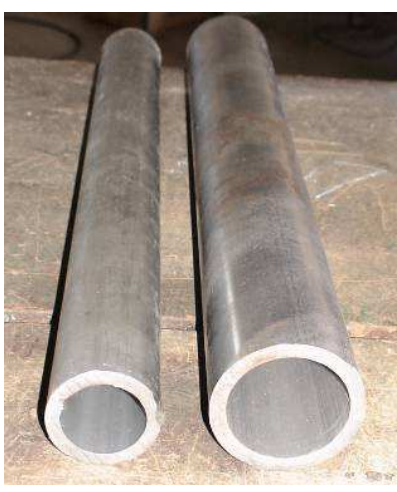

(a)

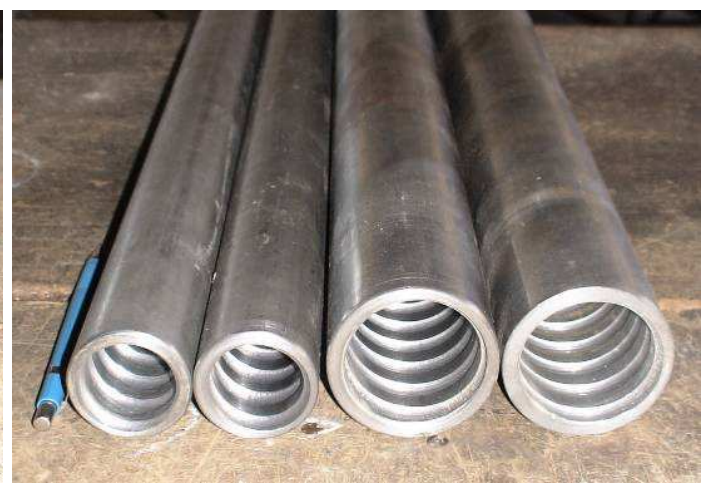

(b)

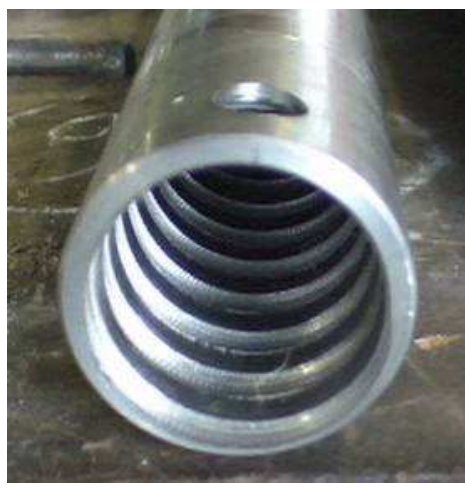

(c)

Figura 3.7 - Tubos a) lisos, b) corrugados para o ensaio piloto e c) corrugados para o ensaio definitivo

\subsection{Emenda}

A emenda é constituída por um tubo de aço preenchido com graute e duas barras de aço, uma em cada extremidade, com mesmo comprimento de ancoragem, sendo, assim, equivalente a duas emendas (Figura 3.8). Essas barras foram unidas por um tubo de PVC para garantir o mesmo posicionamento e evitar o aparecimento de flexão localizada. (Figura 3.9). 


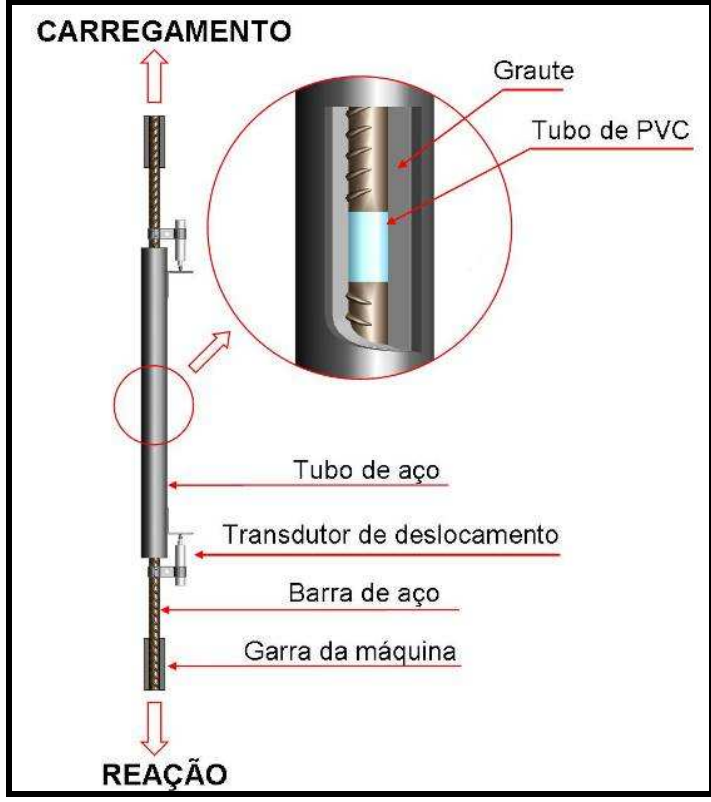

(a)

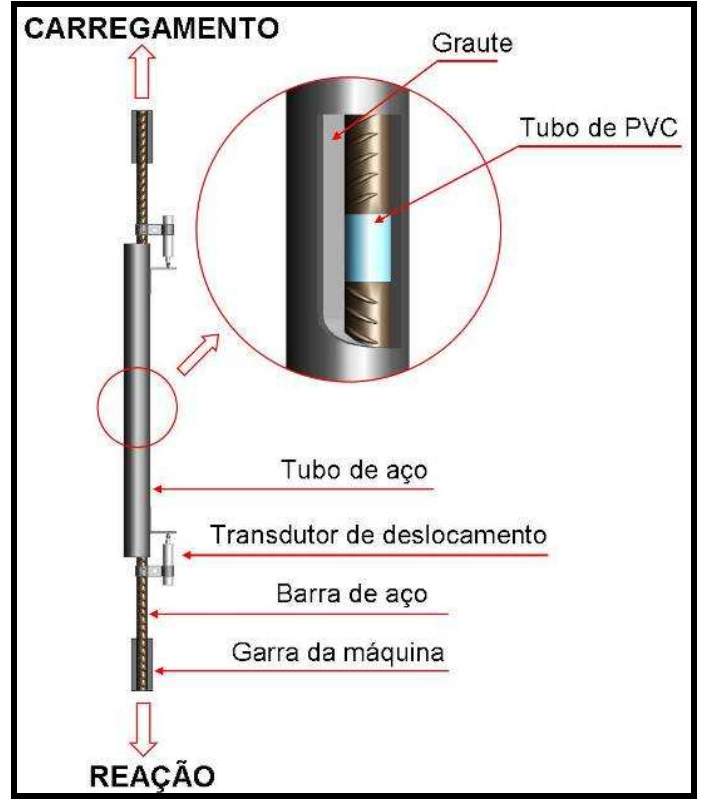

(b)

Figura 3.8 - Emenda ensaiada com a barra a) centralizada e b) excêntrica

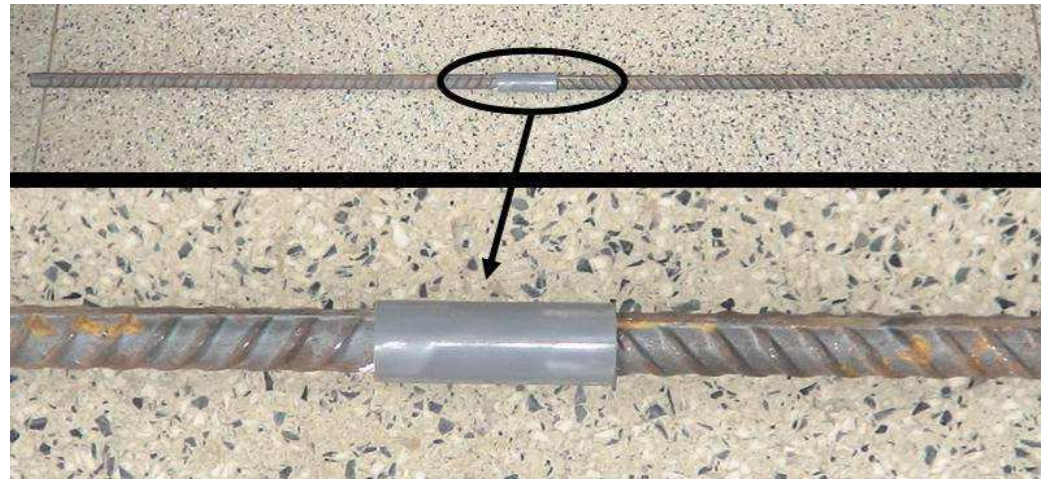

Figura 3.9 - Barras de aço unidas por tubo de PVC

A emenda foi submetida a ações monotônicas de tensão axial, com controle de deslocamento, até atingir a ruína, verificando a capacidade última da emenda e seus modos de ruína. A extremidade de uma barra foi presa à garra superior e tracionada, enquanto que a extremidade da outra barra era presa à garra inferior da máquina universal INSTRON, sofrendo a reação (Figura 3.8).

Existem duas formas de realização do ensaio de arrancamento sob ação cíclica: em uma, aplica-se a amplitude de força até a ruína da emenda; na outra, aplica-se um determinado número de ciclos e a partir daí, leva-se a emenda à ruína monotônica. Pretendia-se avaliar a redução da resistência da ligação por causa da ação cíclica, por isso optou-se pela segunda forma de ensaio. Algumas emendas foram submetidas a ações cíclicas prévias, onde foram carregadas até um valor médio ( $60 \%$ e $80 \%$ da força de ruína) e 
descarregadas a $10 \%$ da força de ruína, sendo submetidas a 30 ciclos de força. Após os ciclos, procedia-se ao ensaio monotônico, conduzindo à ruína da emenda.

Em cada extremidade foi colocado um transdutor de deslocamento para medir o deslizamento da barra em relação ao tubo (Figura 3.10).
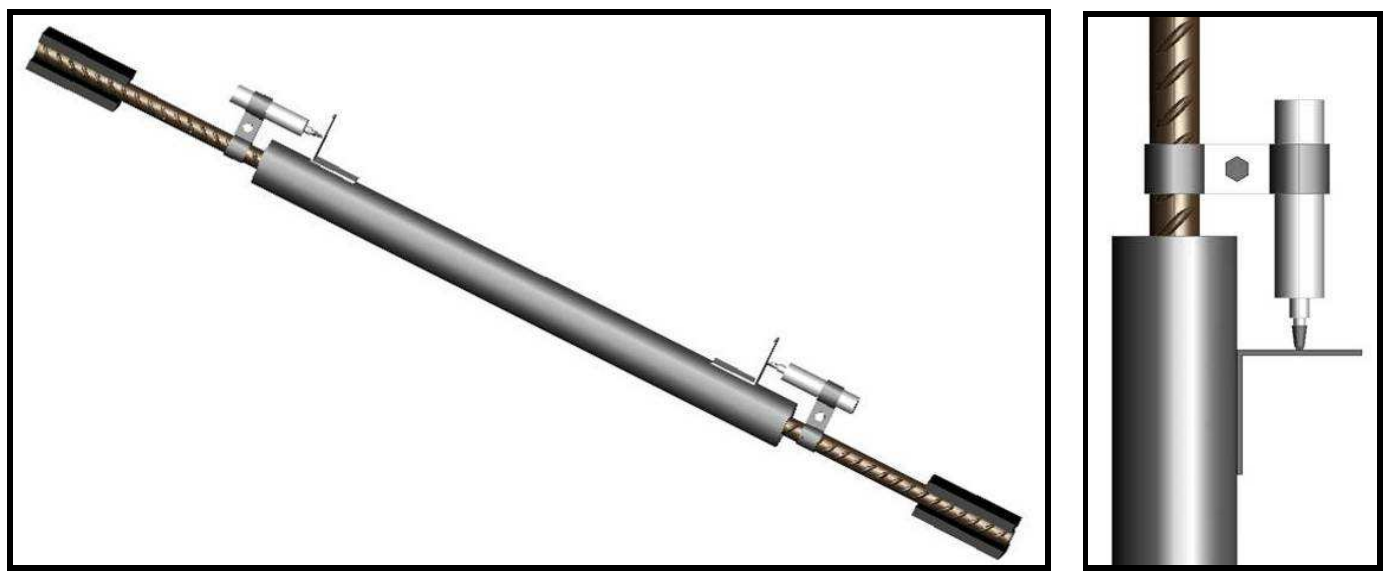

Figura 3.10- Transdutores de deslocamento na emenda estudada

A velocidade de aplicação da força foi calculada de acordo com o diâmetro da barra ensaiada. No caso das emendas com barras de $16 \mathrm{~mm}$, a velocidade adotada foi de 0,016 $\mathrm{mm} / \mathrm{s}$, nas emendas com barras de $20 \mathrm{~mm}$, a velocidade adotada foi de $0,02 \mathrm{~mm} / \mathrm{s}$, e nas emendas com barras de $25 \mathrm{~mm}$, a velocidade adotada foi de $0,025 \mathrm{~mm} / \mathrm{s}$, como foi adotada em FERNANDES (2000).

\subsection{Série Piloto}

Com a finalidade de verificar o desempenho da emenda, sua capacidade, seus dispositivos, avaliar as etapas de montagem e execução e detectar possíveis dificuldades, além de analisar o melhor posicionamento da instrumentação, foram executadas oito amostras preliminares, aqui denominados série-piloto, com o objetivo de orientar o campo da experimentação para o ensaio definitivo (Figura 3.11)

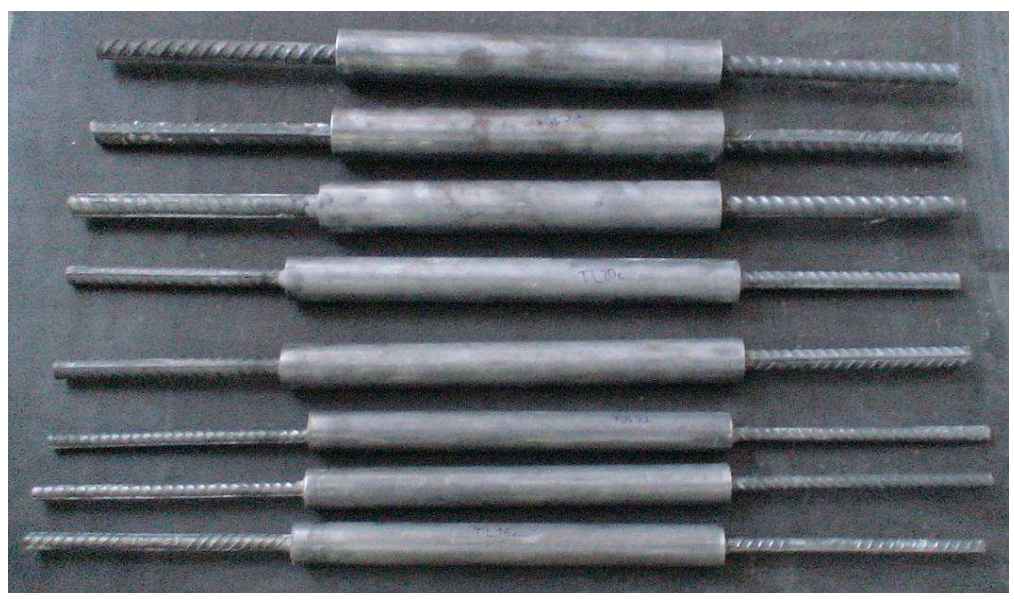

Figura 3.11- Emendas da série piloto 


\subsubsection{Moldagem das emendas}

Com o objetivo de se garantir o grauteamento do tubo de aço e o posicionamento da barra foram feitas fôrmas de madeira. Para cada tubo foram feitas duas fôrmas iguais de madeira, uma para cada extremidade. A princípio queria-se grautear na direção horizontal, tentando reproduzir mais fielmente a situação real do problema, por isso havia dois furos em cada fôrma, um para a barra e o outro para entrada do graute, numa extremidade, e saída do mesmo e do ar, na outra extremidade, para que assim fosse verificado o completo preenchimento do tubo. Mas, em virtude das pequenas e insuficientes dimensões para a passagem do graute, isso não foi possível e o grauteamento foi na direção vertical. Para isso, retirou-se a fôrma de uma extremidade pela qual foi injetado o graute e o furo destinado à saída do graute da outra fôrma foi fechado com mastique para evitar a saída do graute (Figura 3.12).

$\mathrm{O}$ adensamento foi feito com uma vareta de aço (Figura 3.12-b). Foi colocado silicone entre o tubo e a fôrma de madeira para vedamento. Após um dia da moldagem, as emendas foram desmoldadas e em seguida armazenadas até a data do ensaio.

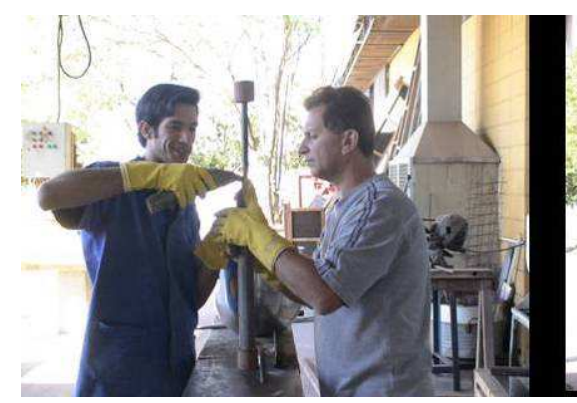

(a)

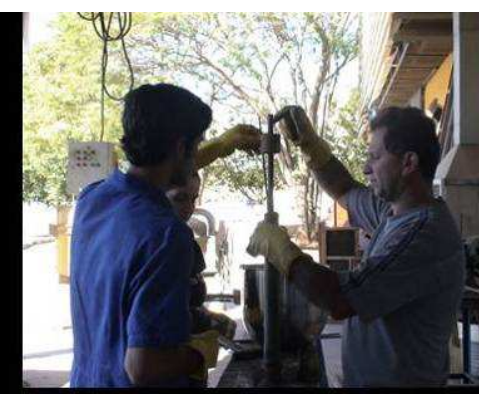

(b)

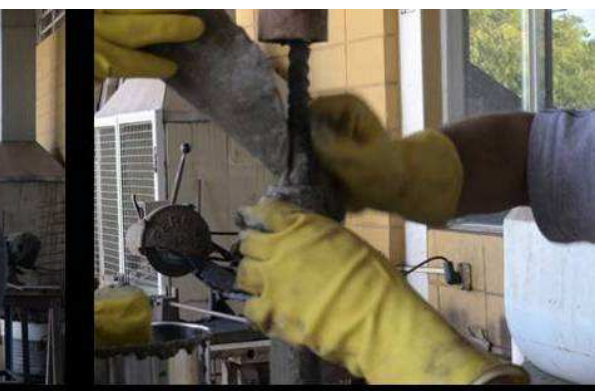

(c)

Figura 3.12 - Grauteamento a) Colocação do graute na horizontal, b) Adensamento com vareta e c) detalhe

\subsubsection{Execução do ensaio}

Os ensaios foram realizados aos três dias de moldagem, com a solicitação das barras no mesmo sentido do grauteamento, ou seja, na vertical.

O cronograma seguido para preparação do primeiro ensaio está mostrado na Tabela 3.4 .

Tabela 3.4 - Cronograma da série piloto

\begin{tabular}{cc}
\hline Etapa & Idade do graute \\
\hline Moldagem das emendas & - \\
Ensaio das emendas & 3 dias \\
Ensaio dos 3 corpos-de-prova à compressão & 3 dias \\
Ensaio dos 3 corpos-de-prova para cálculo do módulo de elasticidade & 7 dias \\
\hline
\end{tabular}


A instrumentação utilizada foi de dois transdutores de deslocamento com curso de 20 $\mathrm{mm}$, um em cada extremidade da barra, para medir o deslizamento da barra em relação ao tubo (Figura 3.13).

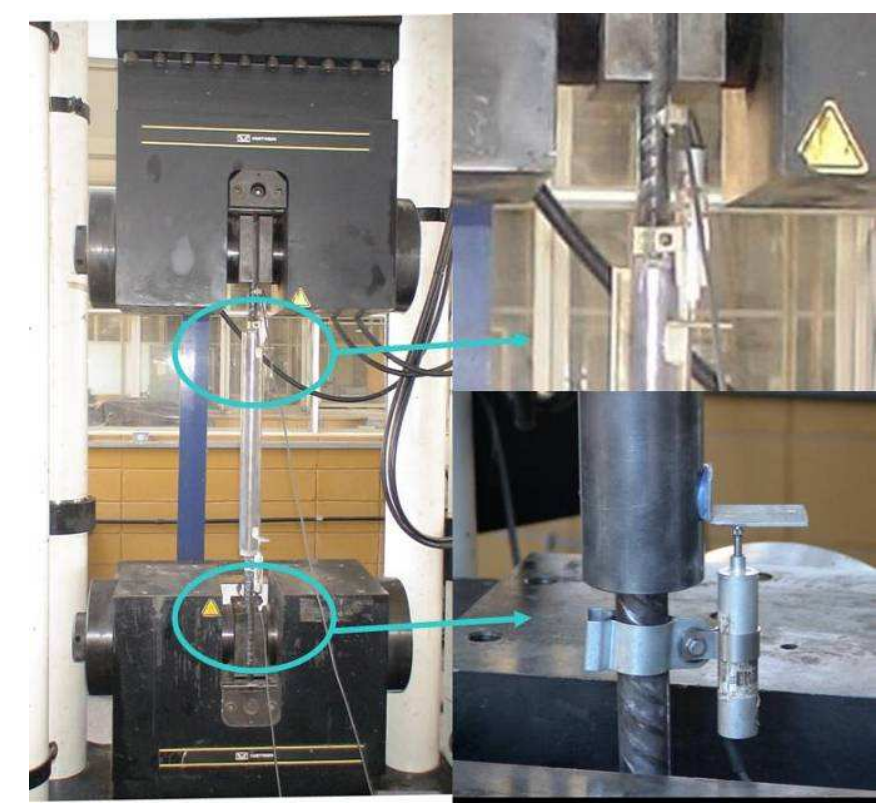

Figura 3.13 - Instrumentação com detalhe do transdutor de deslocamento superior (extremidade de carga) e inferior (extremidade de reação)

Pretendia-se também, para uma melhor verificação do comportamento da emenda, colocar transdutores de deslocamento que pudessem medir o deslizamento relativo entre 0 graute e o tubo, mas por causa das dimensões pequenas isso não foi possível.

Para a série piloto não houve variação do carregamento, sendo utilizado a ação monotônica.

Foram ensaiadas oito emendas com variados diâmetros de barra (16 mm, $20 \mathrm{~mm}$ e $25 \mathrm{~mm}$ ) e de tubo de aço ( $\varnothing_{\text {int }}=33 \mathrm{~mm}, 44 \mathrm{~mm}$ e $48 \mathrm{~mm}$ e $\varnothing_{\text {ext }}=44,5 \mathrm{~mm}, 50 \mathrm{~mm}$ e $60 \mathrm{~mm}$, respectivamente) e conformação superficial do tubo (liso ou corrugado) (Figura 3.14).

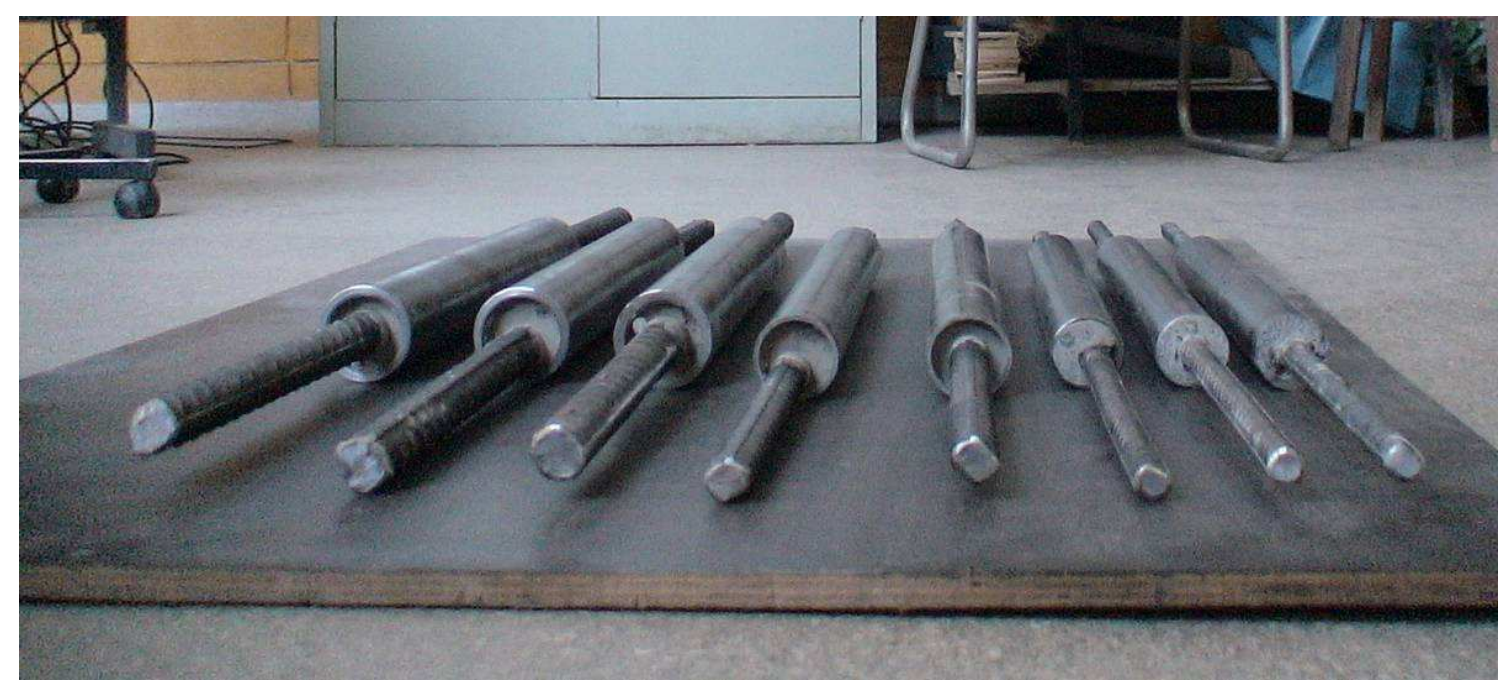

Figura 3.14 - Emendas com variados diâmetros de tubo e barra de aço 
A Tabela 3.5 apresenta a nomenclatura e o resumo das propriedades geométricas das emendas ensaiadas, constituintes do ensaio piloto.

Tabela 3.5- Resumo das propriedades gerais das emendas da série piloto

\begin{tabular}{l|c|c|c|c|c|c}
\hline Modelo & CSIT* $^{*}$ & $\begin{array}{c}\text { øbarra } \\
\mathbf{m m}\end{array}$ & $\begin{array}{c}\text { Posição } \\
\text { da barra }\end{array}$ & $\begin{array}{c}\mathbf{l b} \\
\mathbf{m m}\end{array}$ & $\begin{array}{c}\boldsymbol{\sigma}_{\text {int }} \\
\mathbf{m m}\end{array}$ & $\begin{array}{c}\text { espessura } \\
\mathbf{m m}\end{array}$ \\
\hline TC25-C & corrugado & 25 & centralizada & $8 \varnothing$ & $2 \varnothing$ & 6 \\
TL25-C & liso & 25 & centralizada & $8 \varnothing$ & $2 \varnothing$ & 6 \\
TC25-E & corrugado & 25 & encostada & $8 \varnothing$ & $2 \varnothing$ & 6 \\
TL20-C & liso & 20 & centralizada & $10 \varnothing$ & $2 \varnothing$ & 3 \\
TL20-E & liso & 20 & encostada & $10 \varnothing$ & $2 \varnothing$ & 3 \\
TL16-C & liso & 16 & centralizada & $12,5 \varnothing$ & $2 \varnothing$ & 6 \\
TC16-C & corrugado & 16 & centralizada & $12,5 \varnothing$ & $2 \varnothing$ & 6 \\
TC16-E & corrugado & 16 & encostada & $12,5 \varnothing$ & $2 \varnothing$ & 6 \\
\hline
\end{tabular}

${ }^{*}$ Conformação Superficial interna do tubo

Sendo que "TC" e "TL" correspondem à conformação superficial interna do tubo (Liso ou Corrugado), o número seguinte corresponde ao diâmetro da barra (25 mm, 20 mm e 16 $\mathrm{mm}$ ) e, "C" e "E" correspondem à posição da barra em relação ao tubo (Centralizada ou Excêntrica), da seguinte maneira:

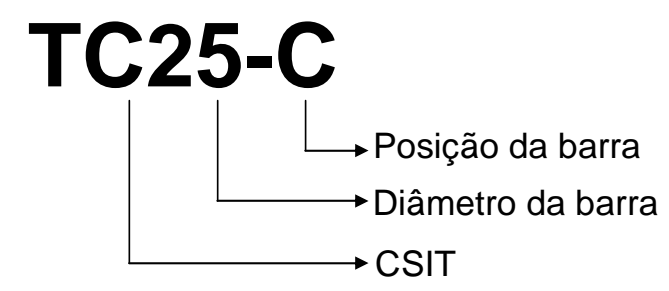

É importante salientar que foram ensaiadas emendas com barras de aço de $20 \mathrm{~mm}$ apenas com tubo liso em função do material doado ter espessura de parede insuficiente para se corrugar.

\subsection{Série Definitiva}

A partir do ensaio piloto foram estabelecidas outras variáveis para a série definitiva, verificando suas relevâncias para assim poder avaliar melhor o desempenho da emenda. Também, a partir de problemas e dificuldades observadas durante a execução do piloto, foram alterados outros detalhes como a fôrma e o grauteamento para a série definitiva. 


\subsubsection{Moldagem das emendas}

Por causa do pequeno espaço e conseqüente impossibilidade da passagem do graute por furos na fôrma de madeira, foi feito um furo em apenas um dos lados do tubo de aço (Figura 3.15), no caso em uma emenda, para poder obter melhores resultados no lado não furado, devido às perturbações causadas pelo furo. O grauteamento se deu na horizontal sendo o graute injetado por este furo, tentando assim reproduzir mais fielmente a situação real.

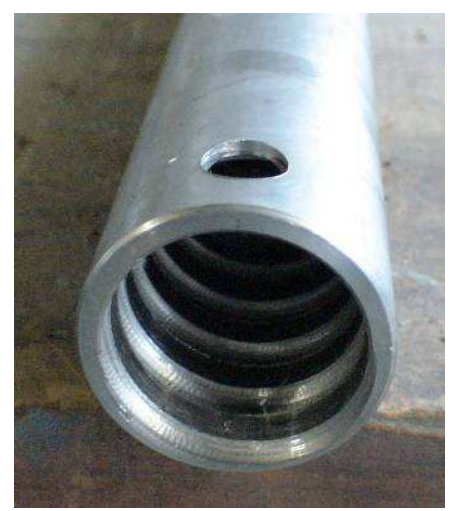

(a)

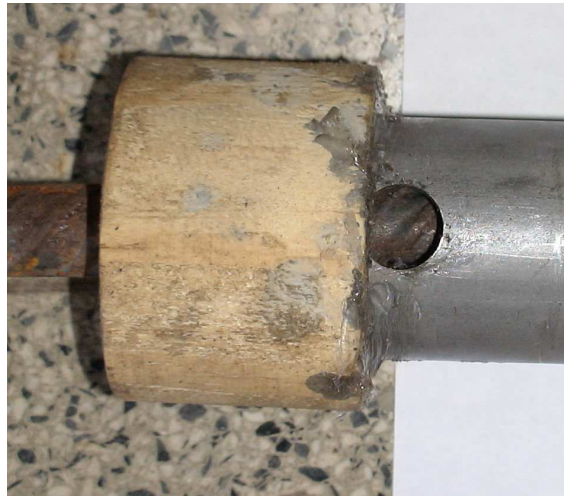

(b)

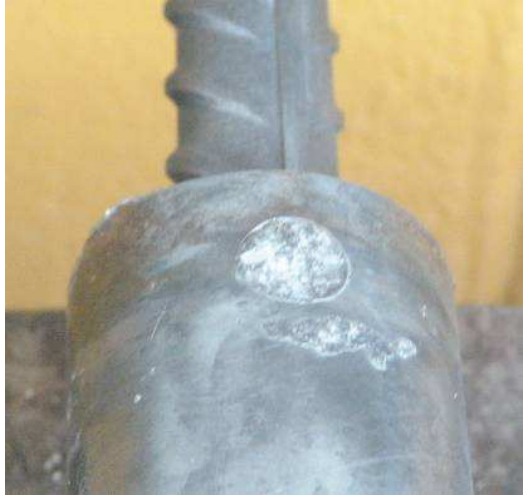

(c)

Figura 3.15 - Furo no tubo de aço a) vazio, b) com fôrma e c) após moldagem

Para este caso a fôrma da extremidade que continha o furo no tubo só possuía um furo na madeira que era para a barra de aço. Já a fôrma da outra extremidade, possuía dois furos, um para a barra e outro para a saída do graute, como a fôrma inicial do ensaio piloto. Neste furo para saída do graute era colocada uma mangueira transparente para melhor canalização e visualização da saída de ar e do graute, e consequente verificação do completo preenchimento do tubo. $\mathrm{O}$ adensamento foi feito com algumas batidas no tubo com uma colher de pedreiro. Foi colocado silicone entre o tubo e a fôrma de madeira para vedamento. Após um dia da moldagem, as emendas foram desmoldadas e em seguida armazenadas até a data do ensaio (Figura 3.16). 

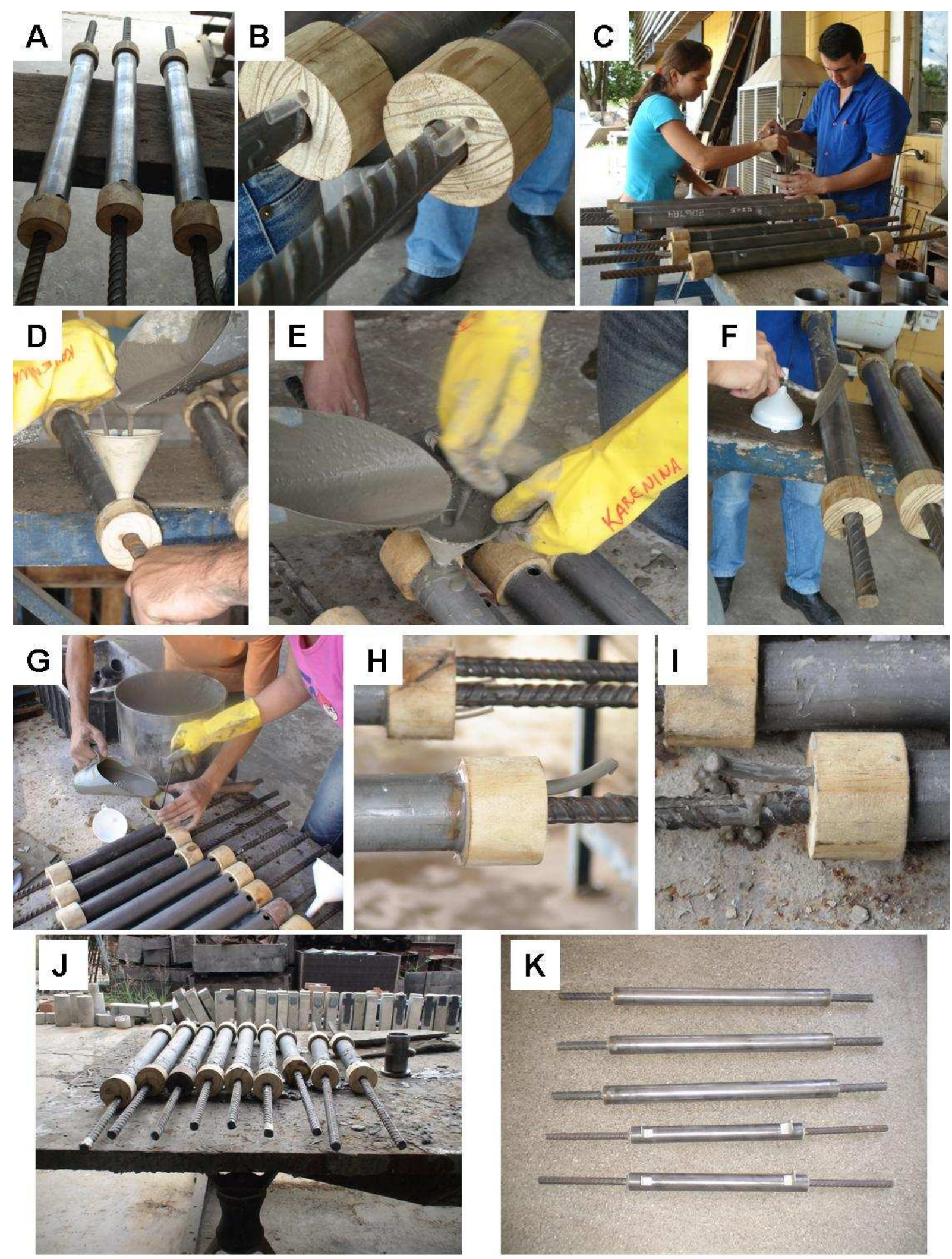

Figura 3.16 - Moldagem das emendas: A) e B) emendas com fôrmas; C),D),E) e G) injeção do graute; F)adensamento; H) e I) saída do graute; J) fim da moldagem; e K) emendas desmoldadas e limpas 


\subsubsection{Execução do ensaio}

Foram ensaiadas 21 emendas com variados tipos de ação (monotônica ou cíclica), diâmetros de barra $(16 \mathrm{~mm}, 20 \mathrm{~mm}$ e $25 \mathrm{~mm})$ e de tubo de aço $\left(\varnothing_{\text {int }}=35 \mathrm{~mm}, 38 \mathrm{~mm}\right.$ e 47 $\mathrm{mm}$ e $\varnothing_{\text {ext }}=45 \mathrm{~mm}, 50 \mathrm{~mm}$ e $57 \mathrm{~mm}$, respectivamente).

A partir do ensaio piloto confirmou-se a importância da rugosidade interna do tubo e, por isto, para o ensaio definitivo não houve emenda com conformação superficial interna do tubo lisa, apenas corrugada.

Por causa da disponibilidade de tempo e material o ensaio definitivo foi dividido em três séries: 1, 2 e 3. A solicitação das barras continuou na vertical, só que neste caso na direção perpendicular ao grauteamento, pois para esta fase conseguiu-se grautear na horizontal, tentando reproduzir mais fielmente a situação real em obra.

A Tabela 3.6 apresenta a nomenclatura e o resumo das propriedades geométricas das emendas ensaiadas constituintes do ensaio definitivo, onde na posição da barra $C$ corresponde à barra de aço centralizada e E corrresponde à barra de aço excêntrica.

Tabela 3.6 - Resumo das características gerais das emendas

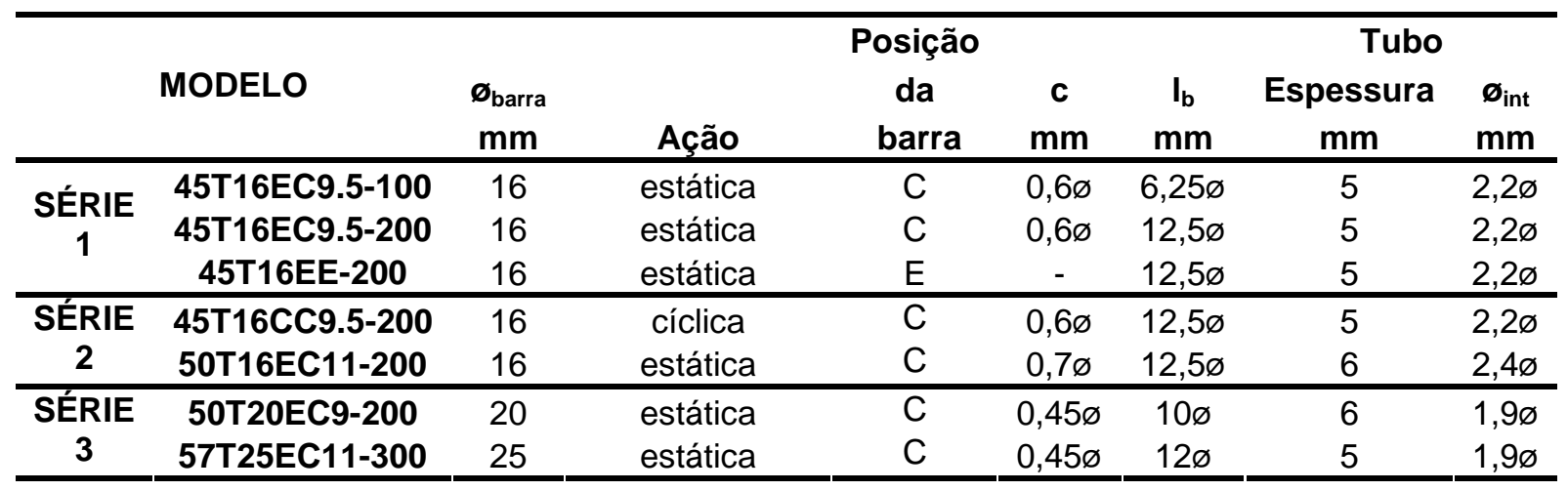

Sendo que cada caractere corresponde ao seguinte:

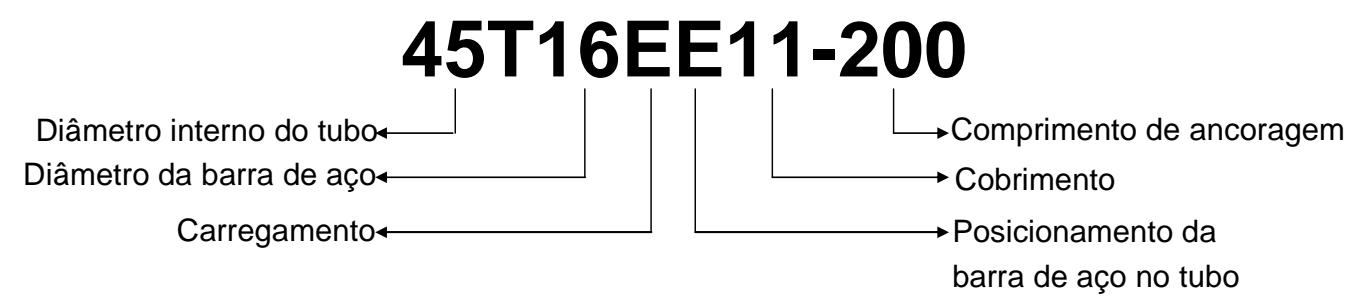

A instrumentação utilizada para todas as emendas foi de dois transdutores de deslocamento com curso de $20 \mathrm{~mm}$, um em cada extremidade da barra (Figura 3.12), como no ensaio piloto, para medir o deslizamento da barra em relação ao tubo. Para três emendas específicas, 45T16EC9.5-200, 45T16EE-200 e 45T16CC9.5-200, além dos transdutores de deslocamento foram utilizados 20 extensômetros elétricos de resistência de $5 \mathrm{~mm}$ em cada 
amostra por emenda. Eles foram distribuídos conforme a Figura 3.17 para as emendas 45T16EC9.5-200 e 45T16CC9.5-200 e distribuídas conforme a Figura 3.19 para a emenda 45T16EE-200. (Figuras 3.18, 3.20, 3.21 e 3.22)

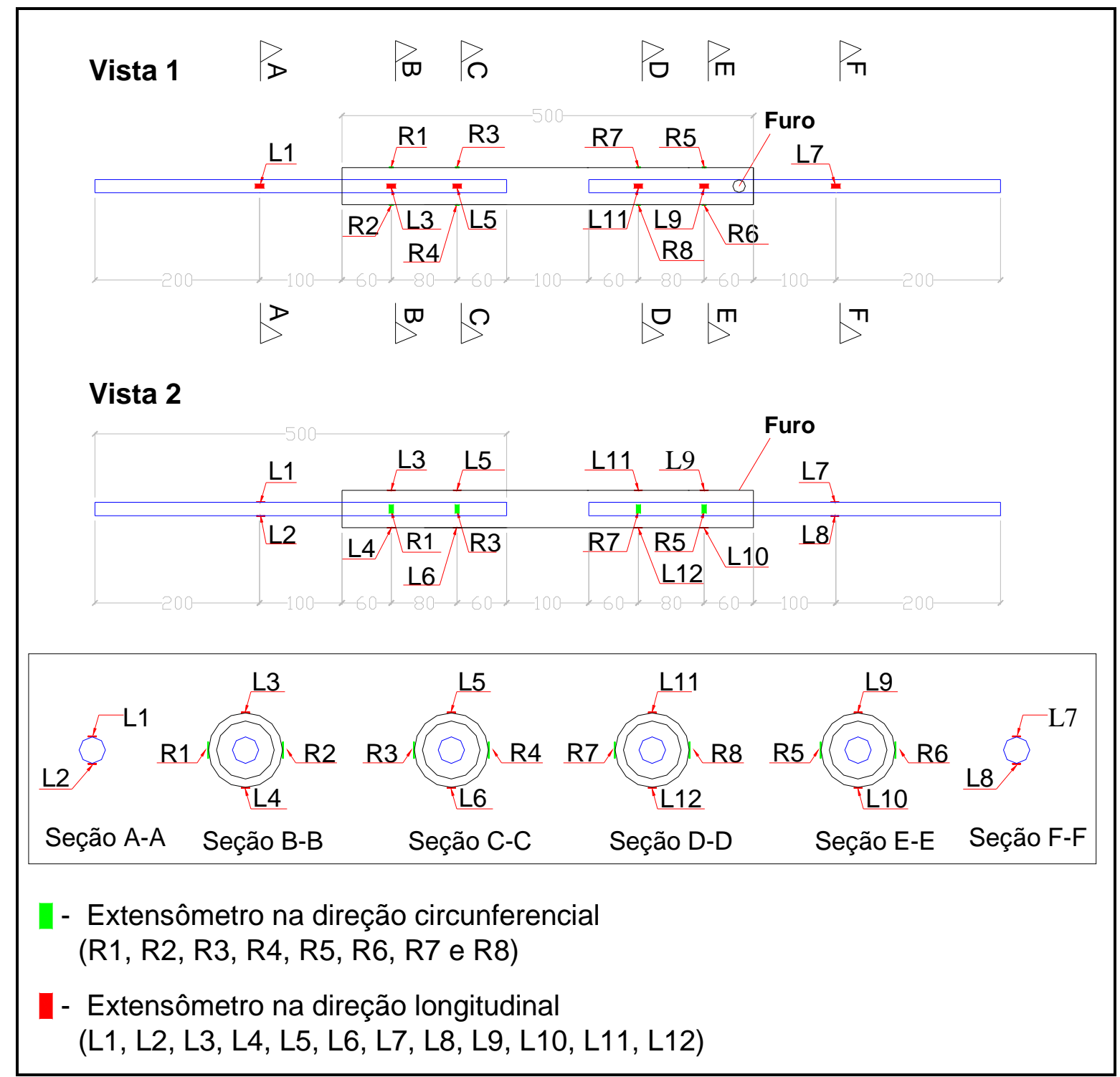

Figura 3.17 - Posicionamento dos extensômetros nas emendas 45T16EC9.5-200 e 45T16CC9.5-200

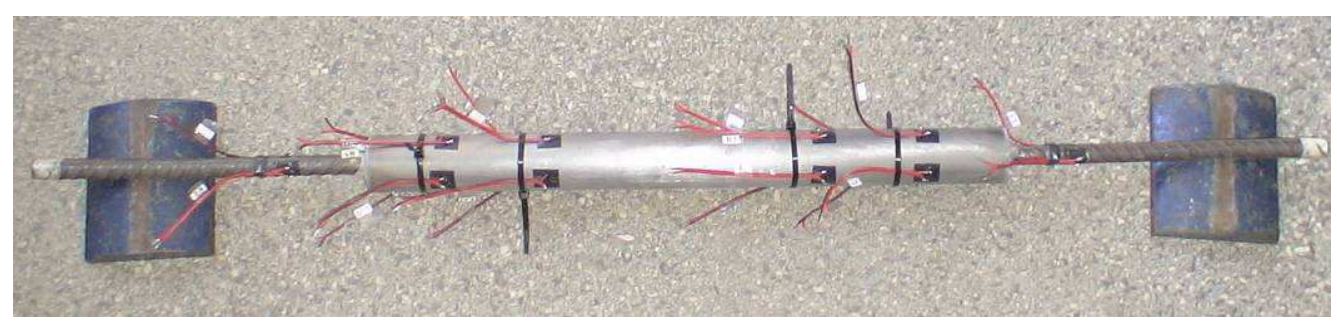

Figura 3.18 - Emenda com extensômetros 


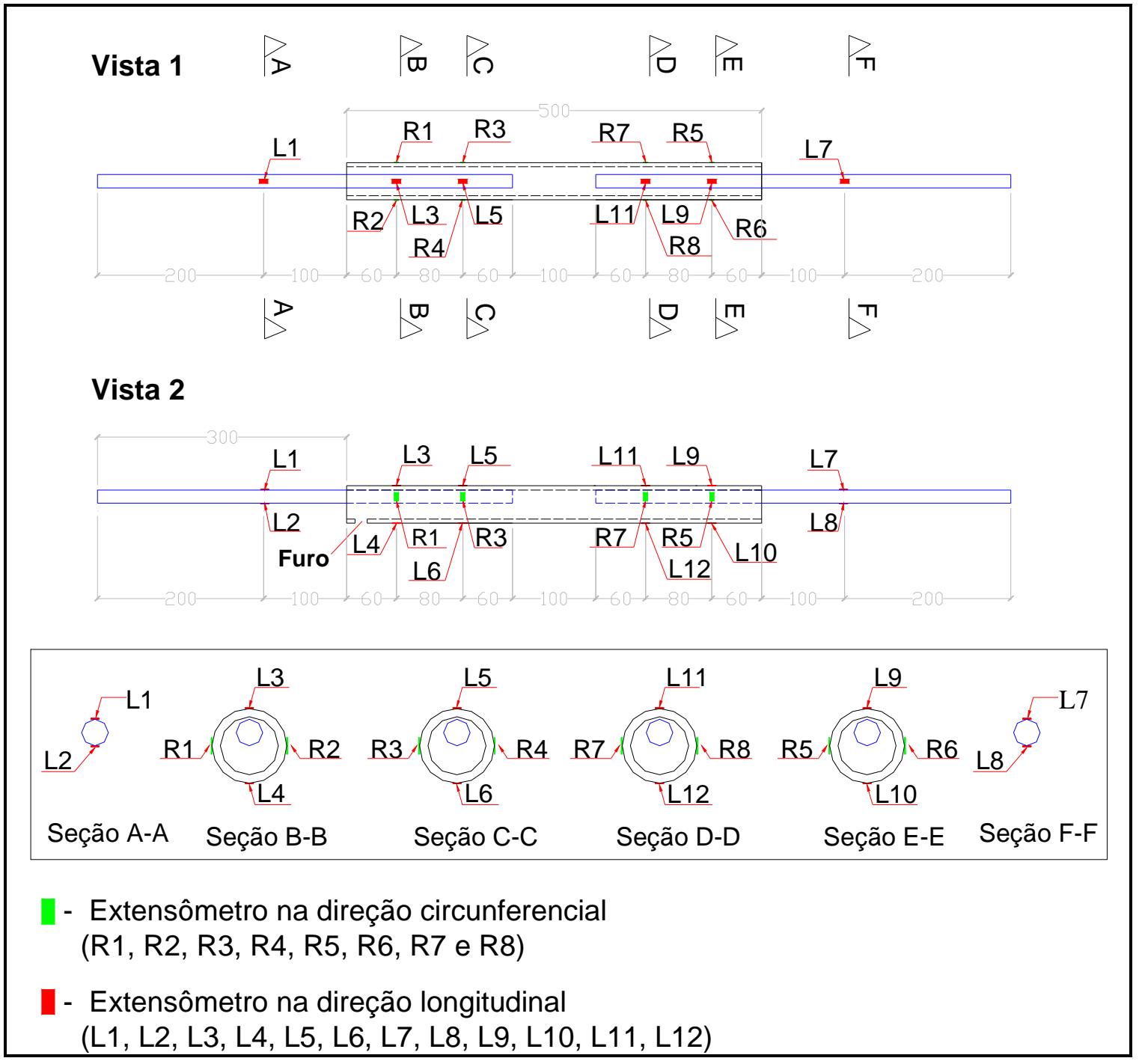

Figura 3.19 - Posicionamento dos extensômetros na emenda 45T16EE-200

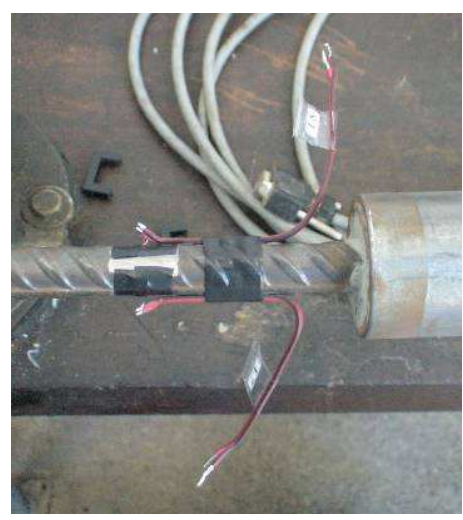

(a)

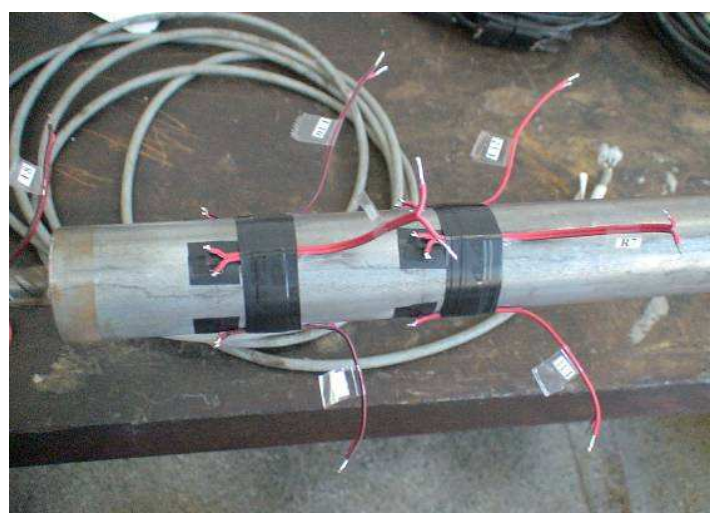

(b)

Figura 3.20 - Extensômetros a) na barra de aço e b) no tubo de aço 


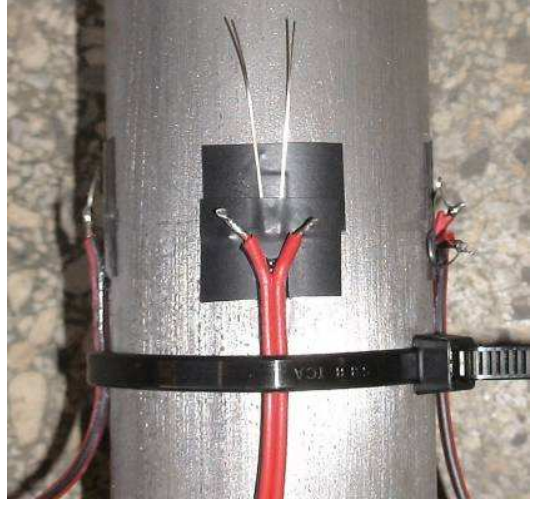

(a)

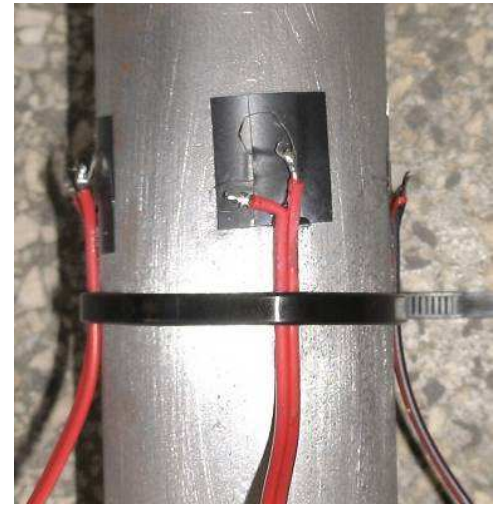

(b)

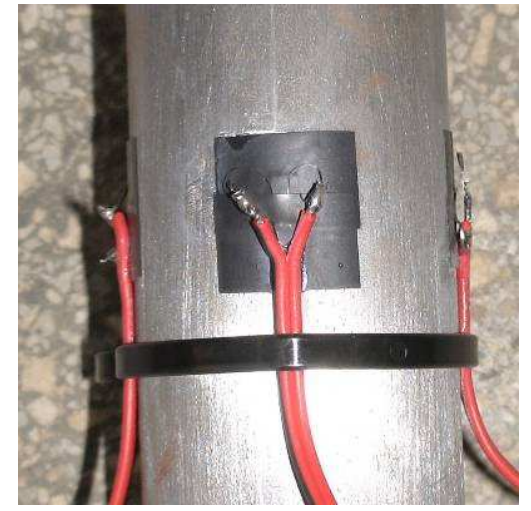

(c)

Figura 3.21 - Detalhe de extensômetros a) antes de conectar o fio do extensômetro ao fio transmissor, b) extensômetro circunferencial conectado e c) extensômetro longitudinal conectado

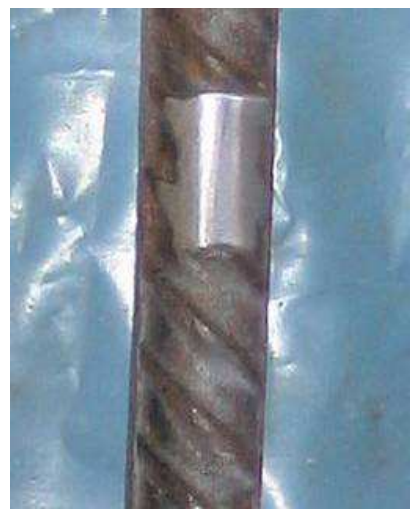

(a)

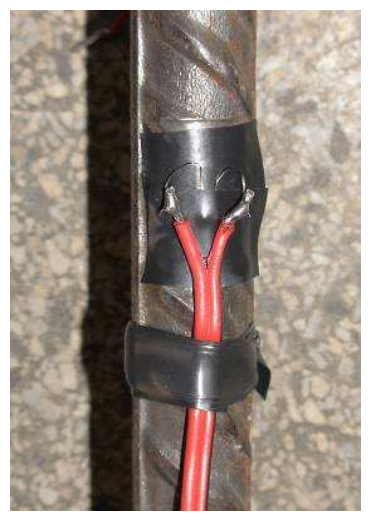

(b)

Figura 3.22 - Detalhe da barra de aço a) lixada para colar o extensômetro e b) com o extensômetro colado

Pretendiam-se ensaiar as emendas da série definitiva com três dias de moldagem, como no ensaio piloto, e com isso representar uma situação provável de solicitação da ligação em elementos pré-moldados. Mas por causa da necessidade de mais tempo para a instrumentação, além de alguns imprevistos durante o ensaio, como parada de funcionamento da máquina, não foi possível essa data. Foram ensaiados com data um pouco superior, mas sem comprometimento dos resultados, pois a única variável que se altera com o passar dos dias é a resistência do graute, mas que por ser um graute de alta resistência inicial não há grande variação entre 3 e 7 dias após a concretagem. Isto pode ser observado no trecho A da Figura 3.23 que mostra a evolução da resistência à compressão do graute com o tempo. 


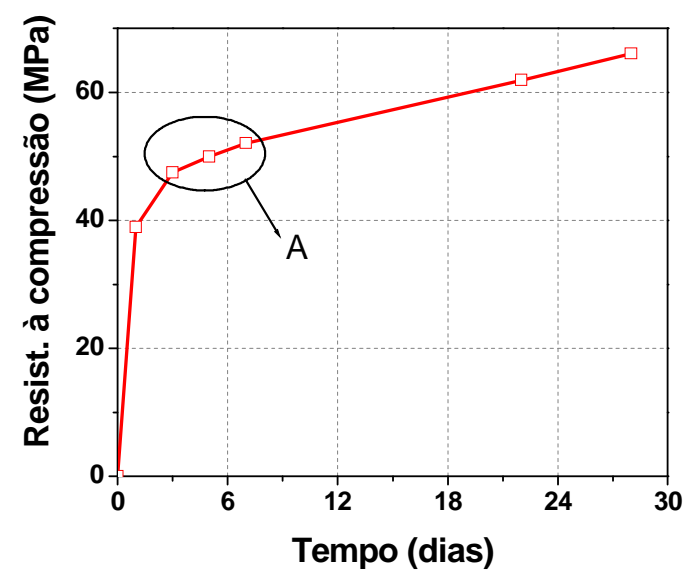

Figura 3.23 - Evolução da resistência à compressão do Masterflow ${ }^{\circledR} 885$ Grout com o tempo

As emendas da Série 1 (Figuras 3.24 e 3.25) foram ensaiadas aos 5 dias de moldagem dos modelos e os ensaios de caracterização do graute foram feitos conforme cronograma mostrado na Tabela 3.7.
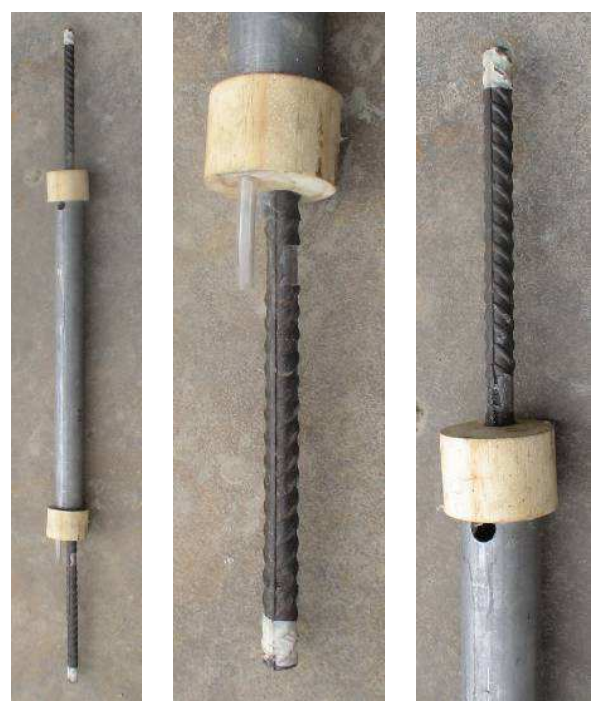

Figura 3.24 - Amostra 45T16EC9.5-200A antes da moldagem

Tabela 3.7 - Cronograma do ensaio definitivo - Série 1

\begin{tabular}{c|c}
\hline Etapa & Idade do graute \\
\hline Moldagem das emendas & - \\
Ensaio das emendas 45T16EC9.5-200 e 45T16EE-200 & 5 dias \\
Ensaio dos 3 corpos-de-prova à compressão & 5 dias \\
Ensaio das emendas 45T16EC9.5-100 & 6 dias \\
Ensaio dos 3 corpos-de-prova para cálculo do módulo de elasticidade & 6 dias \\
\hline
\end{tabular}




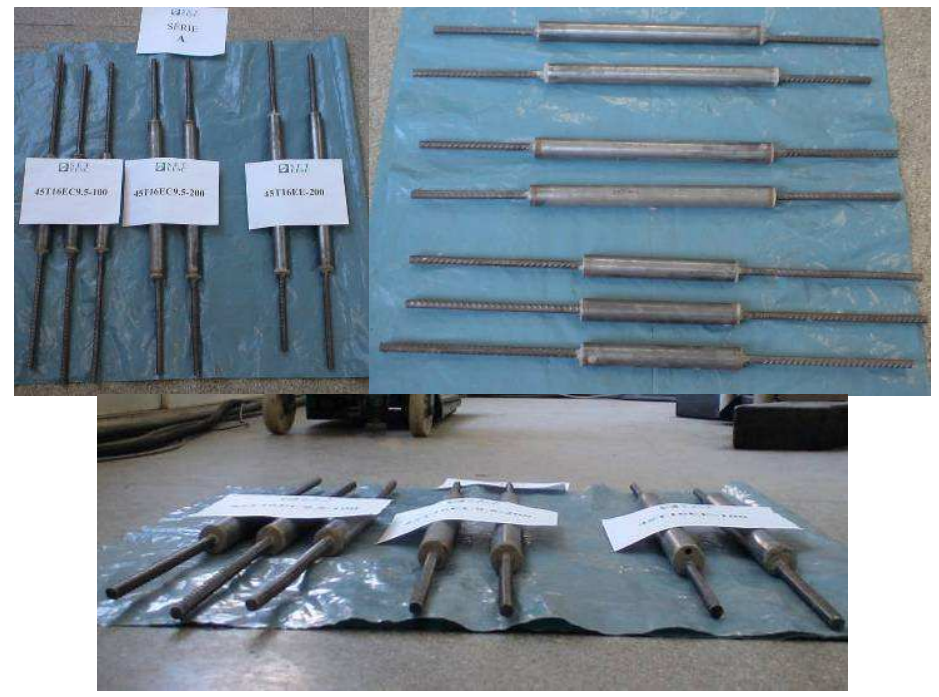

Figura 3.25 - Vistas de algumas emendas da série 1

Em todas as emendas da série 1 o furo foi posicionado na extremidade de reação.

A Figura 3.26 mostra as emendas da série 1 sendo ensaiadas.

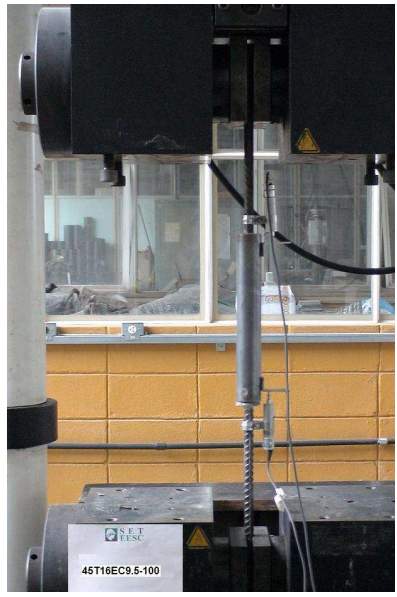

(a)

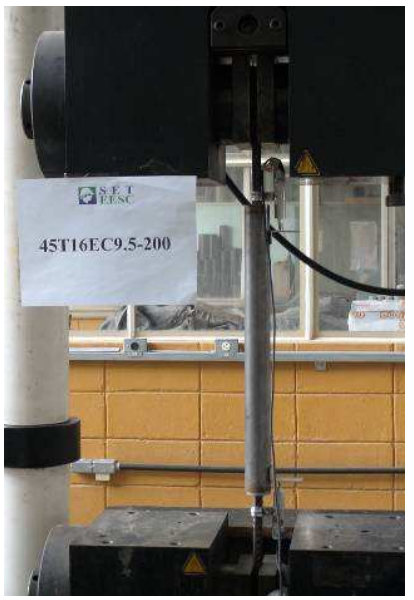

(b)

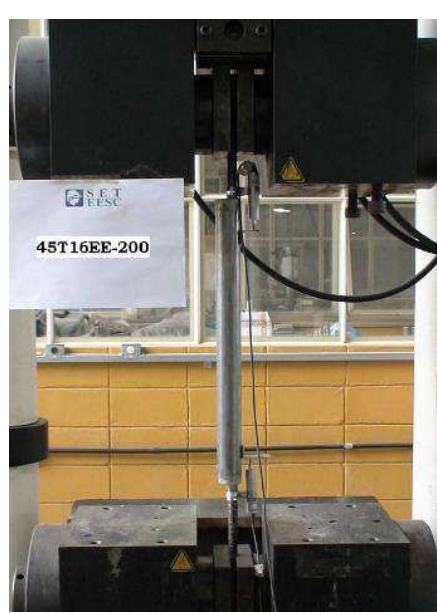

(c)

Figura 3.26 - Amostras sendo ensaiadas a) 45T16EC9.5-100, b) 45T16EC9.5-200 e c) 45T16EE-200

Entre as emendas 45T16EC9.5-200, a amostra 45T16EC9.5-200A foi instrumentada com extensômetros ao longo do tubo e da barra, além dos dois transdutores de deslocamento (Figura 3.27).

Entre as emendas 45T16EE-200, a amostra A foi instrumentada com extensômetros ao longo do tubo e da barra (Figura 3.28), além dos dois transdutores de deslocamento como nas outras emendas (Figura 3.29). 


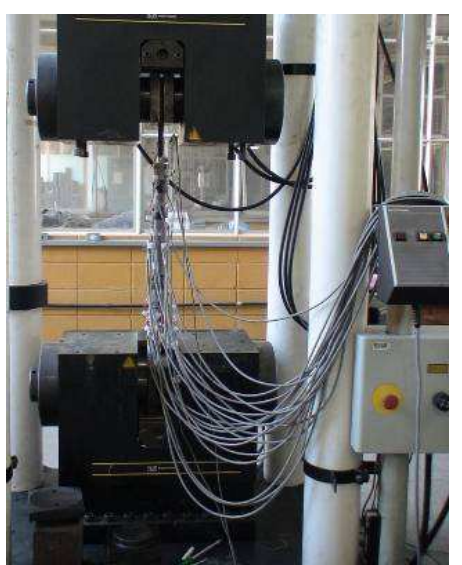

(a)

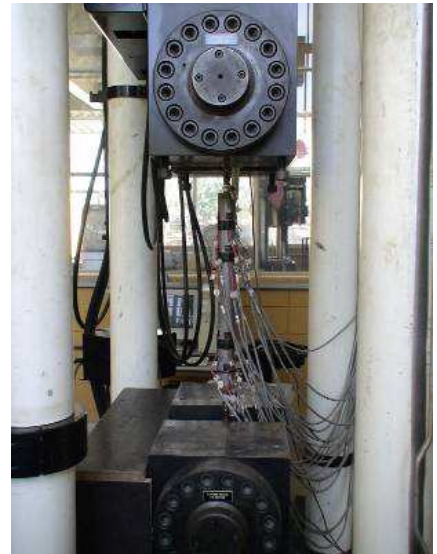

(b)

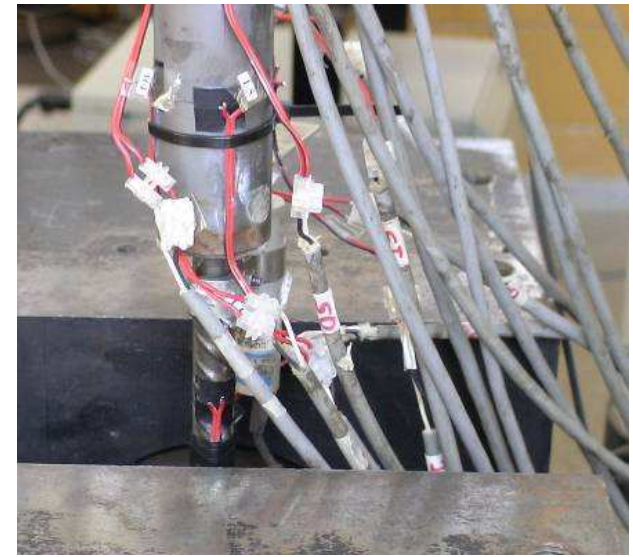

(c)

Figura 3.27 - Amostra 45T16EC9.5-200A instrumentada a) vista frontal, b) vista lateral e c) detalhe da extremidade de reação

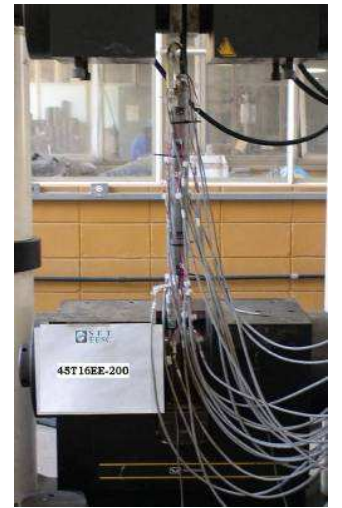

(a)

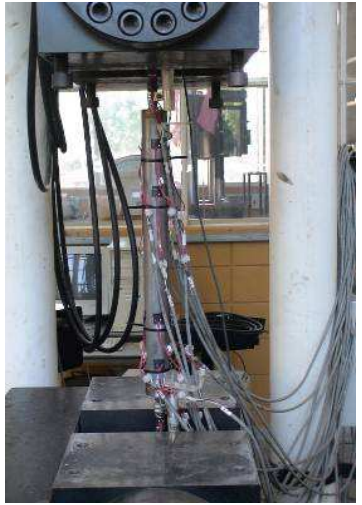

(b)

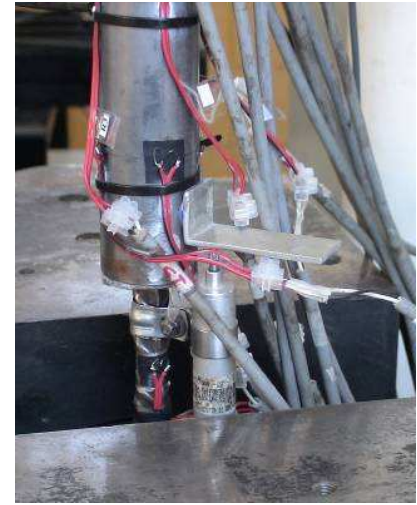

(c)

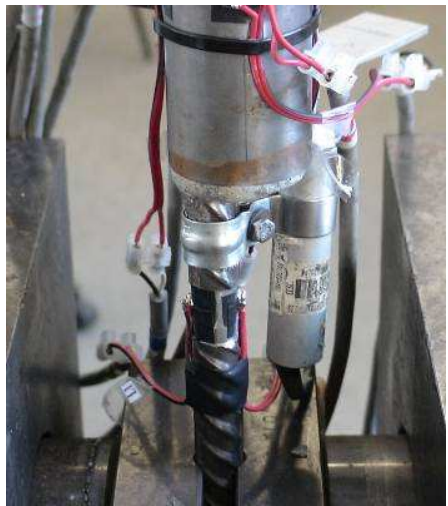

(d)

Figura 3.28 - Amostra 45T16EE-200A instrumentado a) vista frontal, b) vista lateral e c) e d) detalhe da extremidade de reação

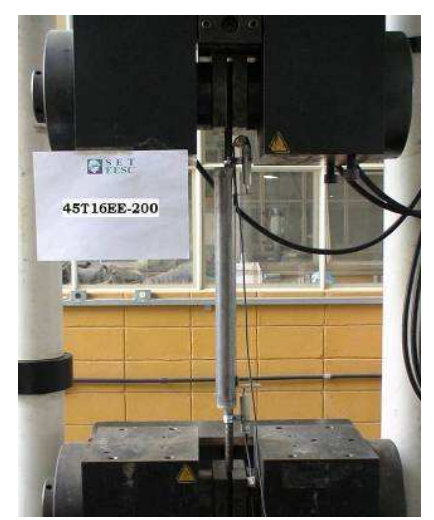

(a)

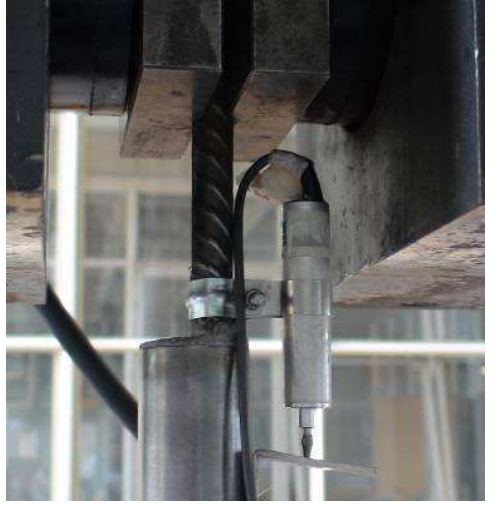

(b)

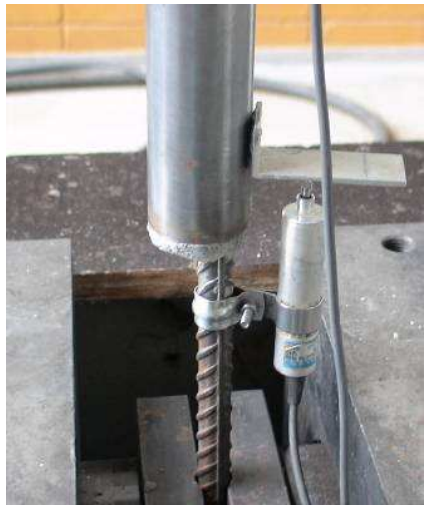

(c)

Figura 3.29 - Amostra 45T16EC9.5-200B a) geral, b) transdutor de deslocamento da extremidade de carga e c) transdutor de deslocamento da extremidade de reação 
As emendas da Série 2 (Figuras 3.30, 3.31 e 3.32) foram ensaiadas aos 6 dias de moldagem dos corpos-de-prova e os ensaios de caracterização do graute foram feitos conforme cronograma mostrado na Tabela 3.8.

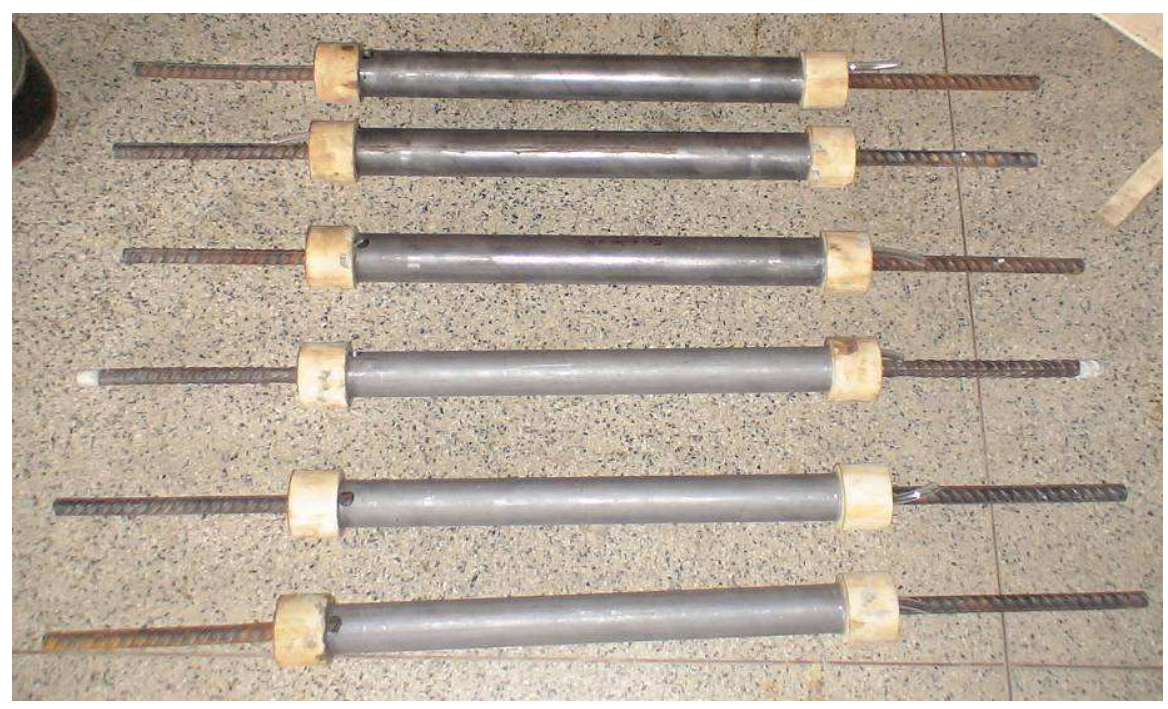

Figura 3.30- Emendas da série 2 preparadas para serem moldadas

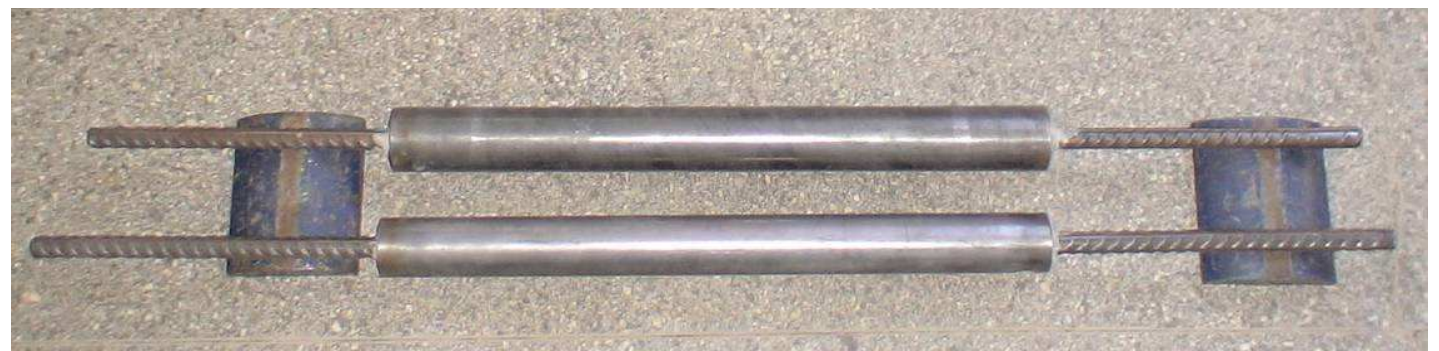

Figura 3.31- Vista de cima das emendas 45T16CC9.5-200 e 50T16EC11-200

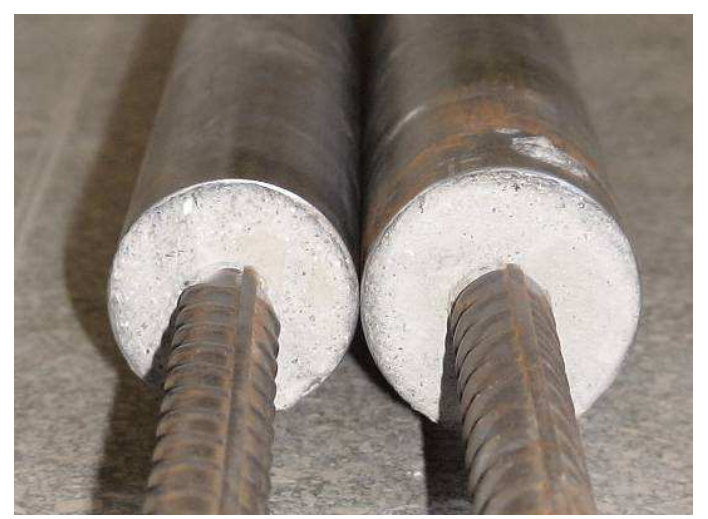

(a)

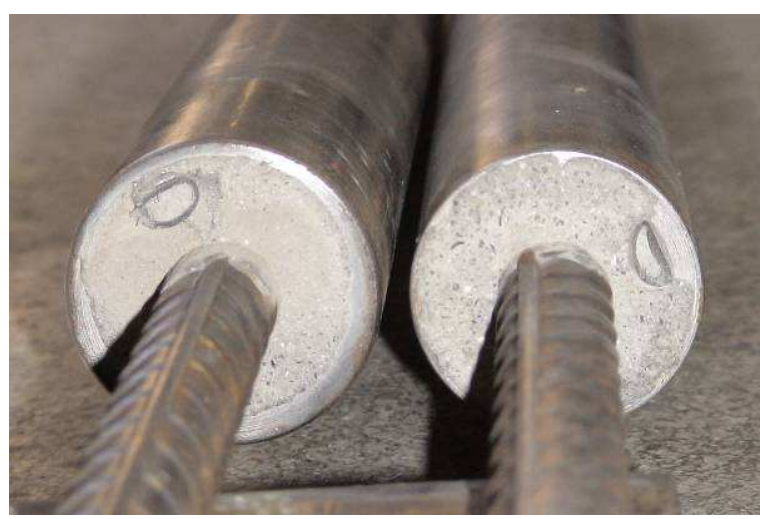

(b)

Figura 3.32- Vista da extremidade a) com furo e b) sem furo 
Tabela 3.8 - Cronograma do ensaio definitivo - Série 2

\begin{tabular}{c|c}
\hline Etapa & Idade do graute \\
\hline Moldagem das emendas & - \\
Ensaio das emendas 45T16CC9.5-200 e 50T16EC11-200 & 6 dias \\
Ensaio dos 3 corpos-de-prova à compressão & 6 dias \\
Ensaio dos 3 corpos-de-prova para cálculo do módulo de elasticidade & 6 dias \\
\hline
\end{tabular}

Apenas na amostra C da emenda 50T16EC11-200, o furo foi posicionado na extremidade de aplicação de força, para verificar a sua influência na ruína.

A Figura 3.33 mostra as emendas sendo ensaiados desta série.

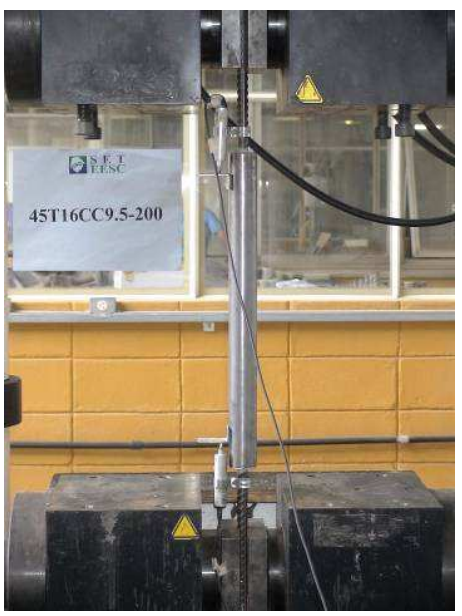

(a)

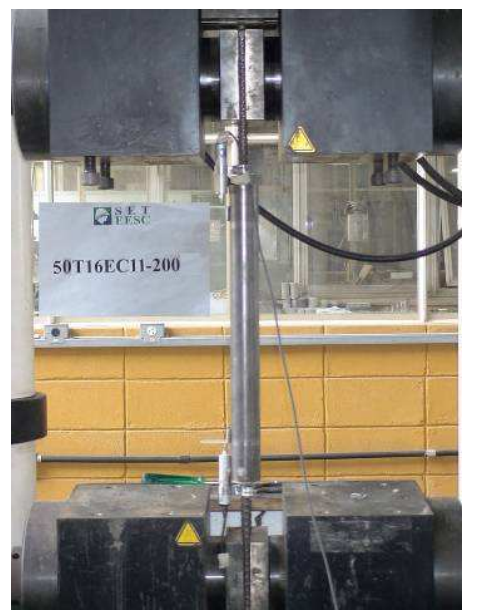

(b)

Figura 3.33 - Emendas sendo ensaiadas a) 45T16CC9.5-200 e b) 50T16EC11-200

Entre as emendas 45T16CC9.5-200, a amostra 45T16CC9.5-200C foi instrumentada com extensômetros ao longo do tubo e da barra, além dos dois transdutores de deslocamento. (Figura 3.34)

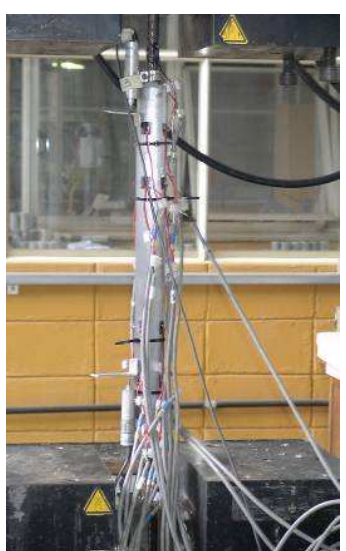

(a)

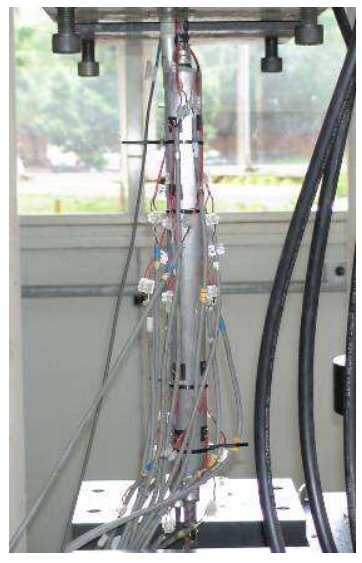

(b)

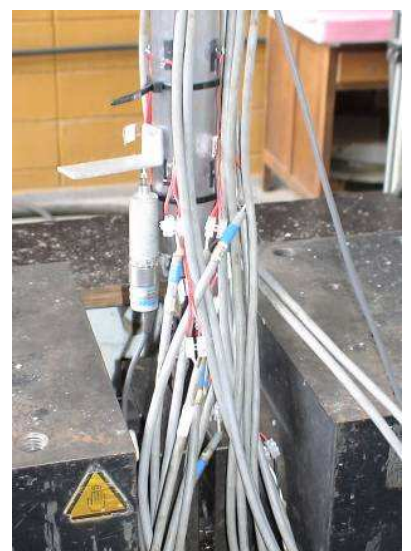

(c)

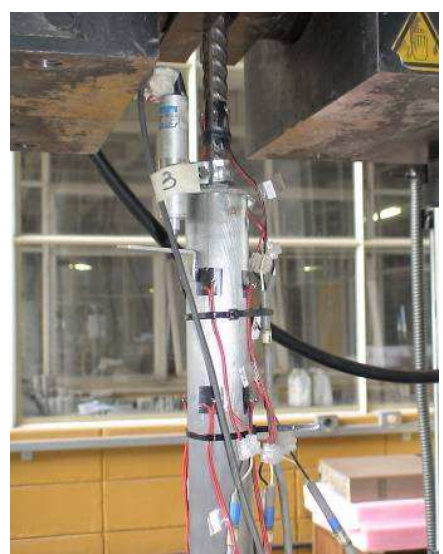

(d)

Figura 3.34 - Amostra 45T16CC9.5-200C instrumentada a) vista frontal, b) vista lateral, c) detalhe da extremidade de reação e d) detalhe da extremidade de carga 
As emendas da Série 3 (Figura 3.35) foram ensaiadas aos 4 dias de moldagem e os ensaios de caracterização do graute foram feitos conforme cronograma mostrado na Tabela 3.9 .
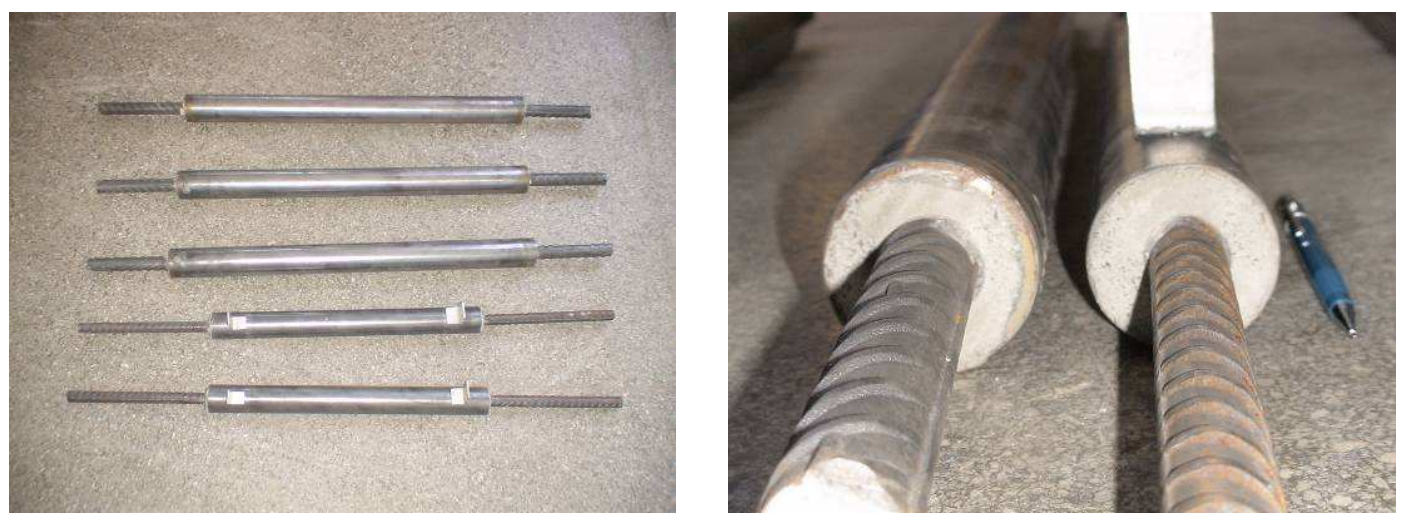

Figura 3.35- Emendas da série 3

Tabela 3.9 - Cronograma do ensaio definitivo - Série 3

\begin{tabular}{c|c}
\hline Etapa & Idade do graute \\
\hline Moldagem das emendas & - \\
Ensaio das emendas 50T20EC9-200 e 57T25EC11-300 & 4 dias \\
Ensaio dos 3 corpos-de-prova à compressão & 4 dias \\
Ensaio dos 3 corpos-de-prova para cálculo do módulo de elasticidade & 4 dias \\
\hline
\end{tabular}

A Figura 3.36 mostra as emendas sendo ensaiadas desta série.

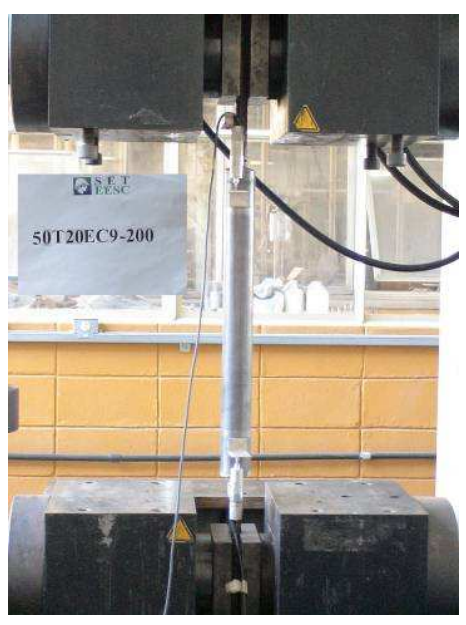

(a)

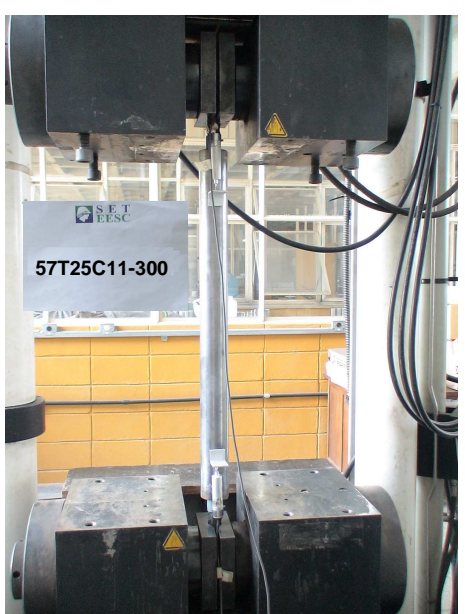

(b)

Figura 3.36 - Emendas sendo ensaiadas a) 50T20EC9-200 e b) 57T25EC11-300 


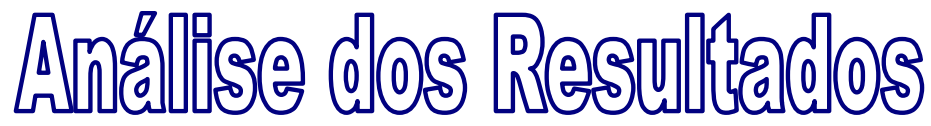

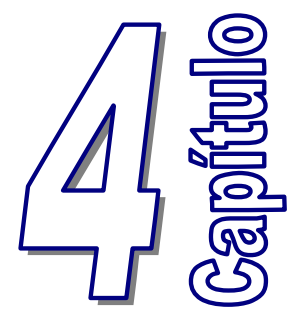

Neste capítulo são analisados e discutidos os resultados obtidos por meio da investigação experimental. Os resultados experimentais são comparados entre si para analisar a influência da corrugação do tubo, do diâmetro e posicionamento da barra de aço, da ação do comprimento de ancoragem.

\subsection{Definição do graute utilizado}

Na tabela 4.1 estão indicadas as resistências à compressão $\left(f_{c}\right)$ de cada graute.

Tabela 4.1 - Resistência à compressão dos grautes

\begin{tabular}{cccc}
\hline & \multicolumn{3}{c}{$\mathbf{f}_{\mathrm{c}}$ (MPa) } \\
Graute & $\mathbf{2 4 h}$ & $\mathbf{3}$ dias & $\mathbf{2 8}$ dias \\
\hline V1 & 26,1 & 42,2 & 64,5 \\
V2 & 19,7 & 35,2 & 42,9 \\
M1 & 38,9 & 45,6 & 59,4 \\
M2 & 20,7 & 49,9 & 41,1 \\
\hline
\end{tabular}

A partir destes resultados optou-se pela utilização do Masterflow ${ }^{\circledR} 885$ Grout (M1) por ter atingido alta resistência (45,6 MPa) para a data requisitada (3 dias) e boas condições de manuseio e trabalho, além de uma boa evolução na resistência.

\subsection{Caracterização do Graute e do Aço}

As propriedades físicas e mecânicas dos materiais e de seus constituintes, entre outras, têm grande influência na resistência da emenda.

$\mathrm{Na}$ tabela 4.2 estão indicados os valores de resistência à compressão $\left(\mathrm{f}_{\mathrm{c}}\right)$ obtidos nos três corpos-de-prova cilíndricos de medidas $10 \mathrm{~cm} \times 20 \mathrm{~cm}$, ensaiados aos três dias de moldagem, bem como o valor adotado que é o maior dos três, e o módulo de elasticidade longitudinal $\left(E_{c}\right)$, obtidos dos dois corpos-de-prova cilíndricos de medidas $10 \mathrm{~cm} \times 20 \mathrm{~cm}$, ensaiados aos sete dias de moldagem, correspondentes à série piloto. 
Tabela 4.2 - Resistências à compressão e módulos de elasticidade do graute para o ensaio piloto

\begin{tabular}{ccccc}
\hline & $\mathbf{C P - 1}$ & $\mathbf{C P - 2}$ & $\mathbf{C P - 3}$ & $\mathbf{f}_{\mathrm{c}, \text { máx }}$ \\
\hline $\mathbf{f}_{\mathrm{c}}(\mathrm{MPa})$ & 47,5 & 42,7 & 46,5 & 47,5 \\
$\mathrm{E}_{\mathrm{c}}(\mathbf{M P a})$ & 25431 & 22729 & - & - \\
\hline
\end{tabular}

$\mathrm{Na}$ tabela 4.3 estão indicados os valores de resistência à compressão $\left(\mathrm{f}_{\mathrm{c}}\right)$ obtidos nos três corpos-de-prova cilíndricos de medidas $10 \mathrm{~cm}$ x $20 \mathrm{~cm}$, ensaiados aos cinco dias de moldagem, bem como o valor adotado que é o maior dos três, e o módulo de elasticidade longitudinal $\left(E_{c}\right)$, obtidos dos três corpos-de-prova cilíndricos de medidas $10 \mathrm{~cm} \times 20 \mathrm{~cm}$, ensaiados aos seis dias de moldagem, bem como a média deste módulo de elasticidade, correspondentes à série 1 do ensaio definitivo.

Tabela 4.3 - Resistências à compressão e módulos de elasticidade do graute para a série 1

\begin{tabular}{cccccc}
\hline & $\mathbf{C P}-1$ & $\mathbf{C P - 2}$ & $\mathbf{C P}-3$ & $\mathbf{f}_{\mathrm{c}, \text { max }}$ & $\mathbf{E}_{\text {med }}$ \\
\hline $\mathbf{f}_{\mathrm{c}}(\mathrm{MPa})$ & 46,9 & 47,9 & 47,4 & 47,9 & - \\
$\mathbf{E}_{\mathrm{c}}(\mathbf{M P a})$ & 23543 & 24272 & 25698 & - & 24504 \\
\hline
\end{tabular}

Na tabela 4.4 estão indicados os valores de resistência à compressão $\left(f_{c}\right)$ e do módulo de elasticidade longitudinal $\left(E_{c}\right)$ obtidos nos três corpos-de-prova cilíndricos de medidas $10 \mathrm{~cm} \times 20 \mathrm{~cm}$, ensaiados aos seis dias de moldagem, bem como o valor resistência à compressão adotado e a média do módulo de elasticidade longitudinal, correspondentes à série 2 do ensaio definitivo.

Tabela 4.4 - Resistências à compressão e módulos de elasticidade do graute para a série 2

\begin{tabular}{cccccc}
\hline & $\mathbf{C P}-1$ & $\mathbf{C P - 2}$ & $\mathbf{C P - 3}$ & $\mathbf{f}_{\mathrm{c}, \text { máx }}$ & $\mathbf{E}_{\text {med }}$ \\
\hline $\mathbf{f}_{\mathrm{c}}(\mathbf{M P a})$ & 54,1 & 52,0 & 46,9 & 54,1 & - \\
$\mathbf{E}_{\mathrm{c}}(\mathbf{M P a})$ & 22354 & 25427 & 23569 & - & 23783 \\
\hline
\end{tabular}

$\mathrm{Na}$ tabela 4.5 estão indicados os valores de resistência à compressão $\left(\mathrm{f}_{\mathrm{c}}\right)$ e do módulo de elasticidade longitudinal $\left(E_{c}\right)$ obtidos nos três corpos-de-prova cilíndricos de medidas $10 \mathrm{~cm} \times 20 \mathrm{~cm}$, ensaiados aos quatro dias de moldagem, bem como o valor de resistência à compressão adotado e a média do módulo de elasticidade longitudinal, correspondentes à série 3 do ensaio definitivo.

Tabela 4.5 - Resistências à compressão e módulos de elasticidade do graute para a série 3

\begin{tabular}{ccccccc}
\hline & $\mathbf{C P}-1$ & $\mathbf{C P - 2}$ & $\mathbf{C P - 3}$ & $\mathbf{C P}-4$ & $\mathbf{f}_{\mathrm{c}, \operatorname{máx}}$ & $\mathbf{E}_{\text {med }}$ \\
\hline $\mathbf{f}_{\mathrm{c}}(\mathbf{M P a})$ & 48,1 & 47,7 & 47,8 & 47,3 & 48,1 & - \\
$\mathbf{E}_{\mathrm{c}}(\mathbf{M P a})$ & 25235 & 25542 & 24356 & 24735 & - & 24967 \\
\hline
\end{tabular}


As considerações sobre os ensaios a realizar e procedimentos de cálculo das características do graute como resistência à compressão, módulo de elasticidade foi por meio de norma de concreto, visto que não existe norma para graute.

$\mathrm{Na}$ Tabela 4.6 estão indicados os valores médios da resistência de escoamento $\left(f_{y m}\right)$, da deformação de início de escoamento $\left(\varepsilon_{\text {ym }}\right)$, da resistência à tração $\left(f_{\text {stm }}\right)$ e de módulo de elasticidade $\left(E_{s}\right)$ de três corpos-de-prova das barras de aço para cada diâmetro de barra utilizado, $16 \mathrm{~mm}, 20 \mathrm{~mm}$ e $25 \mathrm{~mm}$.

Tabela 4.6 - Resultados médios dos corpos-de-prova das barras de aço

\begin{tabular}{cccc}
\hline $\boldsymbol{\varpi}_{\text {barra }}(\mathbf{m m})$ & $\mathbf{1 6}$ & $\mathbf{2 0}$ & $\mathbf{2 5}$ \\
\hline $\mathbf{f}_{\mathrm{ym}}(\mathbf{M P a})$ & 598 & 611 & 603 \\
$\boldsymbol{\varepsilon}_{\mathrm{ym}}(\%)$ & 3 & 3.3 & 3.3 \\
$\mathbf{f}_{\mathrm{stm}}(\mathbf{M P a})$ & 756 & 753 & 739 \\
$\mathrm{E}_{\mathbf{s}}(\mathrm{GPa})$ & 217,5 & 228,4 & 222 \\
\hline
\end{tabular}

\subsection{Parâmetros de cálculo}

Para análise dos resultados, além da força axial medida e os deslizamentos utilizados nos gráficos, foram determinados, para algumas emendas, a tensão axial e a tensão de aderência.

Para determinação da tensão axial foi utilizada a seguinte expressão:

$$
\sigma_{s}=\frac{F_{s}}{A_{s}}
$$

Sendo:

$\sigma_{\mathrm{s}}=$ tensão axial;

$\mathrm{F}_{\mathrm{s}}=$ força axial aplicada;

$\mathrm{A}_{\mathrm{s}}=$ área da barra de aço.

Para determinação da tensão de aderência, só foi considerada a parcela do engrenamento mecânico, dependente da conformação superficial das barras de aço. Esta parcela é decorrente da existência de saliências ou mossas na superfície dos elementos, que funcionam como peças de apoio aplicando forças de compressão no concreto, o que aumenta significativamente a aderência. Este efeito também é encontrado em barras lisas, pela existência das irregularidades próprias, originadas do processo de laminação, porém em escala menor. Não foi considerada a parcela corresponde ao confinamento e foi determinada pela seguinte expressão: 


$$
\tau_{a d}=\frac{F}{l_{\text {emb }} \times a_{t u b o}}
$$

Sendo:

$\tau_{\text {ad }}=$ tensão axial de aderência;

$\mathrm{F}=$ força axial aplicada;

$l_{\text {emb }}=$ comprimento de embutimento da barra de aço;

$\mathrm{a}_{\mathrm{tubo}}=$ perímetro da circunferência da barra.

\subsection{Série Piloto}

São apresentados os resultados da série piloto e sua análise, pois a partir destes foram definidas as variáveis que foram investigadas na série definitiva e levantadas algumas questões importantes com relação ao comportamento da emenda.

\subsubsection{Resultados das emendas}

A Figura 4.1 ilustra o comportamento das curvas força vs. deslizamento para as emendas TC16-C e TC16-E.
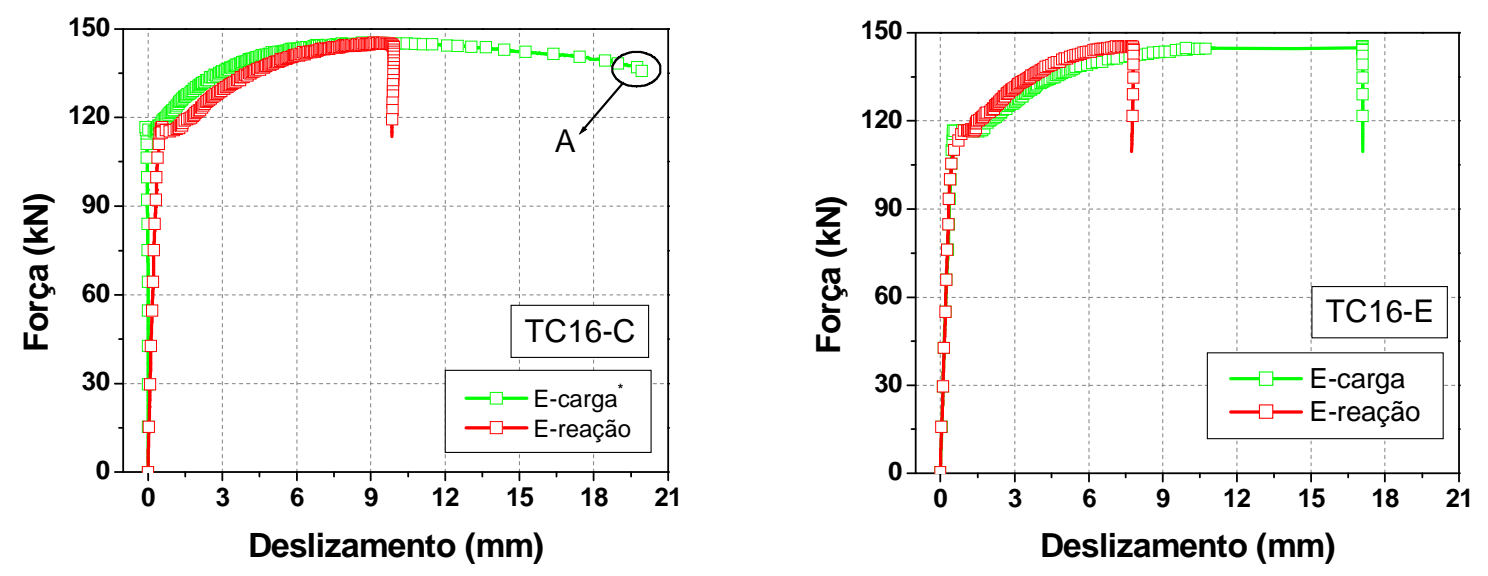

Figura 4.1 - Curva força vs. deslizamento das emendas TC16-C e TC16-E

Na Figura 4.1 observa-se um comportamento similar entre as duas extremidades das duas emendas. Após a força última ter sido atingida (145 kN e 146 kN, respectivamente para as emendas TC16-C e TC16-E), não foi admitido mais acréscimo de força, significando que foi atingido o limite máximo da capacidade da ligação e constatando a ruína por escoamento da barra de aço na extremidade de carga, enquanto que na outra extremidade de reação houve redução do valor da força aplicada, com deslizamento constante, que ocorreu por causa da perda de rigidez da outra extremidade. 
No ponto A do gráfico da emenda TC16-C, o transdutor da extremidade de carga apresentou a sua última leitura do deslizamento. Não foi possível registrar o deslizamento máximo da ligação em função da limitação do curso do transdutor utilizado (20 mm), o que comprometeu essa leitura.

No gráfico da emenda TC16-E, a partir de 10,7 mm de deslizamento, não houve mais registro válido pelo transdutor da extremidade de carga porque o mesmo se inclinou (Figura 4.2) e saiu do ponto de referência da placa colada no tubo, marcando, portanto, deslizamentos incorretos.

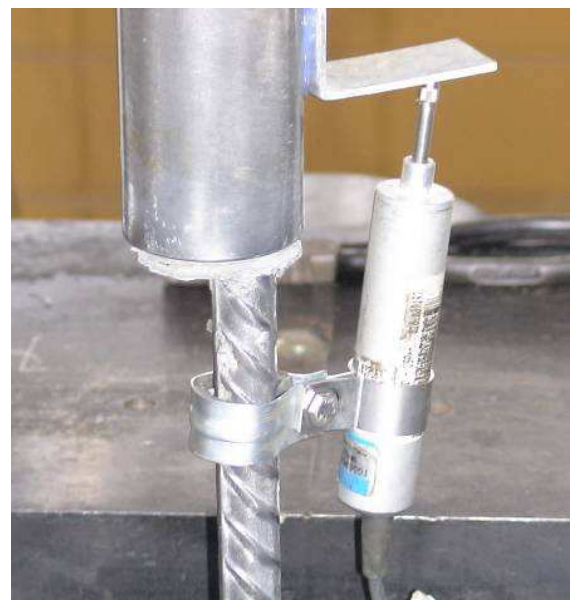

Figura 4.2 - Transdutor inclinado devido a estricção da barra

Percebe-se um trecho descendente de tensão após a força última correspondente à estricção da barra de aço, seguida da sua ruptura brusca (Figura 4.3). Com isso, a capacidade máxima da emenda foi atingida. Houve o aparecimento de algumas fissuras de fendilhamento e destacamento de camada de graute (Figura 4.4) em ambas as extremidades, devido ao cisalhamento, mas que não foi suficiente para ocasionar a ruína da emenda.

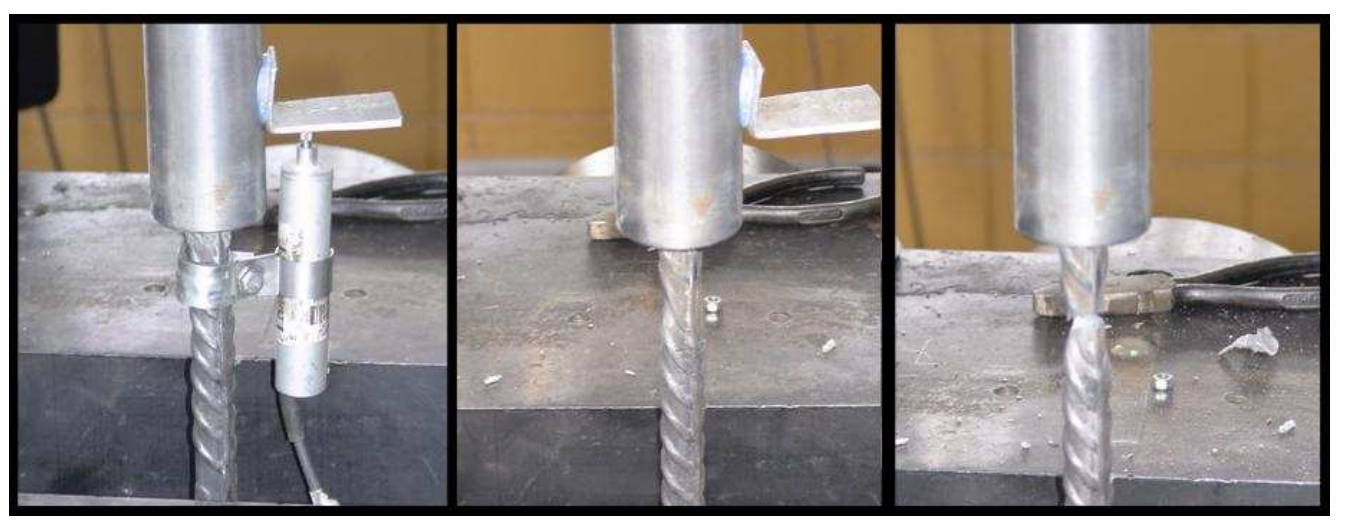

(a)

(b)

(c)

Figura 4.3 - Comportamento da barra a)Início do ensaio, b) Estricção e c) Ruína 


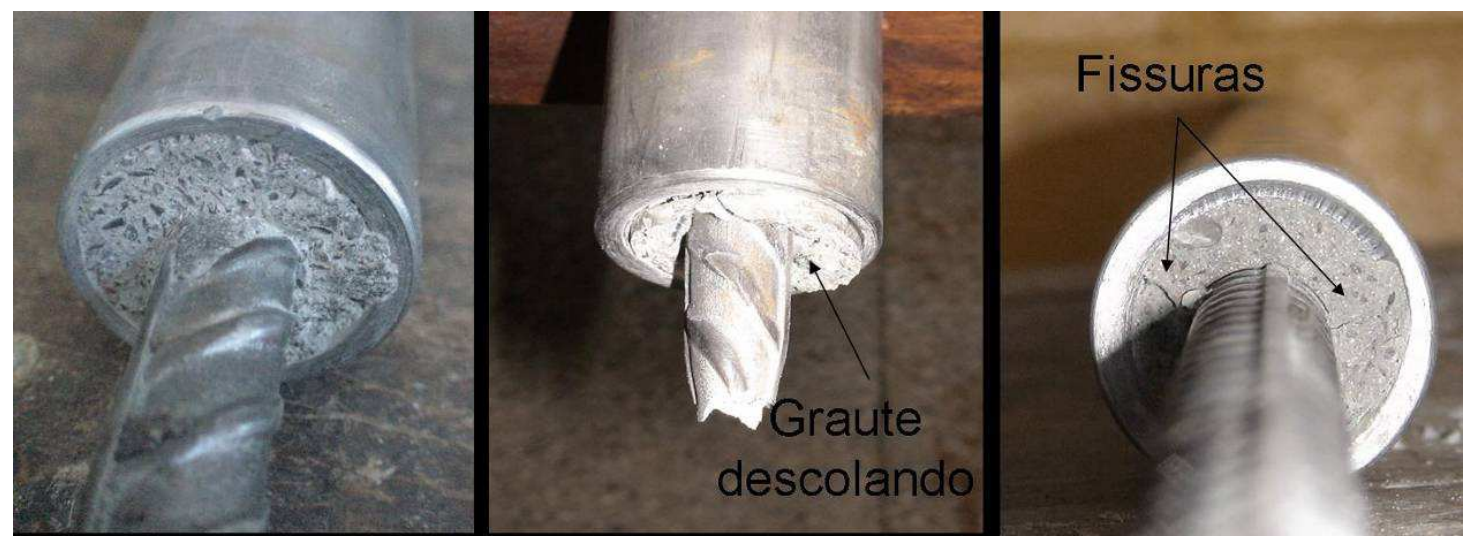

(a)

(b)

(c)

Figura 4.4 - Comportamento do graute a)Antes do ensaio, b) Ruína do Graute e c) Fissuras de fendilhamento

A Figura 4.5 ilustra o comportamento da curva força vs. deslizamento para a emenda TL16-C.

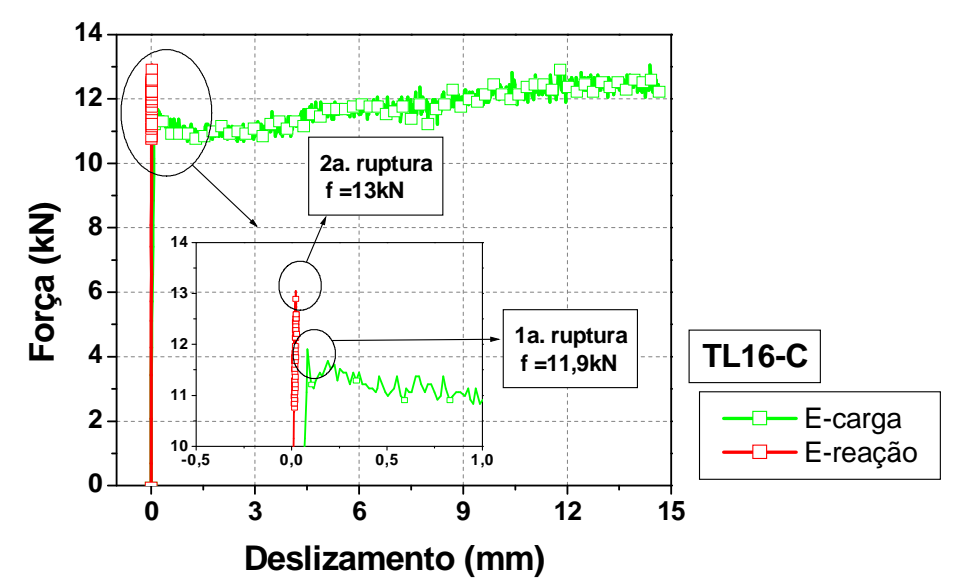

Figura 4.5 - Curva força vs. deslizamento da emenda TL16-C

Conforme a Figura 4.5, houve uma primeira ruptura da emenda na extremidade de carga, devido à perda da adesão entre o graute e o tubo. Após atingir esta força de ruptura, houve um pequeno decréscimo da força devido à perda de rigidez e se iniciou um trecho de atrito mecânico, à força praticamente constante, apenas com um leve aumento. Enquanto isso, a extremidade de reação não deslizou, até atingir a força de ruptura da sua adesão, ocorrendo, portanto, a segunda ruptura da emenda. A partir disso, a força voltou a cair e o ensaio foi terminado. Com isso, considera-se a ruína na extremidade de carga (Figura 4.6). 


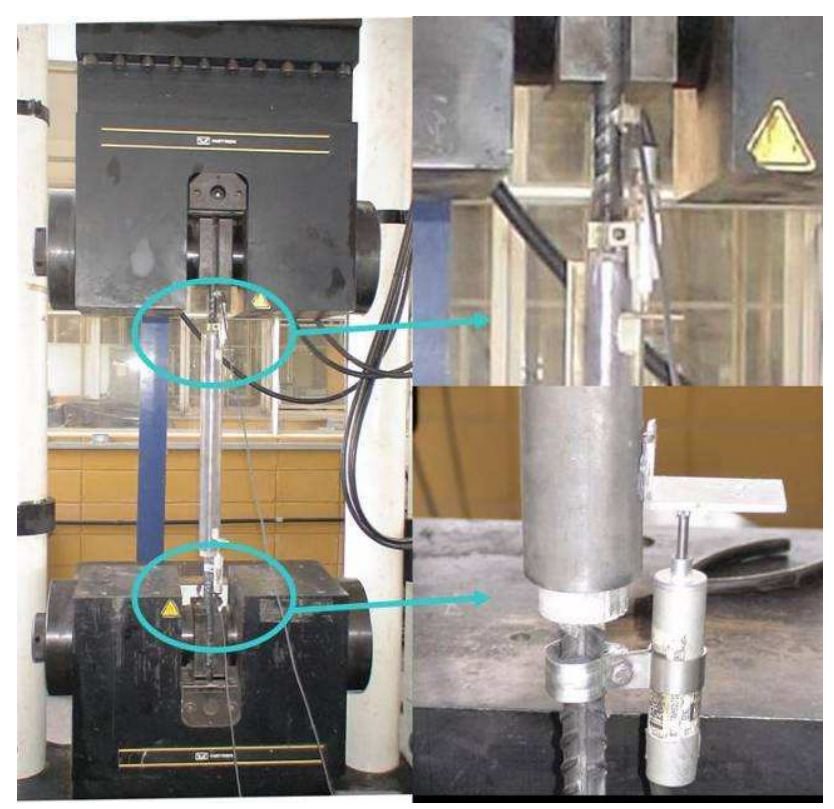

Figura 4.6 - Fim do ensaio, destacando as duas extremidades

A interface superficial entre a seção de graute e o tubo apareceu limpa e lisa, indicando a ocorrência da ruína da ligação pela perda de adesão entre estes elementos e posterior deslizamento por atrito entre as suas superfícies até a sua separação completa.

A Figura 4.7 ilustra o comportamento da curvas força $x$ deslizamento para as emendas TL20-C e TL20-E.
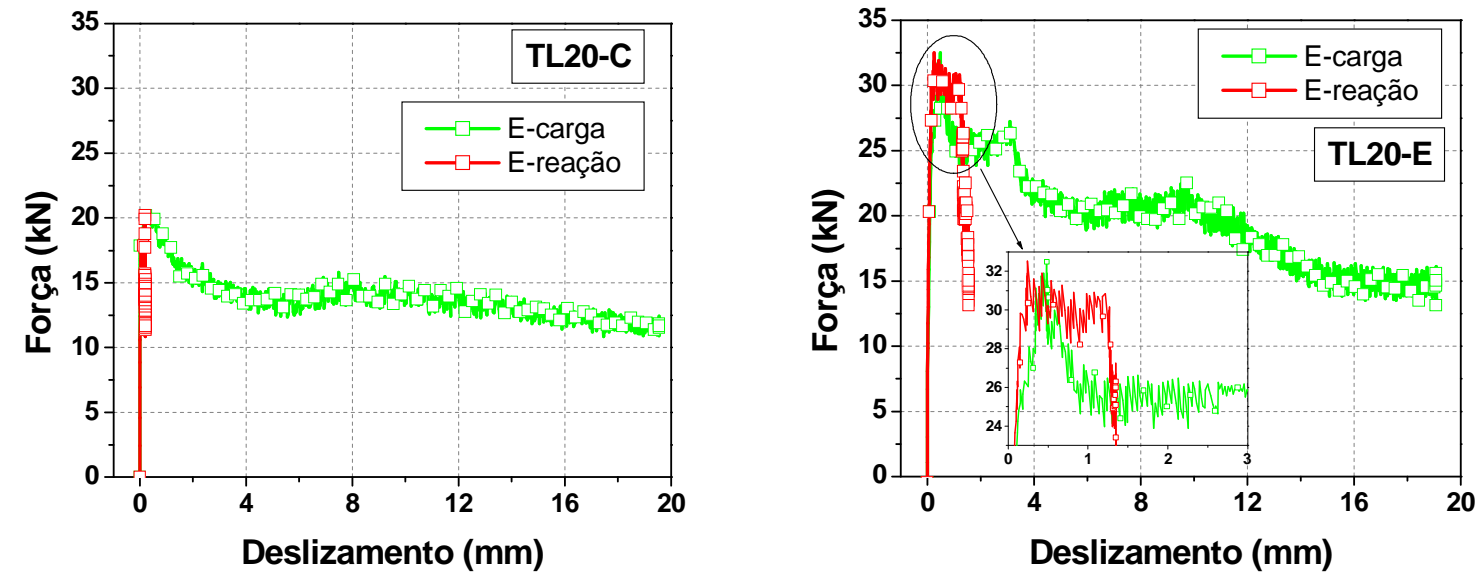

Figura 4.7- Curva força vs. deslizamento das emendas TL20-C e TL20-E

Conforme a Figura 4.7, houve ruína da adesão nas duas extremidades em ambas as emendas à força de 20,4 kN e 32,5 kN, para a emenda TL20-C e TL20-E, respectivamente. Após a ruína se iniciou um trecho de atrito mecânico com diminuição da força na extremidade de carga, enquanto que na extremidade de reação (Figura 4.8) houve redução 
do valor da força aplicada, com deslizamento constante, que ocorreu por causa da perda de rigidez da outra extremidade.

$\mathrm{Na}$ emenda TL20-E, após a ruína se iniciou um trecho de atrito mecânico também em ambas as extremidades, até haver uma queda brusca na força e ficar esse atrito mecânico com diminuição da força apenas na extremidade de carga. $\mathrm{Na}$ extremidade de reação houve redução do valor da força aplicada, com deslizamento constante, que ocorreu por causa da perda de rigidez da outra extremidade.

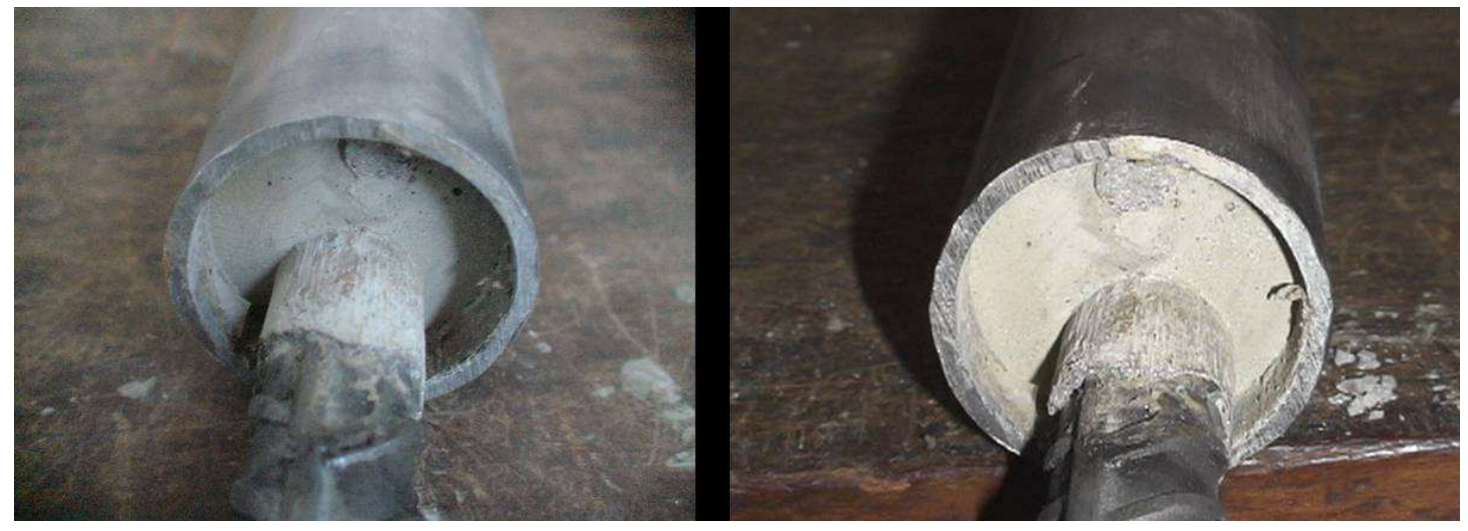

(a)

(b)

Figura 4.8 - Extremidade não solicitada a) antes do ensaio e b) depois do ensaio, inalterada

A interface superficial entre a seção de graute e o tubo apareceu limpa e lisa, indicando a ocorrência da ruína da ligação pela perda de adesão entre estes elementos e posterior deslizamento por atrito entre as suas superfícies até a sua separação completa.

A Figura 4.9 ilustra o comportamento das curvas força vs. deslizamento para as emendas TC25-C e TC25-E.
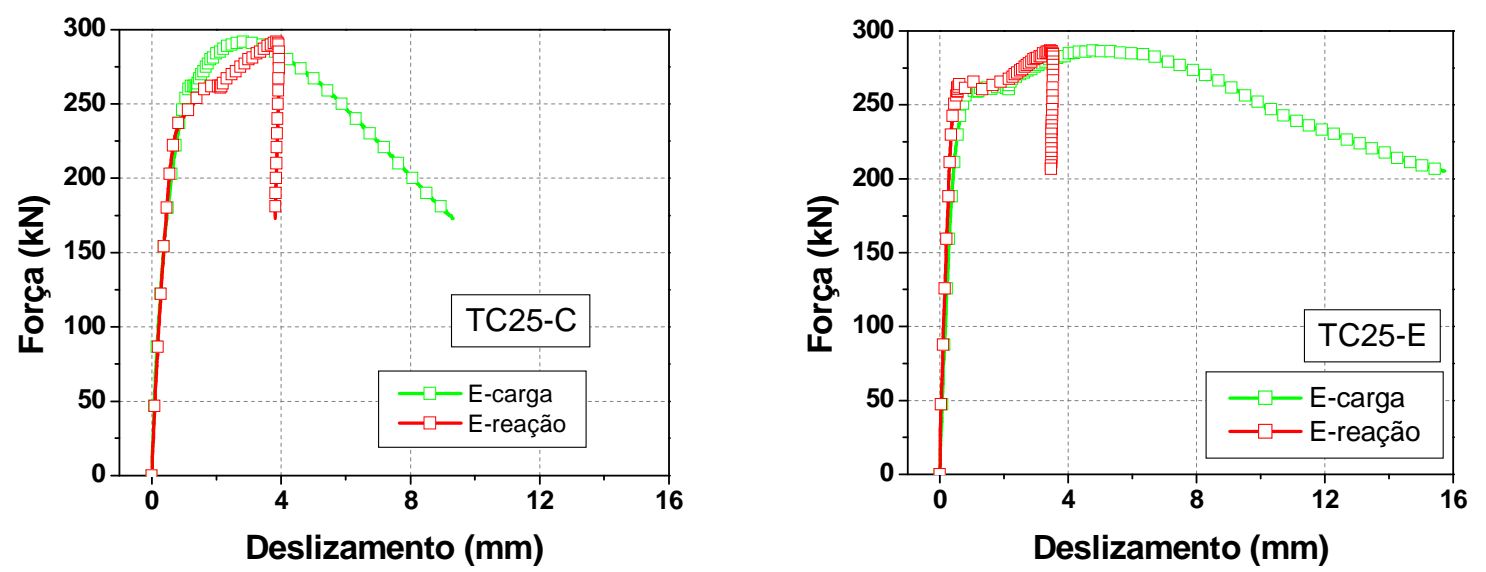

Figura 4.9 - Curva força vs. deslizamento das emendas TC25-C e TC25-E

A partir da Figura 4.9, observa-se um comportamento similar entre as duas emendas. Após a força última ter sido atingida $(292 \mathrm{kN}$ e $287 \mathrm{kN}$, respectivamente para as emendas TC25-C e TC25-E), não foi admitido mais acréscimo de força, significando que foi atingido o limite máximo da capacidade da ligação e constatando a ruína na extremidade de carga por 
deslizamento da barra em relação ao graute (Figura 4.10-c), devido à ruína da aderência entre eles por causa da pulverização das saliências do concreto adjacente às nervuras da barra de aço. Na extremidade de reação, após a ruína, houve redução do valor da força aplicada, que ocorreu por causa da perda de rigidez da outra extremidade, na qual começou um trecho descendente correspondente ao engrenamento mecânico devido ao atrito da barra com o graute.

Houve o aparecimento de algumas fissuras de fendilhamento e destacamento de camada de graute da extremidade de carga, devido ao cisalhamento, que acarretou na perda da aderência entre a barra e o graute. Na outra extremidade só apareceram fissuras de fendilhamento. (Figuras 4.10 e 4.11)

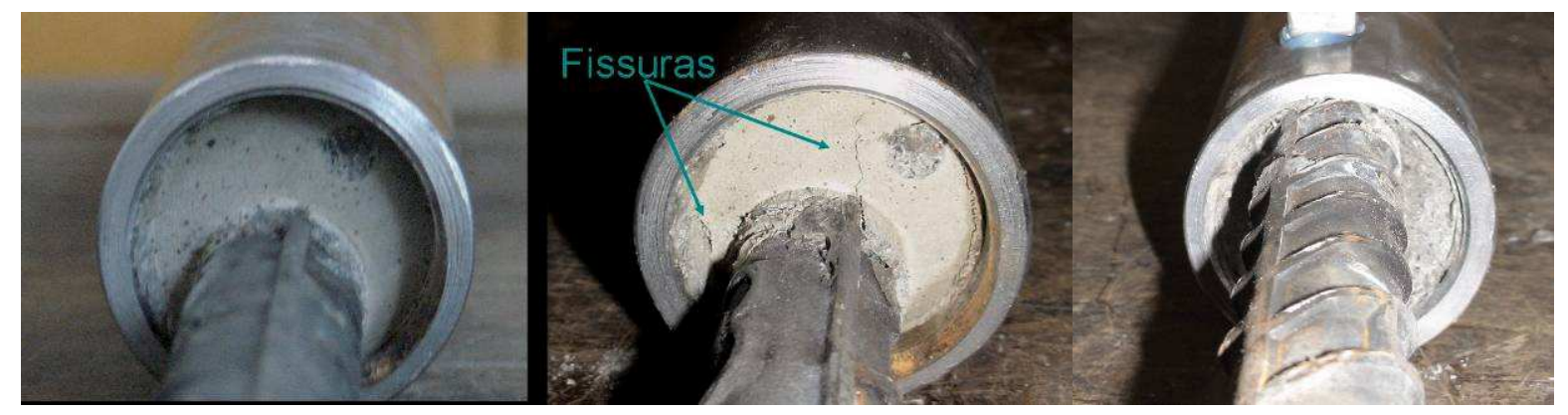

(a)

(b)

(c)

Figura 4.10 - Extremidades a)de reação antes do ensaio e b)depois do ensaio com aparecimento de fissuras de fendilhamento; e c) de carga, com ruína por arrancamento

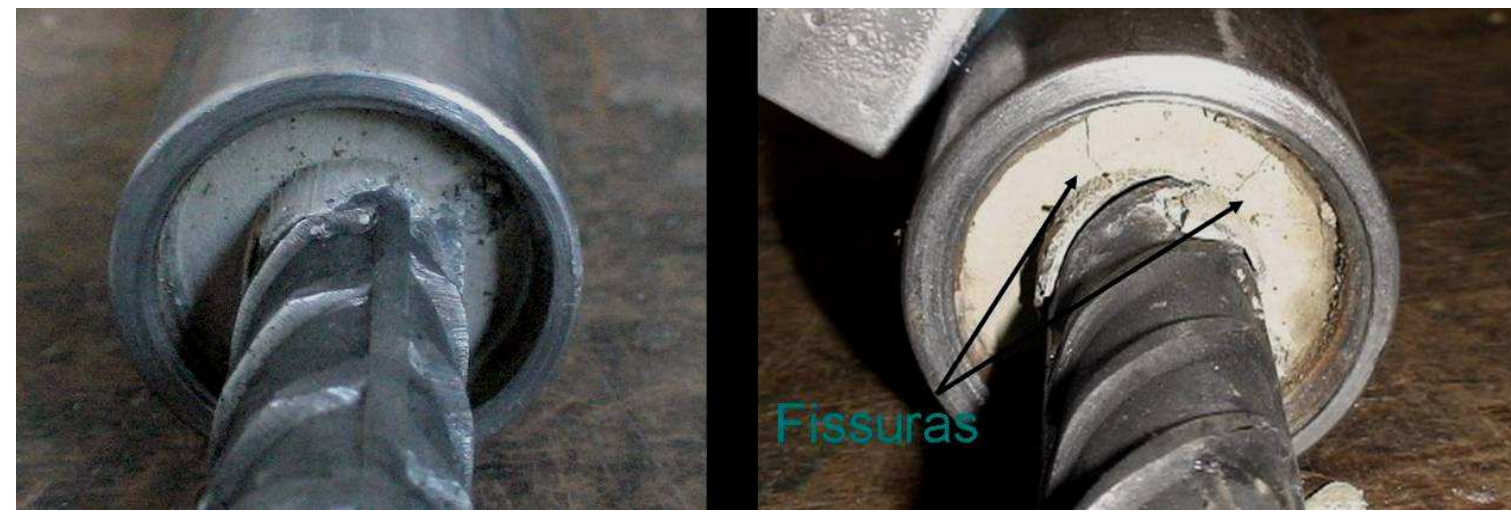

(a)

(b)

Figura 4.11 - Extremidade do transdutor 2 a)antes do ensaio e b)depois do ensaio com aparecimento de fissuras de fendilhamento

A Figura 4.12 ilustra o comportamento da curva força vs. deslizamento para a emenda TL25-C. 


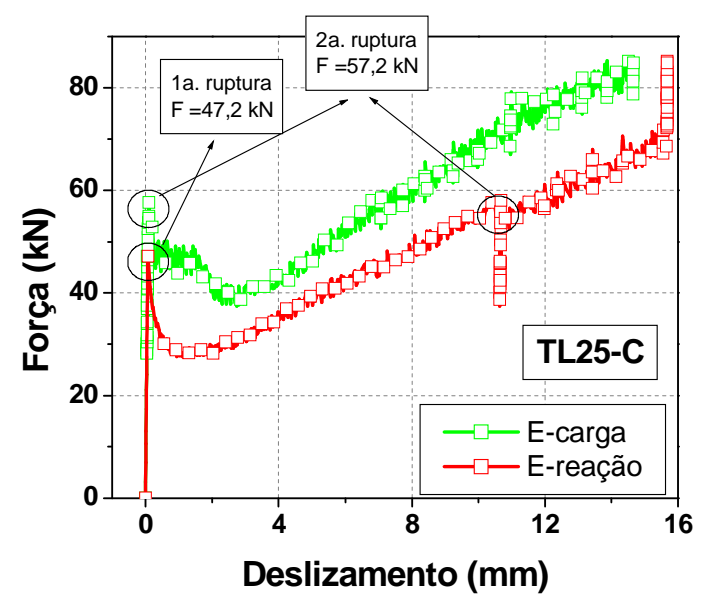

Figura 4.12 - Curva força vs. deslizamento da emenda TL25-C

Conforme a Figura 4.12, houve uma primeira ruptura da emenda na extremidade de reação, devido à perda da adesão. Após atingir esta força de ruptura, houve decréscimo da força devido à perda de rigidez e se iniciou um trecho de atrito mecânico com acréscimo da força. Enquanto isso, a extremidade de reação não deslizou, até atingir a força de ruptura da sua adesão, ocorrendo, portanto, a segunda ruptura da emenda. A partir disso, a força voltou a cair e novamente ocorreu o trecho de atrito mecânico com aumento da força. $O$ ensaio foi terminado devido ao fim do curso do transdutor da extremidade de reação.

Mesmo após a ruína da emenda, adotou-se a continuidade da aplicação da força à amostra, observando a quase saída completa da barra com o graute. Essa saída completa só não foi possível por ter sido atingido o final de curso do cilindro de ensaio. Com isso, observou-se a interface superficial entre a seção de graute e do tubo limpa e lisa, indicando a ocorrência da ruína da ligação pela perda de adesão e posterior deslizamento por atrito entre as suas superfícies até a sua separação completa. (Figura 4.13)

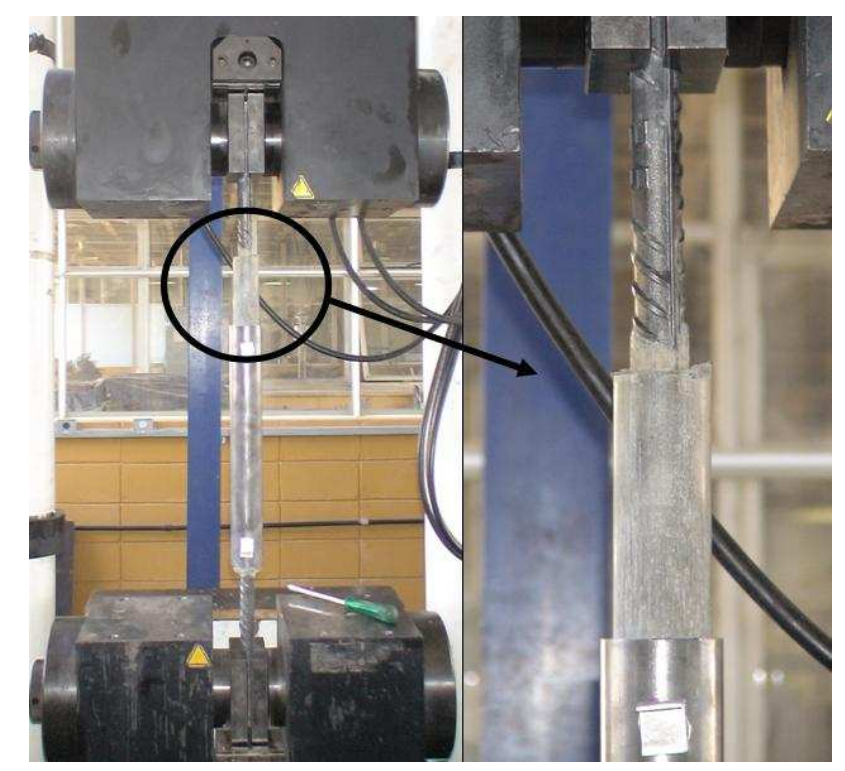

Figura 4.13 - Fim do ensaio, destacando a ruptura entre a interface do graute e do tubo 
A partir destes ensaios foi obtida a capacidade resistente da emenda e seus modos de ruína, para estabelecer o ensaio definitivo.

\subsubsection{Resumo dos resultados}

A Tabela 4.7 apresenta um resumo dos resultados da série piloto.

Tabela 4.7 - Resumo dos resultados das emendas da série piloto

\begin{tabular}{c|c|c|c|c}
\hline EMENDA & $\begin{array}{c}\text { FORÇA } \\
\text { ÚLTIMA (kN) }\end{array}$ & $\begin{array}{c}\text { TENSÃO AXIAL } \\
\text { ÚLTIMA (MPa) }\end{array}$ & $\begin{array}{c}\text { TENSÃO DE } \\
\text { ADERÊNCIA (MPa) }\end{array}$ & TIPO DE RUíNA \\
\hline TC16-C & 145,0 & 721,2 & 14,4 & Barra \\
TC16-E & 146,0 & 726,2 & 14,5 & Barra \\
TL16-C & 13,0 & 64,7 & 1,3 & aderência graute-tubo \\
TL20-C & 20,4 & 64,9 & 1,6 & aderência graute-tubo \\
TL20-E & 32,5 & 103,5 & 2,6 & aderência graute-tubo \\
TC25-C & 292,0 & 594,9 & 18,6 & aderência graute-barra \\
TC25-E & 287,0 & 584,7 & 18,3 & aderência graute-barra \\
TL25-C & 86,0 & 175,2 & 5,5 & aderência graute-tubo \\
\hline
\end{tabular}

\subsubsection{Comparação entre as emendas}

Os resultados serão analisados e comparados conforme a influência de alguns parâmetros em comum, como a conformação superficial do tubo (liso ou rugoso), diâmetro da barra (16, 20 ou $25 \mathrm{~mm}$ ) e posicionamento da barra em relação ao tubo (centralizado ou excêntrico).

\subsubsection{Influência da corrugação do tubo}

Para analisar a influência da corrugação do tubo foram ensaiados tubos com as mesmas dimensões, mas com diferença na conformação superficial: lisa e rugosa.

A Figura 4.14 ilustra o comportamento da curva força vs. deslizamento para as emendas TL16-C e TC16-C e para as emendas TL25-C e TC25-C. Observa-se comportamento distinto entre a emenda com tubo corrugado e com tubo liso. A emenda TC16-C atingiu a capacidade máxima da ligação, rompendo por escoamento da barra de aço, com uma força última 11 vezes maior que a última atingida pela emenda TL16-C. Apesar da emenda TC25-C não ter atingido sua capacidade máxima, rompendo por cisalhamento do graute, atingiu uma força 3 vezes maior que a emenda TL25-C. As emendas lisas atingiram a ruína na aderência entre o graute e o tubo, e com forças muito baixas, indicando apenas aderência por adesão e atrito, enquanto que as emendas com nervuras apresentaram maior resistência, pois apresentaram também aderência mecânica que resistiu mais que as outras duas parcelas da aderência. 

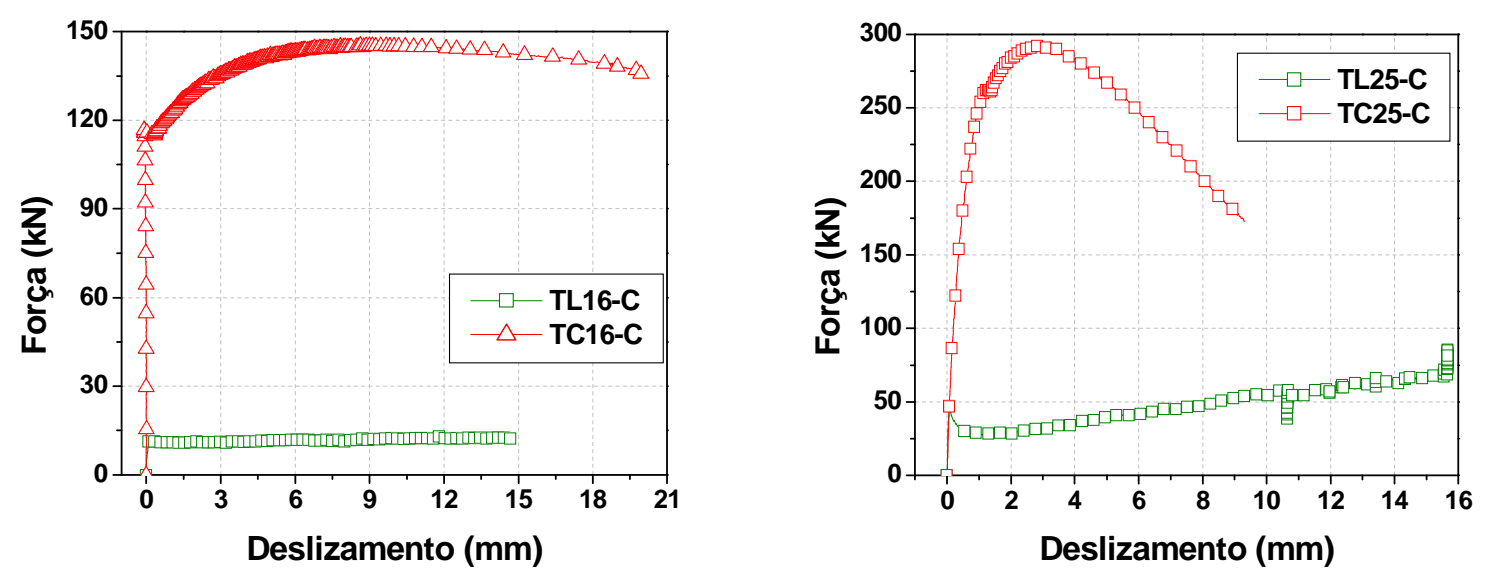

Figura 4.14 - Curva força-deslizamento das emendas TL16-C e TC16-C, TL25-C e TC25-C

Percebe-se a importância da rugosidade nas emendas, visto que as emendas com nervuras apresentaram capacidade de carga bem maior e, consequentemente, melhor desempenho da ligação. A utilização de tubos lisos para este tipo de emenda foi descartada, a não ser para casos com baixa solicitação de carga, onde outros tipos de emenda são tão eficientes quanto. Por isso, as emendas com parede interna do tubo lisa não foram mais consideradas para a série definitiva.

\subsubsection{Influência do diâmetro da barra de aço}

Para analisar a influência do diâmetro da barra foram comparadas emendas com as mesmas características, alterando-se o diâmetro da barra para as emendas com superfície rugosa (16 mm e $25 \mathrm{~mm}$ ) e lisa ( $16 \mathrm{~mm}, 20 \mathrm{~mm}$ e $25 \mathrm{~mm}$ ). Ao se alterar o diâmetro da barra, o diâmetro do tubo também foi alterado, pois eles mantêm uma relação de proporcionalidade e, consequentemente, o cobrimento também foi alterado, de uma emenda para outra.

\subsection{Tubos lisos}

A Figura 4.15 ilustra o comportamento das curvas tensão axial vs. deslizamento e tensão de aderência vs. deslizamento, respectivamente, para as emendas TL25-C, TL20-C e TL16-C. 

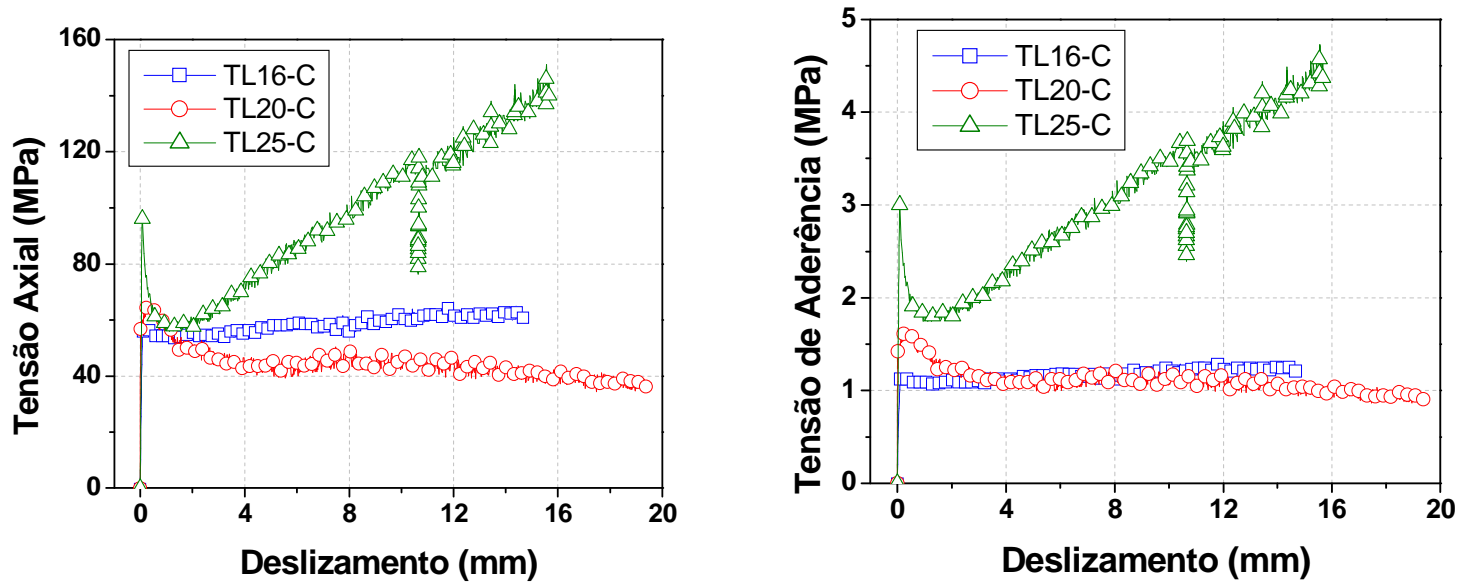

Figura 4.15 - Curva tensão-deslizamento e tensão de aderência-deslizamento das emendas TL25-C, TL20-C e TL16-C

Observa-se na Figura 4.15 que com o aumento do diâmetro, houve aumento na capacidade de carga da emenda, tanto na tensão axial como na tensão de aderência atingida. Todas as emendas apresentaram o mesmo modo de ruína que foi da aderência do graute com o tubo.

\subsection{Tubos corrugados}

As Figuras 4.16 e 4.17 ilustram o comportamento das curvas tensão axial vs. deslizamento e tensão de aderência vs. deslizamento, respectivamente, para as emendas TC25-C e TC16-C e para as emendas TC25-E e TC16-E, respectivamente.
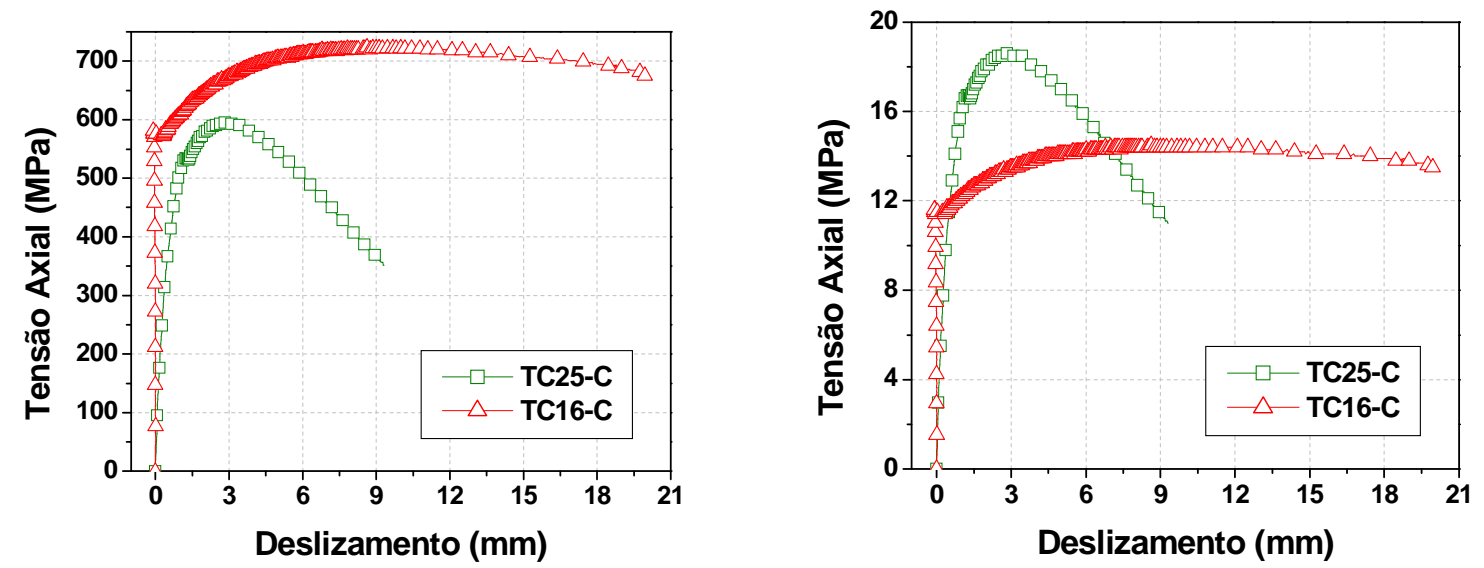

Figura 4.16 - Curva tensão-deslizamento e tensão de aderência-deslizamento das emendas TC25-C e TC16-C 

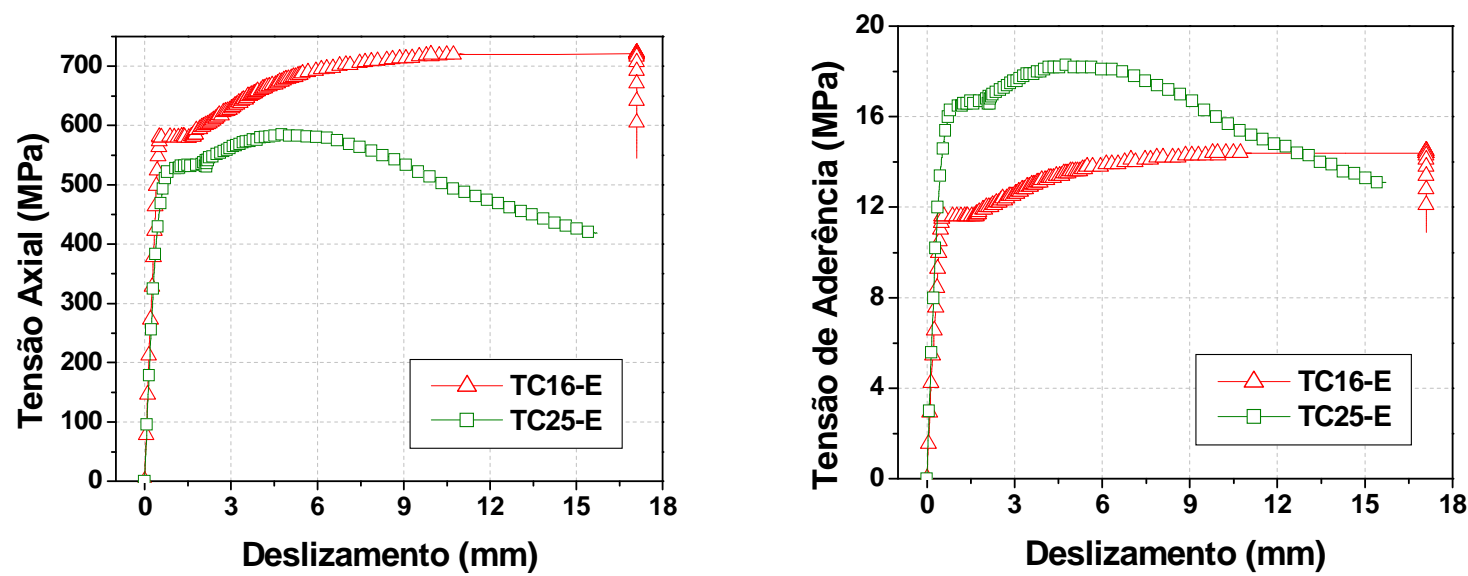

Figura 4.17 - Curva tensão-deslizamento e tensão de aderência-deslizamento das emendas TC25-E e TC16-E

Observa-se na Figura 4.16 e 4.17 que com o aumento do diâmetro, houve aumento na tensão axial atingida e diminuição da tensão de aderência.

Sabe-se que quanto maior o diâmetro da barra, menor a tensão de aderência, o que não foi observado aqui. Isso ocorreu devido aos modos de ruína atingidos terem sido diferentes. As emendas com barra de $16 \mathrm{~mm}$ atingiram a ruína por escoamento da barra de aço, e, provavelmente que não atingiram a capacidade última de resistência de aderência, sendo, neste caso, difícil de determinar sua resistência última de tensão de aderência, que provavelmente seria um valor maior, enquanto que as emendas com barra de $25 \mathrm{~mm}$, atingiram sua capacidade máxima de resistência de aderência, visto que sua ruína foi devido a ela. Isto pode ser constatado também porque a tensão axial diminuiu com o aumento do diâmetro do tubo.

\subsubsection{Influência do posicionamento das barras}

A Figura 4.18 ilustra o comportamento das curvas força vs. deslizamento, para as emendas TC16-C e TC16-E, TL20-C e TL20-E, e para as emendas TC25-C e TC25-E, respectivamente. Observa-se um comportamento similar entre as emendas independente do posicionamento da barra, com mesmo modo de ruína e atingindo a mesma força última, exceto entre as emendas TL20-C e TL20-E onde a emenda excêntrica obteve uma força última 1,5 vez maior que a emenda com barra centralizada. 

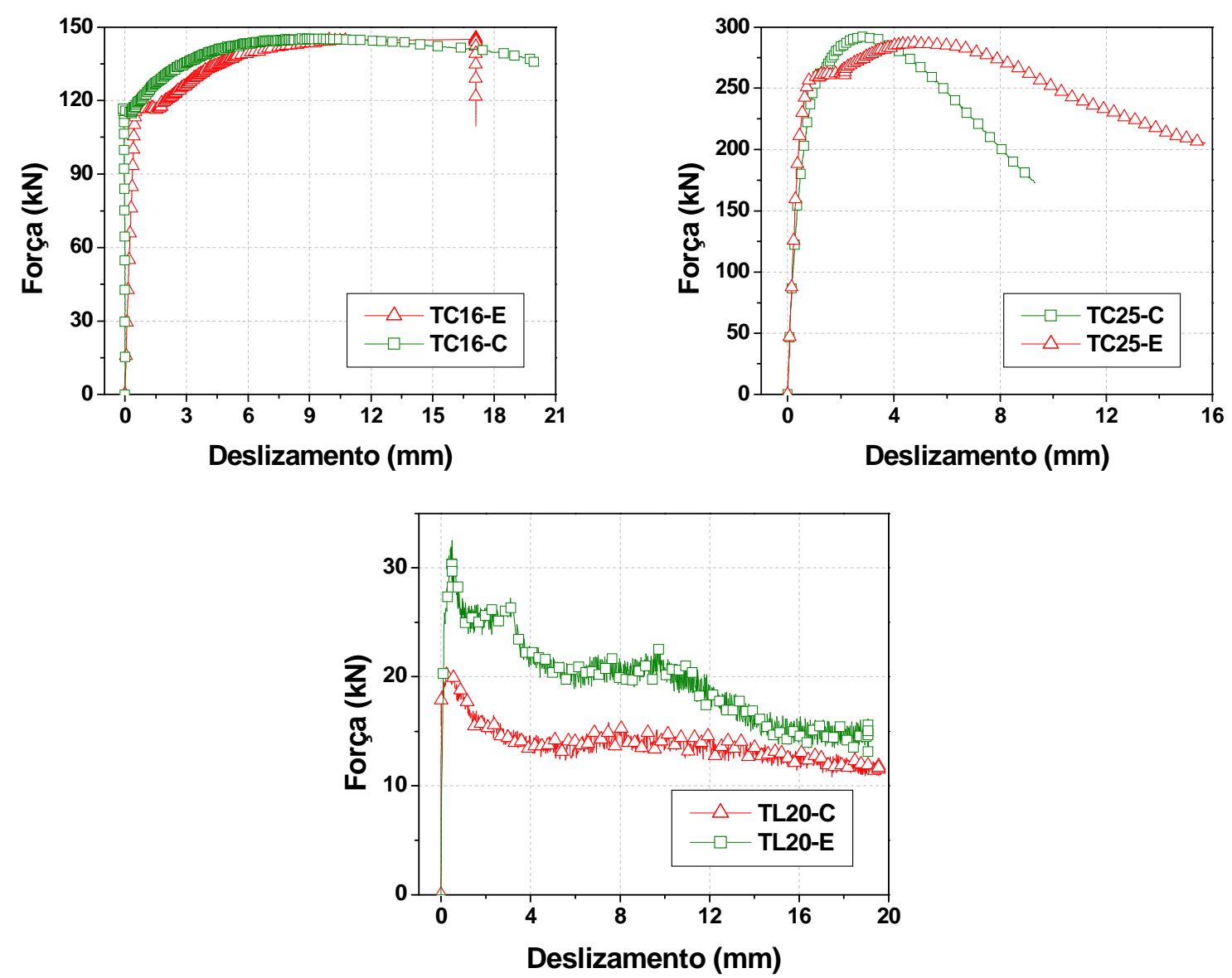

Figura 4.18 - Curva força-deslizamento das emendas TC16-C e TC16-E, TC25-C e TC25-E, e TL20-C e TL20-E

Percebe-se a irrelevância do posicionamento da barra para as emendas corrugadas, visto que obtiveram o mesmo comportamento e capacidade de carga, despreocupando com relação às falhas de execução relacionadas a este posicionamento. Já no caso das emendas com tubo liso, observou-se melhor desempenho com a barra excêntrica, sendo necessário mais estudos para verificar a efetividade desta emenda, que não será feito neste trabalho pois as emendas com tubos lisos foram descartadas para este tipo de ligação, como dito no item 4.3.2.2.1.

\subsection{Série Definitiva}

Estão apresentados os resultados da série definitiva e sua análise, verificando e ratificando a relevância de cada parâmetro estudado.

\subsubsection{Resultados das emendas da Série 1}

A Figura 4.19 mostra as emendas desta série sendo ensaiadas. 


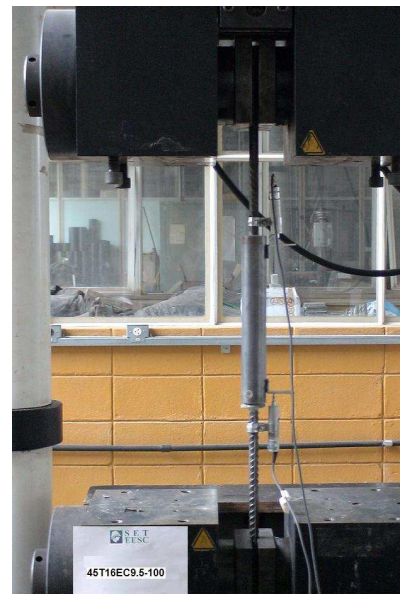

(a)

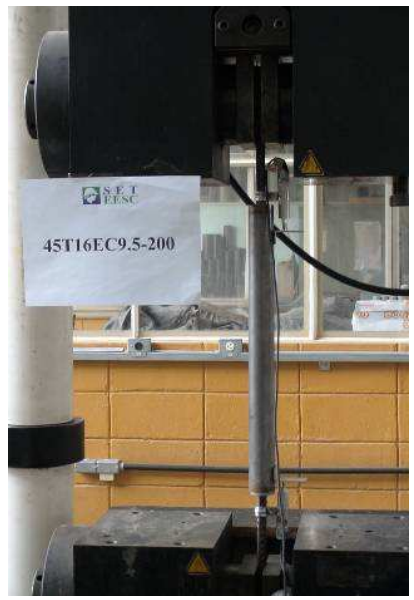

(b)

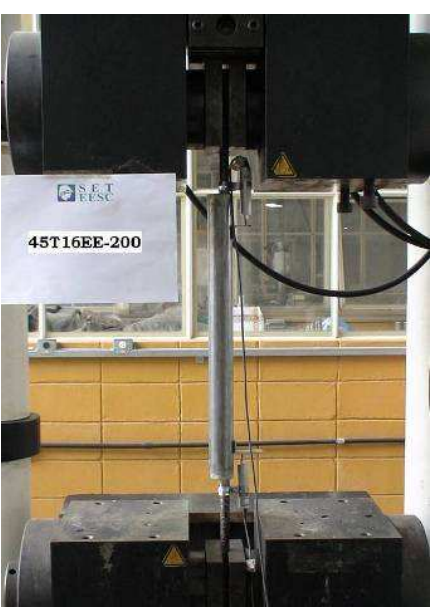

(c)

Figura 4.19 - Emendas sendo ensaiadas a) 45T16EC9.5-100, b) 45T16EC9.5-200 e c) 45T16EE-200

A Figura 4.20 ilustra o comportamento das curvas força vs. deslizamento para os amostras 45T16EC9.5-100A, 45T16EC9.5-100B, 45T16EC9.5-100C e da média deles.
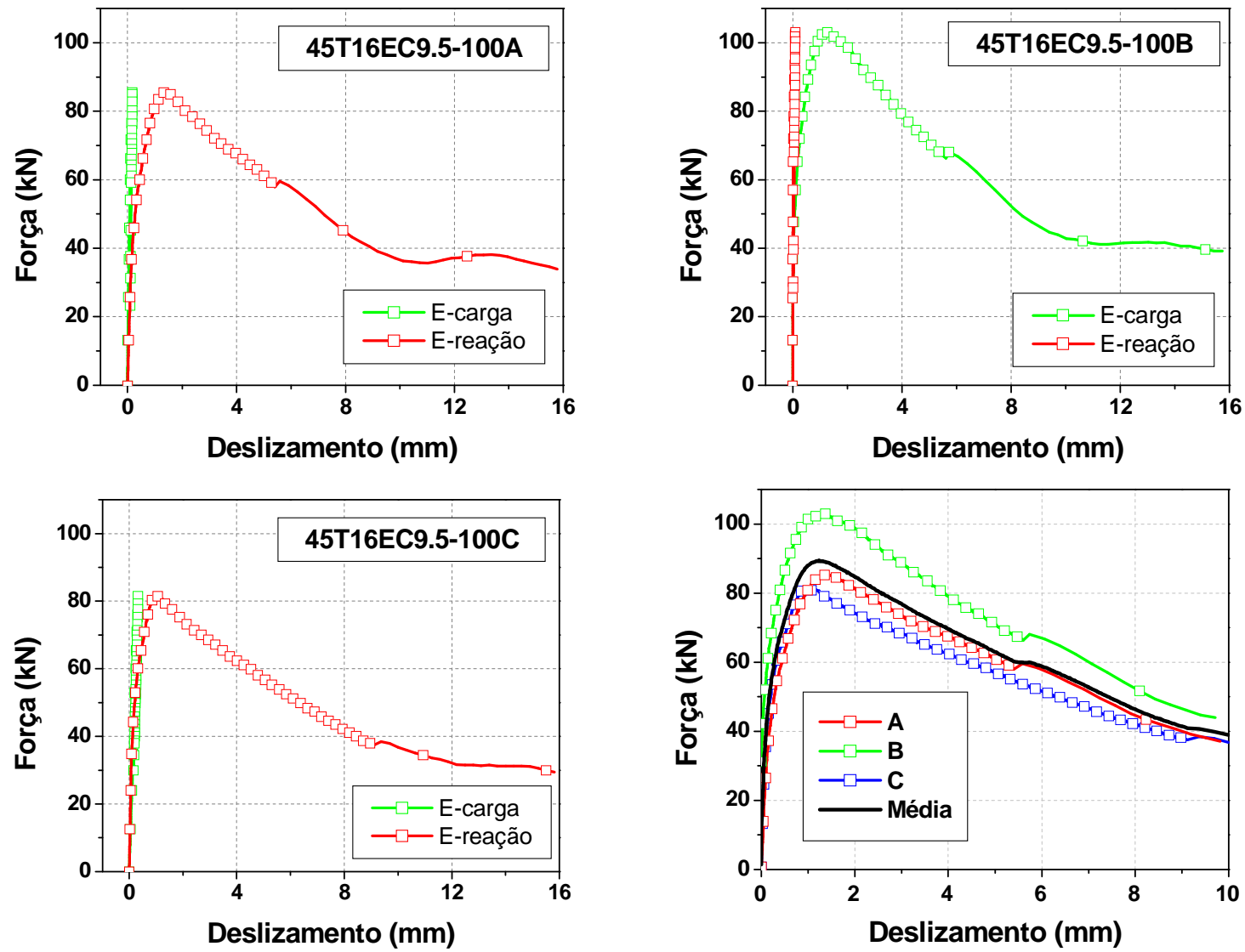

Figura 4.20 - Curva força vs. deslizamento das amostras 45T16EC9.5-100A, 45T16EC9.5-100B, 45T16EC9.5-100C e da média delas 
Na Figura 4.20 observa-se um comportamento similar entre as três amostras. Após a força última ter sido atingida $(85,5 \mathrm{kN}, 103 \mathrm{kN}$ e $81,6 \mathrm{kN}$, respectivamente para as amostras 45T16EC9.5-100A, 45T16EC9.5-100B e 45T16EC9.5-100C), não foi admitido mais acréscimo de força, significando que foi atingido o limite máximo da capacidade da ligação e constatando a ruína, que, para todos as amostras da série 45T16EC9.5-100, ocorreu por deslizamento da barra em relação ao graute, devido à ruína da aderência entre eles (Figuras 4.21-c e 4.21-d). Apenas para a emenda 45T16EC9.5-100B, a ruína ocorreu na extremidade de carga. A extremidade que não rompeu, também não deslizou (Figura 4.22). Após a ruína houve redução do valor da força aplicada e começou um trecho descendente correspondente engrenamento mecânico devido ao atrito da barra com o graute.

Durante o ensaio houve o aparecimento de algumas fissuras de fendilhamento e destacamento de camada de graute (Figura 4.21-a e 4.21-b) apenas na extremidade rompida, devido ao cisalhamento, mas que não foram suficientes para ocasionar a ruína da emenda.

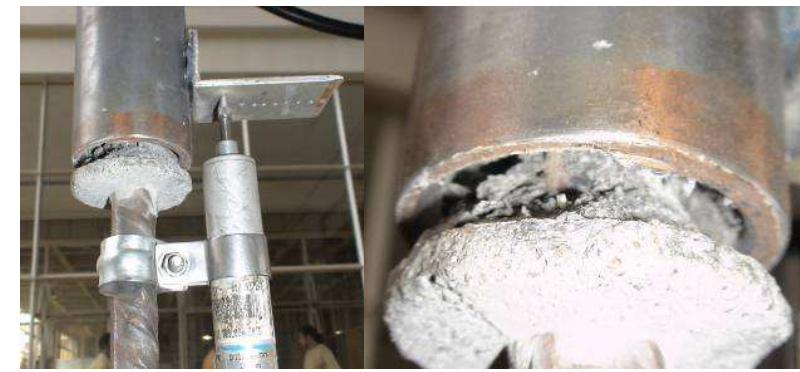

(a) (b)

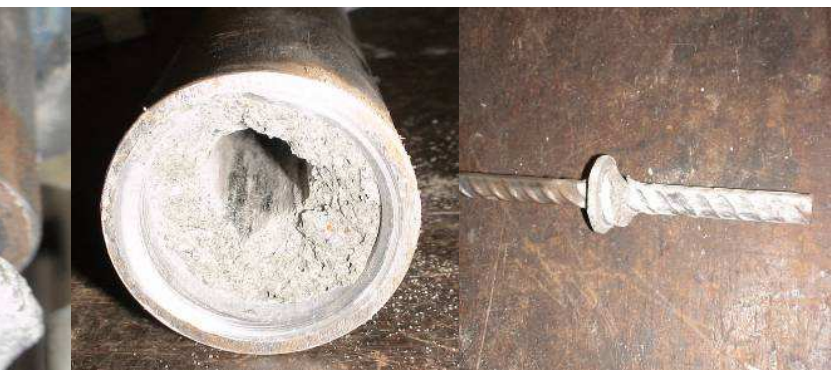

(c) (d)

Figura 4.21 - Extremidade que apresentou ruína: a) e b) Durante o ensaio, graute rompido; c) e d) Fim do ensaio, barra arrancada do graute

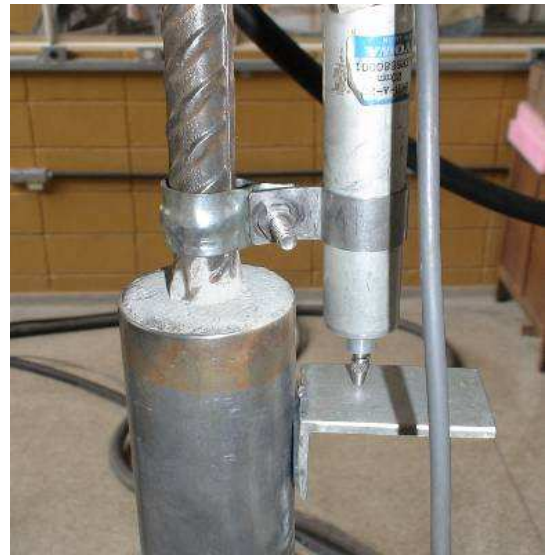

(a)

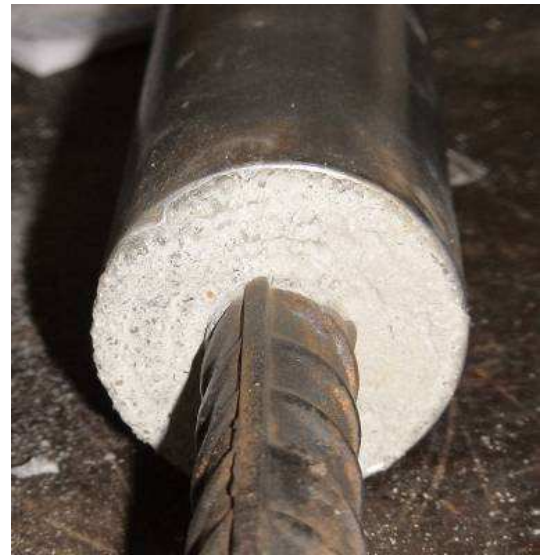

(b)

Figura 4.22 - Extremidade íntegra: a) Durante o ensaio e b) Fim do ensaio, inalterada

Como o comportamento das três amostras foi similar, a curva representativa da emenda 45T16EC9.C-100 será a média deles, ilustrada na Figura 4.20. 
Entre as amostras da série 45T16EC9.5-200, a emenda 45T16EC9.5-200A foi instrumentada com extensômetros ao longo do tubo e da barra, além dos dois transdutores de deslocamento (Figura 4.23).

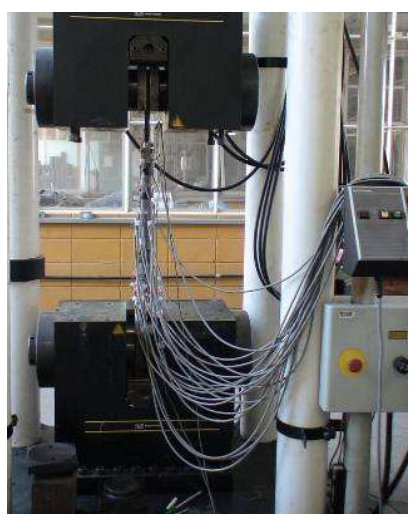

(a)

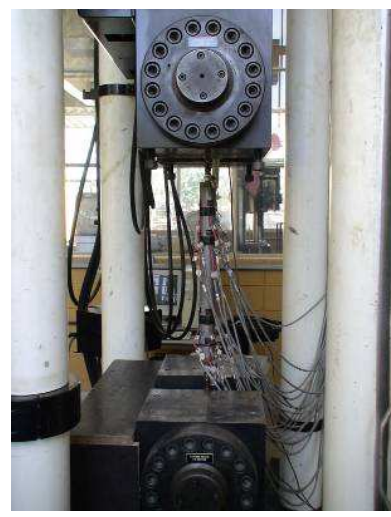

(b)

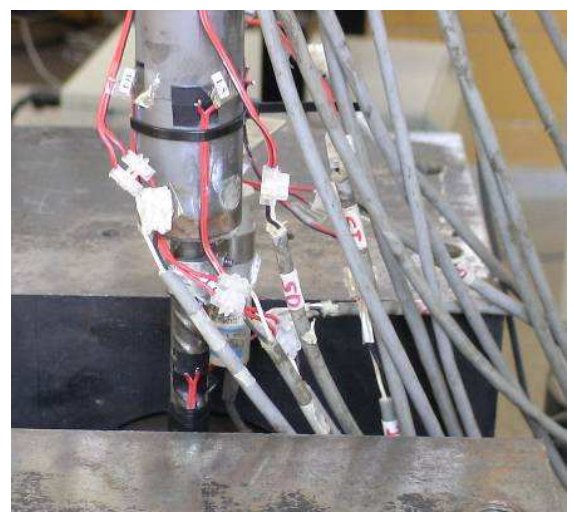

(c)

Figura 4.23 - Amostra 45T16EC9.5-200A instrumentada a) vista frontal, b) vista lateral e c) detalhe da extremidade de reação

A Figura 4.24 ilustra o comportamento das curvas tensão vs. deformação dos extensômetros colados na barra da amostra 45T16EC9.5-200A.
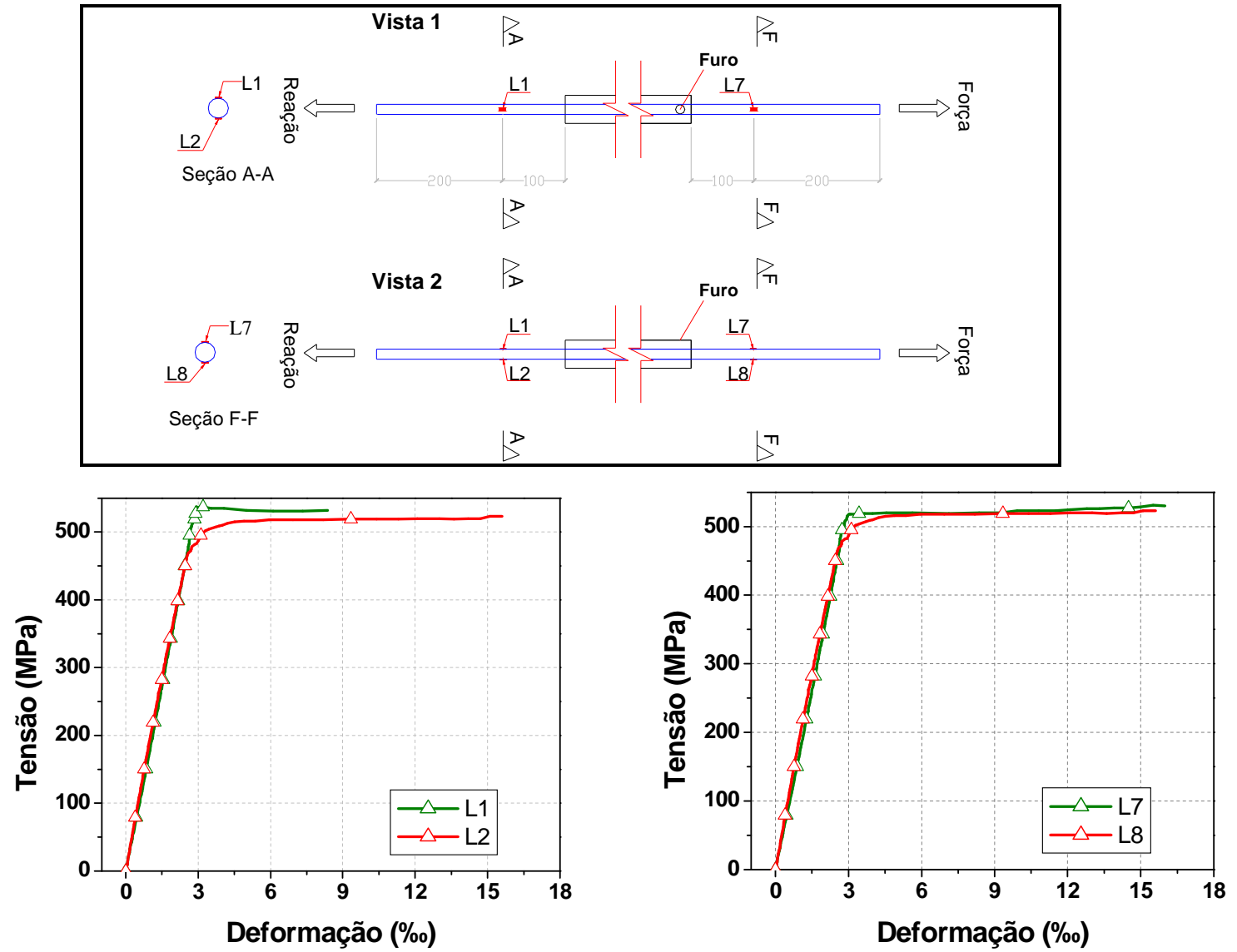

Figura 4.24 - Curva tensão-deformação dos resultados dos extensômetros longitudinais da barra da amostra 45T16EC9.5-200A da a)extremidade de reação e b)extremidade de carga 
Observa-se na Figura 4.24 um comportamento similar entre os resultados dos extensômetros de ambas as extremidades, típico do aço CA-50. Os extensômetros da extremidade de carga, onde houve a ruína da emenda, atingiram os seus limites de escoamento e não registraram mais deslizamentos. À força de 108 kN ( 531 MPa de tensão) houve a máxima deformação registrada pela extremidade de reação, por um provável descolamento dos extensômetros, fornecendo valores inválidos.

A Figura 4.25 ilustra o comportamento das curvas tensão vs. deformação dos extensômetros colados longitudinalmente no tubo da amostra 45T16EC9.5-200A.
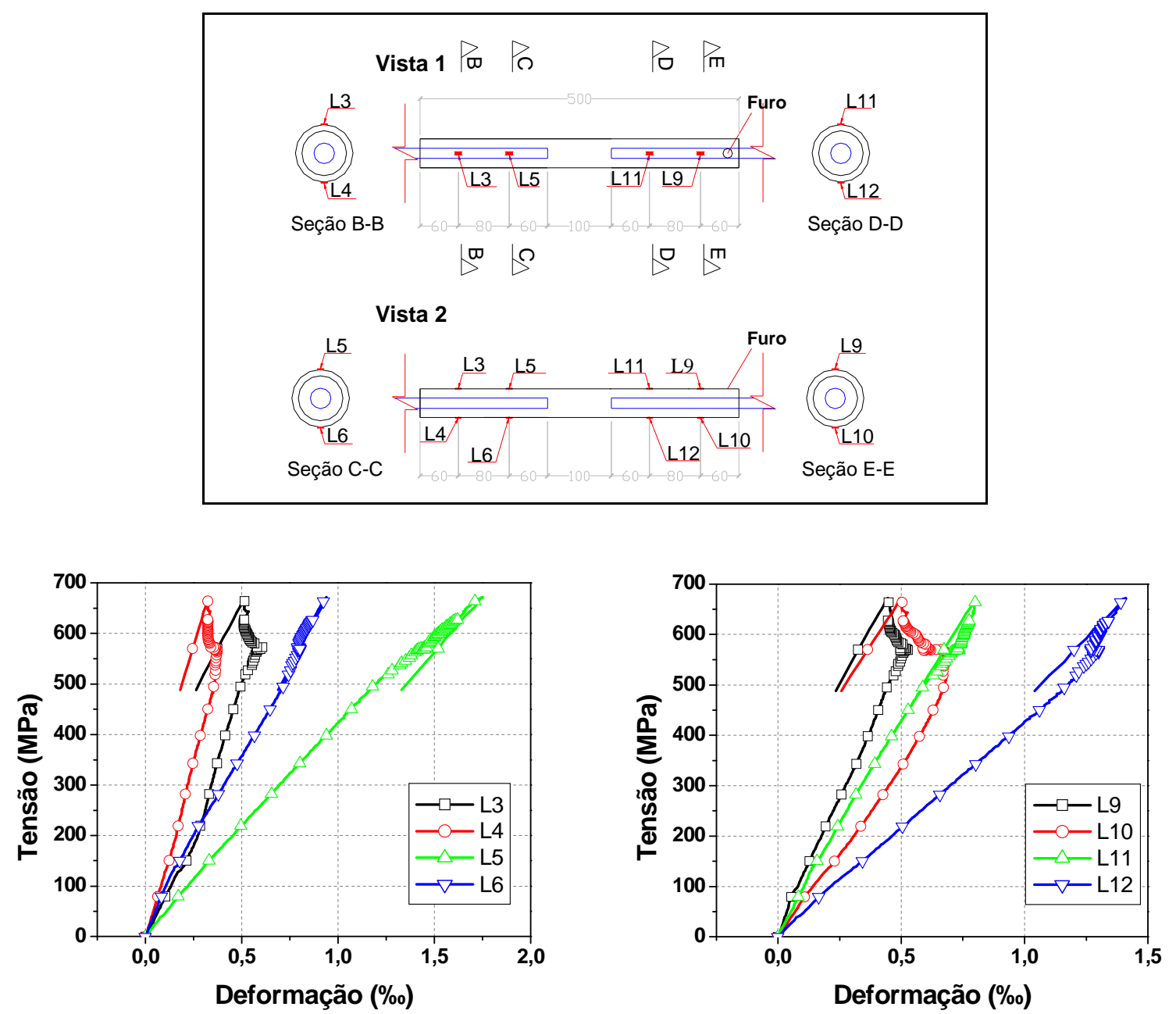

Figura 4.25 - Curva tensão-deformação dos resultados dos extensômetros longitudinais da amostra 45T16EC9.5-200A da a)extremidade de reação e b)extremidade de carga

Na Figura 4.25 observa-se um comportamento similar em ambas as extremidades, aumentando linearmente a deformação, tracionando o tubo, com o aumento da tensão. A deformação máxima foi atingida na tensão última nos extensômetros próximos ao centro do tubo (L5, L6, L11 E L12). Diferente da deformação máxima nos extensômetros extremos que foi atingida na tensão de $570 \mathrm{MPa}$. A partir da tensão última, há diminuição brusca da 
deformação com a tensão, aparecendo compressão, até ocorrer a ruína da barra. Os extensômetros centrais mostraram maiores deformações no tubo do que os localizados na extremidade do tubo.

A Figura 4.26 ilustra o comportamento das curvas tensão vs. deformação dos resultados dos extensômetros colados na circunferência ao longo do tubo da amostra 45T16EC9.C-200A.
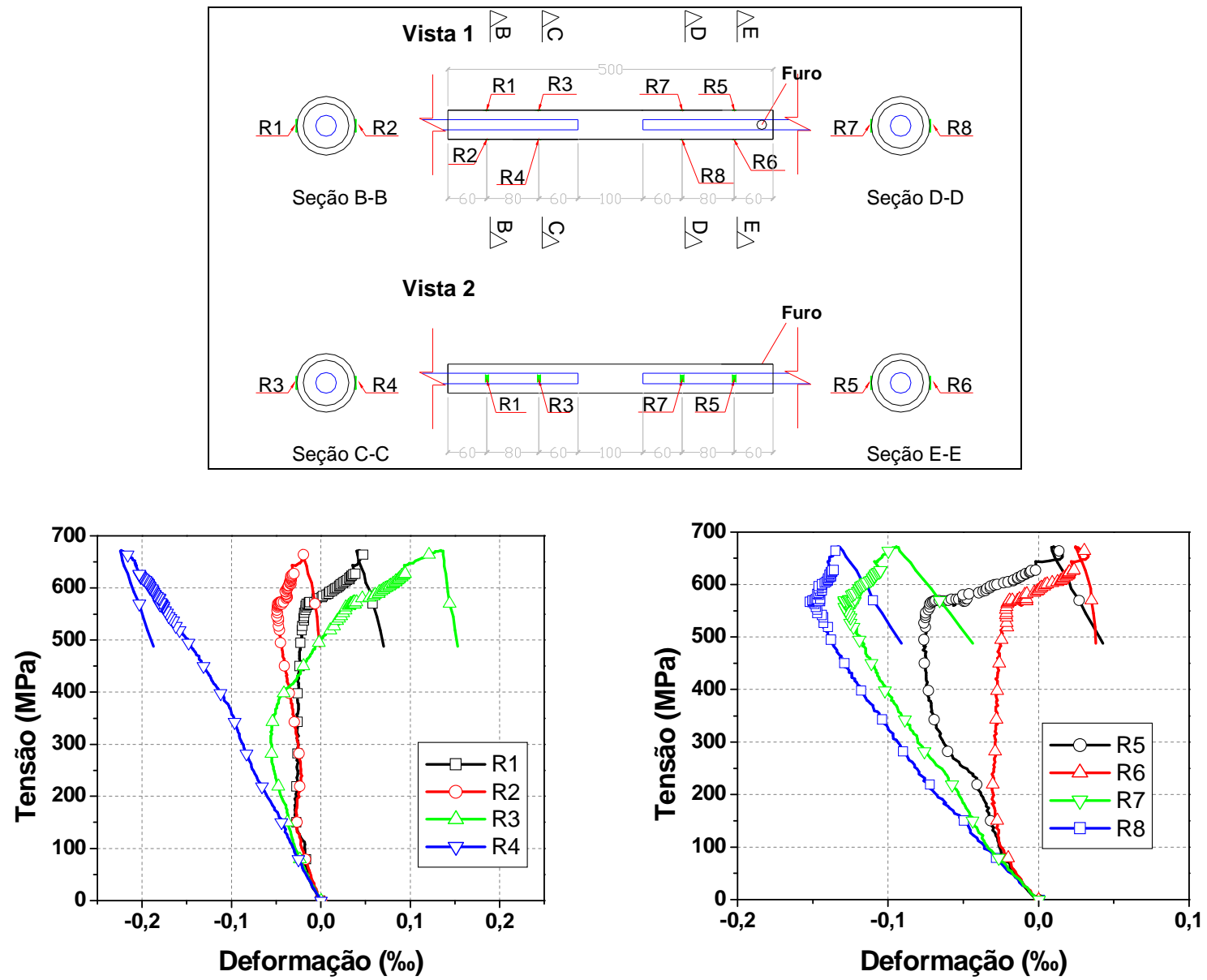

Figura 4.26 - Curva tensão-deformação dos resultados dos extensômetros circunferenciais da amostra 45T16EC9.5-200A da a)extremidade de reação e b)extremidade de carga

Entre as duas extremidades, os resultados foram diferentes. Sendo que na extremidade de reação, os extensômetros extremos obtiveram comportamento similar e os centrais apresentaram comportamento contrário. Já na extremidade de carregamento, os extensômetros apresentaram comportamento similar, sendo que os extensômetros centrais mostraram deformações maiores do tubo, representando compressão maior no centro do tubo. Com exceção dos extensômetros R3 e R4, todos os extensômetros inicialmente mostraram compressão do tubos e a partir de $570 \mathrm{MPa}$ inverteram o sentido dos esforços, mostrando tração. 
A Figura 4.27 ilustra o comportamento das curvas força vs. deslizamento para as amostras 45T16EC9.5-200A e 45T16EC9.5-200B, com deslizamentos medidos pelos transdutores.
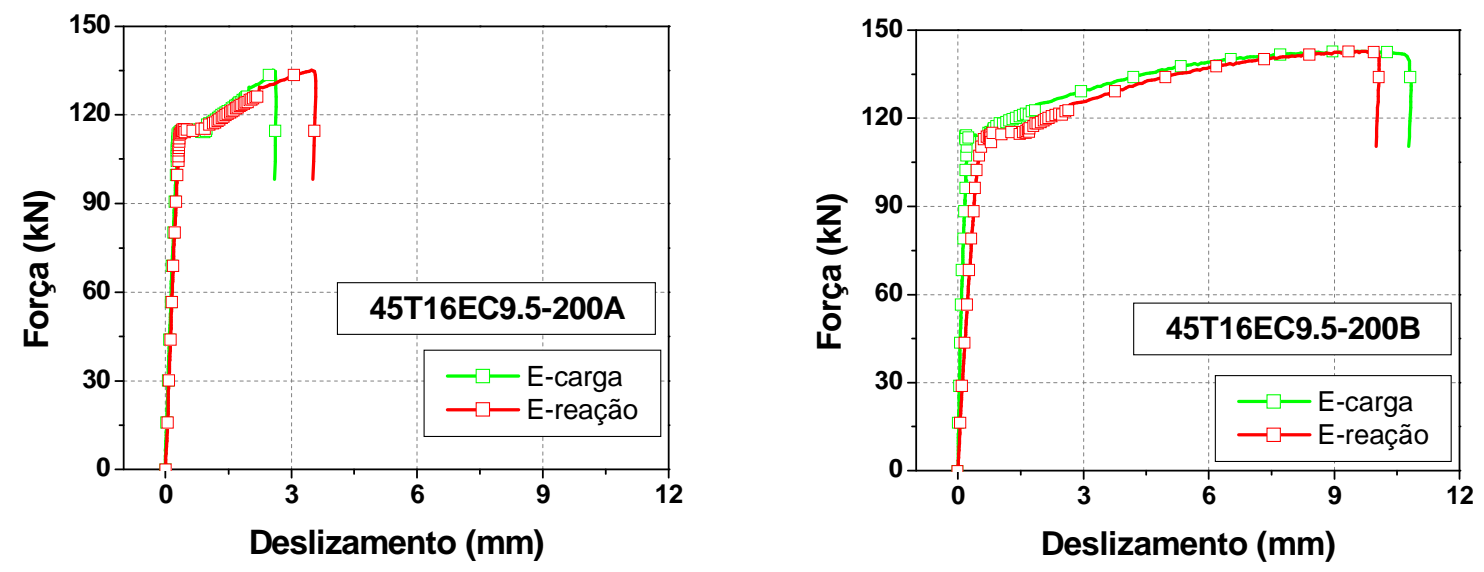

Figura 4.27 - Curva força vs. deslizamento das amostras 45T16EC9.5-200A e 45T16EC9.5-200B

A partir da Figura 4.27, observa-se que após a força última ter sido atingida (135 kN e $143 \mathrm{kN}$, respectivamente para as amostras 45T16EC9.5-200A e 45T16EC9.5-200B), não foi admitido mais acréscimo de força, significando que foi atingido o limite máximo da capacidade da ligação e constatando a ruína na extremidade de carga. Após a força última, ter sido atingida houve redução do valor da força aplicada, com deslizamento constante. No caso da extremidade de carga isso foi devido à perda de rigidez da outra extremidade que se rompeu. $E$ na extremidade rompida, foi devido à estricção e consequente ruptura da barra de aço ter ocorrido num posicionamento fora da área abrangente pelo ponto de medição do transdutor de deslocamento.

A ruína observada foi por escoamento da barra de aço, atingindo, portanto, a capacidade máxima da emenda. Houve o aparecimento de algumas fissuras de fendilhamento e destacamento de camada de graute em ambas as extremidades, devido ao cisalhamento, mas que não foram suficientes para ocasionar a ruína da emenda.

$\mathrm{Na}$ emenda instrumentada (45T16EC9.5-200A) a estricção e consequente ruína da barra de aço ocorreu exatamente no ponto onde o extensômetro estava colado (Figura 4.28). Como a seção transversal da barra de aço neste ponto estava menor que as demais, devido à necessidade de lixá-la tornando-a lisa para colar o extensômetro de maneira adequada e com isso obter melhor captação dos dados pelo extensômetro, a ruína ocorreu consequentemente nesta seção. 


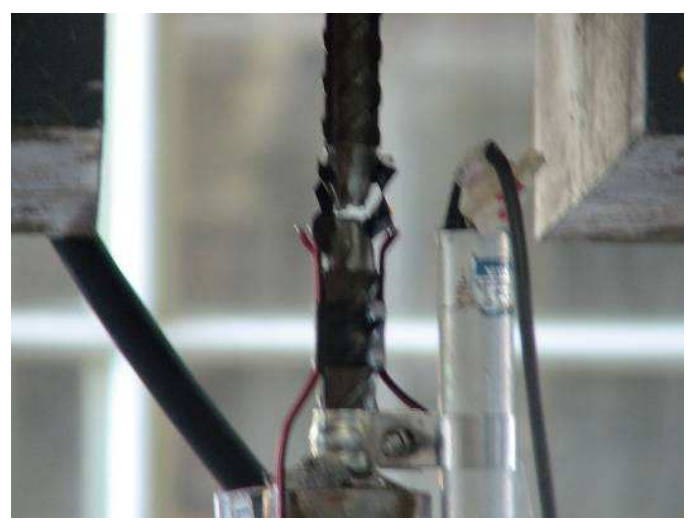

Figura 4.28 - Ruína da barra no extensômetro da extremidade de carga

A Figura 4.29 ilustra o comportamento da curva força vs. deslizamento para a emenda 45T16EC9.5-200C. Observa-se um comportamento diferente desta amostra com as duas anteriores, onde após a força última de $85,2 \mathrm{kN}$ ter sido atingida, não ocorreu acréscimo de força, significando que foi atingido o limite máximo da capacidade da ligação e constatada a ruína na extremidade de reação por deslizamento da barra em relação ao graute, em virtude da ruína da aderência entre eles (Figura 4.30). A extremidade que não rompeu, também não deslizou e apresentou uma superfície inalterada (Figura 4.31). Após a ruína houve redução do valor da força aplicada e começou um trecho descendente correspondente ao engrenamento mecânico em virtude do atrito entre a barra e o graute. Apareceram fissuras de fendilhamento e cisalhamento de graute na extremidade rompida.

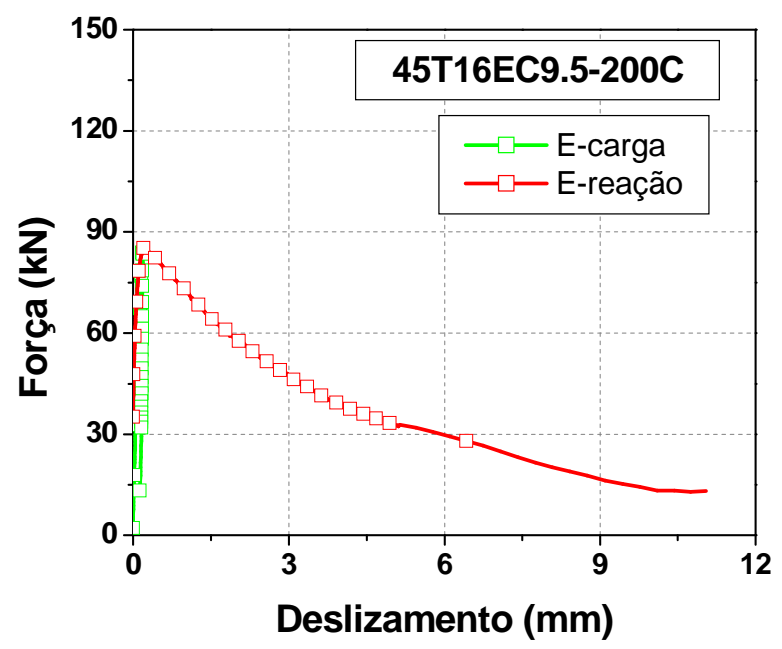

Figura 4.29 - Curva força vs. deslizamento da emenda 45T16EC9.5-200C 


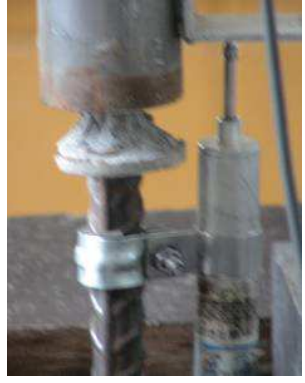

(a)

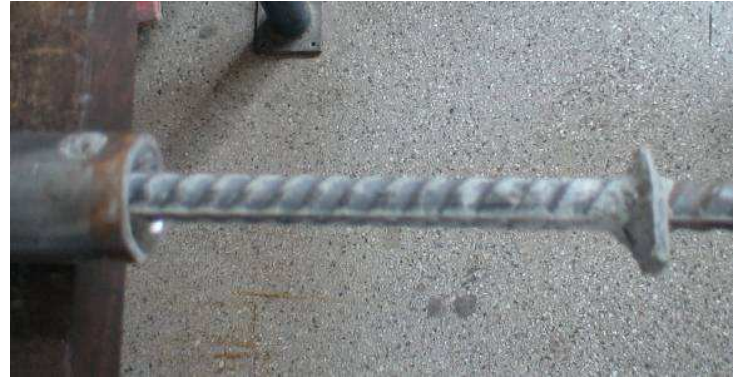

(b)

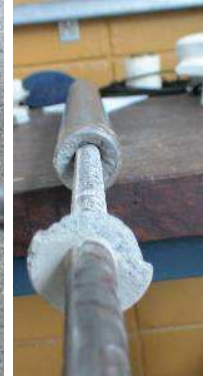

(c)

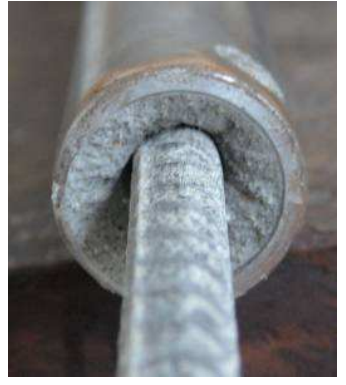

(d)

Figura 4.30 - Extremidade de ruína a) durante o ensaio, b) depois do ensaio barra deslizada do graute - vista lateral, c) vista frontal e d) detalhe da interface tubo de aço-graute

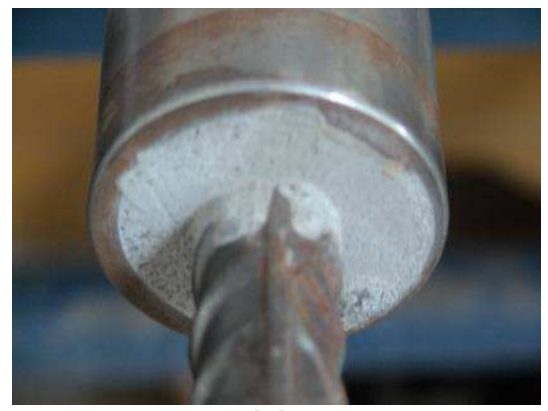

(a)

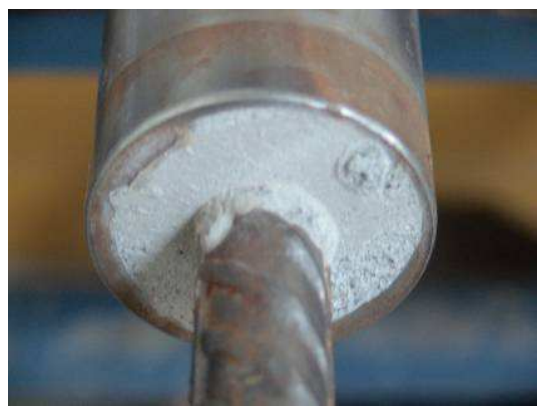

(b)

Figura 4.31 - Extremidade não rompida, inalterada

A causa provável desta diferença de resultados foi a falha no grauteamento, deixando algum espaço vazio, sem o preenchimento completo do tubo, diminuindo a resistência de aderência entre a barra e o graute. Por isso essa amostra foi desprezada na análise e a média foi calculada considerando as amostras 45T16EC9.5-200A e 45T16EC9.5-200B. ( Figura 4.32)

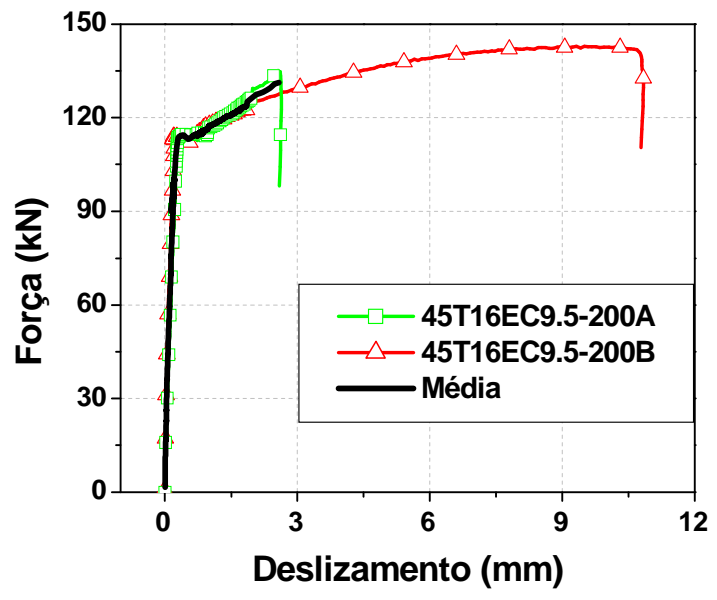

Figura 4.32 - Média da emenda 45T16EC9.5-200

Entre as amostras da série 45T16EE-200, a emenda A foi instrumentada com extensômetros ao longo do tubo e da barra, além dos dois transdutores de deslocamento. (Figura 4.33 e 4.34) 


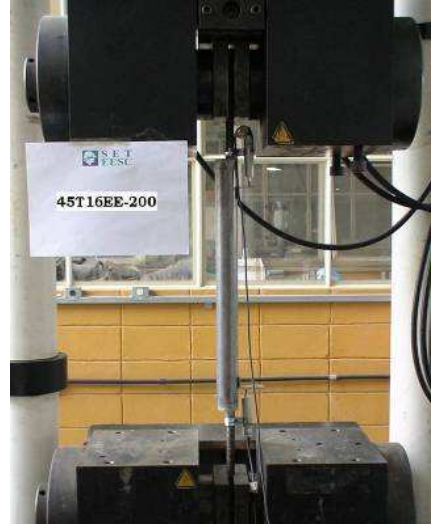

(a)

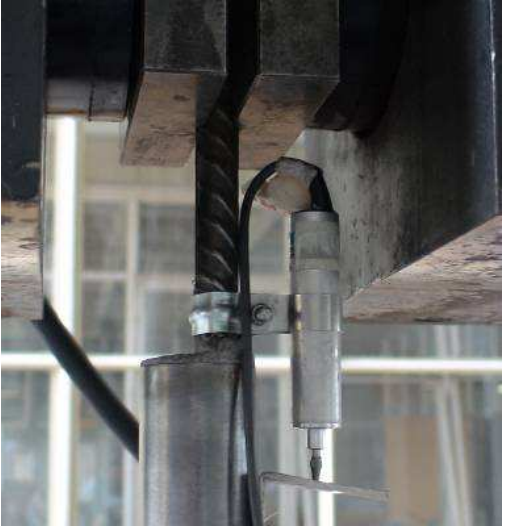

(b)

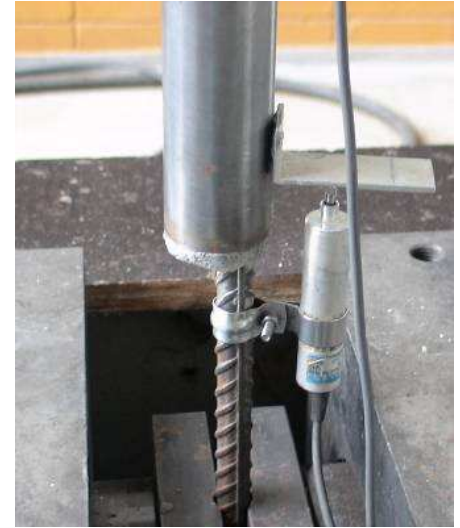

(c)

Figura 4.33 - Emenda 45T16EC9.5-200 a) geral, b) transdutor da extremidade de carga e c) transdutor da extremidade de reação

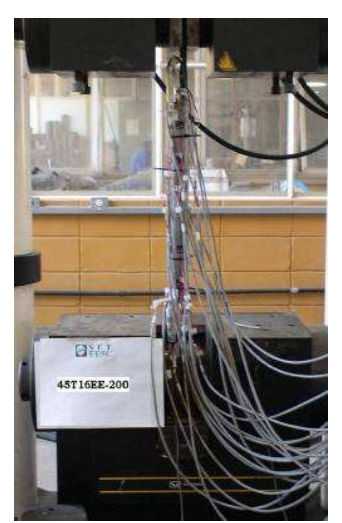

(a)

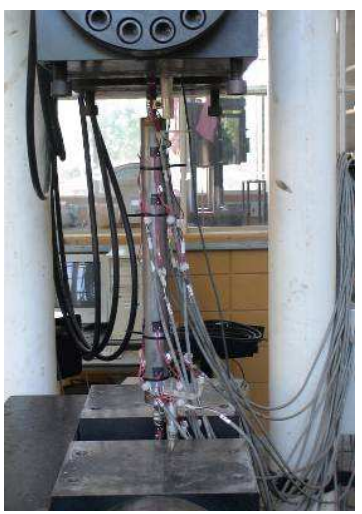

(b)

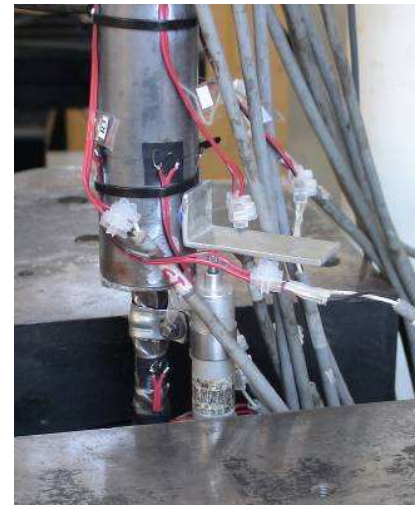

(c)

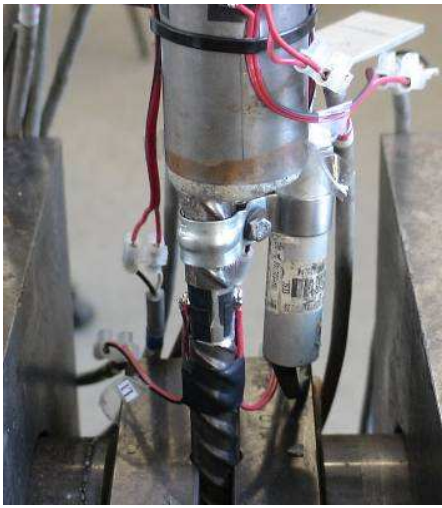

(d)

Figura 4.34 - Amostra 45T16EE-200A instrumentada a) vista frontal, b) vista lateral e c) e d) detalhe da extremidade de reação

A Figura 4.35 ilustra o comportamento das curvas tensão vs. deformação dos extensômetros colados na barra da amostra 45T16EE-200A. Observa-se um comportamento similar entre os extensômetros de ambas as extremidades, típico do aço CA-50. Os extensômetros registraram a última medição à tensão de $510 \mathrm{MPa}$ quando se descolaram, fornecendo valores inválidos.

A Figura 4.36 ilustra o comportamento das curvas tensão vs. deformação dos extensômetros colados longitudinalmente no tubo da amostra 45T16EE-200A. Observa-se um comportamento similar em ambas as extremidades. Os extensômetros centrais localizados na posição do tubo onde a barra está encostada (L6 e L12) obtiveram maiores deformações. 

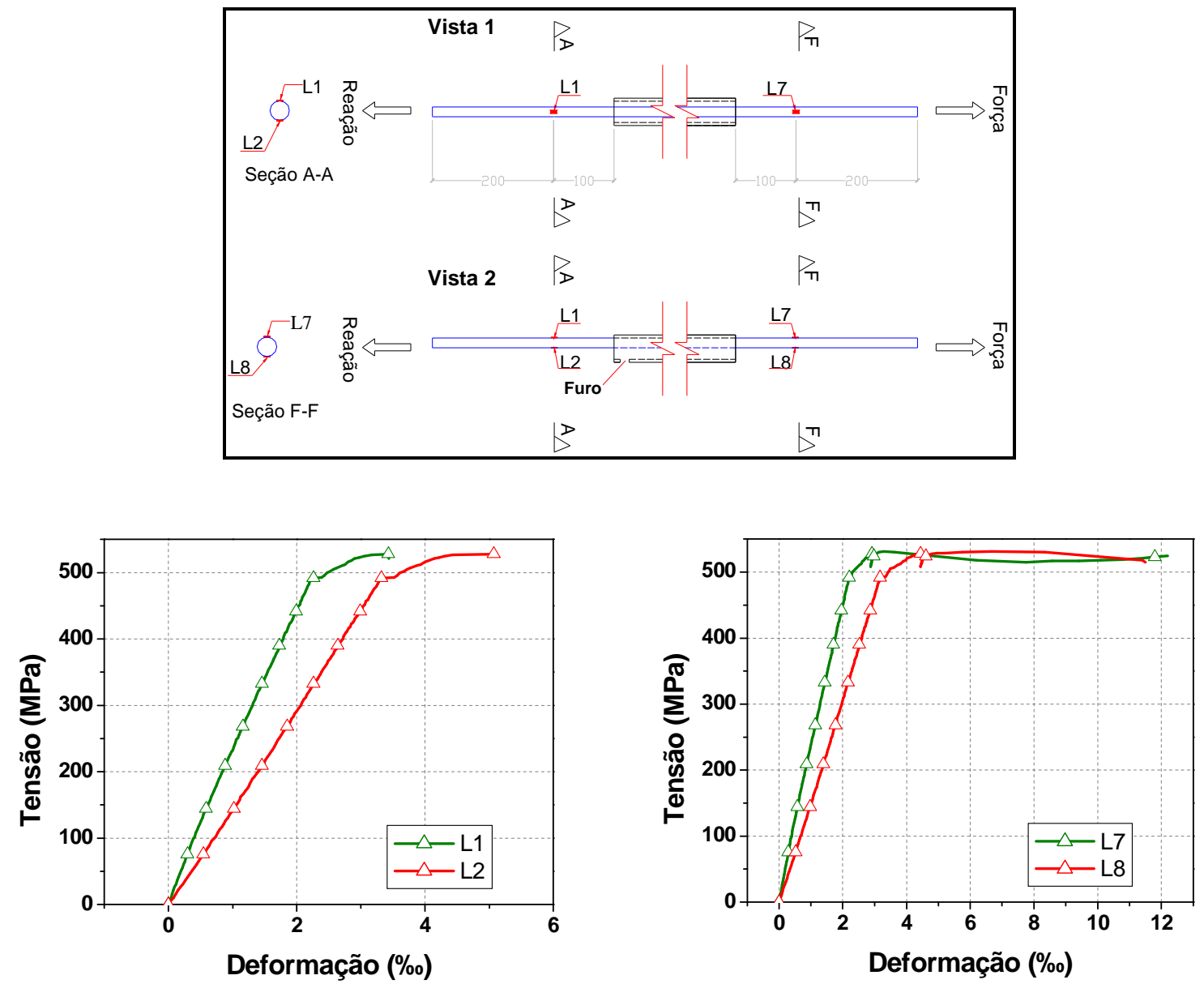

Figura 4.35 - Curva tensão-deformação dos extensômetros longitudinais da barra da amostra 45T16EE-200A da a)extremidade de reação e b)extremidade de carregamento

A deformação máxima é atingida na tensão última nos extensômetros próximos ao centro do tubo (L5, L6, L11 E L12). Diferente da deformação máxima nos extensômetros extremos que é atingida na tensão de $570 \mathrm{MPa}$. A partir da tensão última, há diminuição brusca da deformação, aparecendo compressão, com a diminuição da tensão até ocorrer a ruptura da barra.

A Figura 4.37 ilustra o comportamento das curvas tensão vs. deformação dos extensômetros colados na circunferência ao longo do tubo da amostra 45T16EE-200A. Observa-se pouca deformação, com compressão até se atingir o ponto de escoamento da barra de aço, aparecendo tração e em seguida há um alívio nas tensões no tubo, correspondente ao escoamento da barra de aço. 

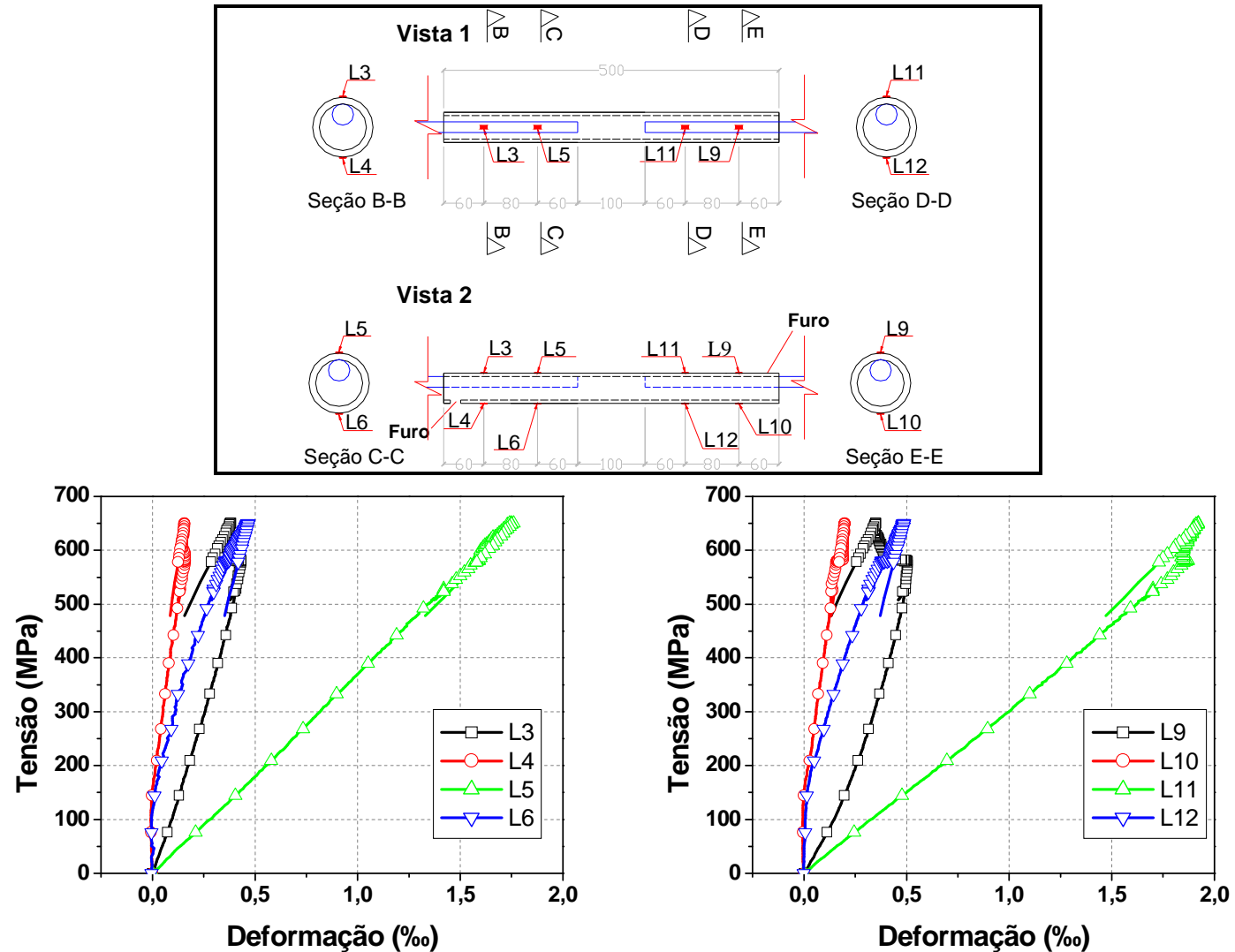

Figura 4.36 - Curva tensão-deformação dos extensômetros longitudinais da amostra 45T16EE-200A da a)extremidade de reação e b)extremidade de carregamento
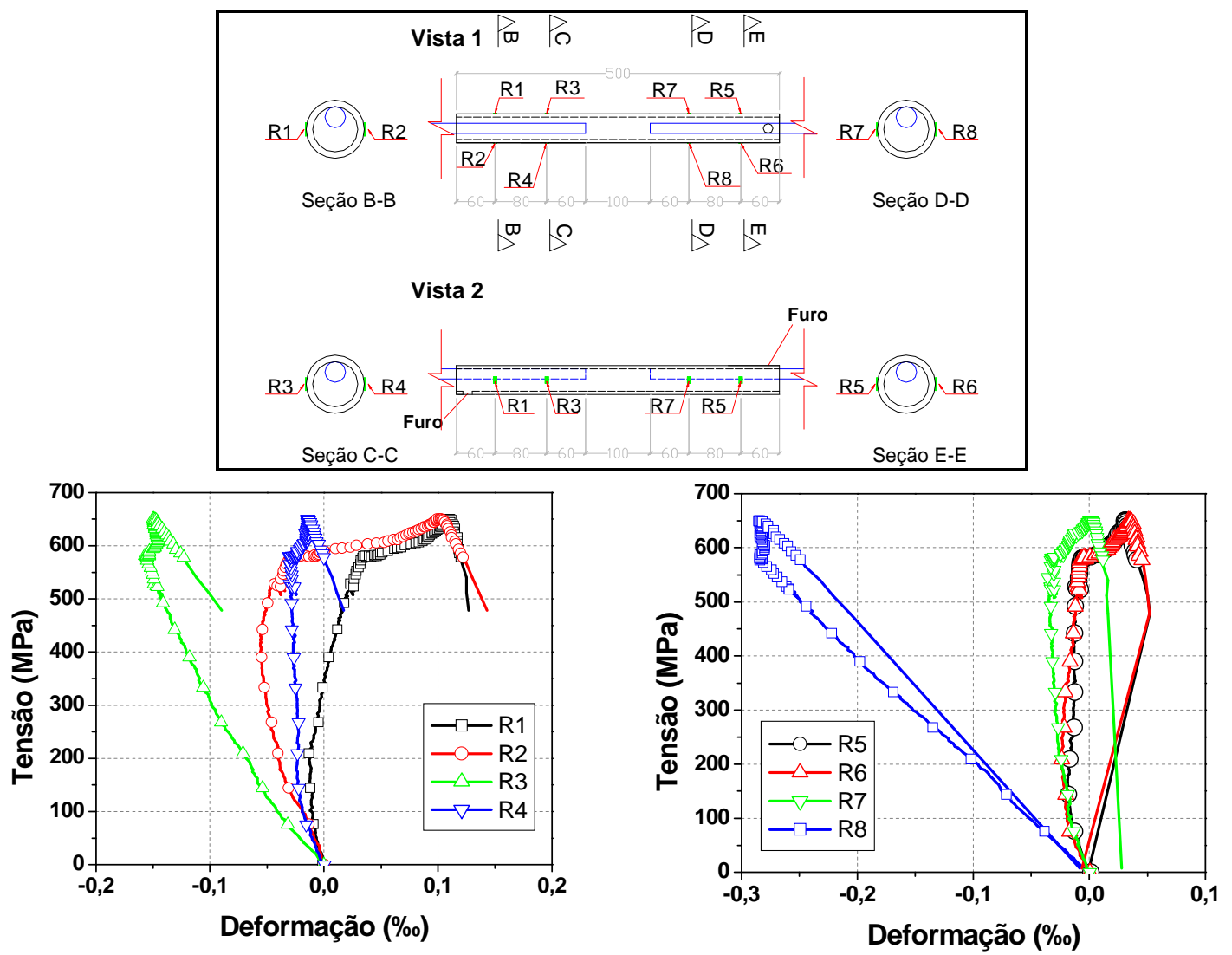

Figura 4.37 - Curva tensão-deformação dos extensômetros circunferenciais da amostra 45T16EE$200 \mathrm{~A}$ da a)extremidade de reação e b)extremidade de carregamento 
A Figura 4.38 ilustra o comportamento das curvas força vs. deslizamento para as amostras 45T16EE-200A e 45T16EE-200B, com deslizamentos medidos pelos transdutores.
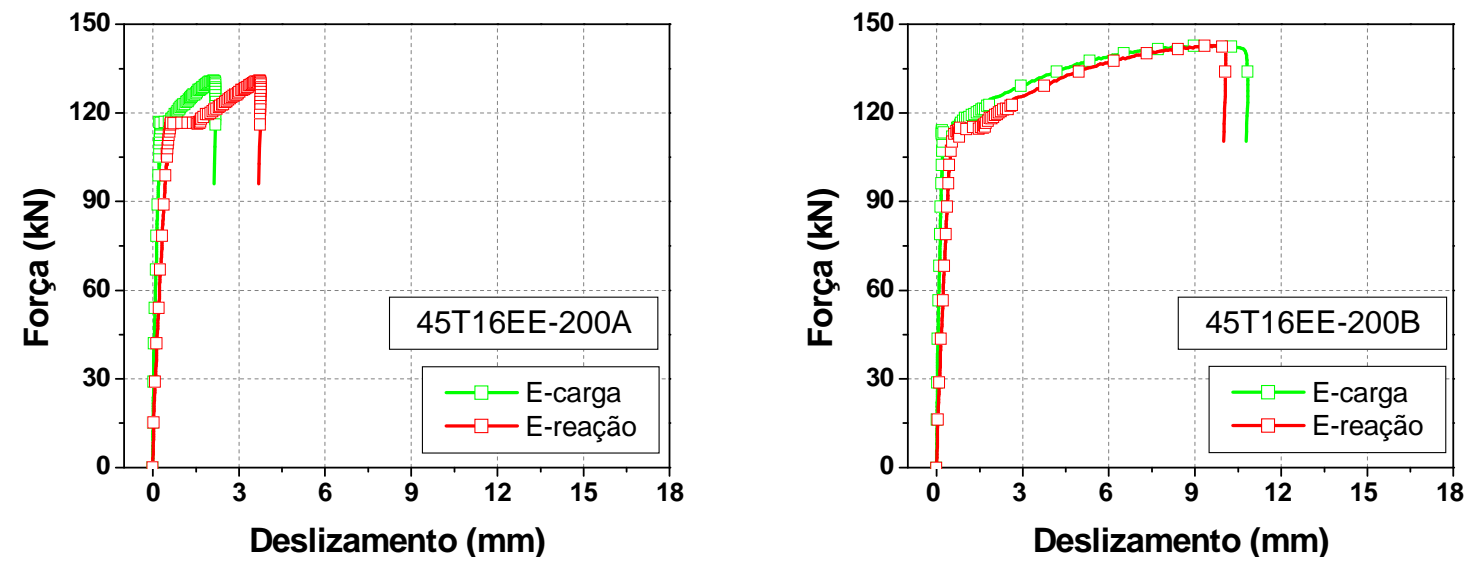

Figura 4.38 - Curva força vs. deslizamento das amostras 45T16EE-200A e 45T16EE-200B

A partir da curva da emenda 45T16EE-200A na Figura 4.38, observa-se um comportamento similar entre as duas extremidades. Após a força última de $131 \mathrm{kN}$ ter sido atingida, não foi admitido mais acréscimo de força, significando que foi atingido o limite máximo da capacidade da ligação e constatando a ruína na extremidade de reação. Em ambas as extremidades houve redução do valor da força aplicada, com deslizamento constante. No caso da extremidade de carga isso foi devido à perda de rigidez da outra extremidade que se rompeu. E nesta extremidade rompida, foi devido à estricção e consequente ruptura da barra de aço ter ocorrido na posição que foi colado o extensômetro nela (Figura 4.39) e este posicionamento ser fora do ponto de medição do transdutor de deslocamento. Como a seção transversal da barra de aço neste ponto estava menor que as demais, devido à necessidade de lixá-la, tornando-a lisa para melhor captação dos dados pelo extensômetro, a ruptura ocorreu neste ponto à força de $96 \mathrm{kN}$.

A partir da curva da emenda 45T16EE-200B na Figura 4.38, observa-se um comportamento similar entre as duas extremidades. Após a força última de $143 \mathrm{kN}$ ter sido atingida, não foi admitido mais acréscimo de força, significando que foi atingido o limite máximo da capacidade da ligação e constatando a ruína na extremidade de reação. Em ambas as extremidades houve redução do valor da força aplicada, com deslizamento constante. No caso da extremidade de carga isso foi devido à perda de rigidez da outra extremidade que se rompeu. Ocorreu a estricção da barra de aço e sua conseqüente ruptura. Houve um trecho descendente devido à estricção da barra ocorrer fora da área abrangente pelo transdutor.

A ruína observada foi por escoamento da barra de aço, atingindo, portanto, a capacidade máxima da emenda. Houve o aparecimento de algumas fissuras de fendilhamento e destacamento de camada de graute em ambas as extremidades, devido ao cisalhamento, mas que não foram suficientes para ocasionar a ruína da emenda. 


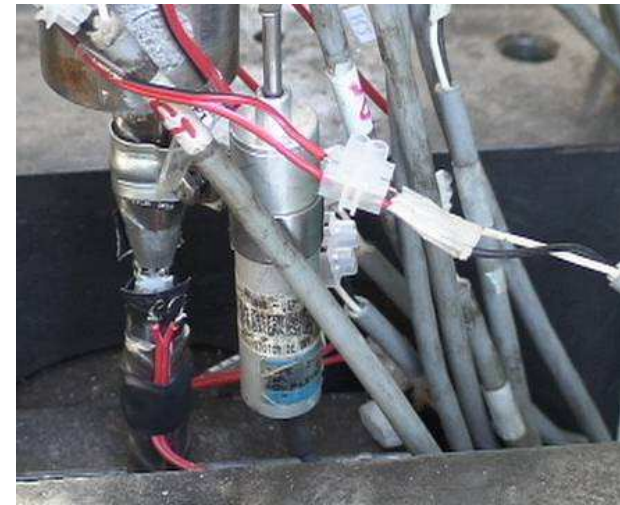

(a)

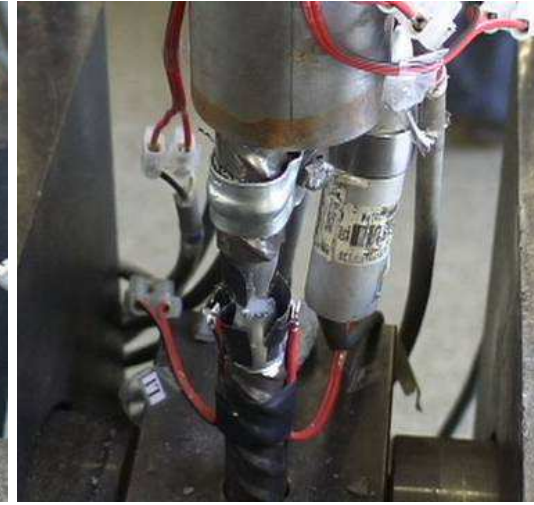

(b)

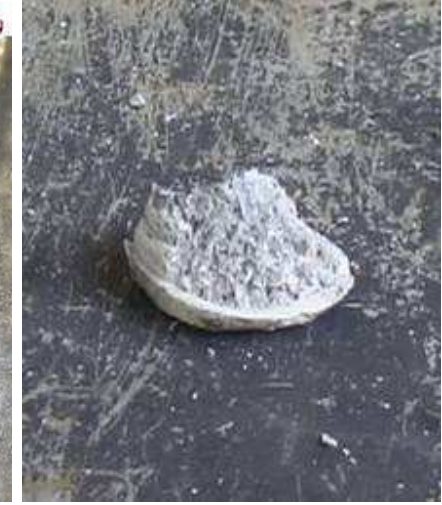

(c)

Figura 4.39 - a) e b) Ruptura da barra na posição do extensômetro, c) graute rompido desta mesma extremidade

A Figura 4.40 ilustra o comportamento das curvas força vs. deslizamento para as amostras 45T16EE-200C1e 45T16EE-200C2.
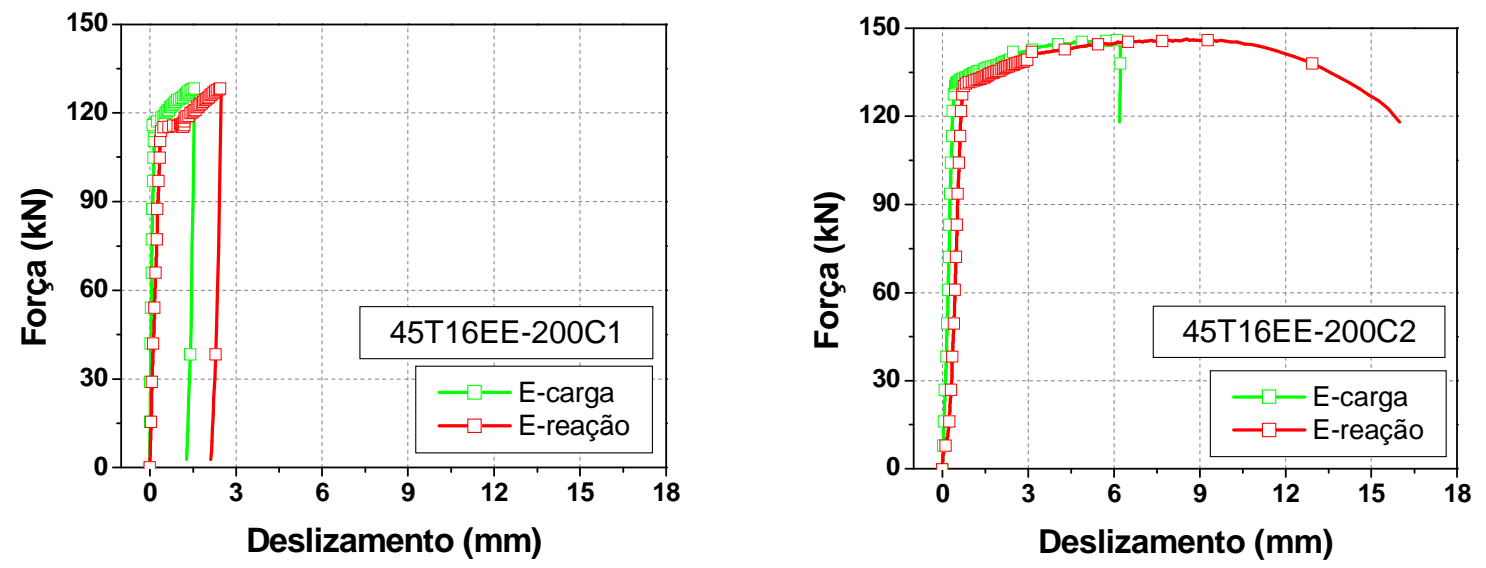

Figura 4.40- Curva força vs. deslizamento das amostras 45T16EE-200C1 e 45T16EE-200C2

Durante o ensaio a máquina INSTRON parou de funcionar em virtude da falta de energia elétrica. O gráfico 45T16EE-200C1 da Figura 4.40 ilustra isso. Após este problema ter sido contornado, reiniciou o ensaio e a curva está representada no gráfico 45T16EE200C2. Percebeu-se um comportamento satisfatório da emenda após o problema, sendo, portanto, o primeiro resultado desprezado.

Observa-se um comportamento similar entre as duas extremidades da emenda 45T16EE-200C2. Após a força última de $146 \mathrm{kN}$ ter sido atingida, não foi admitido mais acréscimo de força, significando que foi atingido o limite máximo da capacidade da ligação e constatando a ruína na extremidade de reação enquanto que na extremidade de carga houve redução do valor da força aplicada, com deslizamento constante, devido à perda de rigidez da outra extremidade. Houve um trecho descendente correspondente à estricção da barra, onde a força começou a cair e ocorreu a ruptura da barra (Figura 4.41). 


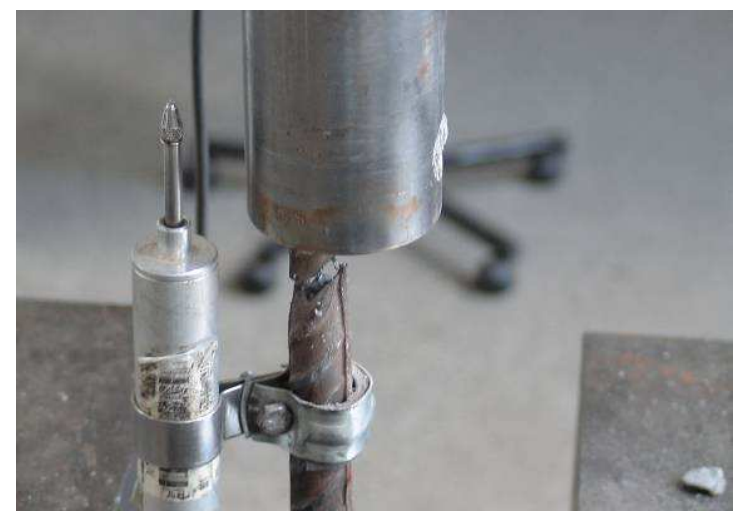

Figura 4.41 - Ruptura da barra de aço da emenda 45T16EE-200C2

A ruína observada foi por escoamento da barra de aço, atingindo, portanto, a capacidade máxima da emenda. Houve o aparecimento de algumas fissuras de fendilhamento e destacamento de camada de graute em ambas as extremidades, por causa do cisalhamento, mas que não foram suficientes para ocasionar a ruína da emenda (Figura 4.42).
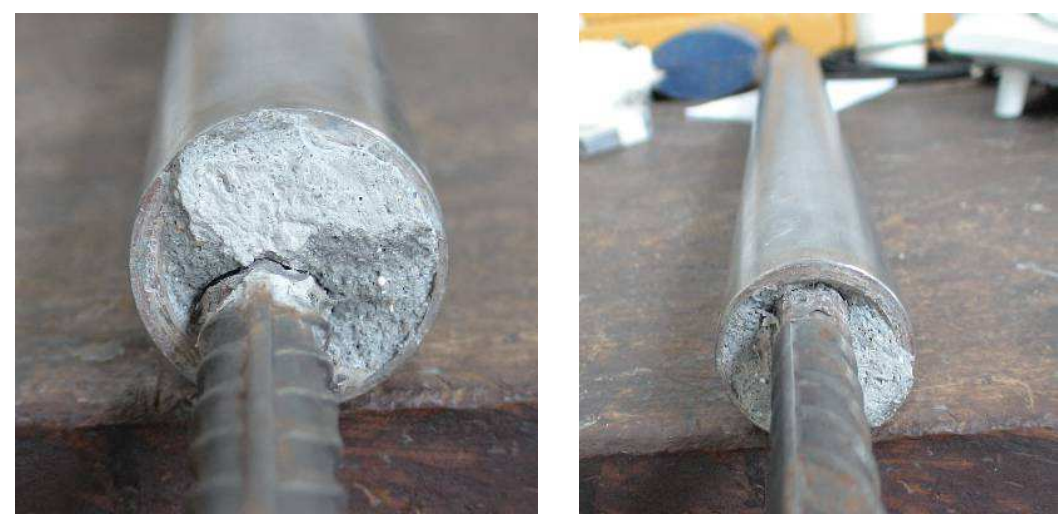

Figura 4.42 - Extremidade não rompida

A Figura 4.43 ilustra a média entre os resultados da emenda 45T16EE-200 para comparação com as outras emendas.

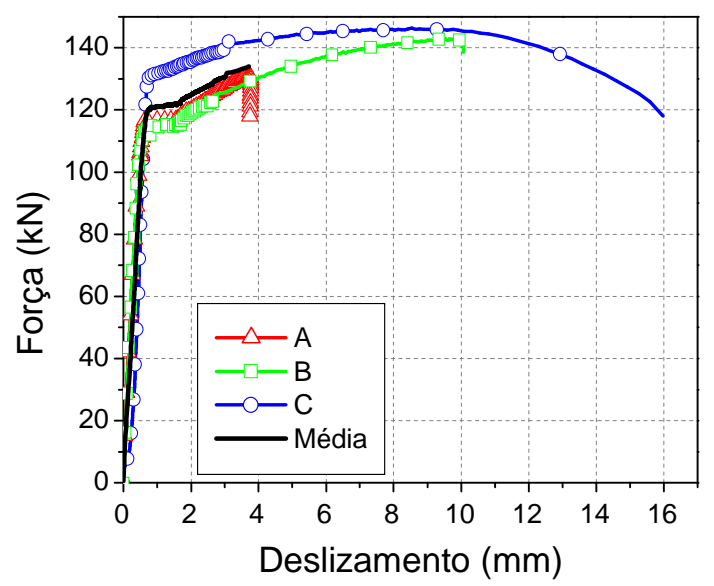

Figura 4.43 - Força vs. deslizamento da emenda 45T16EE9.5-200 


\subsubsection{Resultados das emendas da Série 2}

A Figura 4.44 ilustra o comportamento das curvas força vs. deslizamento para as amostras 50T16EC11-200A, 50T16EC11-200B, 50T16EC11-200C e da média deles. Observa-se um comportamento similar entre as três emendas. Após a força última ter sido atingida (144 kN, $145 \mathrm{kNe} 144 \mathrm{kN}$, respectivamente para as amostras 50T16EC11-200A, 50T16EC11-200B e 50T16EC11-200C), não foi admitido mais acréscimo de força, significando que foi atingido o limite máximo da capacidade da ligação e constatando a ruína, que, exceto para a amostra 50T16EC11-200B, ocorreu na extremidade de reação. $\mathrm{Na}$ extremidade que não ocorreu a ruína, houve redução do valor da força aplicada, com deslizamento constante, devido à perda de rigidez da outra extremidade. Houve um trecho descendente correspondente à estricção da barra, onde a força começou a cair e ocorreu a ruptura da barra (Figura 4.45).
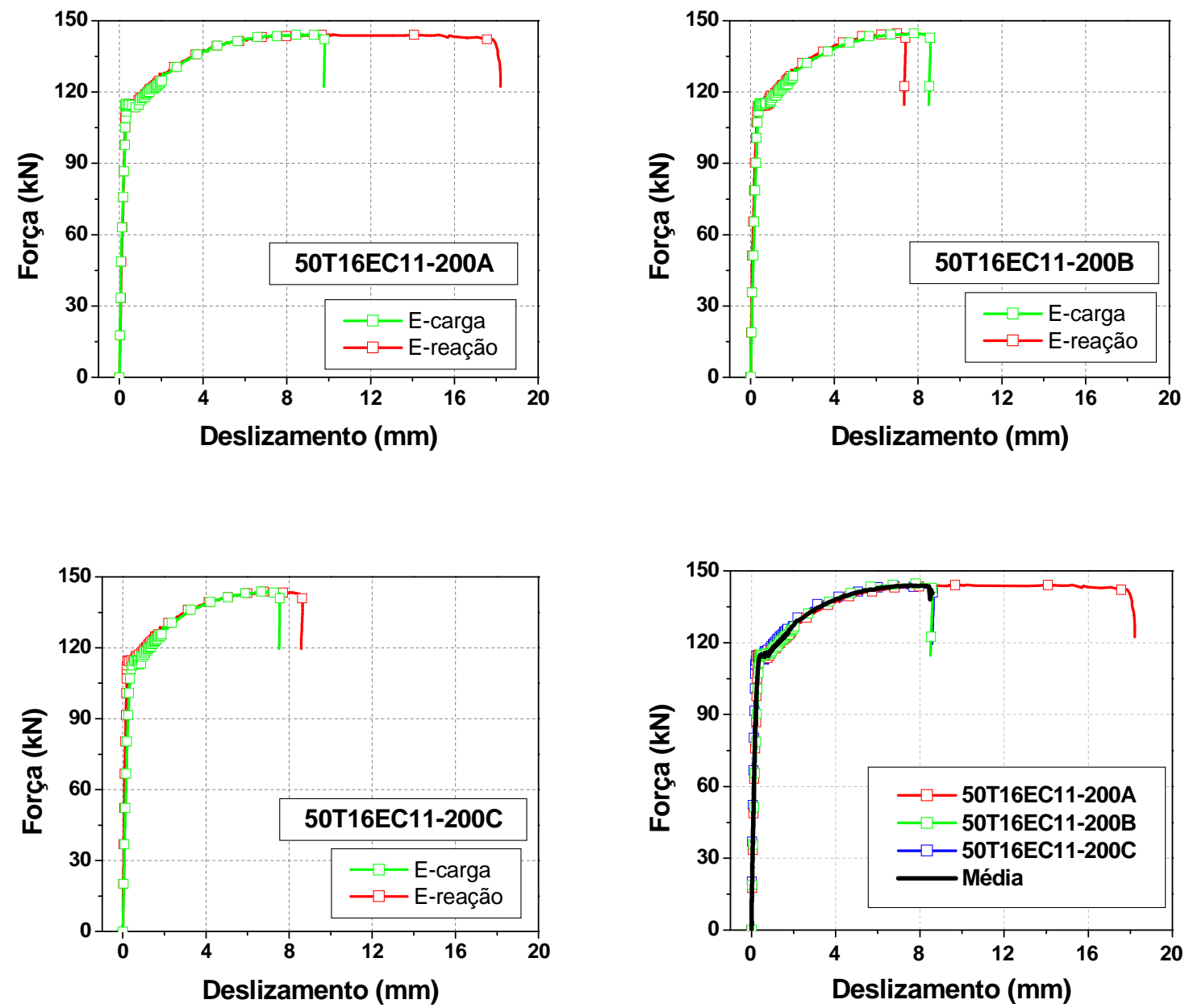

Figura 4.44 - Curva força vs. deslizamento das amostras 50T16EC11-200A, 50T16EC11-200B, 50T16EC11-200B e da média deles 


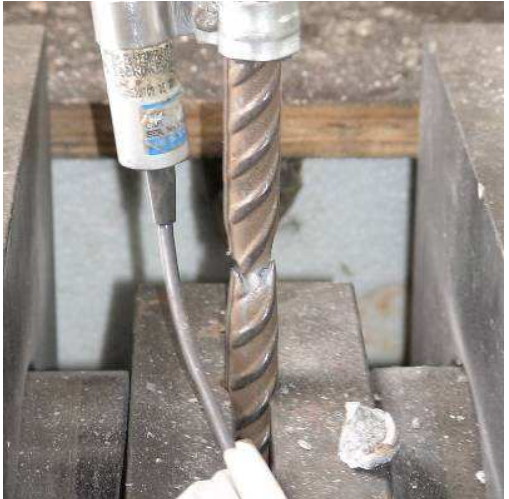

(a)

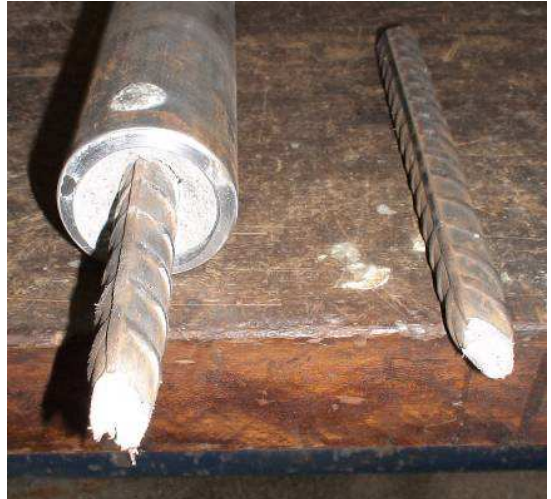

(b)

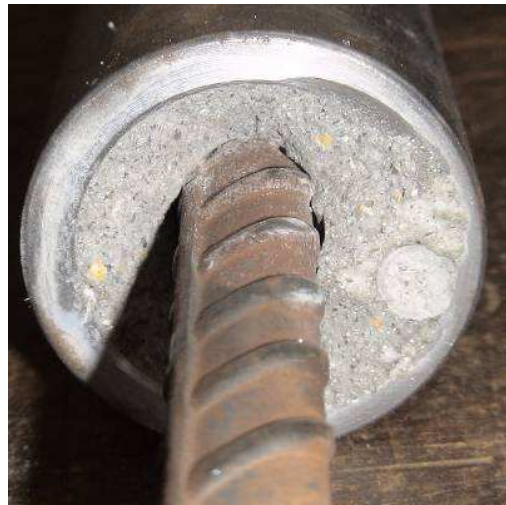

(c)

Figura 4.45 - a) e b) Ruptura da barra, c) detalhe da interface tubo de aço-graute

A ruína observada foi por escoamento da barra de aço, atingindo, portanto, a capacidade máxima da emenda. Durante o ensaio houve o aparecimento de algumas fissuras de fendilhamento e destacamento de camada de graute (Figura 4.46) em ambas as extremidades, devido ao cisalhamento, mas que não foram suficientes para ocasionar a ruína da emenda.
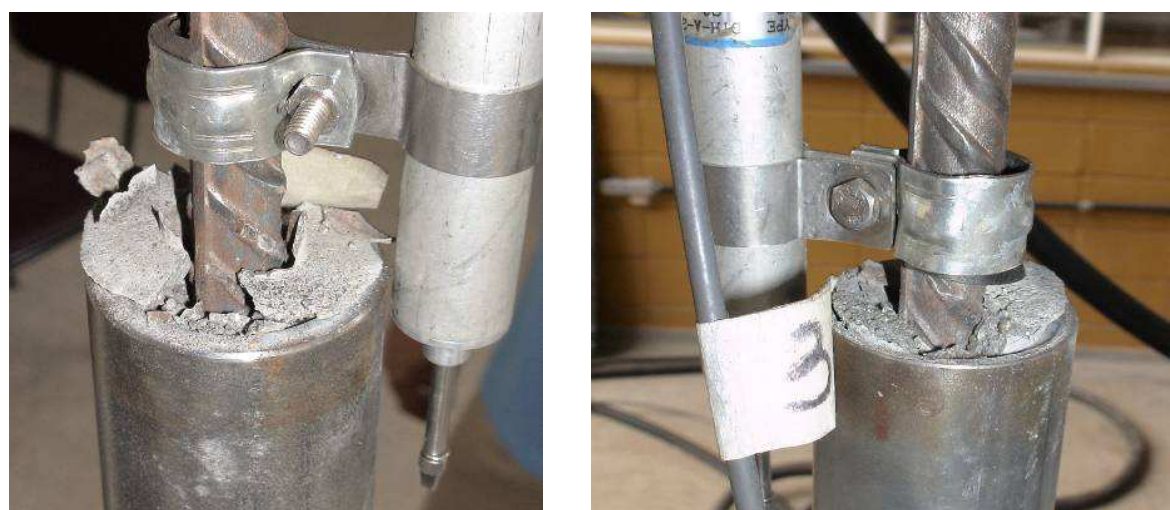

Figura 4.46 - Detalhe da ruptura do graute na extremidade não rompida

Entre as amostras da série 45T16CC9.5-200, a amostra 45T16CC9.5-200C foi instrumentada com extensômetros ao longo do tubo e da barra, além dos dois transdutores de deslocamento (Figura 4.47).

A aplicação do carregamento foi feita com a mesma velocidade do carregamento monotônico, neste caso, $0,016 \mathrm{~mm} / \mathrm{s}$.

A partir dos resultados de referência das amostras da série 45T16EC9.5-200, obtevese a força média de ruína de 139 kN.

Para a amostra 45T16CC9.5-200A, houve aplicação de ciclos com força última de $50 \%$ da força de ruína, no caso $70 \mathrm{kN}$, e força mínima de $10 \%$ da força de ruína (14 kN). Como não houve perda da resistência da emenda devido aos ciclos a que foi submetido, 
para as amostras seguintes, 45T16CC9.5-200B e 45T16CC9.5-200C, decidiu-se aumentar o valor da força máxima dos ciclos para $70 \%$ da força de ruína, no caso $97 \mathrm{kN}$, mas permanecendo com o valor da força mínima de $10 \%$ da força de ruína (14kN).

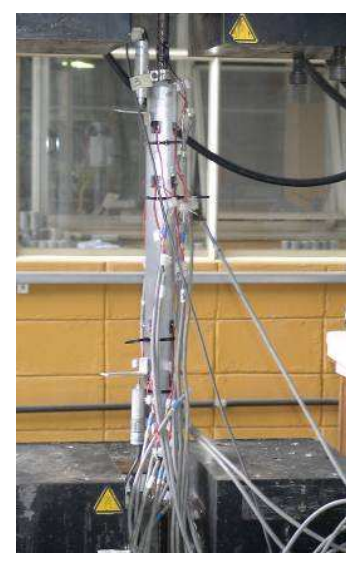

(a)

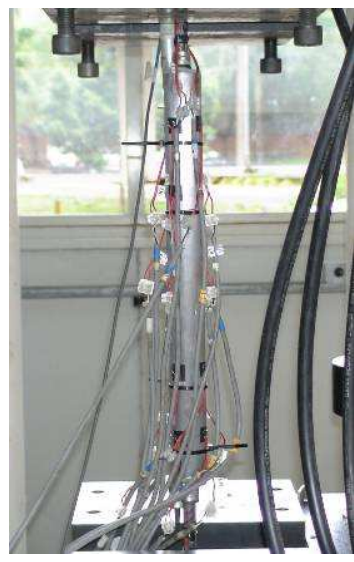

(b)

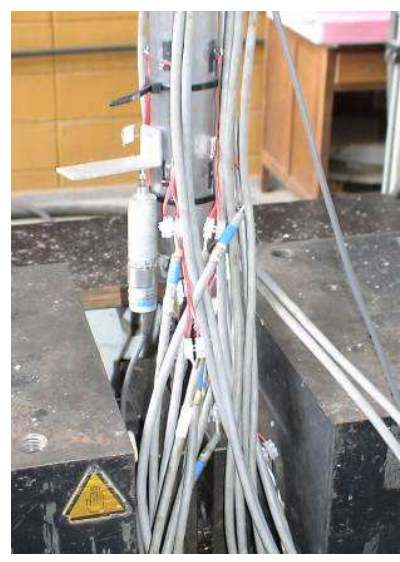

(c)

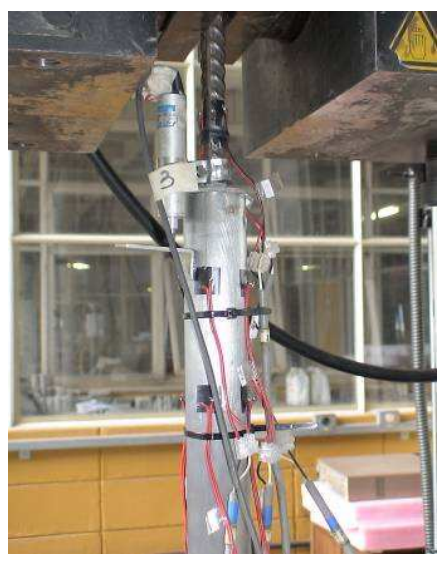

(d)

Figura 4.47 - Amostra 45T16CC9.5-200C instrumentada a) vista frontal, b) vista lateral, c) detalhe da extremidade de reação e d) detalhe da extremidade de carga

A Figura 4.48 ilustra o comportamento das curvas força vs. deslizamento para as amostras 45T16CC9.5-200A, 45T16CC9.5-200B e 45T16CC9.5-200C e da média entre as amostras 45T16CC9.5-200B e 45T16CC9.5-200C que tiveram mesmos parâmetros de carregamento cíclico.

A partir da Figura 4.48, observa-se um comportamento similar entre ambas as extremidades das três amostras. O intervalo A na amostra 45T16CC9.5-200C da Figura 4.48 não apresenta ciclos, devido a um erro técnico durante o ensaio, que ocasionou uma parada na leitura no milésimo ponto e além disso ultrapassou a força máxima estipulada para o ciclo. Logo que foi percebida a falha, foi solucionada e o ensaio continuou com a correta leitura dos pontos. Durante o carregamento cíclico, constata-se um comportamento elástico, com um deslizamento residual de 0,013 mm, em ambas as extremidades da amostra 45T16CC9.5-200A, de $0,064 \mathrm{~mm}$ e $0,046 \mathrm{~mm}$, para as extremidades de reação e de carga da amostra 45T16CC9.5-200B, respectivamente e de $0,16 \mathrm{~mm}$ e $0,42 \mathrm{~mm}$, para as extremidades de reação e de carga da amostra 45T16CC9.5-200C, respectivamente.. Seguiu-se com o carregamento monotônico e após a força última de $145 \mathrm{kN}$ ter sido atingida, não foi admitido mais acréscimo de força, significando que foi atingido o limite máximo da capacidade da ligação e constatando a ruína na extremidade de reação, para ambas as amostras. Na extremidade que não ocorreu a ruína, houve redução do valor da força aplicada, com deslizamento constante, que ocorreu por causa da perda de rigidez da outra extremidade. Houve um trecho descendente correspondente à estricção da barra, onde a força começou a diminuir e ocorreu a ruptura da barra. 

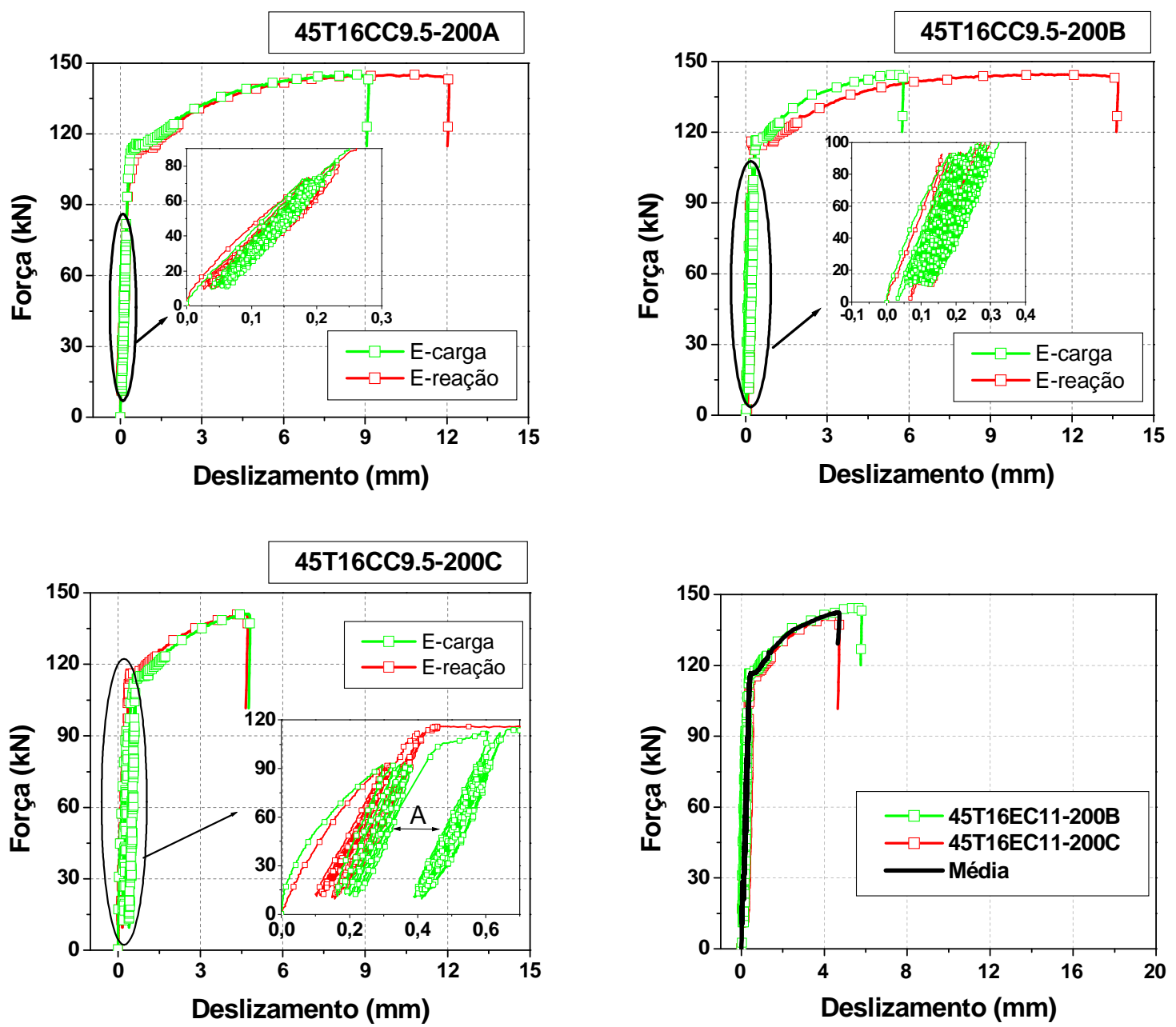

Figura 4.48- Curva força vs. deslizamento das amostras 45T16CC9.5-200A, 45T16CC9.5-200B e 45T16CC9.5-200C e da média da emenda 45T16CC9.5-200

A ruína observada foi por escoamento da barra de aço, atingindo, portanto, a capacidade máxima da emenda. Houve o aparecimento de algumas fissuras de fendilhamento e destacamento de camada de graute em ambas as extremidades, devido ao cisalhamento, mas que não foram suficientes para ocasionar a ruína da emenda.

A Figura 4.49 ilustra o comportamento das curvas tensão vs. deformação dos extensômetros colados na barra da amostra 45T16CC9.5-200C. Observa-se um comportamento similar entre os extensômetros de ambas as extremidades, típico do aço CA-50, com tração à medida que se aumenta a força e compressão com a diminuição da força. Pode ser observado o erro técnico que ocorreu durante o ensaio na curva do extensômetro L7, que apresenta um trecho sem ciclos, mas pertencente ao carregamento cíclico. O extensômetro L8 descolou à força de 103 kN (508 MPa de tensão) não fornecendo mais valores válidos. Os extensômetros da extremidade de reação (L1 e L2), onde houve a ruptura da barra, atingiram os seus limites de escoamento a $111 \mathrm{kN}$ e não registraram mais deslizamentos. À força de 114 kN ( $561 \mathrm{MPa}$ de tensão), já no trecho de carregamento 
estático, houve a máxima deformação registrada pelo extensômetro L7 de 1,34%, por um provável descolamento do mesmo, fornecendo valores inválidos.
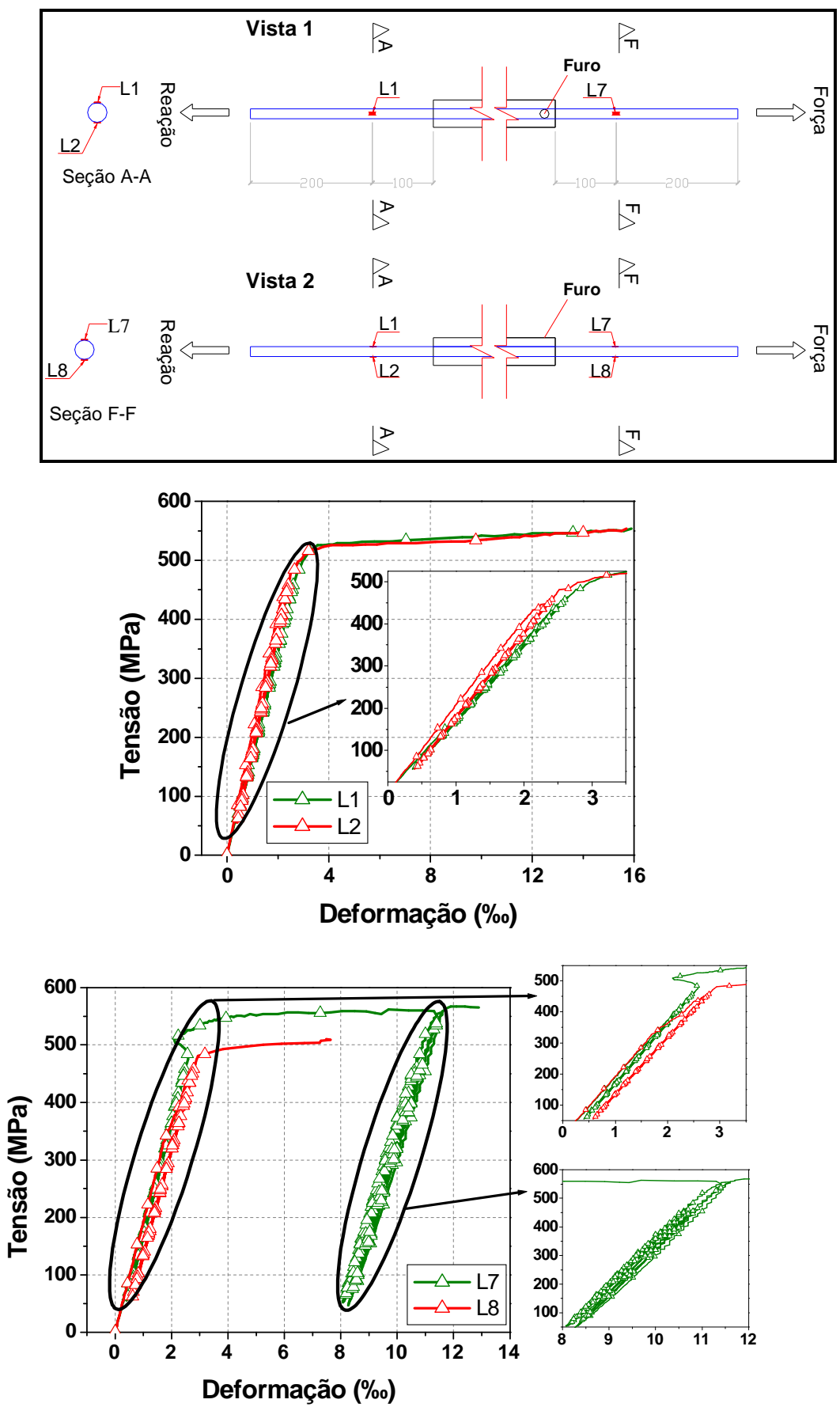

Figura 4.49 - Curva tensão-deformação dos extensômetros longitudinais da barra da amostra 45T16CC9.5-200C

A Figura 4.50 ilustra o comportamento das curvas tensão vs. deformação dos extensômetros colados longitudinalmente no tubo da amostra 45T16CC9.5-200A. 

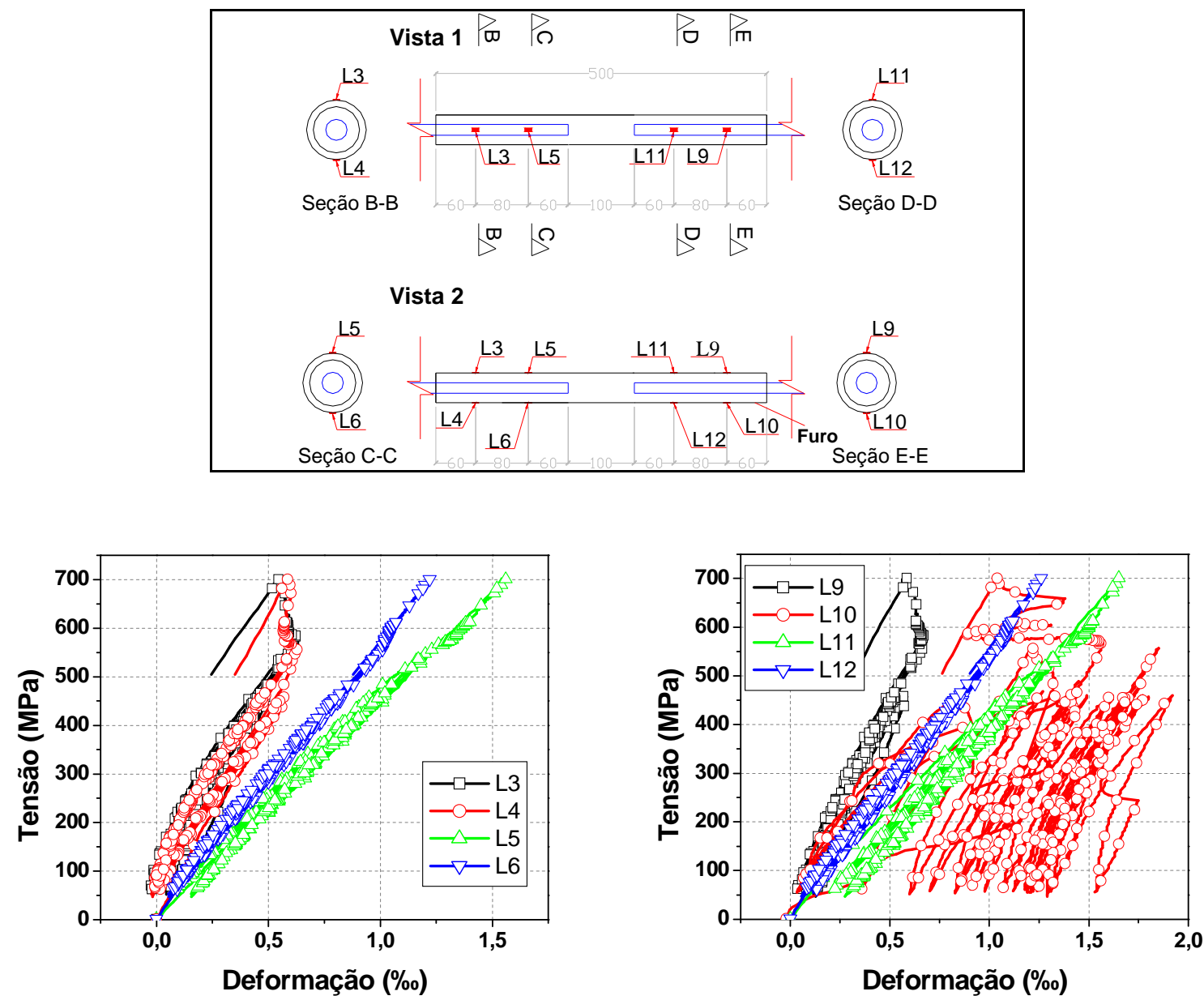

Figura 4.50 - Curva tensão-deformação dos extensômetros longitudinais da amostra 45T16CC9.5$200 \mathrm{~A}$ da a)extremidade de reação e b)extremidade de carregamento

Na Figura 4.50 observa-se um comportamento diferente do extensômetro L10, que sofreu perturbações devido à proximidade com o furo do tubo. Os demais extensômetros apresentaram durante o carregamento cíclico deformações de tração à medida que se aumentava a força e compressão com a diminuição da força. Também observa-se um comportamento similar entre os extensômetros L3, L4 e L9, bem como entre os extensômetros L5, L6, L11 e L12. Eles estão localizados na mesma posição, mas em emendas diferentes, ilustrando o mesmo comportamento em ambas extremidades. Após os ciclos, os extensômetros mais próximos às extremidades, L3, L4 e L9, apresentam um trecho de compressão com o aumento da força, exatamente durante a estricção da barra, até a ruína da emenda. Já os extensômetros mais próximos ao centro da emenda, L5, L6, L11 e L12, mesmo após os ciclos, apresentaram o mesmo comportamento com deformação de tração com o aumento da força até a ruína da emenda. Os extensômetros centrais obtiveram maiores deformações do que os localizados na extremidade do tubo.

A Figura 4.51 ilustra o comportamento das curvas tensão vs. deformação dos extensômetros colados na circunferência ao longo do tubo da amostra 45T16CC9.C-200A. 

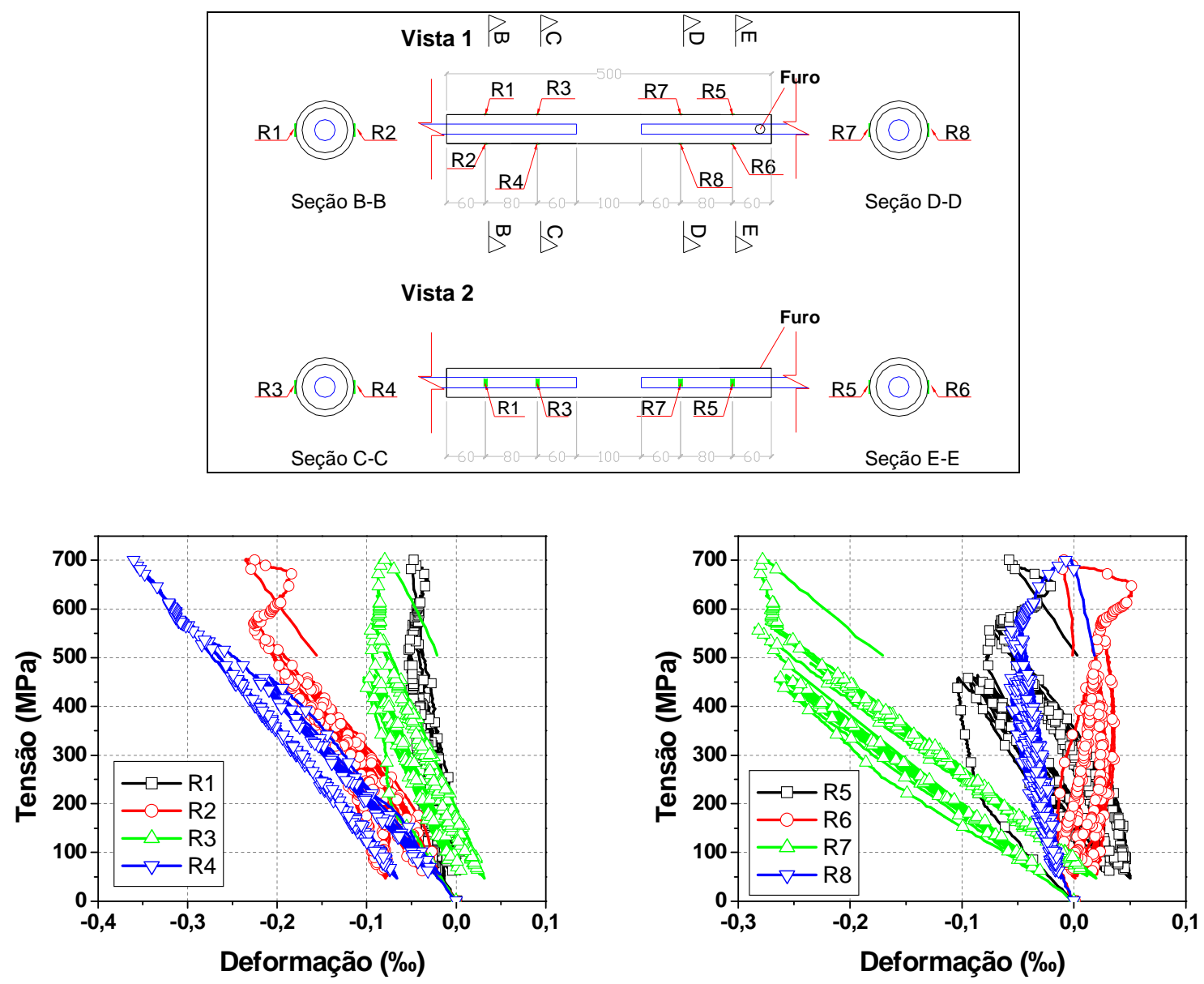

Figura 4.51 - Curva tensão-deformação dos extensômetros circunferenciais da amostra 45T16CC9.5-200A da a)extremidade de reação e b)extremidade de carregamento

Na Figura 4.51 observa-se um comportamento diferente do extensômetro R6, que sofreu perturbações devido à proximidade com o furo do tubo. Os demais extensômetros apresentaram durante o carregamento cíclico deformações de compressão à medida que se aumentava a força e de tração com a diminuição da força. Também observa-se um comportamento similar entre os extensômetros R4 e R7, bem como entre os extensômetros R3 e R8, que são diametralmente opostos entre si, significando um aparecimento de torção no tubo. Os extensômetros R4 e R7 obtiveram maiores deformações do que os demais.

\subsubsection{Resultados das emendas da Série 3}

A Figura 4.52 ilustra o comportamento das curvas força vs. deslizamento para as amostras 50T20EC9-200A, 50T206EC9-200B, 50T206EC9-200C e da média deles. 

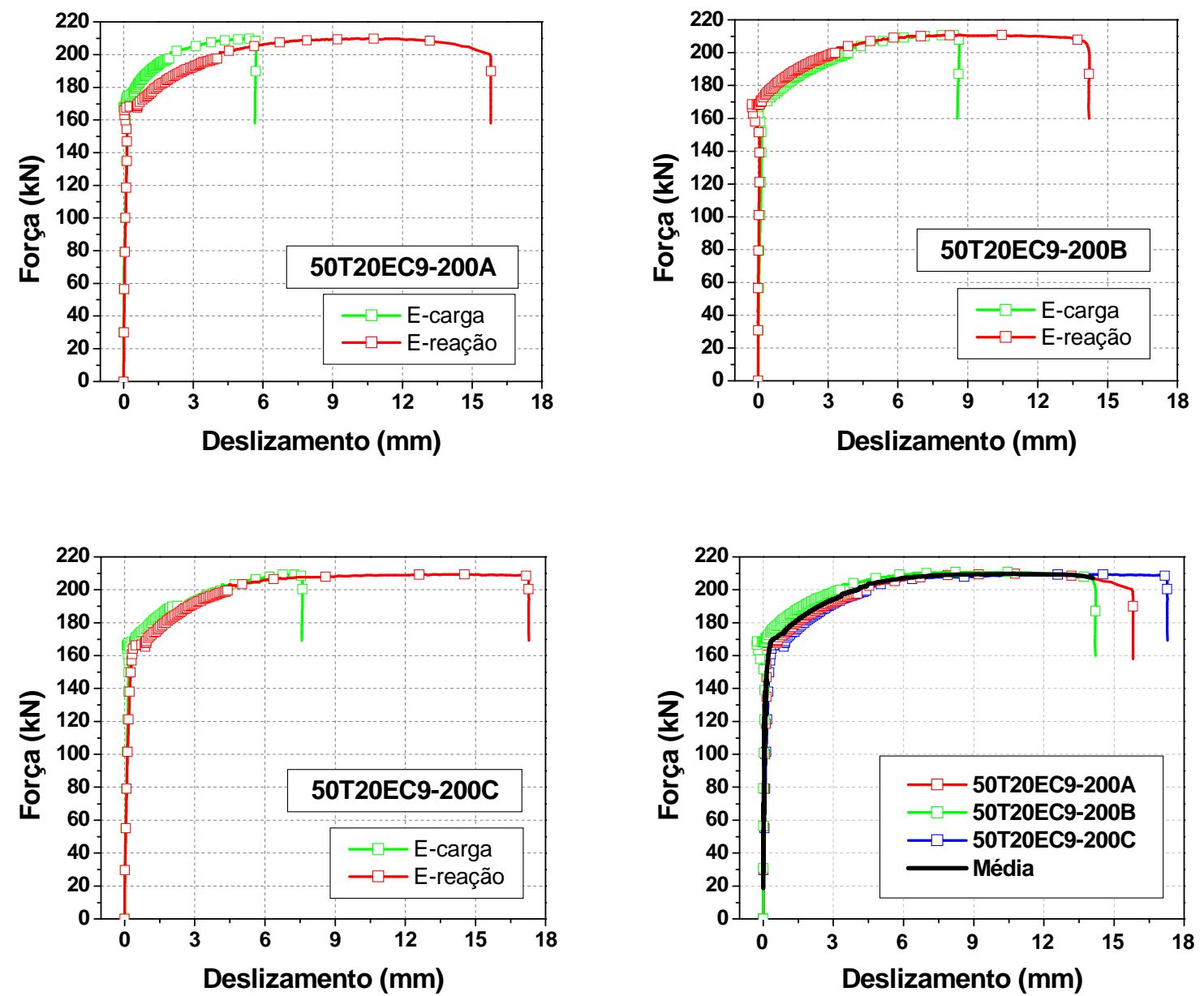

Figura 4.52- Curva força vs. deslizamento das amostras 50T20EC9-200A, 50T20EC9-200B, 50T20EC9-200C e da média delas

Observa-se na Figura 4.52 um comportamento similar entre as duas extremidades nas três amostras. Após a força última ter sido atingida (209 kN, 209 kN e 210 kN, respectivamente para as amostras 50T20EC9-200A, 50T20EC9-200B e 50T20EC9-200C), não foi admitido mais acréscimo de força, significando que foi atingido o limite máximo da capacidade da ligação e constatando a ruína na extremidade de reação, enquanto que na extremidade de carga houve redução do valor da força aplicada, com deslizamento constante, que ocorreu por causa da perda de rigidez da outra extremidade. Houve um trecho descendente correspondente à estricção da barra, onde a força começou a cair e ocorreu a ruptura da barra.

Apenas na amostra 50T20EC9-200C da série 50T20EC9-200, o furo foi posicionado na extremidade de reação, para verificar a sua influência na ruína.

A ruína observada foi por escoamento da barra de aço (Figura 4.53), atingindo, portanto, a capacidade máxima da emenda. Houve o aparecimento de algumas fissuras de fendilhamento e destacamento de camada de graute (Figura 4.54), em ambas as 
extremidades, devido ao cisalhamento, mas que não foram suficientes para ocasionar a ruína da emenda.
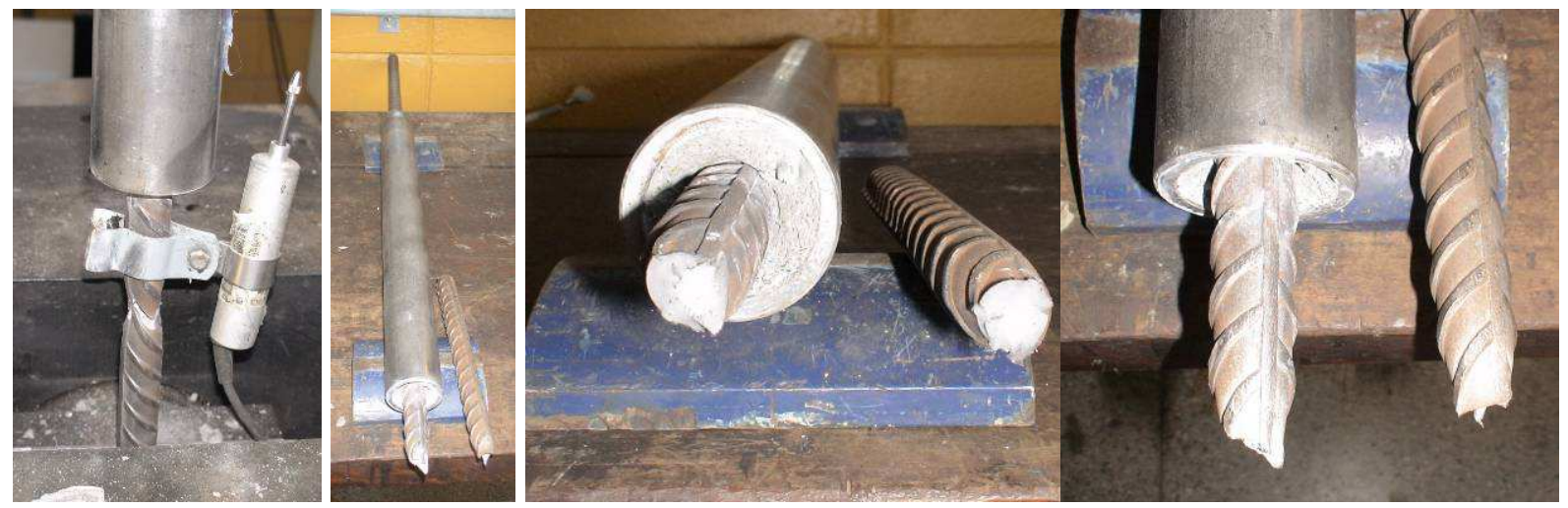

Figura 4.53- Ruptura da barra de aço
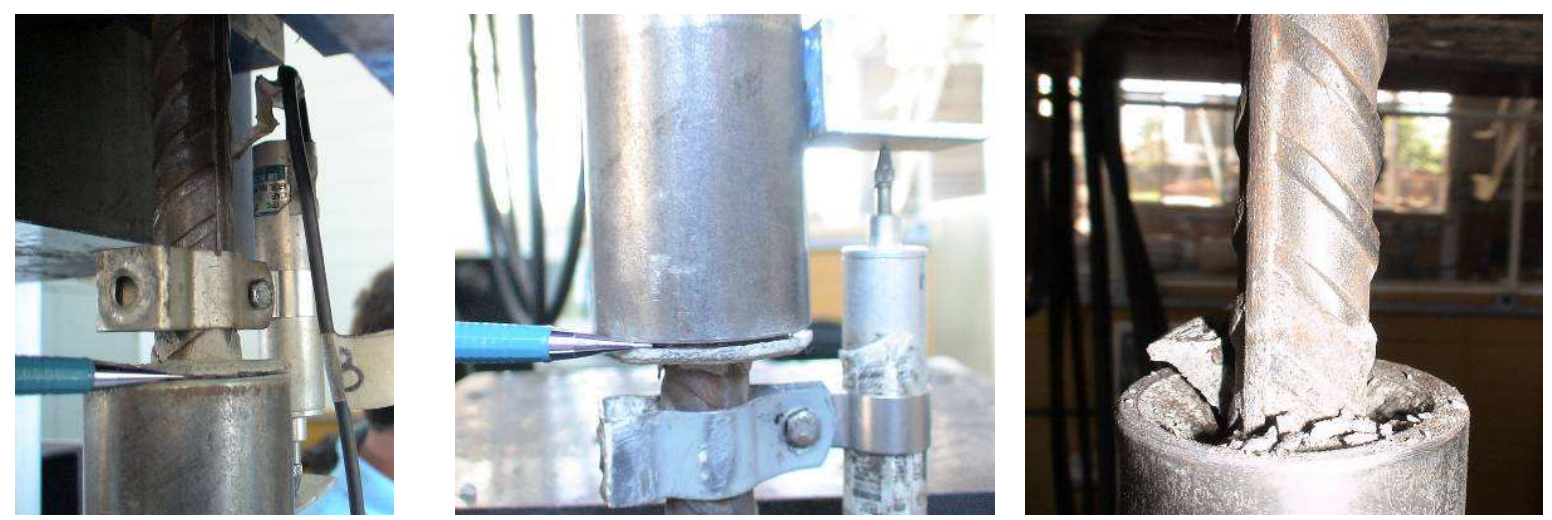

Figura 4.54- Deslizamento e ruptura do graute

Como o comportamento das três amostras foi similar, a curva representativa da emenda 50T16EC11-200 será a média delas, observada na Figura 4.52.

A Figura 4.55 ilustra o comportamento da curva força vs. deslizamento para a amostra 57T25EC11-300A, 57T25EC11-300B e 57T25EC11-300C. Apenas na amostra 57T25EC11-300C da emenda 57T25EC11-300, o furo foi posicionado na extremidade de reação, para verificar a sua influência na ruína.

Já com relação à extremidade de ruína, exceto na amostra 57T25EC11-300A, todas as amostras atingiram a ruína na extremidade de carga. Após a força última ter sido atingida (239 kN, 247 kN e 241 kN, respectivamente para as amostras 57T25EC11-300A, 57T25EC11-300B e 57T25EC11-300C), não foi admitido mais acréscimo de força, significando que foi atingido o limite máximo da capacidade da ligação e constatando a ruína por escoamento do tubo de aço (Figura 4.56). O tubo rompeu na transição da parte lisa central da emenda para o trecho corrugado (Figura 4.56-b), destacando a fragilidade desta região. Após a ruína na amostra $C$, ainda se aplicou força para melhor visualização do modo de ruína, mostrando claramente a ruptura do tubo e ruptura do graute (Figuras 4.57-d e 
Figura 4.57). A superfície de graute das extremidades não apresentou nenhuma fissura nem ruína de graute (Figura 4.58).
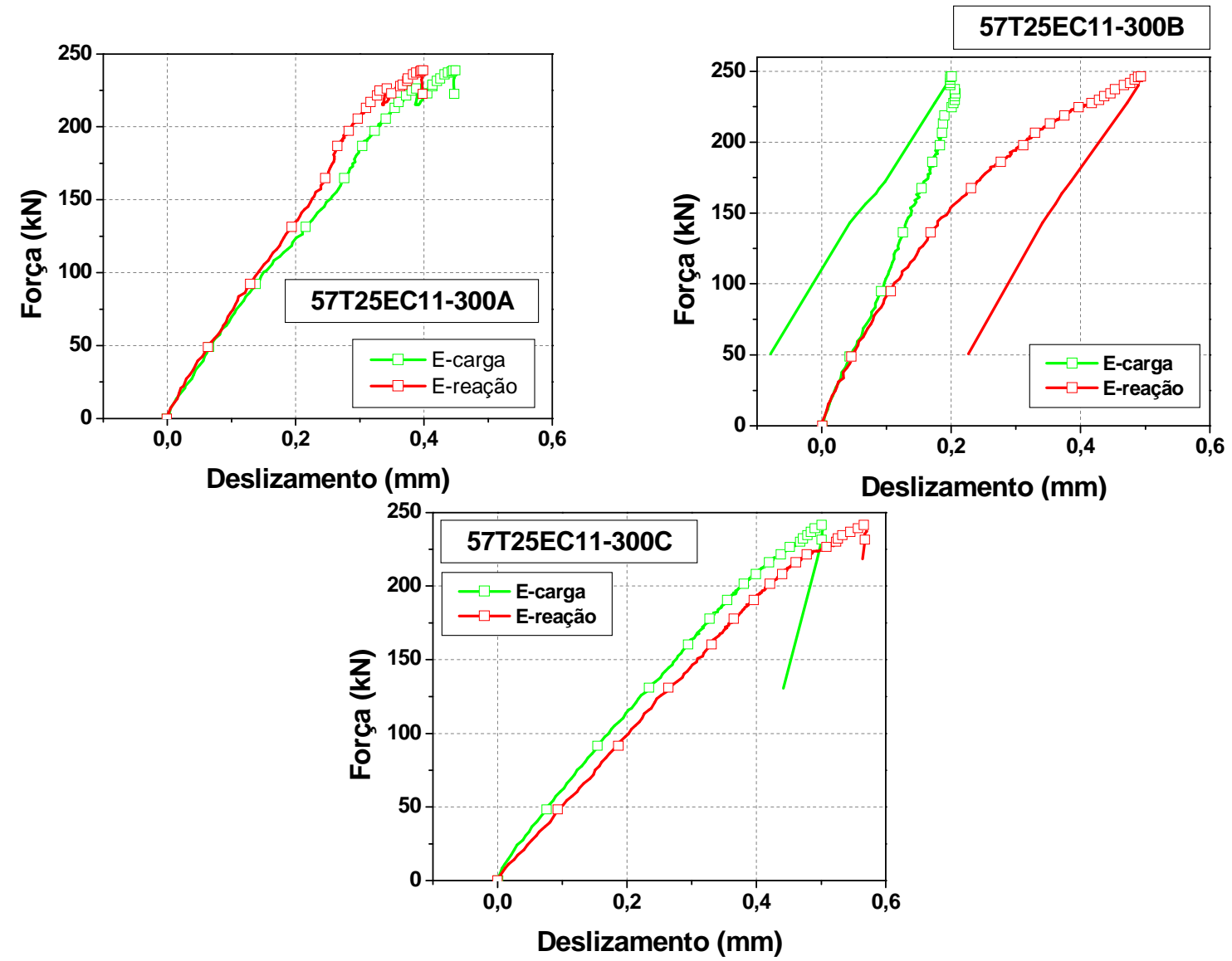

Figura 4.55 - Curva força vs. deslizamento das amostras 57T25EC11-300A, 57T25EC11-300B e 57T25EC11-300C

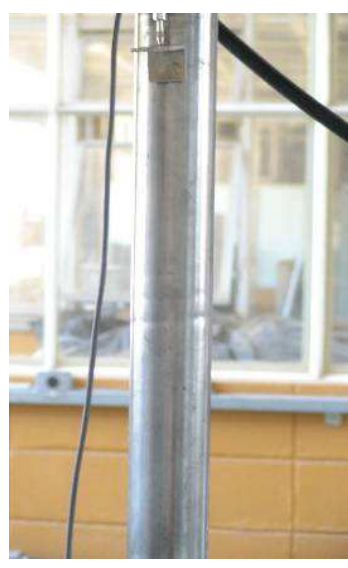

(a)

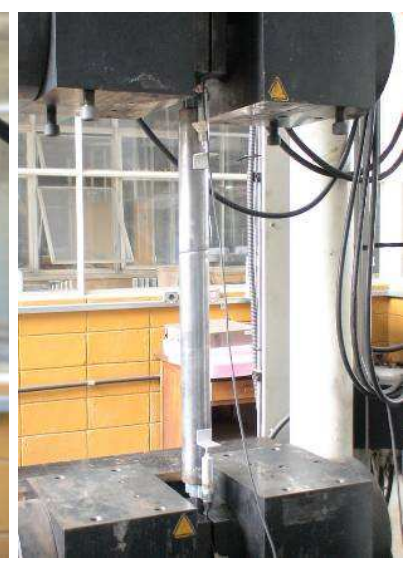

(b)

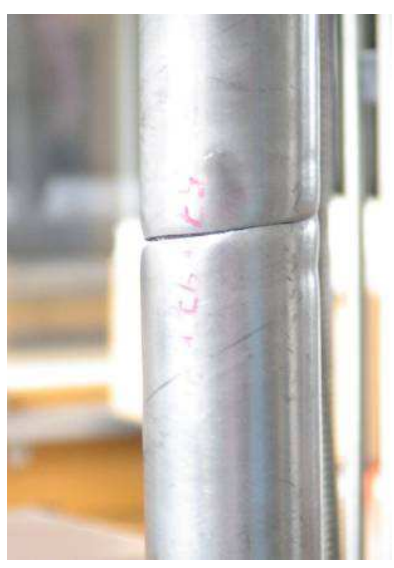

(c)

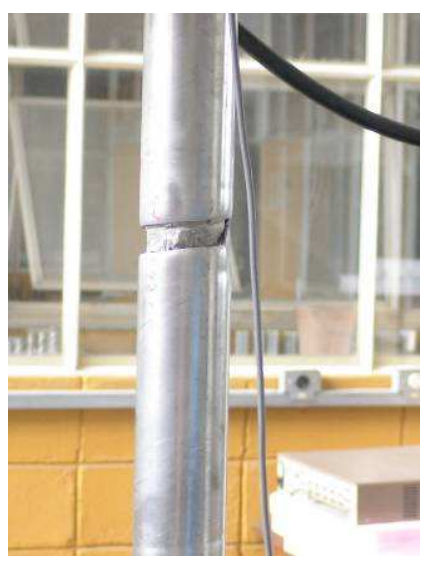

(d)

Figura 4.56 - Amostra 57T25EC11-300C a) durante o ensaio, estrição do tubo, b) e c) fim do ensaio,ruptura do tubo e d) detalhe da ruptura 

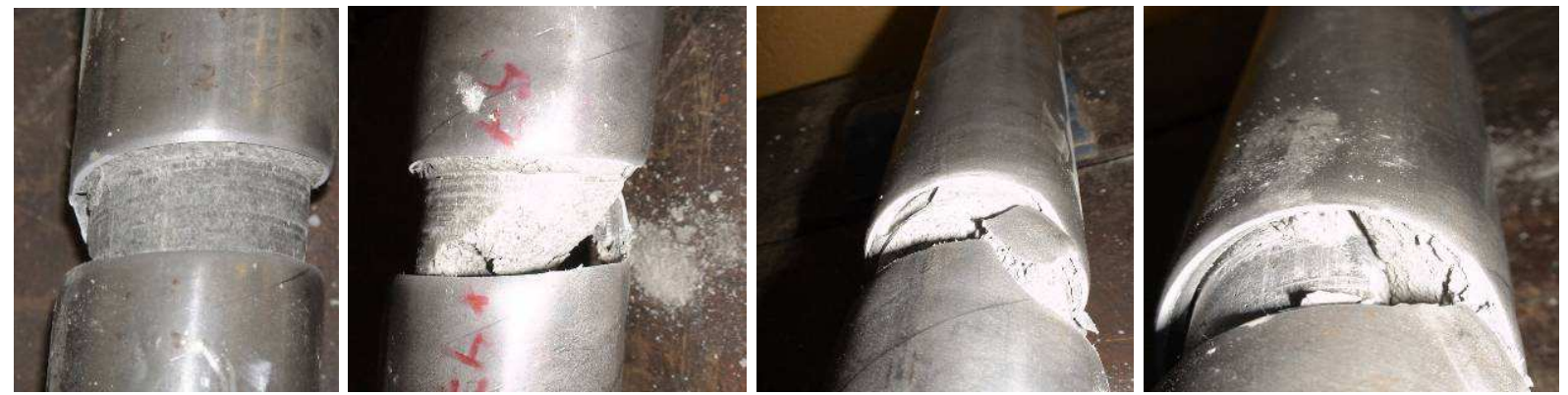

Figura 4.57 - Amostra 57T25EC11-300C, detalhe da ruptura do tubo e do graute

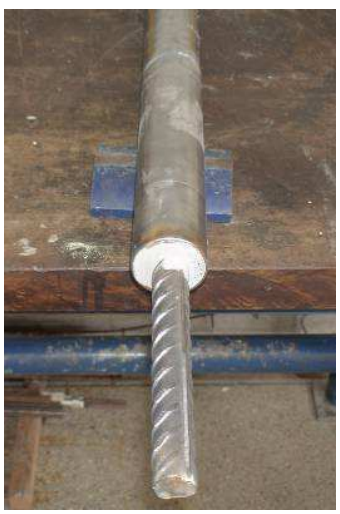

(a)

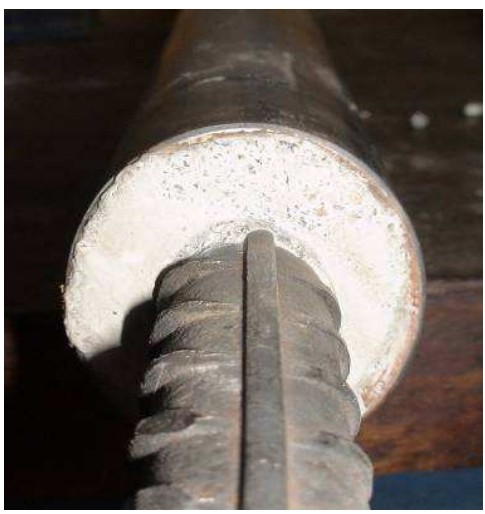

(b)

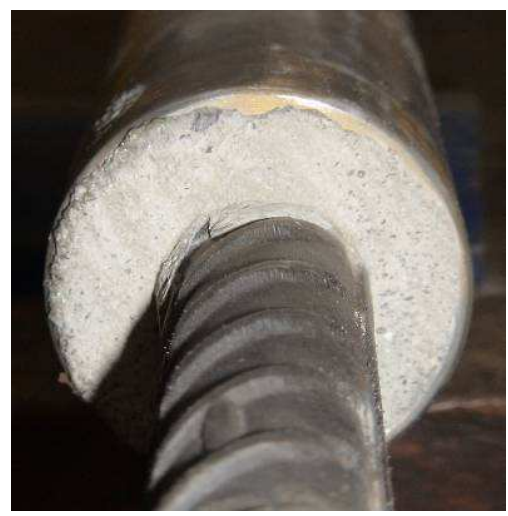

(c)

Figura 4.58 - Amostra 57T25EC11-300C, extremidade a) e b) de carga e c) de reação

\subsubsection{Resumo dos resultados}

A Tabela 4.10 apresenta um resumo dos resultados da série definitiva. 
Tabela 4.10 - Resumo dos resultados das emendas da série definitiva

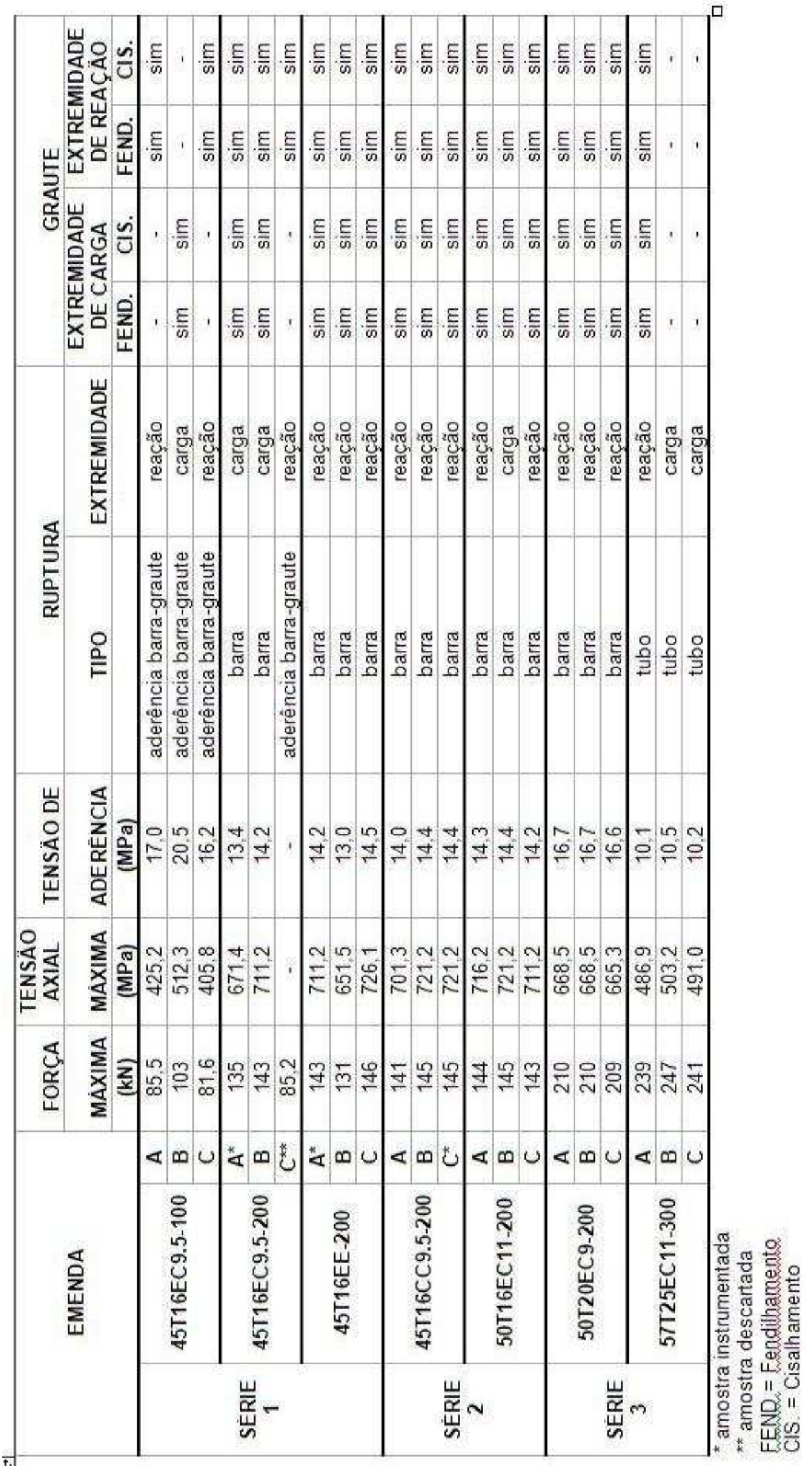




\subsubsection{Comparação entre as emendas}

Os resultados são analisados e comparados conforme a influência de alguns parâmetros relevantes, como o carregamento (monotônico ou cíclico), diâmetro da barra (16 $\mathrm{mm}$ ou $20 \mathrm{~mm}$ ), posicionamento da barra em relação ao tubo (centralizado ou excêntrico), cobrimento $(9,5 \mathrm{~mm}$ ou $11 \mathrm{~mm}$ ) e comprimento de ancoragem (100 mm ou $200 \mathrm{~mm}$ ).

\subsubsection{Influência do carregamento}

Para analisar a influência do carregamento foram ensaiadas emendas com as mesmas dimensões, mas com diferença no carregamento: monotônico ou cíclico.

A Figura 4.60 ilustra o comportamento da curva força $\mathrm{x}$ deslizamento para as emendas 45T16EC9.5-200 e 45T16CC9.5-200.

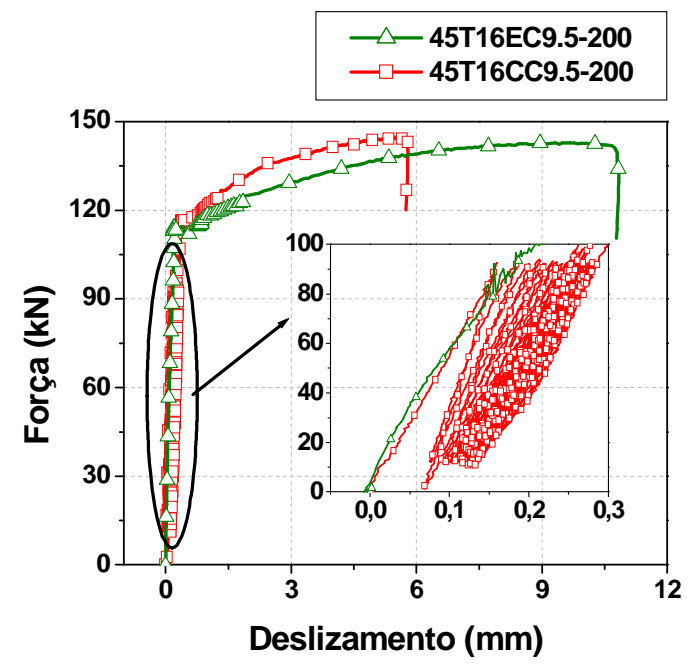

Figura 4.60 - Curvas força-deslizamento da média das emendas 45T16EC9.5-200 e 45T16CC9.5-

200

Observa-se na Figura 4.60 um comportamento similar entre as emendas. A emenda com carregamento cíclico apresentou um deslizamento residual, mas não houve diferença significante na força última atingida. O trecho linear corresponde à adesão entre os elementos e o curvo corresponde ao trecho de atrito mecânico. Independente do carregamento a que a emenda está sendo submetida, ocorreu o mesmo modo de ruptura e o mesmo valor de força última.

O carregamento não apresentou influência significante, visto que a sua alteração acarretaram na mesma ruína e capacidade resistente carga das emendas. 


\subsubsection{Influência do diâmetro da barra}

Para analisar a influência do diâmetro da barra foram comparadas emendas com as mesmas características, apenas alterando o diâmetro da barra (16 mm e $20 \mathrm{~mm}$ ). Ao se alterar o diâmetro da barra, o cobrimento foi alterado, pois neste caso, ao contrário do ensaio piloto, o diâmetro do tubo permaneceu constante entre as emendas.

A Figura 4.61 ilustra o comportamento das curvas tensão axial vs. deslizamento e tensão de aderência vs. deslizamento, respectivamente, para as emendas 50T16EC11-200 e 50T20EC9.5-200.
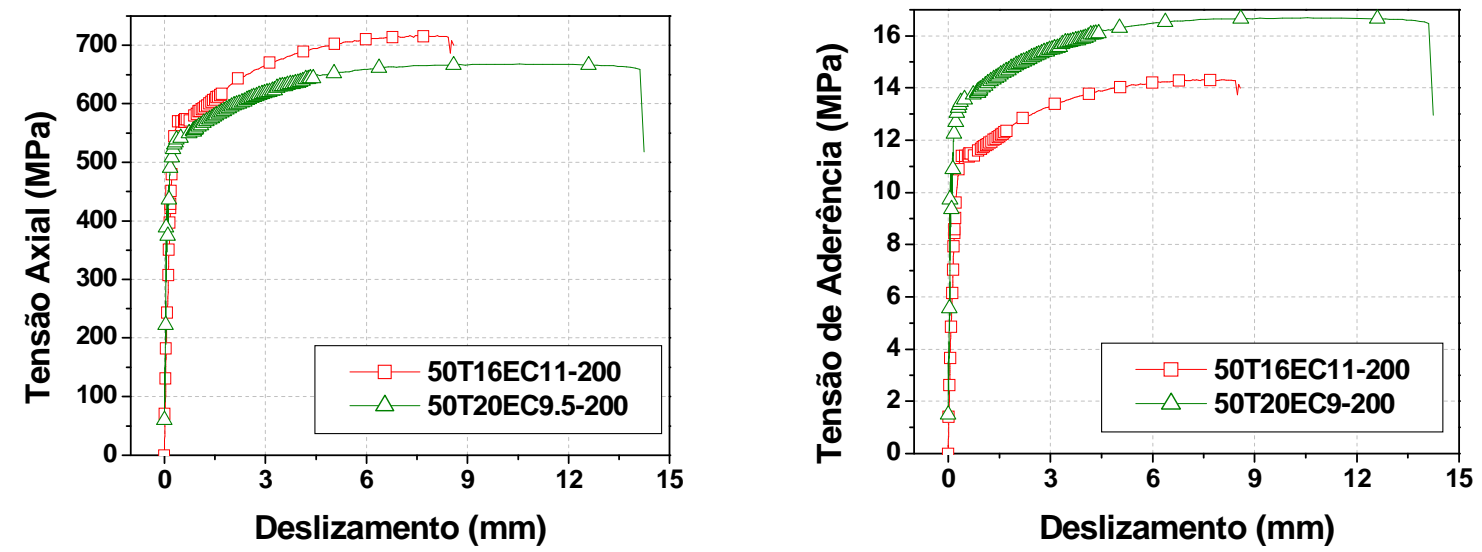

Figura 4.61 - Curva tensão-deslizamento e tensão de aderência-deslizamento das emendas 50T16EC11-200 e 50T20EC9.5-200

Como as emendas atingiram a ruína por escoamento da barra de aço, a emenda funcionou de forma monilítica, como um único elemento, de comportamento parecido com o do aço. Por isso, observa-se na Figura 4.61 que com o aumento do diâmetro da barra, houve aumento da tensão de aderência, enquanto que a tensão axial última foi praticamente a mesma, que é a do aço CA-50.

\subsubsection{Influência do posicionamento da barra}

Para analisar a influência do posicionamento da barra em relação ao tubo foram ensaiados tubos com as mesmas dimensões, mas com diferença neste posicionamento: centralizada e excêntrica.

A Figura 4.62 ilustra o comportamento da curva força vs.deslizamento para as emendas 45T16EC9.5-200 e 45T16EE-200. 


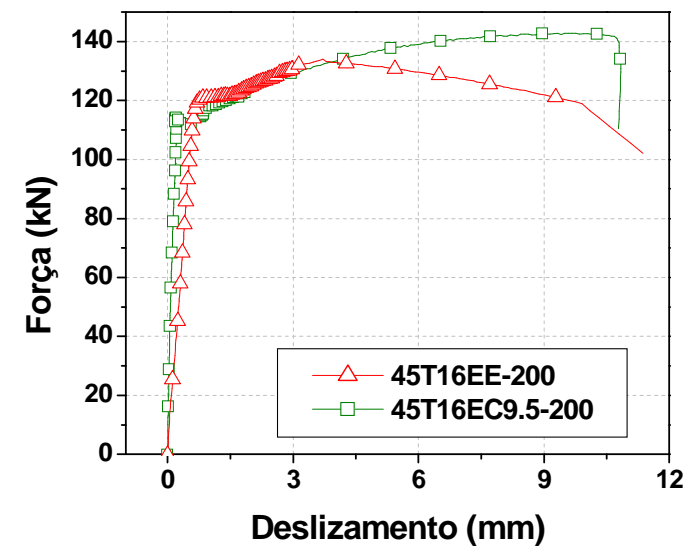

Figura 4.62 - Curvas força-deslizamento da média das emendas 45T16EC9.5-200 e 45T16EE-200

Observa-se na Figura 4.62 um comportamento similar entre as emendas independente do posicionamento da barra, com mesmo modo de ruína e atingindo mesma força última.

Percebe-se a irrelevância do posicionamento da barra, visto que obtiveram o mesmo comportamento e capacidade de carga, despreocupando com relação às falhas de execução relacionadas a este posicionamento.

\subsubsection{Influência do cobrimento}

Foram ensaiadas emendas com as mesmas dimensões e características, mas com diferença no cobrimento: $9,5 \mathrm{~mm}$ ou $11 \mathrm{~mm}$, para analisar a sua influência no desempenho da emenda.

A Figura 4.63 ilustra o comportamento da curva força $\mathrm{x}$ deslizamento para as emendas 45T16EC9.5-200 e 50T16EC11-200.

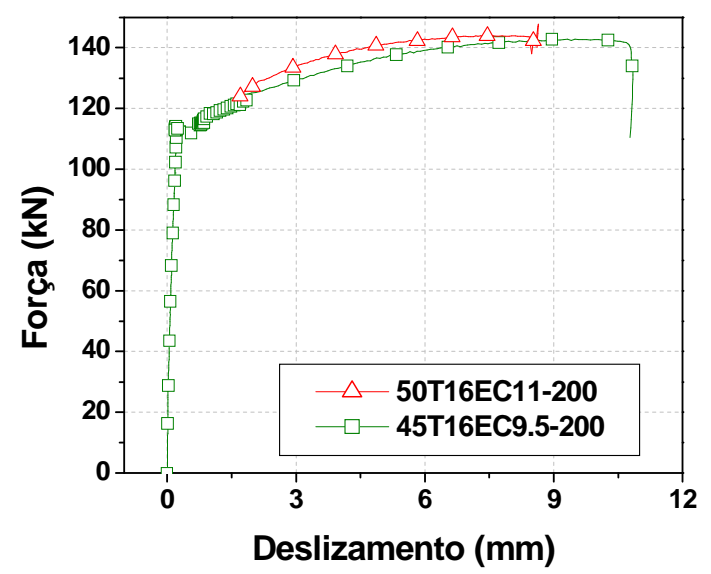

Figura 4.63 - Curva força-deslizamento da média das emendas 45T16EC9.5-200 e 50T16EC11-200 
Observa-se na Figura 4.63 um comportamento similar entre as emendas independente do cobrimento da barra, com mesmo modo de ruína e atingindo mesma força última.

O cobrimento não apresentou influência significante, visto que, com a sua alteração, as emendas obtiveram o mesmo comportamento, ruína e capacidade de carga.

\subsubsection{Influência do comprimento de ancoragem}

Foram ensaiadas emendas com as mesmas dimensões e características, mas com diferença no comprimento de ancoragem: $100 \mathrm{~mm}$ ou $200 \mathrm{~mm}$, para analisar a sua influência no desempenho da emenda.

A Figura 4.64 ilustra o comportamento das curvas força vs. deslizamento, tensão axial vs. deslizamento e tensão de aderência vs. deslizamento, respectivamente, para as emendas 45T16EC9.5-100 e 45T16EC9.5-200.
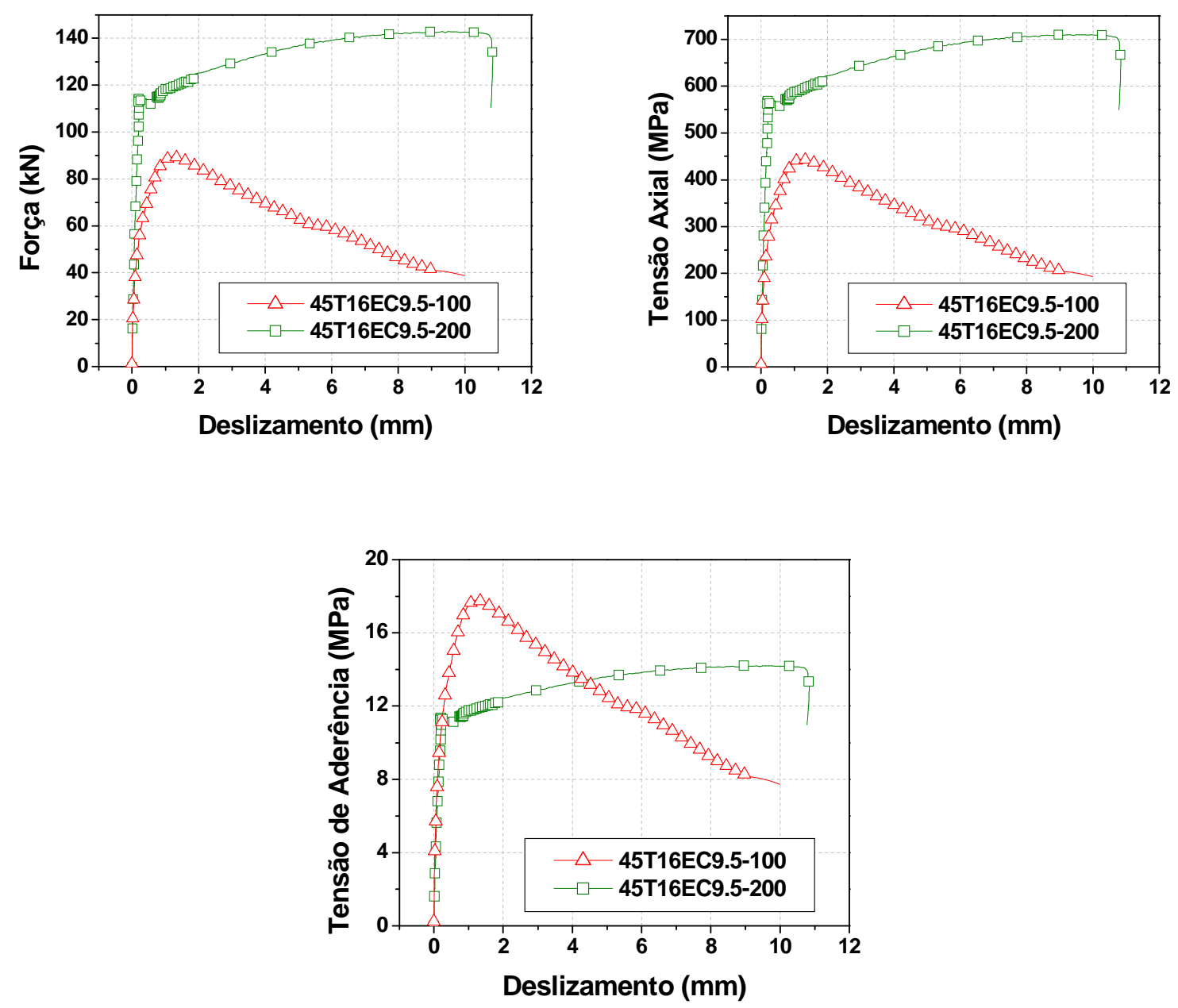

Figura 4.64 - Curvas força-deslizamento das emendas 45T16EC9.5-100 e 45T16EC9.5-200 
Observa-se na Figura 4.64 que com o aumento do comprimento de ancoragem há um aumento da capacidade de força e da tensão axial da emenda. Com relação à tensão de aderência, a emenda com menor comprimento de ancoragem, obteve maior tensão de aderência, isto porque esta emenda rompeu exatamente na aderência entre o tubo e o graute, atingindo, portanto, a capacidade máxima resistente de aderência, enquanto que a outra emenda rompeu por escoamento da barra de aço, não sendo solicitada toda a sua capacidade de aderência entre o graute e a barra.

A partir disto constata-se que pode haver um comprimento ótimo entre 100 e 200 $\mathrm{mm}$, para esta emenda com barra e tubos com diâmetros e rugosidade como a especificada para estas emendas, que solicitará o máximo da capacidade resistente de aderência entre o graute e a barra, mas romperá na barra, atingindo a capacidade máxima da emenda.

Com isso observa-se a relevância do comprimento de ancoragem, pois o mesmo está diretamente relacionado com a capacidade resistente da emenda e consequentemente com seu modo de ruína. 


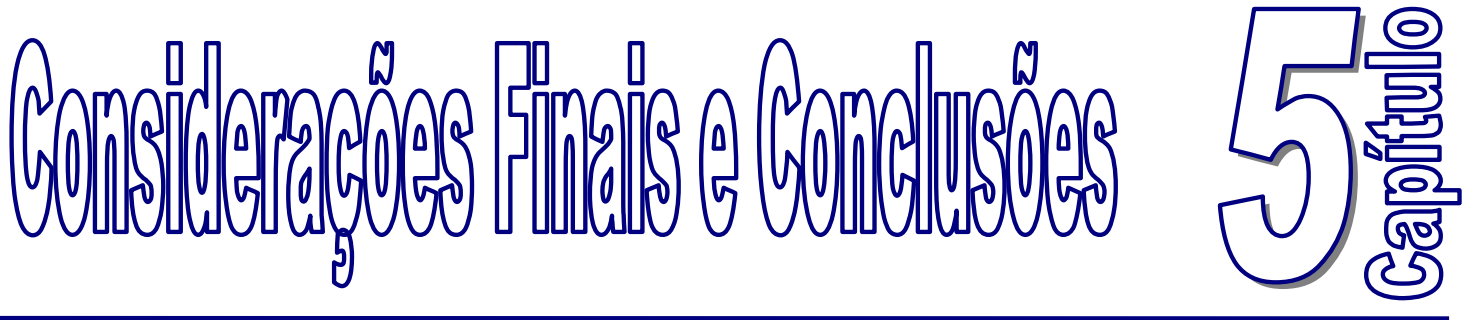

Este capítulo apresenta as conclusões do trabalho, bem como as sugestões para pesquisas futuras, tendo como objetivo o maior entendimento do comportamento da emenda estudada.

\subsection{Conclusões}

A partir dos resultados foi constatada a influência dos parâmetros variados neste trabalho:

a) Com relação ao comprimento de embutimento, observou-se relação direta com o seu aumento e o aumento da capacidade de carga da emenda. Ao se variar este parâmetro, verificou-se que um comprimento de embutimento de $6,25 \varnothing$ foi insuficiente para se obter a capacidade resistente da emenda, pois a mesma apresentou ruína da aderência entre a barra de aço e o graute, não apresentando um comportamento de aderência satisfatório. Enquanto que as emendas com comprimento de embutimento maior ou igual a $10 \varnothing$ atingiram a capacidade resistente, pois apresentaram ruína por escoamento da barra de aço;

b) Ao se variar o diâmetro da barra de aço, observou-se um aumento da tensão de aderência com o aumento do diâmetro, pois a capacidade foi maior;

c) O cobrimento, neste estudo, apresentou influência pouco significativa, onde emendas com cobrimento de $9,5 \mathrm{~cm}$ e $11 \mathrm{~cm}$ atingiram a capacidade resistente da emenda e apresentaram ruína por escoamento da barra de aço;

d) Não foi constatada redução da resistência da emenda nem alteração do seu modo de ruína devido ao posicionamento da barra de aço dentro do tubo, centralizada 
ou excêntrica, sendo atingida a capacidade máxima da emenda e a ruína por escoamento da barra de aço. Portanto, este tipo de emenda apresenta boas características construtivas devido às tolerâncias de montagem e execução. Já com relação às tensões ao longo da emenda, foram constatadas na emenda excêntrica tensões maiores na região do tubo onde a barra de aço estava encostada no mesmo, ocasionadas pela transferência dos esforços, mais diretamente, da barra de aço ao tubo, sendo, portanto uma parcela maior da tensão transferida, do que a tensão que era transferida da barra ao graute e do graute, finalmente ao tubo nas outras regiões do tubo;

e) Quanto ao tipo de carregamento solicitado, não foi constatada redução da resistência da emenda nem alteração do seu modo de ruína devido ao carregamento cíclico em relação ao carregamento estático, pois foi atingida a capacidade máxima da emenda e a ruína por escoamento da barra de aço, apresentando um bom desempenho sob este carregamento dinâmico;

f) A emenda ensaiada correspondia a duas emendas, sendo uma extremidade submetida diretamente ao carregamento e a outra submetida à reação deste carregamento, mas não houve relação observada entre a extremidade onde ocorreu a ruína e a extremidade submetida ao carregamento ou à reação;

g) Para que o grauteamento ocorresse na direção horizontal, simulando uma situação em obra, foi necessário fazer um furo em uma extremidade do tubo. Não foi observada relação entre a extremidade onde ocorreu a ruína e a extremidade que possuía o furo no tubo de aço, pois as tensões neste ponto do tubo eram baixas. Além disso, não foi observada alteração no modo de ruína e na capacidade de carga devido à presença do furo na emenda. Apesar disso, houve um pouco de perturbação nas tensões próximas a este furo, que foi captada pelo extensômetro mais próximo deste;

h) A direção do grauteamento não influenciou no modo de ruína nem na capacidade de carga da emenda, sendo atingido os mesmos tanto para o grauteamento na vertical, ou seja, na mesma direção do carregamento, como na direção horizontal, ou seja, na direção perpendicular ao carregamento;

i) Nas emendas que romperam por escoamento da barra de aço, foi constatado o aparecimento de fissuras no graute e descolamento de alguns pedaços do mesmo, devido ao seu fendilhamento, apesar do confinamento existente, mas que não acarretaram na ruína da emenda;

j) A partir dos resultados dos extensômetros nos ensaios, observou-se pouca solicitação do tubo, principalmente no seu sentido circunferencial, onde foi praticamente nula. 
Com isso observa-se para a emenda estudada grande relevância para o seu comportamento o diâmetro da barra de aço e o comprimento de embutimento. Enquanto que o tipo de carregamento, o cobrimento, o posicionamento da barra de aço dentro do tubo e a presença do furo para grauteamento do tubo apresentam influência pouco significativa no desempenho desta emenda quanto ao modo de ruína observado e a capacidade de carga atingida.

\subsection{Propostas para pesquisas futuras}

Como sugestões para pesquisas futuras, se propõem:

- Desenvolver um modelo numérico com critério de ruína, com a finalidade de se obter melhor aproximação em relação aos resultados experimentais e calibrar a modelagem numérica com a pesquisa experimental;

- Realização de ensaios de emendas com grautes de diferentes resistências à compressão, com o objetivo de avaliar a influência do tipo de graute no comportamento da emenda;

- Desenvolver um graute para esta emenda que possua alta resistência inicial e final, alta aderência, compacidade e fluidez, e pequena retração para com isso garantir a transmissão das forças do tubo à barra de aço;

- Realização de ensaios de emendas com tubos de diferentes conformações superficiais, com o objetivo de avaliar a influência da conformação superficial do tubo no comportamento da emenda;

- Realização de ensaios da emenda em vigas, para melhor representação do comportamento real de estruturas submetidas à ação de momento fletor, e posterior comparação dos resultados com as emendas isoladamente;

- Realização de ensaios de emendas sob ação cíclica com aplicação de certa amplitude de força até a ruína do modelo, com o objetivo de avaliar a influência deste tipo de carregamento sob o comportamento da emenda e a sua capacidade resistente sob ações dinâmicas. 


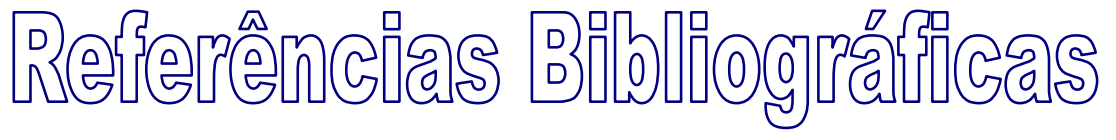

ALMEIDA FILHO, F. M (2006). "Contribuição ao estudo da aderência entre barras de aço e concretos auto-adensáveis". 292p.Tese (Doutorado) - Escola de Engenharia de São Carlos, Universidade de São Paulo, São Carlos. 2006.

ASSOCIAÇÃO BRASILEIRA DE NORMAS TÉCNICAS (1980), "NBR 5739:1980 - Ensaio de compressão de corpos-de-prova cilíndricos de concreto", Rio de Janeiro, RJ, Brasil.

ASSOCIAÇÃO BRASILEIRA DE NORMAS TÉCNICAS (1983), "NBR 7222:1983 Argamassas e concretos - determinação da resistência à tração por compressão diametral de corpos-de-prova cilíndricos", Rio de Janeiro, RJ, Brasil.

ASSOCIAÇÃO BRASILEIRA DE NORMAS TÉCNICAS (1984), "NBR 8522:1984 - Concreto - determinação do módulo de deformação estática e diagrama tensão x deformação", Rio de Janeiro, RJ, Brasil.

ASSOSIAÇÃO BRASILEIRA DE NORMAS TÉCNICAS (1992). "NBR 6152:1992 - Materiais Metálicos - determinação das propriedades mecânicas à tração - Método de ensaio", Rio de Janeiro, RJ, Brasil.

ASSOSIAÇÃO BRASILEIRA DE NORMAS TÉCNICAS (1996). "NBR 7480:1996 - Barras e fios de aço destinadas a armaduras para concreto armado", Rio de Janeiro, RJ, Brasil.

ASSOCIAÇÃO BRASILEIRA DE NORMAS TÉCNICAS (2003), "NBR 6118:2003 - Projeto de estruturas de concreto", Rio de Janeiro, RJ, Brasil.

BALDISSERA, A., "Estudo experimental de uma ligação viga-pilar de concreto pré-moldado parcialmente resistente a momento fletor", Dissertação (Mestrado), Escola de Engenharia de São Carlos, Universidade de São Paulo, São Carlos, SP. 2006. 149p.

BARBOSA, M. T. G. (2001), "Avaliação do comportamento da aderência em concretos de diferentes classes de resistência", Tese de Doutorado, UFRJ - COPE, Rio de Janeiro, RJ. $187 p$.

BARBOSA, M. T. G. et al. (2000), "Estudo da influência do diâmetro da barra e da resistência à compressão do concreto no ensaio de pull out para determinação da tensão última de aderência". In: IV Congresso de Engenharia Civil, v. 1, p. 435-464, Juiz de Fora, MG, Brasil. 
BARBOZA, A. S. R. (2001). "Comportamento de juntas de argamassa solicitadas à compressão na ligação entre elementos pré-moldados". 143p. Tese (Doutorado) - Escola de engenharia de São Carlos, Universidade de São Paulo, São Carlos. 2001.

CANHA, R. M. F., "Estudo teórico-experimental da ligação pilar-fundação por meio de cálice em estruturas de concreto pré-moldado", tese (doutorado), São Carlos, EESC-USP, 2004.

CHEOK, G.S.; LEW, H.S. (1991). "Performance of precast concrete beam-to-column connections subject to cyclic loading". PCl journal precast/prestressed concrete institute, v.36, n. 3, p. 56-67, May-June.

COMITE EURO-INTERNATIONAL DU BETON (1982) "Bond action and bond behavior of reinforcement: state-of-the-art report", Bulletin d'Information, n. 151.

COMITE EURO-INTERNATIONAL DU BETON (1990). "CEB-FIP Model Code for Concrete Structures". Paris: CEB, 1991. Bulletin d'Information 203.

EINEA, A., YAMANE, T., TADROS, M. K., "Grout-Filled Pipe Splices for Precast Concrete Construction", PCl Journal, Volume 40, No.1, January-February,1995, pp. 82-93;

EINEA, A., YEHIA, S., TADROS, M. K., "Lap splices in confined concrete", ACI Structural Journal, V.96, nº 6, p. 947-955, November-December 1999.

EL DEBS, M.K. (2000). "Concreto pré-moldado: Fundamentos e aplicações". 1.ed. São Carlos, EESC-USP, 441p.

ELIGEHAUSEN, R.; POPOV, E. P.; BERTERO, V. V. (1983). Local bond stress-slip relationships of deformed bars under generalized excitations. Report no UCB/EERC- 83/23, University of California, Berkeley.

ELLIOTT, K.S. et al. (2003). "Can precast concrete structures be designed as semi-rigid frames?". Structural engineer, v.81, n.16, p. 14-37, August.

ENGLEKIRK, R. E. (1995). "Development and testing of a ductile connector for assembling precast concrete beams and columns". $\mathrm{PCl}$ journal precast/prestressed concrete institute, v.40. n 2.p 36-51.

FEDERATION INTERNATIONALE DU BETON (2003) "FIB 9.3 TG - FRP as reinforcement in concrete", (Proposta de norma), Sheffield, Inglaterra.

FERNANDES, R. M. (2000), "Influência das Ações Repetidas na Aderência Aço-Concreto", Dissertação (Mestrado), EESC, São Carlos, SP, Brasil.

FERREIRA, M.A. (1999). " Deformabilidade de ligações viga-pilar de concreto pré-moldado". 232p. Tese (Doutorado) - Escola de engenharia de São Carlos, Universidade de São Paulo, São Carlos. 1999.

FUSCO, P. B.(1976), "Estrutura de Concreto - Fundamentos do Concreto Estrutural", Editora da Universidade de São Paulo e Ed. McGraw-hill, São Paulo, SP, Brasil. 298p.

FUSCO, P. B.(1995), "Técnica de Armar as Estruturas de Concreto", PINI Editora, São Paulo, SP, Brasil.

HELENE, P. R. L., "Manual para reparo, reforço e proteção de estruturas de concreto", $2^{\mathrm{a}}$ ed., São Paulo: Pini ,1992. 
KERONEN, A. (1996). "Effect of semi-rigid connections in rc portal frame: Load tests".Report of Tampare University of Technology, Finlândia. p 95.

KUTTAB, A., DOUGILL, J. W., "Grouted and dowelled jointed precast concrete columns: behavior in combined bending and compression", Magazine of concrete research, sep. 1998.

LEONHARDT, F.; MÖNNIG, E. (1977), "Construções de Concreto: Princípios Básicos do Dimensionamento de Estruturas de Concreto Armado" Interciência, v. 1, Rio de Janeiro, RJ, Brasil.

LOHAUS, L., ANDERS, S., "Static and fatigue behaviour of high-performance concrete in "grouted joints" for hybrid structures", Proceedings of the $2^{\text {nd }}$ fib International Congress, Itália, 2006.

MEHTA, P. K., MONTEIRO, P. J. M., "Concreto: estrutura, propriedades e materiais", $1^{\text {a }}$ ed., São Paulo: Pini, 1994;

MIOTTO, A.M. (2002). "Ligações viga-pilar de estruturas de concreto pré-moldado: Análise com ênfase na deformabilidade ao momento fletor". 234p. Tese (Doutorado) - Escola de engenharia de São Carlos, Universidade de São Paulo, São Carlos. 2002.

MOOSAVI, M., JAFARI, A., KHOSRAVI, A., "Bond of cement grouted reinforcing bars under constant radial pressure", Cement \& Concrete Composites, n. 27, p. 103-109. 2005

DE NARDIN, S., "Estudo teórico-experimental de pilares mistos compostos por tubos de aço preenchidos com concreto de alta resistência", São Carlos, 1999. 148p. Dissertação (mestrado) - Escola de Engenharia de São Carlos, Universidade de São Paulo.

REHM, G.; ELIGEHAUSEN, R. (1979), "Bond of ribbed bars under high cycle repeated loads", ACl Journal, Symposium Paper, n. 76-15, p. 297-309.

SOARES, A.M.M. (1998). "Análise estrutural de pórticos planos de elementos pré-fabricados de concreto considerando a deformabilidade das ligações". 178p. Dissertação (Mestrado) Escola de engenharia de São Carlos, Universidade de São Paulo, São Carlos. 1998.

SOROUSHIAN, P., CHOI, K., "Local bond of deformed bars with different diameters in confined concrete", ACI Structural Journal, V.86, no 2, p. 217-222, Mar-Apr. 1989.

SOROUSHIAN, P., CHOI, K., PARK, G., ASLANI, F., "Bond of deformed bars to concrete: effects of confinement and strength of concrete", $\mathrm{ACl}$ Materials Journal, V.88, $\mathrm{n}^{\circ} 3, \mathrm{p} .227-$ 232, May-June. 1991.

TEPFERS, R. (1979), "Cracking of Concrete cover along Anchored Deformed Reinforced Bars", Magazine of Concrete Research, v. 31, n. 106, p. 3-12.

VALLE, A., "Estudo da aderência entre concreto e armadura sob carregamento cílclico". 171p. Dissertação (Mestrado) - Escola Politécnica, Universidade de São Paulo, São Paulo. 1994.

ZHENG, L. "Grouted precast concrete column connections under reversed cyclic bending and compression", ACI Structural Journal, V.93, no 3, p. 247-256, May-June 1996. 
YAMADA, M., SUMI, A., KIMURA, H., MIYAUTCHI, Y., " The development of a new lap splice with headed anchor by gas pressure welding for precast beams", Proceedings of the 1st fib Congress, Japão, 2002.

YOSHITAKE, K., SHIOYA, T., KURITA, M., TANAKA, H., "New system for connecting precast concrete beams with performance cementitious composites", Proceedings of the 1st fib Congress, Japão, 2002. 